\title{
The Latent Architecture of the Abrahamic Faiths
}

\section{Mark W. Baechler, Dipl.Arch.Tech., B.Arch.S.}

\author{
A thesis submitted to the faculty of Graduate Studies and \\ Research in partial fulfillment of the requirements for the degree of \\ Master of Architecture (M.ARCH) Professional.
}

\footnotetext{
Carleton University, Ottawa, Ontario, Canada

Mark W. Baechler (C) 2006
} 


$\begin{array}{ll}\begin{array}{l}\text { Library and } \\ \text { Archives Canada }\end{array} & \begin{array}{l}\text { Bibliothèque et } \\ \text { Archives Canada }\end{array} \\ \begin{array}{l}\text { Published Heritage } \\ \text { Branch }\end{array} & \begin{array}{l}\text { Direction du } \\ \text { Patrimoine de l'édition }\end{array} \\ \begin{array}{l}\text { 395 Wellington Street } \\ \text { Ottawa ON K1A 0N4 } \\ \text { Canada }\end{array} & \begin{array}{l}\text { 395, rue Wellington } \\ \text { Ottawa ON K1A ON4 } \\ \text { Canada }\end{array}\end{array}$

Your file Votre référence ISBN: 978-0-494-23317-7 Our file Notre référence ISBN: 978-0-494-23317-7

NOTICE:

The author has granted a nonexclusive license allowing Library and Archives Canada to reproduce, publish, archive, preserve, conserve, communicate to the public by telecommunication or on the Internet, loan, distribute and sell theses worldwide, for commercial or noncommercial purposes, in microform, paper, electronic and/or any other formats.

The author retains copyright ownership and moral rights in this thesis. Neither the thesis nor substantial extracts from it may be printed or otherwise reproduced without the author's permission.
AVIS:

L'auteur a accordé une licence non exclusive permettant à la Bibliothèque et Archives Canada de reproduire, publier, archiver, sauvegarder, conserver, transmettre au public par télécommunication ou par l'Internet, prêter, distribuer et vendre des thèses partout dans le monde, à des fins commerciales ou autres, sur support microforme, papier, électronique et/ou autres formats.

L'auteur conserve la propriété du droit d'auteur et des droits moraux qui protège cette thèse. $\mathrm{Ni}$ la thèse ni des extraits substantiels de celle-ci ne doivent être imprimés ou autrement reproduits sans son autorisation.
In compliance with the Canadian

Privacy Act some supporting forms may have been removed from this thesis.

While these forms may be included in the document page count, their removal does not represent any loss of content from the thesis.
Conformément à la loi canadienne sur la protection de la vie privée, quelques formulaires secondaires ont été enlevés de cette thèse.

Bien que ces formulaires aient inclus dans la pagination, il n'y aura aucun contenu manquant.

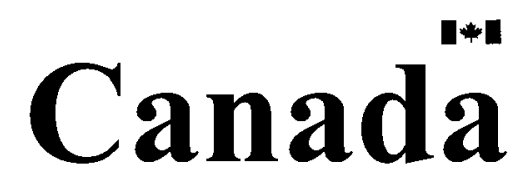




\section{Abstract}

As a means of designing Abrahamic architecture this thesis investigates the interconnections within the theological representation of Judaism, Christianity and Islam. Throughout the development of Abrahamic religions the theologies of the faiths have been rendered in numerous communicative mediums. The sacred texts are the most predominate form of representation and they serve most often as the authoritative foundation of its various counterparts. The literary composition of the Torah, New Testament and Qur'an are discussed to reveal the underlying interpretive framework of the texts which encouraged the translation of Abrahamic theology into increasingly more connotative forms of imagery and architecture. Interwoven compositions of imagery and architecture found within the early remnants of the faiths are discussed as Allegorical spaces which reveal the theological and material dimensions of the Abrahamic universe. It is the latent architecture found within the Allegorical imagery of the Abrahamic faiths that shapes the reality of the faithful and informs a design philosophy from which Abrahamic architecture emerges. 
The Lord bless you and keep you; the Lord make his face shine upon you and be gracious to you; the Lord turn his face toward you and give you peace. -Torah -Numbers 6:24-26

Understand, then, that those who believe are children of Abraham. The Scripture foresaw that God would justify the Gentiles by faith, and announced the gospel in advance to Abraham: "All nations will be blessed through you." So those who have faith are blessed along with Abraham, the man of faith. -New Testament -Galatians 3:7-9

In the creation of the heavens and the earth; in the alternation of the night and day; in the sailing of ships through the ocean for the benefit of mankind; in the water which Allah sends down from the sky and with which He revives the earth after its death, and dispersing over it all kinds of beasts; in the ordinance of the winds and clouds that are driven between earth and sky: are signs for people who understand. -Qur'an -Sura 2:164 


\section{Table of Contents}

List of Figures

List of Appendices

Introduction

1.0 Abrahamic Sacred Texts:

1.1 Northrop Frye: Language Framework 5

1.1.1 Poetic Language

1.1.2 Metonymic Language

1.1.3 Descriptive Language

1.2 Revelation Language

2.0 Allegory:

2.1 Torah -Numbers 20: 5-12 17

2.2 New Testament -Mark 4:3-20 19

2.3 Qur'an -Sura 2:26, Sura 24:35 22

3.0 Abrahamic Imagery: ................................................. 25

3.1 Jewish Imagery $\quad 25$

$\begin{array}{ll}3.2 \text { Christian Imagery } & 29\end{array}$

3.3 Islamic Imagery $\quad 36$

4.0 Allegorical Space: ....................................................... 42

4.1 The Latent Architecture of the Abrahamic Faiths 42

4.2 Dura-Europos Synagogue $\quad 43$

4.2.1 Allegorical Space of the Prayer Hall 52

$\begin{array}{ll}\text { 4.2.2 Representation of Allegorical Space } & 62\end{array}$

4.3 Dura-Europos House church 63

4.3.1 Allegorical Space of the Baptistery 66

4.3.2 Representation of Allegorical Space 66

$\begin{array}{ll}4.4 \mathrm{Ka} b a & 69\end{array}$

4.4.1 Allegorical space of the Ka'ba $\quad 73$

$\begin{array}{ll}\text { 4.4.2 Representation of Allegorical Space } & 74\end{array}$

5.0 Abrahamic Space: . ....................................................... 77

5.1 Abrahamic Theological Space $\quad 77$

5.2 Santa Maria la Blanca (Saint Mary the White) Synagogue/ Church 78

and Transito (or Prince's) Synagogue/ Church

5.3 El Cristo de la Luz (Christ of the light) Mosque/ Church 84

5.4 Ayasofya (Hagia Sophia) Church/ Mosque 86

6.0 Abrahamic Architecture: . ................................................... 102

$\begin{array}{ll}\text { 6.1 Mar Elias University } & 102\end{array}$

6.2 Architectural Representation of Abrahamic Allegorical Space 107

$\begin{array}{lr}\text { Appendices } & 120\end{array}$

Bibliography $\quad 158$ 


\section{List of Figures}

\section{Figure Number: Description:}

1

2

3

4

5

6

7

8

9

10

11

12
The Well of the Wilderness: Moses Gives Water to the Twelve Tribes. Image from Jewish Symbols in the Greco-Roman Period. Erwin R. Goodenough, (New York: Bollingen Foundation, 1964).

Imagery of the Callistus Catacomb. Image from The Invisible God. Paul Finney, (New York: Oxford University Press, 1994).

Moses Receiving the Law. Image from Early Medieval Bible Illumination and the Ashburnham Pentateuch. Dorothy Verkerk, (Cambridge:

Cambridge University Press, 2004).

Kufic Calligraphy Illumination of Sura 1, or "The Opening". Image from Islamic Art and Spirituality. Seyyed Hossein Nasr, (Albany: State University of New York Press, 1987).

Qur'anic Revelation within Dome at the Alhambra, Granada, Spain. (M. Baechler).

Dura-Europos Arial Image and Archeological Urban Plan. Image from Dura-Europos and its Art. M. Rostovtzeff, (Oxford: Clarendon Press, 1938).

Excavation of Dura-Europos Synagogue. Images from The Synagogue. Carl H. Kraeling, (New Haven: Yale University Press, 1979).

Urban Block Plan of the Dura-Europos Synagogue. Image from The Synagogue. Carl H. Kraeling, (New Haven: Yale University Press, 1979).

Reconstructed Plan of First Renovation and Field Plan of the DuraEuropos Synagogue. Images from The Synagogue. By Carl H. Kraeling, (New Haven: Yale University Press, 1979).

Reconstructed Plan of Second Renovation of the Dura-Europos Synagogue. Image from The Synagogue. Carl H. Kraeling, (New Haven: Yale University Press, 1979).

Reconstructed Sections of First and Second Renovation of the DuraEuropos Synagogue. Images from The Synagogue. Carl H. Kraeling, (New Haven: Yale University Press, 1979).

Aedicula and Torah niche of the Dura-Europos Synagogue. Image from The Synagogue. Carl H. Kraeling, (New Haven: Yale University Press, 1979). 
Allegorical Imagery of the Dura-Europos Synagogue. Image from Jewish Symbols in the Greco-Roman Period. Erwin R. Goodenough, (New York: Bollingen Foundation, 1964).

Reconstructed Image of the Tree of Life. Image from The Synagogue. Carl H. Kraeling, (New Haven: Yale University Press, 1979).

Moses, Abraham and Samuel. Image from Jewish Symbols in the GrecoRoman Period. Erwin R. Goodenough, (New York: Bollingen Foundation, 1964).

Aaron and the priests at the Temple or Tabernacle. Image from Jewish Symbols in the Greco-Roman Period. Erwin R. Goodenough, (New York: Bollingen Foundation, 1964).

Moses Discovered in the Nile River. Image from Jewish Symbols in the Greco-Roman Period. Erwin R. Goodenough, (New York: Bollingen Foundation, 1964).

Allegorical Space of the Dura-Europos Synogogue. (M. Baechler).

Reconstructed Plan of original Dura House and First Renovation Plan of the Dura-Europos House Church. Images from The Social Origins of Christian Architecture. Michael White, (Valley Forge: Trinity Press International, 1990).

Jesus and his Disciples at the Sea of Galilee. Image from Dura-Europos and its Art. M. Rostovtzeff, (Oxford: Clarendon Press, 1938).

Allegorical Space of the Dura-Europos House Church. (M. Baechler).

Ka'ba, Makkah. (Ozayr S. Saloojee).

Allegorical Space of the Ka'ba. (M. Baechler). Santa Maria la Blanca (Saint Mary the White) Synagogue/ Church. (M. Baechler)

Islamic Imagery within the Santa Maria la Blanca (Saint Mary the White) Synagogue/ Church. (Toledo: Actas del Congreso Internacional, 1999). the White) Synagogue/ Church. (M. Baechler). 
Islamic and Jewish Imagery within the Transito (or Prince's) Synagogue/ Church. (M.Baechler).

Vaulted Domes within the Cristo de la Luz (Christ of the light) Mosque/ Church, Toledo, Spain. (M. Baechler).

Vaulted Dome within the Cordoba Mosque/ Church. (M. Baechler).

Vaulted Dome within the Cordoba Mosque/ Church. (M. Baechler).

Plan and Reflected Ceiling Plan of Cristo de la Luz (Christ of the light) Mosque/ Church. (M. Baechler).

Section and Reflected Ceiling of Cristo de la Luz (Christ of the light) Mosque/ Church. (Source of image unknown). (Dominique Halbout Du Tanney, Istanbul: Dost Yayinlari, 1996).

Image of Istanbul. Image from Istanbul Seen By Matrajci. (Dominique Halbout Du Tanney, Istanbul: Dost Yayinlari, 1996).

Ayasofya (Saint Sophia) Church/Mosque, Istanbul, Turkey. (M. Baechler).

Image of Ayasofya (Saint Sophia) Church/ Mosque. Image from Istanbul Seen By Matrajci. (Dominique Halbout Du Tanney, Istanbul: Dost Yayinlari, 1996). Interior of Ayasofya (Saint Sophia) Church/ Mosque. Image from Hagia Spohia. (Fatih Cimok, Istanbul: A Turizm Yayinlari, 1995). Byzantine Churches in Istanbul. (Suleyman Kirimtayif, Istanbul: Ege Yayinlari, 2001).

Allegorical Imagery within Ayasofya (Saint Sophia) Church/Mosque. (M.Baechler).

Ibillin, Israel. (Google Earth) Proposed Site of Mar Elias University. (M. Baechler). 
45

46

47

48

49

$50-56$
Architecture and Landscape of Mar Elias Educational Institution. (M. Baechler).

Allegorical Representations of Moses Receiving the Law. (M. Baechler)

Allegorical Representation of the Tabernacle. (M. Baechler)

Allegorical Representation of the Abrahamic Universe. (M. Baechler)

Abrahamic Allegorical Theological/ Architectural Image. (M. Baechler)

Allegorical Space of the Mar Elias University. (M. Baechler) 


\section{List of Appendices}

\section{Appendix:}

A

B

C

\section{Description:}

Summery of the books of the Torah (Exodus, Leviticus, Numbers, Deuteronomy, Joshua, Judges, Ruth, 1 Samuel, 2 Samuel, 1 Kings, 2Kings, 1 Chronicles, 2 Chronicles, Ezra, Nehemiah, Esther, Job, Psalms, Proverbs, Ecclesiastes, Song of Solomon, Isaiah, Jeremiah, Lamentations, Ezekiel, Daniel, Hosea, Joel, Amos, Obadiah, Jonah, Micah, Nahum, Habakkuk, Zephaniah, Haggai, Zechariah, Malachi) with references to New Testament and Qur'an noted.

Summery of the books of the New Testament (Matthew, Mark, Luke, John, Acts (of the Apostles), Romans, 1 Corinthians, 2 Corinthians, Galatians, Ephesians, Philippians, Colossians, 1 Thessalonians, 2 Thessalonians) with references to Torah and Qur'an noted.

Summery of the Suras of the Qur'an (Al-Fatiha The Opening, Al-Baqara The Cow) with references to Torah and New Testament noted. 


\section{Introduction}

Despite their common origins and similar theologies, the religious traditions of Judaism, Christianity and Islam often appear disconnected. This fragmented portrait of the Abrahamic faiths is drawn from a history of misunderstanding, misrepresentation and political difference. Unfortunately, the disjunction that exists among the Abrahamic Faiths has created violent conflict that is increasingly prevalent today. This violence often overshadows any opportunity to reflect on the common origin shared by the children of Abraham. The Arab village of Ibillin formed the Mar Elias Educational Institution in an effort to mend Jewish, Christian and Muslim relations through worship and education. This institution is in the process of attaining university status and, with this distinction, will require an architectural presence. This thesis investigates interconnections within the theological representation of the Abrahamic faiths as a means to generate an Abrahamic architecture for Mar Elias University.

For Believers, the sacred texts of the Abrahamic faiths are understood as divine revelation. Historical and archeological evidence suggests that at various times the Scriptures were adorned with imagery and further that these images were also used in the decoration of architectural spaces to create what I have interpreted as allegorical space. The Dura-Europos synagogue, housechurch, and the Ka'ba are among the earliest known architectural artifacts of the Abrahamic traditions. Originally conceived outside of the Abrahamic traditions, these buildings were spatially adapted, in part, through the use of imagery. I argue that the combined space/image of these early spaces of prayer is intended to reveal to believers a new world created by God for the faithful. The allegorical space found within all of the Abrahamic traditions is considered here as the locus for an 
architecture of reconciliation-an Abrahamic architecture that speaks to Jews, Christians, and Muslims.

In summary, I argue that within the early space/image of the Abrahamic faiths there exists a latent architecture. These allegorical spaces can be translated through architectural drawings and they can reveal the substance of an Abrahamic architecture. Allegorical space is understood as a hermeneutic form of representation that results when architecture and the ephemeral dimensions of allegorical imagery fuse. Allegorical space houses the Word of God and has the capacity to reconcile the divided realms of the Abrahamic universe. 

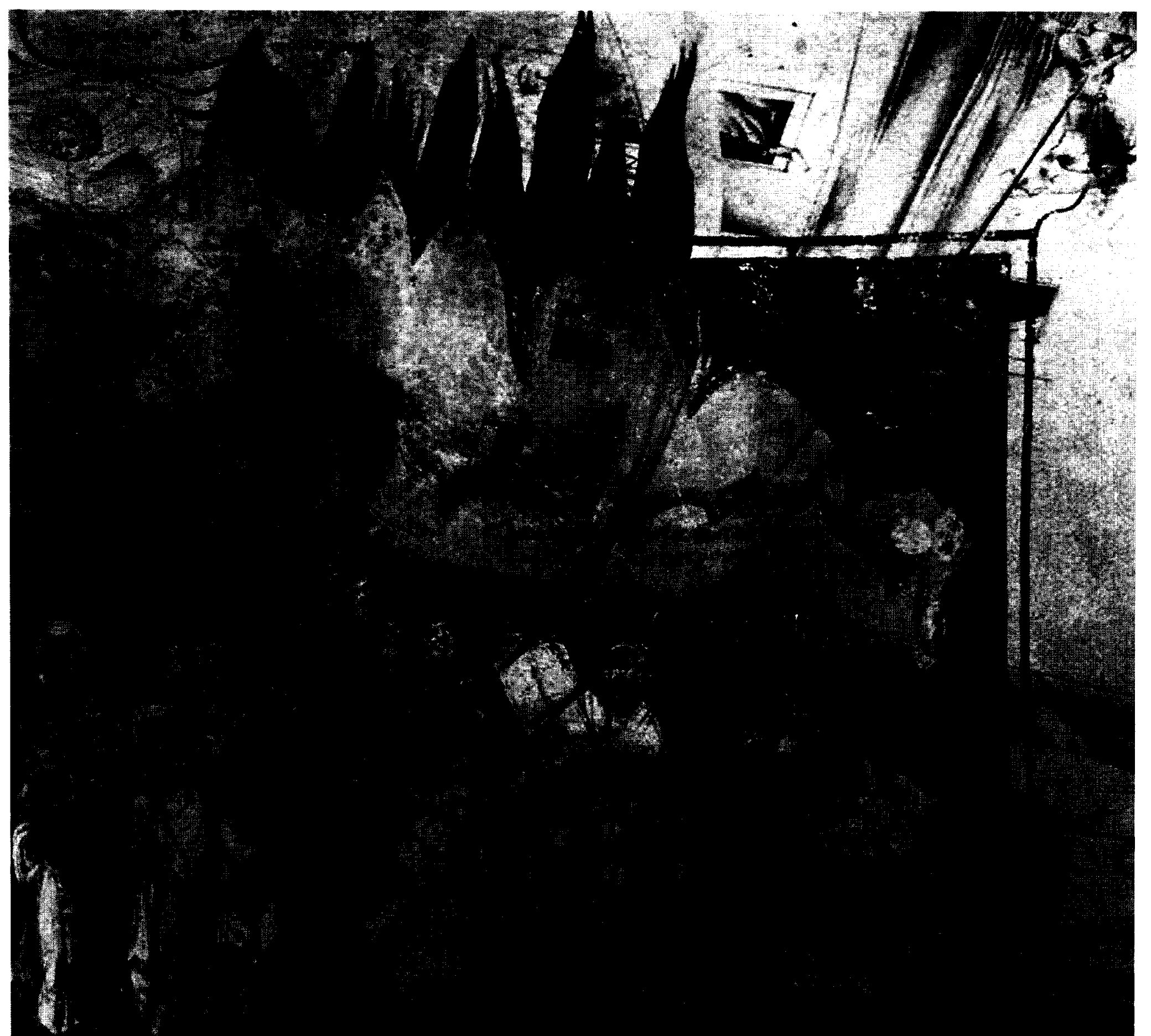

\subsection{Abrahamic Sacred Texts}

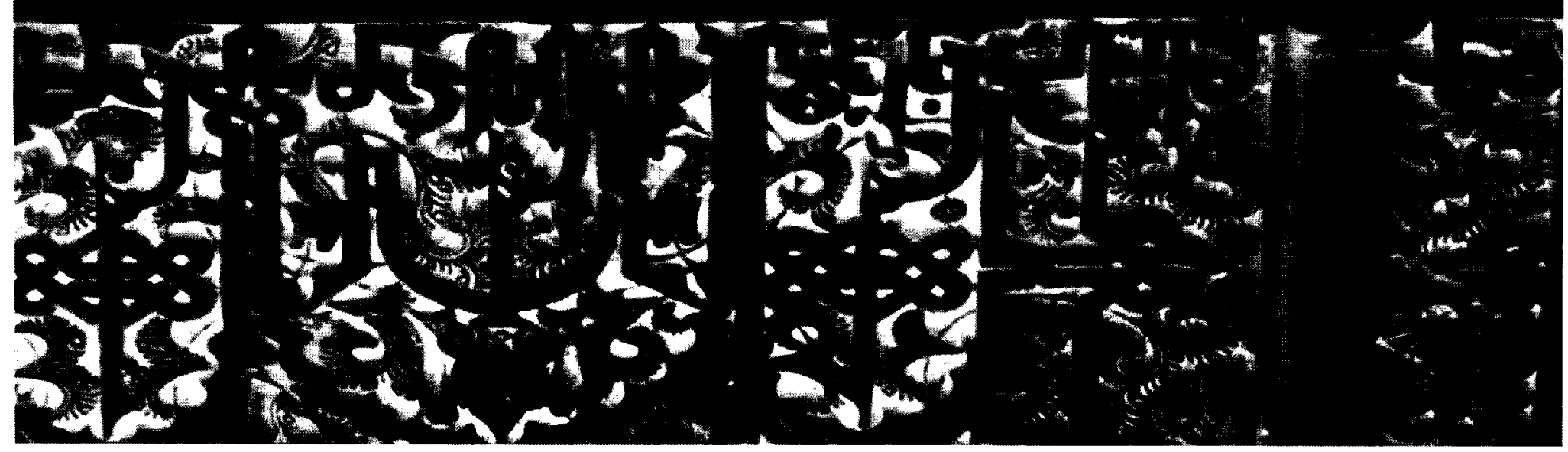




\subsection{Abrahamic Sacred Texts:}

Man lives, not directly in nature like animals, but within a mythological universe, a body of assumptions and beliefs developed from his existential concerns. Most of this is held unconsciously, which means our imaginations may recognize elements of it, when presented in art or literature, without consciously understanding what it is that we recognize. -Northrop Frye ${ }^{1}$

To follow Northrop Frye, in the tradition of Western thought, the mythological universe is given form by the sacred texts of the Abrahamic faiths. The Torah², the Christian Bible, and the Qur'an are poetic texts composed of allegories, dreams, parables, revelations and ancient events. Collectively, the sacred texts reveal the God of Abraham, who is believed by Jews, Christians and Muslims to be the one true God who resides in heaven and gave shape to all existence. Although referred to by three different names, the Abrahamic God unifies Judaism, Christianity and Islam. The Abrahamic God is believed to be the sole reason for human existence and is therefore the only entity deserving of human worship. The sacred texts of the Abrahamic tradition render a world in the imaginations of the faithful where they are surrounded and embraced by the presence of God. The texts serve as a sort of moral and geographical map which allows Jews, Christians and Muslims to navigate the emotional and physical terrain of their mythological universe.

The Abrahamic sacred texts each have their own distinct histories and were compiled by numerous authors at different times. Despite the geography and time that separate the sacred texts, their language and content draws them together and renders an infinitely unfolding portrait of the Abrahamic universe. The sacred texts are all believed to house the revelation of God, and they are written in a manner that reveals the Abrahamic God as the texts are read. The language type and the literary form used to compose the sacred texts allow for the reading of the texts to be

\footnotetext{
1 Northrop Frye. The Great Code. (Toronto: Academic Press Canada, 1982) p. xxviii.

2 The term Torah is used throughout this investigation as a reference to the Tanakh, it includes the writings of the Torah "Five Books of Moses" or Pentatuch, Nevi'im "Prophets" and Ketuvim "Writings."
} 
generative. That is, the sacred texts are not strictly denotative; in order to discover the Abrahamic God and understand the divine message enclosed within the texts, they must be interpreted. The poetic and visual language of the sacred texts requires a hermeneutic reading that draws upon the creative imagination of the reader. Meaning taken from the sacred texts forms the underlying moral foundation of the faithful and shapes their perception of the physical world and the spiritual world beyond them.

\subsection{Northrop Frye: Language Framework}

As literature, the Abrahamic texts are difficult to categorize. They do not conform to a common language, mode of writing, or literary type. The disjunction between these texts and the function of most modern texts contributes to our misunderstanding.

As a means of navigating the numerous books of the Torah and the New Testament, Northrop Frye turns to Giambattista Vico. In the fourth book of The New Science of Giambattista Vico, "The Course of Nations," Vico addresses the problem of language as a cultural and as a historical phenomenon. ${ }^{3}$ Vico did so by dividing history into three ages. Each age is associated with a distinct language: Poetic, Heroic and Vulgar. ${ }^{4}$ Each period is defined by the type of writing it produced. Frye notes that the language of the Abrahamic texts does not lend itself to Vico's categorization. Frye discusses the unique language of the Torah and the Christian Bible in The Great Code. Using the Vico's theory of culture as a framework, Frye establishes a fourth language, type that he identifies as "Revelation." Although Frye examines only the Jewish and Christian sacred texts, we will include the Qur'an in our discussion of "Revelation" language.

${ }^{3}$ Giambattista Vico. The New Science of Giambattista Vico. (New York: Cornell University Press, 1948) p. 306.

${ }^{4}$ Northrop Frye. The Great Code. (Toronto: Academic Press Canada, 1982) p. 5. 


\subsubsection{Poetic language}

In order to understand "Revelation" language it is necessary to discuss the characteristics of the three languages Vico defines in his Theory of Culture. In the first period, the "Poetic," Frye suggests that words are used as hieroglyphics or signs; they are metaphorical and serve as imaginative representations of the physical things. ${ }^{5}$ Vico uses Homer to illustrate poetic language. Following Frye's characterization, the vocabulary of Homer appears metaphorical to the modern reader but reflects an understanding of the world that does not recognize an ontological separation of signifier and signified. ${ }^{6}$ While the Abrahamic texts differ, in part, from the writings of the "Poetic" period, poetic language is employed throughout the sacred texts as a means of making present, through words, the intangible Abrahamic God. One example can be found in the Book of Exodus.

After escaping Egypt and traversing the Red Sea, the Hebrew's find themselves in the desert at the base of Mount Sinai. Moses is called to the mountain where Yahweh informs him that he will be descending from heaven in a dense cloud to speak with the Hebrews.

\footnotetext{
On the morning of the third day there was thunder and lightning, with a thick cloud over the mountain, and a very loud trumpet blast. Everyone in the camp trembled. Then Moses led the people out of the camp to meet with Yahweh, and they stood at the foot of the mountain. Mount Sinai was covered with smoke, because the lord descended on it in fire. The smoke billowed up from it like smoke from a furnace, the whole mountain trembled violently, and the sound of the trumpet grew louder and louder. Then Moses spoke and the voice of Yahweh answered him. (Exodus 19:16-19)
}

This account of God descending to Mount Sinai is filled with poetic-visual language; it is used to give shape and character to the incomprehensible. Yahweh's presence is equated with a trumpet blast, fire, and dense smoke and cloud. Visual motifs used in the Torah are revisited in New

\footnotetext{
${ }^{5}$ Northrop Frye. The Great Code. (Toronto: Academic Press Canada, 1982) p. 6.

${ }^{6}$ lbid.
} 
Testament writings that fuse Christ with the prophetic imagery of the Hebrews. For example, John's apocalyptic dream reveals Jesus descending upon a cloud (Revelation 14:14-16). Having broken the seventh and final seal, heaven is silenced before the golden censer is emptied raining fire and lighting upon the earth. A trumpet blast from the first of seven angels, unleashes a hail storm of fire which falls into a sea filled with blood. A fallen star possesses the key that opens the abyss, extruding smoke like a gigantic furnace. The seventh trumpet is released; the Temple of God is opened and voices from heaven prepare the way for Jesus.

... before me was a white cloud, and seated on the cloud was one 'like a son of man' (Daniel 7:13) with a crown of gold on his head and a sharp sickle in his hand. Then another angel came out of the temple and called in a loud voice to him who was sitting on the cloud, 'take your sickle and reap, because the time to reap has come, for the harvest of the earth is ripe.' So he who was seated on the cloud swung his sickle over the earth, and the earth was harvested. (Revelation 14:14-16)

A similar vision of the end of days is described by the prophet Muhammad in Sura 44 titled, "Smoke (Ad-dukhan)."

Lord of the heavens and the earth and all that is between them, if you would really believe. There is no god but He. He grants life and deals death: He is your Sustainer as well as the Sustainer of your forebears of old. Nay, but they play in doubt. But watch you (Muhammad) for the day when the sky will produce visible smoke, that will envelop the people. This will be a painful punishment. (Sura 44:7-11)

Allah's image of the cloud of smoke surrounding the earth on the Day of Judgment along with those John describes in the book of "Revelation" mirror the language founded in the Torah. The imagery used in the Pentateuch and reiterated in the New Testament and the Qur'an, exemplifies the use of poetic-visual language in the Abrahamic tradition as a means of describing the elusive nature of their mythological universe. 


\subsubsection{Metonymic language}

According to Frye the writings of Plato mark a distinct end to "Poetic" language and generate a second language period identified by Vico as "Heroic." Frye describes the language of Plato as moving away from the metaphorical inter-relationships between words and things. What characterizes the second period of language is "metonymy" where words are not co-substantial but used in place of things or thoughts. In Timaeus, Plato uses "Becoming" to describe the existence of a transcendental order in addition to the natural physical world. ${ }^{8}$ "Metonymic" language draws a separation between subject and object, which allows for the possibility of abstraction. Words are used to represent thought, or similarly something that is not the word itself. Words attain further dimension in Metonymic language by focusing the use of metaphor through allegory: "... which is a special kind of analogy, a technique of paralleling metaphorical language with conceptual language where the latter has primary authority. Allegory smooths out the discrepancies in a metaphorical structure by making it conform to a conceptual standard." 9

For example, the Book of Jeremiah records a thunderstorm of armed chariots departing from the hills of Ephraim. Trumpets screamed as the battle surrounded the city of Jerusalem. After the Lord searched the streets of the city and found not one honest man, the sickle fell upon the daughter of Zion and not a stone of the city of Jerusalem remained in place. The Israelites were scattered, taken as slaves to the Babylonian king Nebuchadnezzar. Following Jeremiah's account of the destruction of Zion is the book of "Lamentations" containing a collection of funeral poetry written for the dead city of Jerusalem.

\footnotetext{
${ }^{7}$ Northrop Frye. The Great Code. (Toronto: Academic Press Canada, 1982) p. 7.

8 Plato. Timaeus and Critias. (New York: Penguin Books, 1977) p. 40.

${ }^{9}$ Northrop Frye. The Great Code. (Toronto: Academic Press Canada, 1982) p. 10.
} 
How deserted lies the city, once so full of people! How like a widow is she, who once was great among the nations! She who was queen among the provinces has now become a slave. Bitterly she weeps at night, tears are on her cheeks. Among all her lovers there is none to comfort her... After affliction and harsh labor, Judah has gone into exile. She dwells among the nations; she finds no resting place. All who pursue her have overtaken her in the midst of her distress. The roads to Zion mourn, for no one comes to her appointed festivals. All her gateways are desolate, her priests groan, her young women grieve, and she is in bitter anguish. Her foes have become her masters; her enemies are at ease. The LORD has brought her grief because of her many sins. Her children have gone into exile, captive before the foe. All the splendor has departed from Daughter Zion. Her princes are like deer that find no pasture; in weakness they have fled before the pursuer. In the days of her affliction and wandering Jerusalem remembers all the treasures that were hers in days of old... Is any suffering like my suffering that was inflicted on me, that the LORD brought on me in the day of his fierce anger? 'From on high he sent fire, sent it down into my bones. He spread a net for my feet and turned me back. He made me desolate, faint all the day long... 'The Lord has rejected all the warriors in my midst; he has summoned an army against me to crush my young men. In his winepress the Lord has trampled the Virgin Daughter Judah. 'This is why I weep and my eyes overflow with tears... Zion stretches out her hands, but there is no one to comfort her. The LORD has decreed for Jacob that his neighbors become his foes; Jerusalem has become an unclean thing among them. 'The LORD is righteous, yet I rebelled against his command. Listen, all you peoples; look on my suffering. My young men and young women have gone into exile. 'I called to my allies but they betrayed me. My priests and my elders perished in the city while they searched for food to keep themselves alive. 'See, LORD, how distressed I am! I am in torment within, and in my heart I am disturbed, for I have been most rebellious. Outside, the sword bereaves; inside, there is only death... All my enemies have heard of my distress; they rejoice at what you have done. May you bring the day you have announced so they may become like me. 'Let all their wickedness come before you; deal with them as you have dealt with me because of all my sins. My groans are many and my heart is faint. (Lamentations 1:1-22)

The funeral poetry of Lamentations is an example of metonymic language as allegory.

The city of Jerusalem is a metaphorical image of the temple, the Israelites hold God in their

thoughts and beliefs and thus, He dwells in and among them. The city of God, Jerusalem, is also

the nation of Israelites. The allegory places Jerusalem as a woman lamenting the loss of her self; she is both a thing (city of Jerusalem) and image (Temple of God in the "Poetic" sense), and an idea (Jewish theology) in the "Metonymical" sense. The allegory composed of Metonymical language contains a narrative that reveals an aspect of Jewish theology.

In the New Testament, Jesus is also represented with Metonymic language. Jewish terms and images are used metaphorically to describe the new Covenant that will follow the crucifixion of Jesus and lay the foundation for Christian theology. According to the Gospel of John, around the 
time of Passover, Jesus made his way to Jerusalem (John 12). When he arrived at the temple he was displeased with what he saw. The temple court was filled with merchandise; Jesus became upset and scolded the people for appropriating his Father's house with a market, and urged them to leave. Angered by the flamboyant accusations, the Jewish merchants questioned Jesus, asking: "... What miraculous sign can you show us to prove your authority to do this?" Jesus answered, "Destroy this temple and I will raise it again in three days." The Jews replied, "It has taken forty-six years to build this temple, and you are going to raise it in three days? But the temple he [Jesus] had spoken of was his body." (John 2:18-21). John 20 tells us that, three days after the crucifixion of Jesus he rose from the dead and appeared to the disciples, fulfilling the prophecy found in Daniel 9:25-26 and Isaiah 9:6||49:6 and reminding the disciples of the metaphor Jesus drew between the image of his body and that of the temple. According to Daniel 9:27, the Anointed One or the messiah, was to bring an end to sacrifice and offerings, the traditional functions performed in the temple. Paul in his first letter to the Corinthians builds upon Jesus' temple metaphor by explaining to the Christian believers: "God raised the Lord from the dead, and he will raise us also. Do you not know that your bodies are members of Christ himself? ...your body is a temple of the Holy Spirit..." (1 Corinthians 16). Paul further explains in 1:3: "Don't you know that you yourselves are God's temple and that God's Spirit lives in you? If anyone destroys God's temple, God will destroy him; for God's temple is sacred and you are that temple." The temple metaphor Jesus creates in the gospel of John along with the temple metaphor Paul draws in 1 Corinthians can be read as a metaphor comprised of metaphors. The 'body' was placed for the 'temple' and further, the body or congregation of believers is the body of Christ who is the temple.

In Sura 17, the prophet Muhammad is carried through the night on the wings of the Allah's angels and delivered to the city of Jerusalem where the revelation came to him. Prior to his return 
home, Muhammad is drawn from the Temple precinct and taken through the seven heavens where he was placed before the presences of the Lord. Sura 17, titled "The Night Journey," is an expression of reconciliation between Jewish imagery and theology and Islamic imagery and theology. Metonymical language is used in the Qur'an is similar to that found in the New Testament. Metaphorical imagery is placed within allegorical structures as a method of interconnecting the individual Abrahamic theologies.

Glory be to Him Who carried His servant by night from the Sacred Mosque to the remote mosque of which We have blessed the precincts, so that We may show to him some of Our signs; surely He is the Hearing, the Seeing. And We gave Moses the Book and made it a guide to the children of Israel, saying "Take no a protector besides Me." The seed of those whom We carried along with Noah. Assuredly He was a grateful servant. And We forewarned the children of Israel in the Scriptures: "You shall verily work corruption in the earth twice, and shall become great tyrants. When the time for the first of the two came, We roused against you the slaves of Ours of great might, who wrought destruction through the land; and it was a promise fulfilled. Then We gave you back the turn to prevail against them, and aided you with wealth and children and made you a numerous band. If you do good, you will do good for your own souls, and if you do evil, it shall be against yourselves. So when the second promise came (We raised another people) that they may bring you to grief and that they may enter the Temple as they entered it the first time, and that they might destroy whatever they gained ascendancy over with utter destruction. It may be that your Lord will have mercy on you, and if you again return (to disobedience) We too will return (to punishment), and We have made hell a prison for the disbelievers... Glory be to Him and exalted be He in high exaltation above what they say. The seven heavens declare His glory and the earth (too), and those who are in them; and there is not a single thing but glorifies Him with His praise, but you do not understand their glorification; surely He is Forbearing, Forgiving. (Sura 17:1-4)

It is not explicitly stated in "The Night Journey" that the "remote mosque" is in fact the Temple mount in Jerusalem. At the time the Sura was written, between 617-624 C.E., little more then dust remained of the Temple following Titus' besiegement of Jerusalem in $70 \mathrm{C}$.E. The absence of a temple or mosque in Jerusalem at the time suggests that the imagery rendered in "The Night Journey" is metaphorical. Similar to Jesus' metaphor in the book of "John," Muhammad's journey to the temple mount and ascension to heaven, anchor Islamic theology within the metaphorical imagery of the Abrahamic faiths. The "The Night Journey," also referred to as "The children of Israel" in some Qur'anic translations, begins and ends with references to revelation Moses received. Following the opening of Sura 17, describing Muhammad's flight to the 
Temple mount to receive revelation, it is stated that Moses was given the "Book" as a guide for the children of Israel. (Sura 17:2) The "Poetic" imagery associated with Moses receiving the "Book" or "Law" on Mount Sinai is mirrored in Muhammad's "Night Journey." As Moses was called by God to ascend Mount Sinai into the dark cloud of fire and smoke that hovered above the mountain to receive revelation in the book of Exodus (Exodus 19,20), Sura 17 tells us that Muhammad was also called by God to Mount Zion and drawn into heaven where he received guidance for Islam. The metaphorical imagery created in "The Night Journey" fuses the revelation of Moses with the revelation of Muhammad.

\subsubsection{Descriptive language}

The last language period Frye referrers to in Vico's cultural cycle are termed "Demotic" or "Vulgar." The roots of Vulgar language are formed in the Renaissance and the Reformation. ${ }^{10}$ Frye argues that demotic language begins with Francis Bacon and is extended through Locke. ${ }^{11}$ The Vulgar, or what Frye characterizes as "Descriptive," is defined by an ontological separation between subject and object. A natural order is observed objectively and described by the subject whose thought and words accurately reflect their observation. ${ }^{12}$ Descriptive language is the language that is most commonly used in contemporary western culture. As a result, it is also most commonly used in the academic reading of the Abrahamic texts. "Descriptive" language leads the reader to pay particular attention to details; the assumption is that the text is denotative and should be read literally. Because portions of the Abrahamic texts are read in Descriptive language, the texts are sometimes confusing because it is unclear as to where the Descriptive language ends and one of the various other modes of writing begins. Determining if narratives and events within

10 Northrop Frye. The Great Code. (Toronto: Academic Press Canada, 1982) p. 13.

11 lbid.

12 lbid. 
the text can be read literally as one would read a history, provides a distinct but complementary understanding. Accounts found within the sacred texts can be cross-referenced with the archeological record and other historical documents to verify if Abrahamic events did in fact take place.

\subsection{Revelation Language}

Following the language framework set forward by Frye, the Abrahamic texts generate their own logic and language type, because they are not entirely "Poetic", "Metonymic" or "Descriptive." Rather, they are a unique fusion of all of them. ${ }^{13}$ The sacred texts seamlessly flow from "Descriptive" history to "Poetic" allegories with no apparent boundary delineating language types. Frye contends that the Torah and the New Testament defy Vico's categorization and an additional language he terms "Kerygma" or "Revelation" is needed to properly place them within the writings of western culture. ${ }^{14}$ The unique language Frye draws from the Abrahamic sacred texts is what he calls a mode of rhetoric. Unlike other forms of rhetoric, the sacred texts do not contain an argument. "Revelation" language is overtly visual, from Noah's Ark floating above the endless sea (Genesis $6,7,8,9)$ and the four winged four headed creatures of Ezekiel (Ezekiel 1:13-17), to the four coloured horsemen of John's apocalypse (Revelation 6:1-8) and the heavenly gardens of Muhammad (Sura 79:41), the Abrahamic texts are saturated with poetic and metaphorical imagery. The numerous literary devices that compose "Revelation" language, such as, metaphor, analogy, parable and allegory, enable divine meaning to be drawn out of the images and events the texts render. Frye notes that: "The events the Bible describes are what some scholars call "language events, "brought to us only through words; and it is the words themselves that have the authority,

${ }^{13}$ Northrop Frye. The Great Code. (Toronto: Academic Press Canada, 1982) p. 29.

$14 \mathrm{lbid}, \mathrm{p} .29$. 
not the events that they describe." 15 Throughout the Abrahamic texts meaning is revealed through "language events".

Frye suggests that the verbal structure of the Torah and the New Testament resemble "Myth," which he defines primarily as Mythos, being words, narratives or "language events" 16 ordered in a specific sequence. Thus, Mythos is understood to have a similar meaning as argument within "Descriptive" language. ${ }^{17}$ Frye further discusses Myths as narratives to which a society draws its importance from, perhaps revealing its morals, gods, or history. Following the development of "Metonymical" language Myths are used as illustrations of abstract arguments or allegories. ${ }^{18}$ Frye discusses the Torah and the New Testament as Myths to avoid the tendency within "Descriptive" language to read the texts literally. Frye suggests the Abrahamic sacred texts are to be read poetically as one would a Myth to assure the texts credibility and remove the notion that the sacred texts are what we would understand as historical documents. Myths are made in a way that the truth of the Myth lies within its structure, the plot outlines an event, but the truth is not restricted to the event itself. Likewise, events in the Abrahamic texts and the imagery used to represent them are not meant to withhold meaning but to reveal the moral, spiritual, spatial reality of the Abrahamic universe through timeless imaginative interpretation.

\footnotetext{
${ }^{15}$ Northrop Frye. The Great Code. (Toronto: Academic Press Canada, 1982) p. 60.

16 lbid.

17 lbid, p. 31

$18 \mathrm{lbid}$, p. 33.
} 


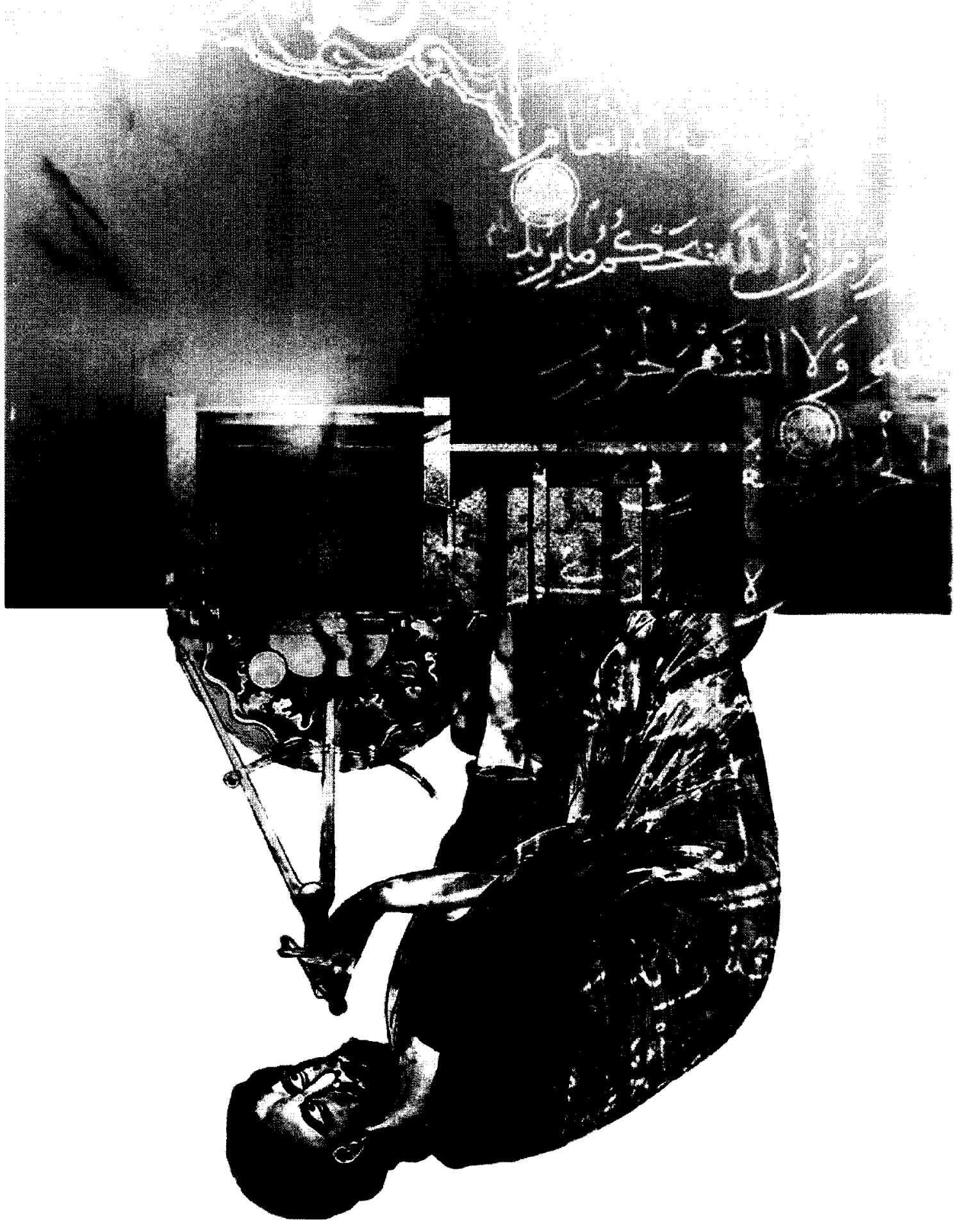




\subsection{Allegory:}

Allegory was introduced earlier as a type of narrative in which culturally significant meaning can be drawn from the events and images that compose the allegory. Frye discusses it as a device within Metonymical language used to reconcile dissimilar or contradictory things. ${ }^{19}$ Frye further explains it as ".... a technique of paralleling metaphorical with conceptual language in which the later has the primary authority." ${ }^{20}$ Allegory is a literary device capable of communicating things beyond the limitations of descriptive language and can be used to convey ideas that cannot be objectively described. Allegories are created with the intention that they will be interpreted. It is through the process of interpretation that the allegory reveals its meaning. For the historian, and other descriptive readers, the problem with allegory as a communicative device is that it bares such a close resemblance to narrative that it is often overlooked. On the inverse side, in writing, narrative is sometimes used to camouflage allegory so the message is revealed to only those who hold the hermeneutic key. Allegory is used throughout the Abrahamic texts to reveal and to hide the character God.

The language of the Abrahamic texts is intricate. It is often difficult to determine when the events and images of sacred texts are descriptive and when they are poetic or metaphorical. The ambiguity of the sacred texts occasional leads to the uncertainty of whether an event is descriptive, and assumingly historical, or poetic such as a parable. Because the Abrahamic sacred texts are believed to house the Word of God and reveal it via the literary device of Revelation language, all images and events can be read allegorical. It is not important to the believer to discern the descriptive from the poetic; through allegory all imagery and events reveal the Abrahamic God.

\footnotetext{
${ }^{19}$ Northrop Frye. The Great Code. (Toronto: Academic Press Canada, 1982) p. 10.

$20 \mathrm{lbid}$.
} 
The innumerable allegories that collectively give form to the greater or universal allegory found in the Abrahamic scripture are placed at varying depths within the texts. The specific allegorical type and its application also vary throughout the Abrahamic texts. Although several types of allegories are employed throughout the Torah, New Testament, and Qur'an, we will discuss a specific type of allegory in association with each of the Abrahamic texts. The allegorical variation found within the three texts provides a distinction with respect to the individual faiths, while revealing the common framework they collectively share.

\subsection{Torah (Numbers 20: 5-12)}

The images and characters described in allegories may reflect historical events but more importantly they are "language events." 21 Allegorical events found within the Torah are of this type. The events are believed to have taken place in some likeness to that represented in the Torah, but the purpose of the text is not to record the event in a "Descriptive" manner, rather, the Torah is written primarily as allegory.

The earliest scrolls written in the Abrahamic tradition are those contained within the Torah. The first five books, referred to as the Pentateuch: Genesis, Exodus, Leviticus, Numbers, and Deuteronomy, are believed to be written by Moses under divine inspiration. This notion of a single author was first questioned by Jean Astruc in the eighteenth century. Astruc drew attention to the fact that throughout the Torah, God was referred to as both Yahweh and Elohim, suggesting that the five books were the result of two traditions. ${ }^{22}$ Inspired by Astruc's questions, early modern

${ }^{21}$ Northrop Frye. The Great Code. (Toronto: Academic Press Canada, 1982) p. 60.

22 Willard Oxtoby. World Religions. (Don Mills: Oxford University Press, 2002) p. 48. 
scholars developed more sophisticated theories which concluded that the five books of Moses were composed from four different sources. The Yahwist (J), wrote their documents from the southern kingdom of Judea. ${ }^{23}$ While the Elohist $(E)$, were writing in the ninth century BCE from the northern kingdom. Deuteronomy is thought to be a separate source (D), which was discovered during renovations to the temple in Jerusalem. The remaining source, called the Priestly $(P)$, is speculated to have been formed between 586-539 BCE during the Israelites exile from Jerusalem following the destruction of Solomon's temple. The P source offers a description of the Temple, complete with dimensions. It is thought that the four sources were stitched together by the priestly aristocracy during the Second Commonwealth between 538-331 B.C.E. ${ }^{24}$

The gap between the historical events of the Pentateuch and the time in which they were recorded, raises questions about the text as a historical document. That is not to deny the possible authenticity of the events, rather, it demonstrates that the purpose of the Pentateuch is to portray the essence of the events and to capture their theological significance. Because emphasis is placed on the theological interpretation of these ancient events, the Pentateuch can be read as a collection of allegories. For instance, Numbers 20: 5-12 narrates Moses and the Hebrews journey through the desert after crossing the Red Sea. The duration of their travels has left the Hebrews with little faith that God really intends to lead them to the Promised Land. They begin to question Moses and their God:

And wherefore have ye made us to come up out of Egypt, to bring us in onto this evil place? It is no place of seed, or of figs, or of vines, or of pomegranates; neither is there any water to drink.' And Moses and Aaron went from the presents of the assembly onto the door of the tent of meeting, and fell upon their faces; and the glory of the LORD appeared onto them. And the lord spoke onto Moses, saying: 'Take the rod and assemble the congregation, thou, and Aaron thy brother, and speak ye unto the rock before their eyes, that it give forth its water; and thou shalt bring forth to them water out of the rock; so thou shalt give the congregation and their cattle drink.' And Moses

23 Willard Oxtoby. World Religions. (Don Mills: Oxford University Press, 2002) p. 48.

24 Ibid, p. 57. 
took the rod from the LORD, as he commanded him. And Moses and Aaron gathered the assembly together before the rock, and he said unto them: "Hear now, ye rebels; are we to bring you forth water out of this rock?' And Moses lifted up his hand, and smote the rock with his rod twice; and water came forth abundantly, and the congregation drank, and their cattle. And the LORD said unto Moses and Aaron: 'Because ye believed not in Me, to sanctify Me in the eyes of the children of Israel, therefore ye shall not bring this assembly into the land which I have given them. (Numbers 20:5-12)

The story of Moses smiting the rock, invites several possible readings. A traditional or literal reading presents the reader with evidence of Gods intervention in the material world where natural laws are altered at will. If the poetic visual language of the text is interpreted or translated into imagery similar to that found within the Dura-Europos synagogue (Fig. 1), the word "rock" signifies a well that has gone dry. In this second reading the emphasis of the narrative is not placed on the miracle, or impossibility of water flowing from a rock, but instead on Gods provision of water to fill a dry well. The narrative excludes the details pertaining to how the well was filled. The specifics are not as important as the latent massage that God provides for those who are faithful. If the image is examined even closer it is possible that the "water" referred to in the narrative is metaphorical, similar to Jesus' reference to the water as Holy Spirit in his discussion along side a well with the Samaritan woman (John 4:7-14). An allegorical interpretation of the narrative suggests the possibility of multiple meanings. For example, the allegory could be teaching believers to maintain faith in God, suggesting the Israelites should not doubt the covenant He established with Moses. The allegory may also contain a warning for those who doubt God, suggesting that they will be forgotten in the desert of the earth and never reach the Promised Land.

\subsection{New Testament (Mark 4:3-20)}

Parable is similar to allegory, in that it too conveys a truth revealed through narration, indirectly. Throughout the Torah, New Testament and the Qur'an, parable is assumed to be fictitious and requiring interpretation. A substantial portion of the revelation of Jesus is represented 


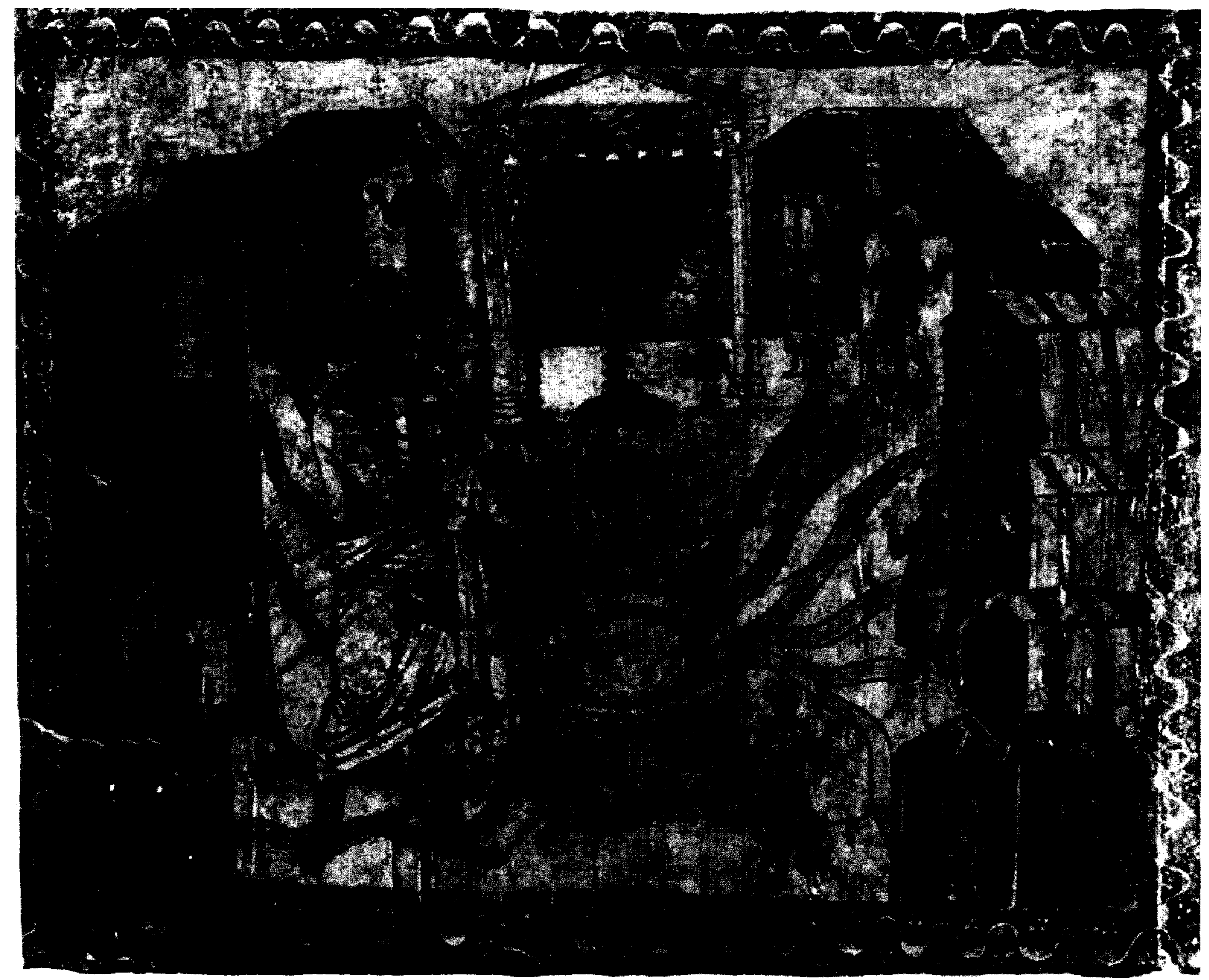

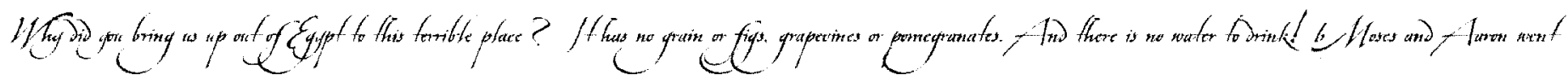

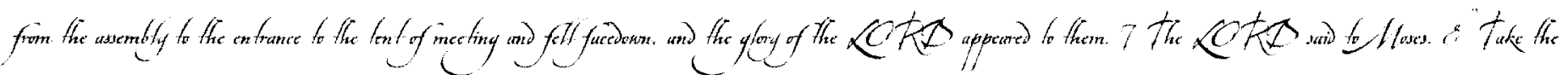

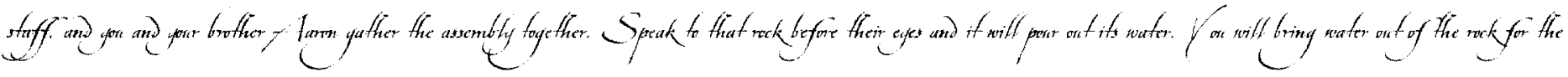

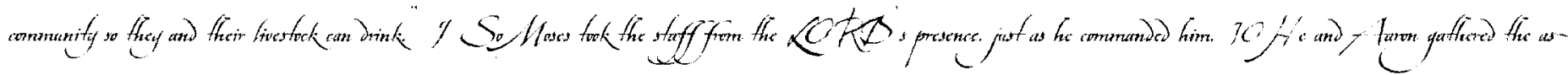

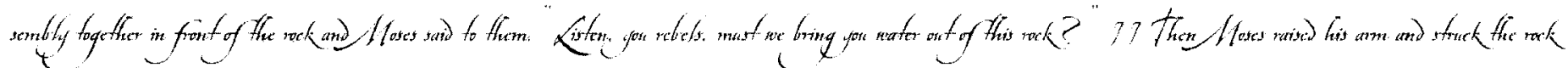

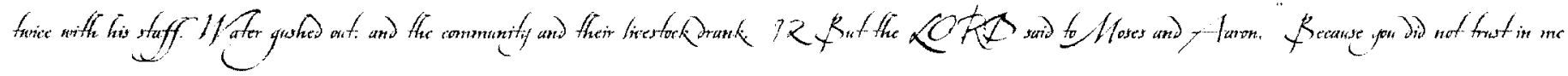

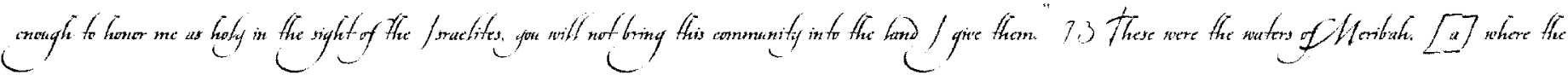

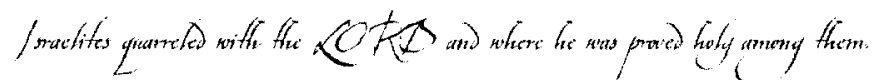


through parables. Jesus, in the New Testament, explicitly discusses parables and their interpretation.

The gospel of Mark describes Jesus and his disciples teaching alongside the waters edge. The crowd of people who came to hear him speak grew to such a great number; Jesus got into a boat and continued to teach parables from the water:

\begin{abstract}
A farmer went out to sow his seed. As he was scattering the seed, some fell along the path, and the birds came and ate it up. Some fell on the rocky places, where it did not have much soil. It sprang up quickly, because the soil was shallow. But when the sun came up, the plants were scorched, and they withered because they had no root. Other seed fell among the thorns, which grew up and choked the plants, so that they did not bear grain. Still other seed fell on good soil. It came up, grew and produced a crop, multiplying thirty, sixty, or even a hundred times.' Then Jesus said, 'He who has ears to hear, let him hear.' When he was alone, the Twelve [disciples] and the others around him asked about the parables. He told them, 'The secret of the kingdom of God has been given to you. But to those on the outside everything is said in parables so that, "they may be ever seeing but never perceiving, and ever hearing but never understanding; otherwise they might turn and be forgiven." (Isaiah 6:9-10) Then Jesus said to them, 'Don't you understand this parable? How then will you understand any parable? The farmer sows the word. Some people are like seed along the path, where the word is sown. As soon as they hear it, Satan comes and takes away the word the word that was sown in them. Others, like seed sown on rocky places, hear the word and at once receive it with joy. But since they have no root, they last only a short time. When trouble or persecution comes because of the word, they quickly fall away. Still others, like seed sown among thorns, hear the word; but the worries of this life, the deceiffulness of wealth and the desires for other things come in and choke the word, making it unfruitful. Others, like seed sown on good soil, hear the word, accept it, and produce a crop thirty, sixty or even a hundred times what was sown. (Mark 4:3-20)
\end{abstract}

Following Jesus' explanation of the parable he continued with another parable. Jesus asked his disciples if they cover their lamps with bowls so that the light remains hidden or do they place the lamp on a stand where the light reveals all that is concealed. In an attempting to explain his will to reveal Gods Word to the people, Jesus then refers back to the first parable and adds that the kingdom of God is like a man who scatters seed. Night and day pass and the seed develops into a kernel of grain, when the grain is ripe God harvests his crop with a sickle (Mark 4:21-29). Jesus creates parables out of other parables, interweaving them in a way that if one parable was removed the others would be incomplete. Jesus' interwoven composition of parables is set within 
an allegorical structure or the book of Mark, which binds the numerous parables together, as it is bound to the other Abrahamic texts.

\title{
2.3 Qur'an (Surah 24:35, Surah 2:26)
}

Muhammad is addressed in the Qur'an regarding the misinterpretation of parables, Allah insists there use is necessary to reveal the divine message. The Lord is quick to condemn those who purposefully misinterpret Allah's connotative language to misconstrue his revelation. The Qur'anic use of allegory is similar to that found in the New Testament where the reader is aware that the event is a parable. However, the contents of the events largely consist of poetic imagery, returning, in a way, to the poetic events of the Torah, without the historical camouflage. The narratives of Qur'anic parables are less elaborate than those found in the New Testament, greater emphasis is placed on creating metaphorical imagery with poetic visual language. For instance

Sura 24:35 describes Allah as metaphorical light:

\begin{abstract}
Allah is the Light of the heavens and the earth. The parable of His Light is as (if there were) a niche and within it a lamp: the lamp is in a glass, the glass as it were a brilliant star, lit from a blessed tree, an olive, neither of the east (i.e. neither it gets sun-rays only in the morning) nor of the west (i.e. nor it gets sun-rays only in the afternoon, but it is exposed to the sun all day long), whose oil would almost glow forth (of itself), though no fire touched it. Light upon Light! Allah guides to His Light whom He wills. And Allah sets forth parables for mankind, and Allah is AllKnower of everything. (Sura 24:35)
\end{abstract}

The parable of "The Light" revealed to Muhammad begins as a lucid metaphor and unfolds into a description/construction allegory of the Islamic world. A universe complete with physical and metaphorical divine light that glows from both the cosmic star enclosed within a glass jar and from the shining oil of the olive tree that requires no fire. The light of the world shines in two directions from the kingdom of heaven and the Lords creation, 'Light upon light!' 
The depth of the Abrahamic universe is rendered through allegories, The Prophet explains this in Sura 2:26, while clarifying Allah's intentions and defending the revelation of God against misinterpretation:

\footnotetext{
Verily, Allah is not ashamed to set forth a parable even of a mosquito or so much more when it is bigger (or less when it is smaller) than it. And as for those that believe, they know that it is the truth from their lord, but as for those that disbelieve, they say: 'What did Allah intend by this parable?' By it He misleads many, and many he guides thereby. And He misleads thereby only those who are Al-Fasiqun (the rebellious, disobedient to Allah). (Sura 2:26)
}

The sacred texts of Judaism, Christianity and Islam use allegory as a method of conveying the timeless truth of the Abrahamic God. The theology that gives shape to the Abrahamic religions and guides believers is latent within the imagery and events that shape the Abrahamic texts. Through a hermeneutic reading the Scriptures, they make visible the ephemeral reality of the Abrahamic God. The visual reality drawn from the allegory of Abrahamic texts, is manifest in other visual mediums. The archaeological record finds suggests that the predominate media used to unfold the language of Revelation is image. 


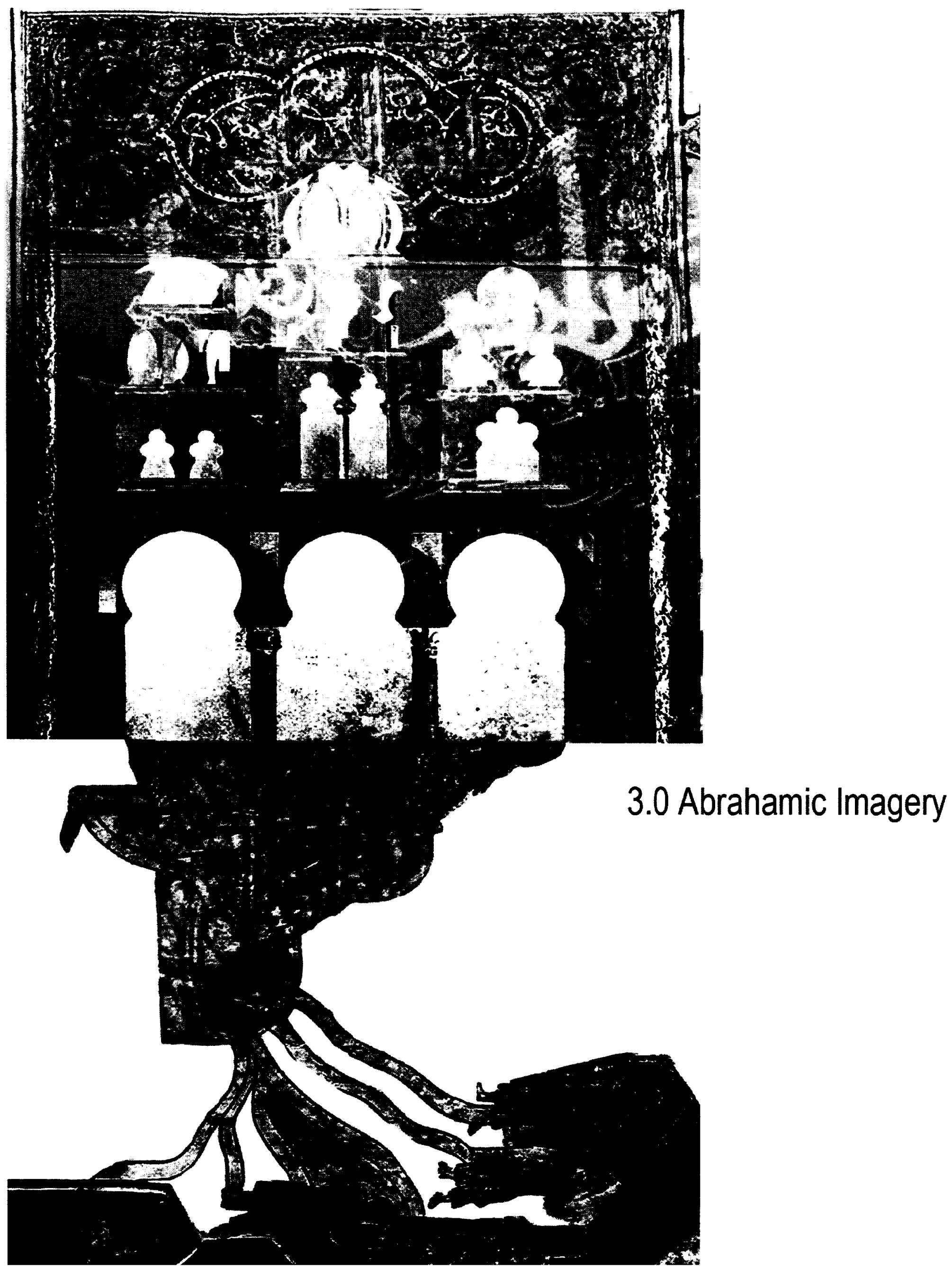




\subsection{Abrahamic Imagery:}

During the early developments of the Abrahamic faiths, poetic imagery created through "Revelation" language was predominantly rendered as text. In time, the poetic language was translated from text to image. The translation of the sacred texts into imagery added a new dimension to the Abrahamic tradition of allegory in that multiple narratives could now be represented simultaneously in a spatial medium that demonstrated a continuity between disparate allegories. The grouping of narrative images made textual relationships explicit to those familiar with the text as well as to those unable to read.

\subsection{Jewish Imagery}

Among scholars, the use of images in Judaism is a contentious subject. ${ }^{25}$ The relatively few known sources and artifacts that make up the historians palette of references has generated much speculation. As admittedly inconclusive as the theories may be, they form a foundation of knowledge that, while awaiting more conclusive evidence, suggests that Judaism has a history of using narrative images

It is presumed, generally, that images have no place in Judaism. One need look no further then Exodus 20 to discover that in the covenant made with the Hebrews, God explicitly states in the First and Second Commandments: "I am the LORD thy God, who brought thee out of the land of Egypt, out of the house of bondage. Thou shalt have no other gods before me. Thou shalt not make unto thee a graven image, nor any manner of likeness, of any thing that is in heaven above, or that is in the earth beneath, or that is in the water under the earth; thou shalt not bow down unto them, nor serve them..." (Exodus 20: 2-5).

25 Joseph Gutmann. No Graven Images. (New York: KTAV Publishing House Inc., 1971) p. 3. 
In Exodus 32, Aaron and the Hebrews began constructing a Golden Calf to worship. Upon Moses' return from Mount Sinai, he becomes enraged at the sight and destroys the stone tablets God inscribed the covenant upon. The first two Commandments that God outlines for the Hebrews equates images with gods and the people are instructed to rid themselves of both.

Hebrew theology can be understood as an opposition to the immanent world of the Egyptians; the invisibility of God underlies the separation between the realm of human endeavor and the realm of the divine. It is understood that God dwells in heaven, an immaterial space beyond the perception of humanity. In the few occasions when God bridges this spatial divide, and enters the material realm, the Torah describes his presence as an intangible visual phenomenon. When God descends upon the mountain to meet with Moses in "Exodus" chapter 19:16, he is described as a dense cloud with fire and smoke. Similarly in "Exodus" chapter 25:8, God asks the Hebrews to make for him a sanctuary so he can dwell among them in the desert. After obeying this request and constructing the tabernacle to the prescribed pattern, God enters the enclosure through a pillar of cloud (Exodus 33:9). Once the Hebrews arrived in the Promised Land (Jerusalem), the purple scarlet curtain and the tabernacle which clothed God in the desert, were exchanged for a stone veil and the Temple of Solomon. Like the Tabernacle, God revealed the Temple plan, unfolding it before the Hebrews with words and they built it as he instructed ( 1 Kings 6, 7). Scholars such as Joseph Guttmann have observed that liberties regarding the Second Commandment were certainly taken in the decoration of the first temple. ${ }^{26}$

${ }^{26}$ Joseph Gutmann. No Graven Images. (New York: KTAV Publishing House Inc., 1971) p. 7. 
Scholarship examining the use of imagery in Judaism has shifted significantly over the last century. Before the wall paintings at the Dura-Europos synagogue were unearthed in 1932, it was difficult for any scholar to make a convincing argument that images were used prior to the fifth century Synagogue mosaics in Palestine and the tenth century illustrated manuscripts of Cairo. ${ }^{27}$ Although examples of illustrated manuscripts that predate the 245 C.E. Dura-Europos paintings have not been found, based on the sophistication of theses images, it is now accepted that a tradition of illustration existed within early Judaism. ${ }^{28}$ Significantly, in 245 C.E, some $500-700$ years after the Torah scrolls were transcribed, there is evidence of the transformation of the poetic visual language of Judaic theology into imagery. This imagery is not an image of a material god, but a visual translation of sacred text. Further, the imagery is integrated into the synagogue architecture and reveals its message through the unfolding of space.

Located in the middle register on the west wall of the Dura-Europos synagogue, opposite the woman's entrance, was an image of Moses and the twelve tribes of Israel receiving water from a rock (Fig. 1). Although there are numerous images that adorn the walls of the Synagogue, all of which could be discussed as translations of sacred text, we will focus on this image of Moses to discover the transformation of meaning from the allegories of "Revelation" language to the realization of a distinct Jewish imagery.

The image depicts Moses facing forward and standing beside what appears to be a well. The scale of his body is enormous relative to the twelve other figures, standing at the threshold of

\footnotetext{
${ }^{27}$ Joseph Gutmann. No Graven Images. (New York: KTAV Publishing House Inc., 1971) p. 39.

28 Joseph Gutmann. The Dura-Europus Synagogue: a re-evaluation (1932-1992). (Atlanta: Scholars Press, 1992) p. $\mathrm{xxV}$.
} 
their tents, with hands raised towards heaven. The twelve tents represent the twelve tribes of Israel and are divided by a larger stone structure. The permanent building at the centre of the tribes is made with ornate stone columns. A large menorah is placed in front of the building, signifying that it is the tabernacle. The ambiguity of the image lies in the representation of Moses striking the rock or well with his staff and the mysterious streams of water that flow toward the twelve tribes. It appears that the image is a translation of Numbers $20: 5-12$. The image contains all of the visual objects described in the text and the location of the characters in the image alluded to the narrative of the story. However, not all scholars agree on the interpretation of the image. Goodenough believes the image depicts the Hebrews settling in Elim alongside the twelve streams, after Moses led them through the Red Sea (Exodus 15:22-27). ${ }^{29}$ Hopkins defends the Numbers20:5-12 interpretation, and further points out that the fish in the well symbolize that the water is not new, and the well should not be confused with the twelve wells at Be'er (Numbers $21: 16-18) .{ }^{30}$ Wischnitzer's theory states that the twelve streams that flow toward the tribes are symbolic of Moses giving the law. The image is thought by Wischnitzer to metaphorically represent the revelation of the covenant and the desert tabernacle written in chapters 19-26 of "Exodus." ${ }^{1}$

The various interpretations of the image bring to light an important thing to note about Abrahamic imagery, that is, it is connotative. Many believers among the three Abrahamic faiths see this fact as potentially dangerous, similar to allegory and parable it is possible to misinterpret images. However, like "Revelation" language and allegories the connotative quality of imagery is what is consistent with the hermeneutic tradition of the Abrahamic faiths. Abrahamic imagery

\footnotetext{
${ }^{29}$ Rachel Wischnitzer. The Messianic Theme in the Paintings of the Dura Synagogue. (Chicago: University of Chicago Press, 1948) p. 55.

${ }^{30}$ Clark Hopkins. The Discovery of Dura-Europos. (New Haven: Yale University Press, 1979) p. 159.

${ }^{31}$ Rachel Wischnitzer. The Messianic Theme in the Paintings of the Dura Synagogue. (Chicago: University of Chicago Press, 1948) p. 58.
} 
opens "Revelation" language to further understanding through interpretation via a spatial and figurative medium.

\subsection{Christian imagery}

In Colossians 1:15, we read that: "He [Jesus] is the image of the invisible God." Christian theology places Jesus as the incarnate son and a physical manifestation of the Abrahamic God. For Christians, Jesus, believed to be both human and divine, reconciled the spatial divide that polarizes the Abrahamic universe. With the physical form of Jesus, it became possible to represent God and the heavenly realm in the material world.

Prior to the commissioning of the Callistus catacomb paintings in Rome (c.190/200 C.E.) (Fig. 2), apologetic literature, namely Clement of Alexandria, suggests that Christians should adopt symbols to mark themselves as distinct among their Greco-Roman neighbors. ${ }^{32}$ Thus, Paul Corby Finney points out that Christian imagery first took the form of ready made Greco-Roman objects with graphic designs that served as abstract references to Christian theology. The earliest Christian iconography was adaptive, and existed more as an inclusive code then an exterior sign. Clement prescribes a dove, a fish, and a ships anchor as appropriate images that relate to the metaphorical imagery of the New Testament. The dove, referenced in all four gospels (Matthew 3:16, Mark 1:10, Luke 3:22, John1:32), symbolizes the moment of Jesus' baptism when heaven opened and the Holy Spirit descended. The fish, aside from the cross, is perhaps the most identifiable abstract Christian image. The Greek word for fish ixthus, is an acronym for Jesus Christ. As well, the fish refers to the gospels of Matthew and Mark that tell the story of the apostles Peter and Andrew. Jesus walked along side the Sea of Galilee while the men were casting their

32 Paul Finney. The Invisible God. (New York: Oxford University Press, 1994) p. 111. 


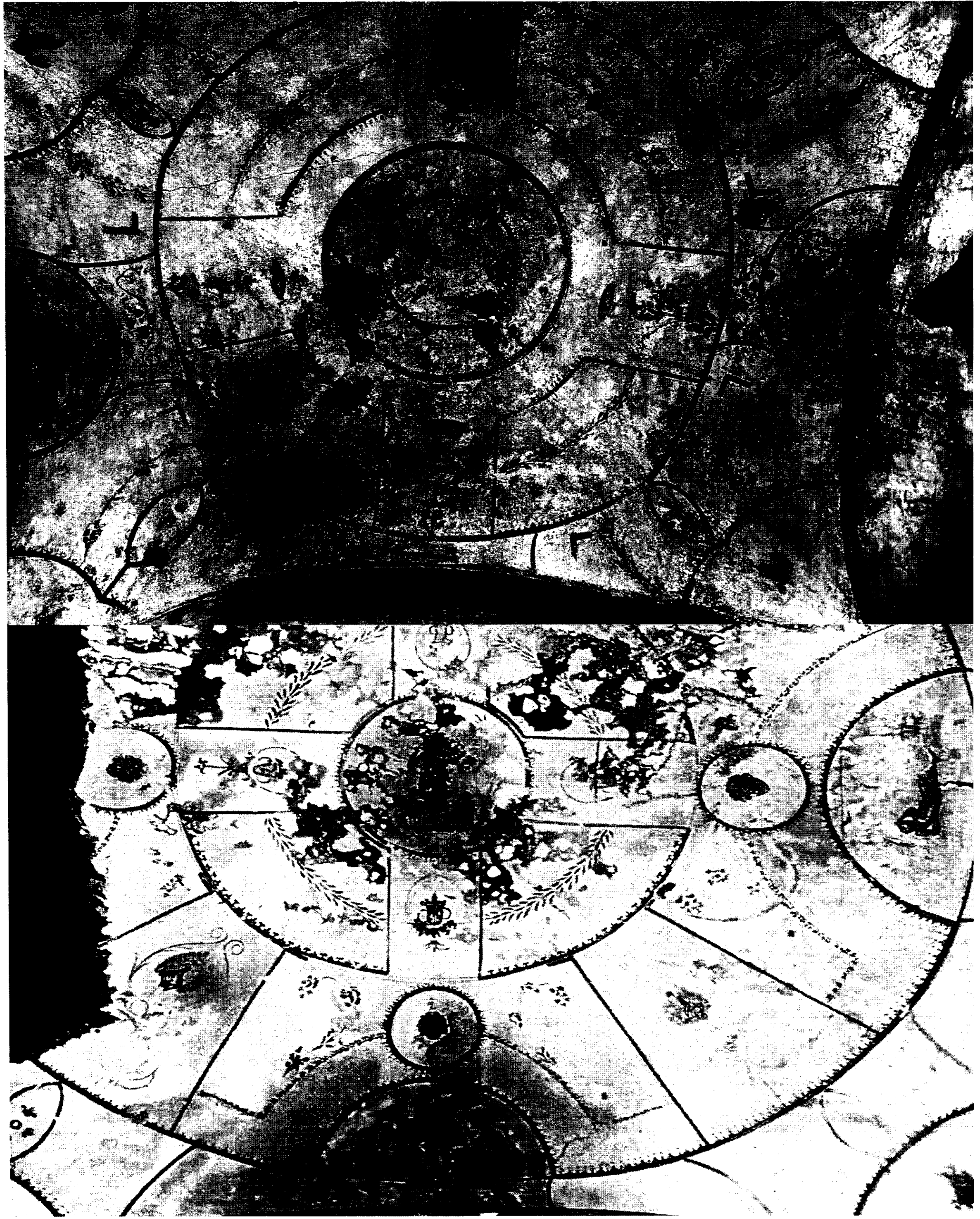

Fig. 2 
nets into the water, Jesus spoke to them and said "Follow me... and I will make you fishers of men." (Matthew 4:19). Metal rings and stones engraved with the images that Clement suggested were inexpensive and readily available in the established markets. ${ }^{33}$ The Christian iconic tradition begins as subversive form of Greaco-Roman material culture.

Finney, attempting to dispel arguments that early Christianity was iconoclastic states that: "The reason for the nonappearance of Christian art before 200 [C.E.] has nothing to do with a principled aversion to art, with otherworldliness or with anti-materialism. The truth is simple and mundane: Christians lacked land and capital. Art required both. As soon as they acquired land and capital, Christians began to experiment with their own distinctive forms of art." ${ }^{4}$ Finney's study provides evidence that visual representation began very early in the development of the Christian religion. Finney suggests the acquisition of land by Christian groups, around the year 200 C.E., provided the context for the emergence of a distinct Christian picture language. ${ }^{35}$

According to Finney, the origins of early Christian figurative art is marked by the Berlin lamp and the catacomb paintings at Callistus (C. 190/200-210/220 C.E.). ${ }^{36}$ Wall paintings found in the Dura-Europos House Church (240-250 C.E.) suggest that the Christian adoption of visual forms of communication was not isolated to Rome. However, because the Christian faith was so influenced by rabbinic Judaism, a lingering question remains to what degree Jewish illustration influenced the new Christian iconography. Joseph Guttmann and Kurt Weitzmann have both

\footnotetext{
${ }_{33}$ Paul Finney. The Invisible God. (New York: Oxford University Press, 1994) p. 111.

34 Ibid, p. 108.

35 Ibid, p. 110

36 lbid, p. 146.
} 
written about the Jewish origins of Christian art. Both Guttmann ${ }^{37}$ and Weitzmann ${ }^{38}$ reference the Ashburnham Pentateuch, an enigmatic illustrated manuscript whose origins have remained elusive. Their arguments are made not to discuss Christian illustration as much as to solidify imagery within Judaism. They conclude that early Christian illustrated manuscripts were based on Jewish manuscripts that have not yet been discovered.

Questions surrounding the mysterious Ashburnham Pentateuch are addressed in Dorothy Verkerk's Early Medieval Bible Illumination and the Ashburnham Pentateuch. Verkerk argues that the manuscript is of Italian origin, created in Rome in the late sixth or early seventh century, which places the illustrated manuscript between papacy of Pelagius (579-590) and Honorius I (625638). ${ }^{39}$ With regards to Jewish influences on the Ashburnham Pentateuch, Verkerk criticizes Gutmann and Weitzmann for their isolated study of individual images and for their arguments that the manuscript is an amalgamation of Jewish iconography. Verkerk concludes that the manuscript was made as a pedagogical reference for Christian clergy. Although she is careful not to deny the influence of Jewish images, Verkerk maintains that the images are not random collages. Her theory is based on the unique content and arrangement of images which refer to both the historical narrative of the five books of Moses as well as Christian practice and the tendency of early Christians to re-interpret Old Testament narratives into New Testament prophecy.

The Exodus account of God descending to Mount Sinai to meet Moses is represented visually in the Ashburnham Pentateuch (Fig. 3). The image is divided horizontally by two

\footnotetext{
37.Joseph Gutmann. No Graven Images. (New York: KTAV Publishing House Inc., 1971) p. 343.

38 Ibid, p. 327.

${ }^{39}$ Dorothy Verkerk. Early Medieval Bible Illumination and the Ashburnham Pentateuch. (Cambridge: Cambridge University Press, 2004) p. 129.
} 


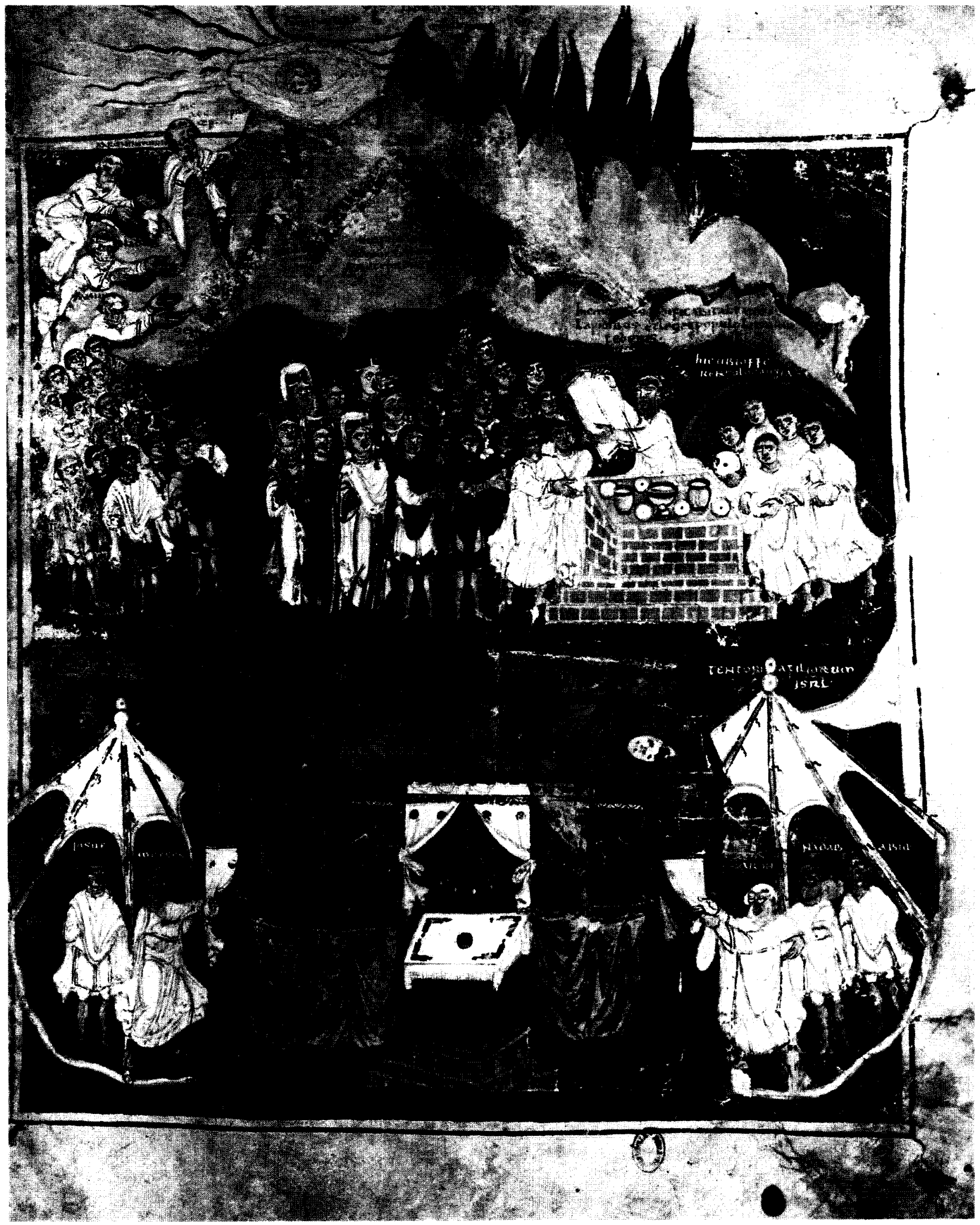

Fig. 3 
background colours, a burnt orange-red surrounds what appears to be the desert tabernacle in the bottom portion of the image, while a mountain and cloud of fire is set to a background of bluegreen. Extending beyond the thin red line that frames the image is a cloud, hovering above a mountain of fire. Moses accompanied by Aaron, stands adjacent to the cloud and opens his hands toward a figure within the cloud to receive the Law. The image is rendered reflect Exodus 19-20, save for the mysterious figure residing within the cloud. The cloud of fire is a metaphorical image of the invisible God. Colossians 1:15 denotes Jesus to be the image of the invisible God. It is assumed, therefore, that in this Christian image Jesus is the cloud of fire that Moses addresses on Mount Sinai. Below the mountain, Moses is depicted behind a stone altar presenting the two stone tablets to a crowd of people. Resting on the surface of the stone altar in front of Moses is what Verkerk has interpreted to be bread and clay vessels filled with wine. ${ }^{40}$ Exodus 24:4-8 describes Moses constructing a stone altar at the base of Mount Sinai where he offers the Lord burnt offerings and sacrificed bulls. The blood of the bulls is sprinkled on the surface of the altar and the Israelites agree to obey the Lord and establish a covenant with him. On the eve of Jesus' arrest, Luke 22 describes Jesus breaking bread with his twelve disciples. Jesus explains to his disciples that the bread is a metaphorical representation of his body given to them and that the bread is to eaten in remembrance of him (Luke 22:19). Jesus then offers the disciples wine and tells them: "This cup is the new covenant in my blood, which is poured out for you" (Luke 22:20). The Ashburnham Pentateuch draws a relationship between the sacrificed bread (body of Christ) and wine (Blood of Christ) of the new Christian covenant and the sacrificed bull and blood on the altar of the Jewish covenant. The tabernacle and its sacred articles occupying the centre of the lower portion of the image are flanked by two tents housing Joshua and Moses on the left side and

\footnotetext{
${ }^{40}$ Dorothy Verkerk. Early Medieval Bible Illumination and the Ashburnham Pentateuch. (Cambridge: Cambridge University Press, 2004) p. 90.
} 
Aaron, Nadab, and Abiu on the right side. ${ }^{41}$ Moses and Aaron draw back the curtain surrounding the tabernacle to reveal the inner sanctuary. A rough cut stone altar, similar to that represented in the upper portion of the images, is placed in front of the tabernacle with a wood altar substituted for a sacrifice. Verkerk suggests the wood altar is the Ark of the Covenant described in "Exodus" which represents, along with the opening of the inner sanctuary curtains, the new covenant accessible to all through the Christian church. ${ }^{42} \mathrm{~A}$ white candle, commonly used in Christian ritual as a symbolic representation of the birth of Christ, is drawn bridging the divided upper and lower portions of the image and connecting the tabernacle with the cloud of fire, similar to the pillar of cloud that visually describes the Lord's decent from heaven to earth in Exodus 33:9. The Ashburnham Pentateuch appears to reconcile the new Christian covenant with the covenant God established with Moses by representing Christian interpretations of Torah allegories. The image is composed of both Torah and New Testament imagery juxtaposed to reveal the symmetrical relationship between Jewish and Christian theology.

Verkerk's interpretation of the Ashburnham Pentateuch reveals the potential of imagery to reconcile diverse theology within the Abrahamic traditions. Similar to the Jewish allegorical images at Dura-Europos which rely, in part, on their spatial arrangement in the synagogue to convey their message , the Christian images found in the Ashburnham Pentateuch depict inter-related allegorical events selected from various portions of the sacred texts in the same image. The composition found within the Ashburnham Pentateuch displays time and movement within the narrative and reconciles the early revelation of the Hebrews with the new Christian covenant. The Dura-Europos synagogue paintings effectively achieve a similar result but through physical space

41 Dorothy Verkerk. Early Medieval Bible Illumination and the Ashbumham Pentateuch. (Cambridge: Cambridge University Press, 2004) p. 98.

42 lbid, p. 99. 
and movement. The images are placed on the walls in three dimensional spaces such that relationships can be drawn between the images, revealing a dimension within the sacred texts that is difficult to read in a linear reading of the text.

\subsection{Islamic imagery}

The tradition of Islamic imagery is unique among the Abrahamic faiths. Unlike Jewish and Christian imagery which is predominantly figurative, the visual language of Islam is embodied within the characters of Kufic calligraphy and Islamic patterns. According to Seyyed Hossein Nasr in Islamic Art and Spirituality, the character form of Kufic calligraphy, the Qur'anic text style, is allegorical. Nasr suggests that Qur'anic calligraphy is the visual expression of the Sacred Word ${ }^{43}$ : "The letters, words, and verses of the Qur'an are not just elements of a written language but beings or personalities for which the calligraphic form is the physical and visual vessel." 44 Kufic calligraphy is an image language. The pen that gives form to Islamic revelation represents the act of divine creation; Muslims, through perfect submission, become like the pen in the hand of God. ${ }^{45}$

Kufic calligraphy is thought to be the style closest to that which the Qur'an was first written ${ }^{46}$ under the auspices of the third caliph, between 644 and 656 C.E. 47 Illuminated between 1073 and 1074 C.E., the image of "The Opening" (Fig. 4) displays Kufic calligraphy as an intricate composition of flowing horizontal lines set within a rhythm of straight vertical lines, which are directed toward and metaphorically represent the divine. The interwoven calligraphic forms are

\footnotetext{
${ }^{43}$ Seyyed Hossein Nasr. Islamic Art and Spinituality. (Albany: State University of New York Press, 1987) p. 17.

44 lbid, p.18.

$45 \mathrm{lbid}, \mathrm{p} .21$.

46 lbid, p.31.

47 Willard Oxtoby. World Religions. (Don Mills: Oxford University Press, 2002) p. 357.
} 


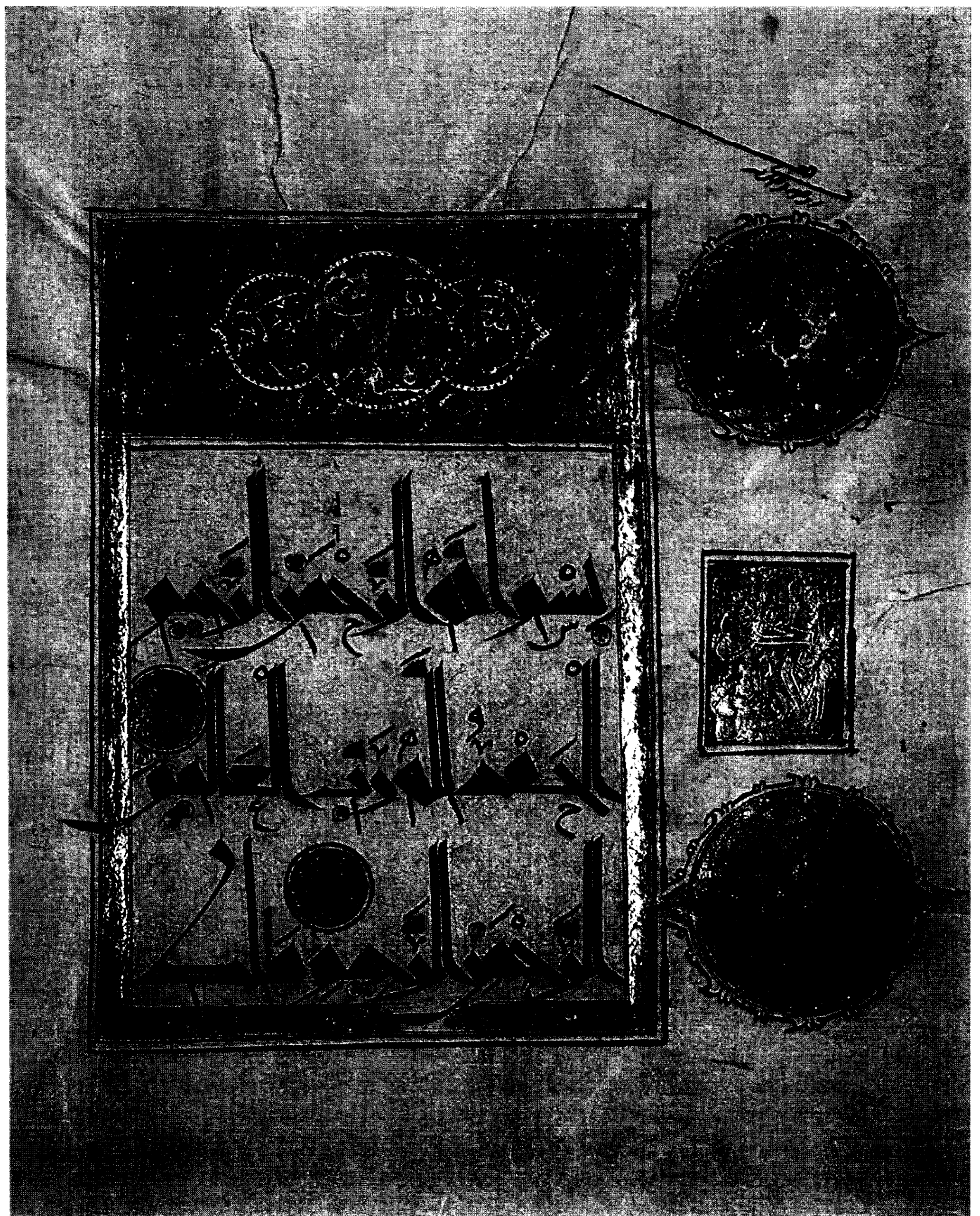


contained within an illuminated frame of Islamic patterns. The translation of the written language reads:

In the name of Allah, Most Gracious, Most Merciful. Praise be to Allah, the Cherisher and Sustainer of the worlds; Most Gracious, Most Merciful; Master of the Day of Judgment. Thee do we worship, and Thine aid we seek. Show us the straight way, The way of those on whom Thou hast bestowed Thy Grace, those whose (portion) is not wrath, and who go not astray. (Sura 1:1-7)

The Islamic patterns that surround the Qur'anic revelation are shaped by stylized plant forms, mainly long stems flowers tied together. The flowered patterns are interlaced with intricately constructed geometric patterns of a similar likeness. The patterns surround the calligraphy are representative of the natural world. 48 The reciprocal relationship formed between the Islamic patterns and the Kufic calligraphy reveals the images allegorical dimension, being the principle of unity between natural and divine worlds.

Kufic calligraphy consists of vertical lines intersecting with sporadically broken wavering horizontal lines. Alif, is the first letter in Allah. It is the origin of the alphabet and it is denoted by a vertical line. ${ }^{49}$ Both the position of alif, at the beginning of the alphabet and the vertical form of the character pointing at the heavens, give the character a connotative dimension. Alif is the origin of creation and, therefore, metaphorically represents $\mathrm{God} . \mathrm{Ba}$, the second letter in the alphabet, is denoted with a curved horizontal line. ${ }^{50}$ Nasr suggests ba created after alif, connotes humanity and the existence of the natural realm. The harmonious intersection of alif and ba reveal the allegory of unity at the foundation of the Islamic faith.

\footnotetext{
48 Seyyed Hossein Nasr. Islamic Art and Spirituality. (Albany: State University of New York Press, 1987) p. 29.

49 lbid, p. 30.

50 lbid, p. 31.
} 
Further, Kufic calligraphy reveals the Islamic notion of the void, a concept Nasr believes influences all aspects of Islamic material culture. "The use of the void in Islamic art is one of the most important direct consequences for art of the metaphysical principle of Unity, for nearly every facet of Islamic art is in one way or another related to this principle and its ramifications in the world of multiplicity." 51 According to Islamic metaphysics, the void or nothingness is interpreted to be the shadow or echo of God. Because the void is transcendent, it draws awareness to its inversion or the natural realm. Kufic calligraphy illustrates divine revelation and thus represents divine presences or void in the world. ${ }^{52}$ The edges of the black ink letters that give shape to Islamic revelation form a horizon between the material space of the natural world and the void space of God. The notion of the void illustrated in the "The Opening" is a spatial idea that is applied to both the rendering of the surfaces and the organizational structures of Islamic architecture (Fig. 5).

51 Seyyed Hossein Nasr. Islamic Art and Spirituality. (Albany: State University of New York Press, 1987) p. 185. 52 lbid, p. 186. 

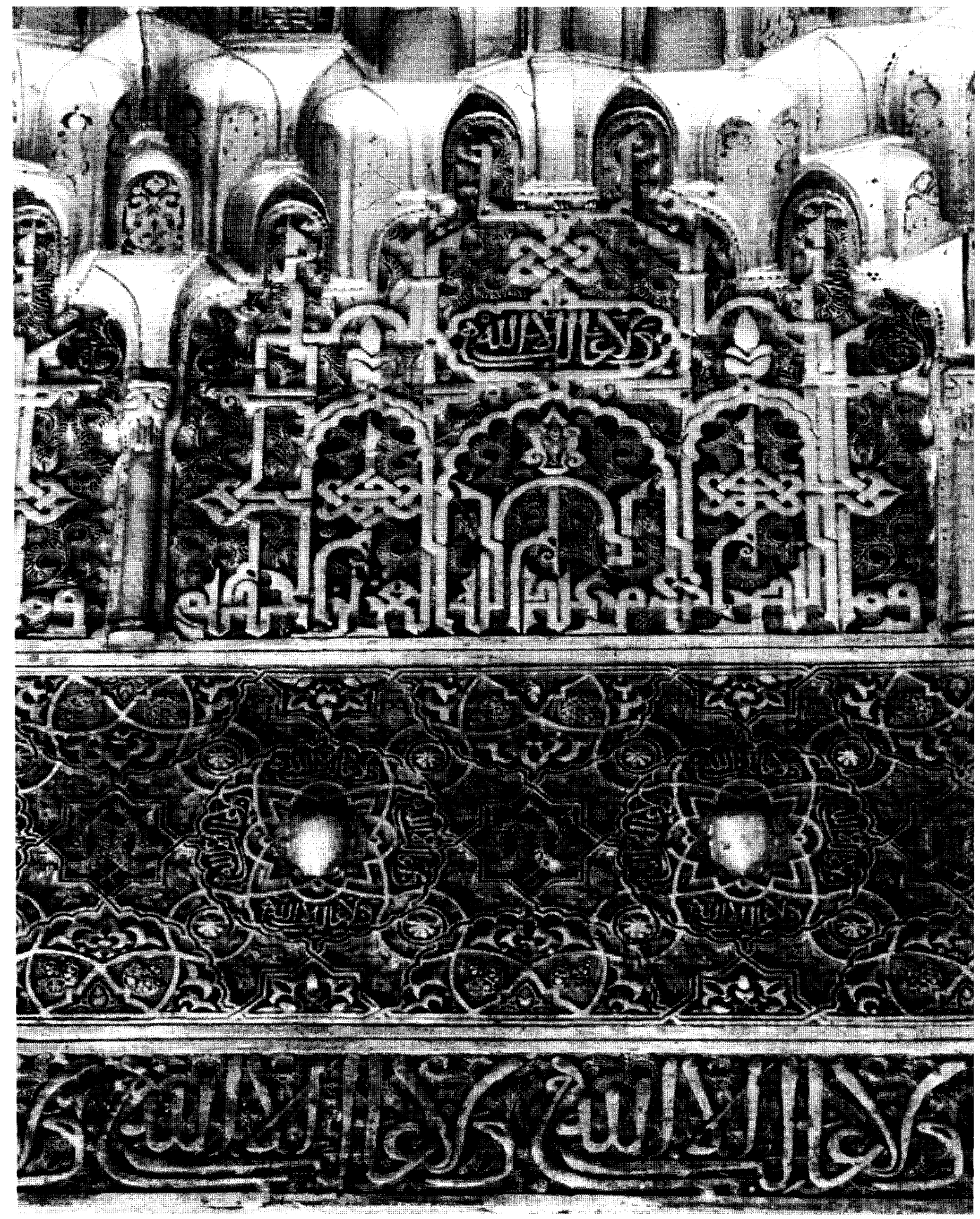


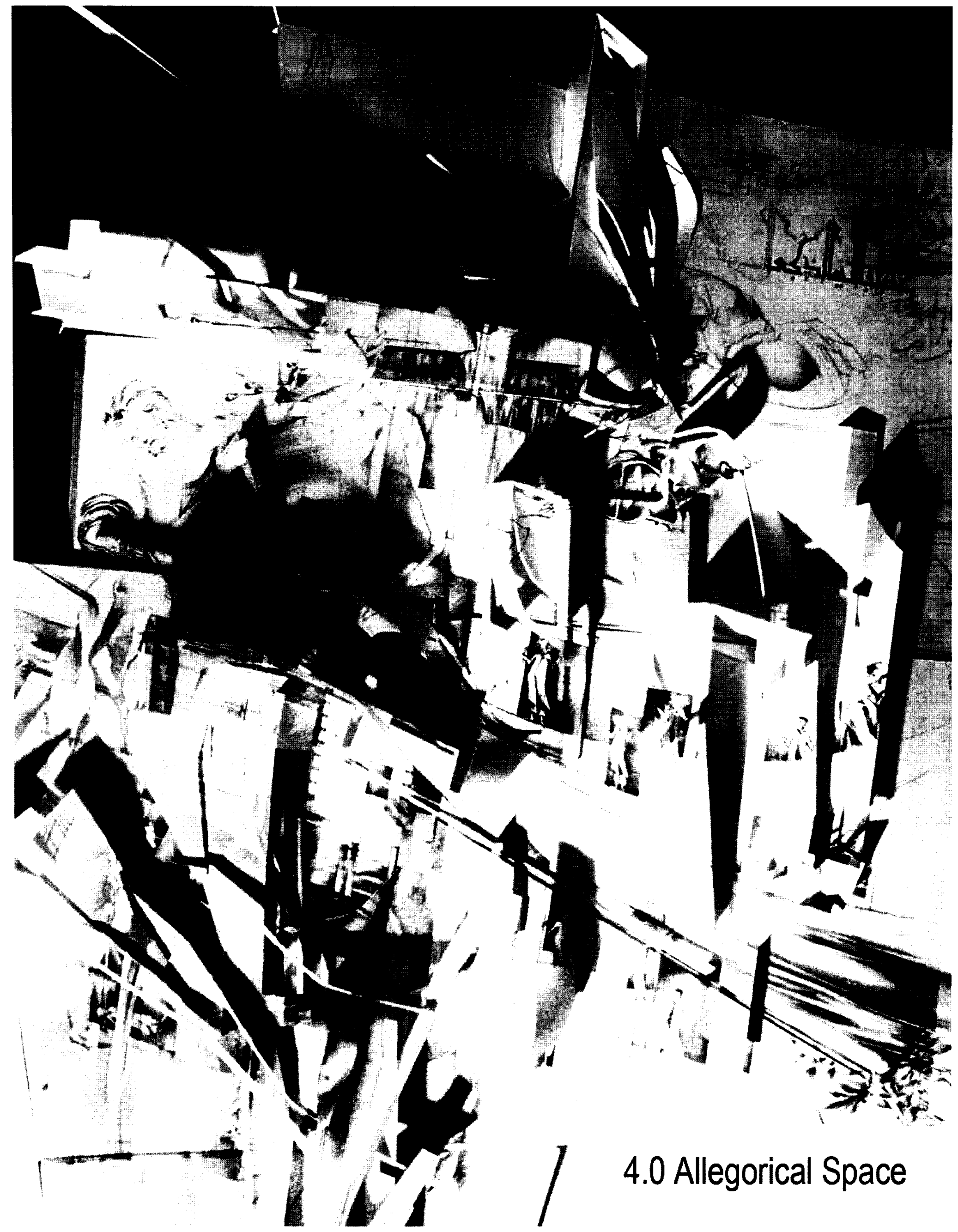




\subsection{Allegorical Space:}

\subsection{The Latent Architecture of the Abrahamic Faiths}

Within the early images of the Abrahamic faiths there is a latent architecture- an allegorical space resulting from the fusion of architectural space and the space of Abrahamic allegorical imagery. Abrahamic allegorical space represents the collapse of boundaries separating Abrahamic theology and the material context that surrounds it; allowing the believer to reside in mundane and sacred realms simultaneously. Abrahamic architecture is the simultaneous presence of material and allegory.

The Hebrew's production of allegorical space, conceivable once the Torah was realized, is, in part, a reaction to the ideological space of the world around them. Their creation of an allegorical space in which an alternative reality could unfold begins a pattern that repeats through the Abrahamic tradition. Abrahamic architectural development is not isolated as a separate form of theological representation, it was fused with imagery. Thus, the material dimensions of architecture and the imaginary depth of Abrahamic imagery collapse into a form of representation that includes the physical and imagined realms of the Abrahamic universe. The interwoven composition of the two mediums unfolds before the inhabitant, drawing one through architecture to reveal Abrahamic theology.

The Dura-Europos synagogue and house church and the Ka'ba are among the earliest known architectural artifacts of the Abrahamic traditions. Because the Abrahamic faiths emerged from within the architectural fabric of their host cultures, these early examples are all adaptations of existing structures. Once inhabited by the religious community they were adapted spatially through 
the use of imagery. The allegorical space of these Abrahamic architectures becomes evident when a plan and section is used to visualize both the material dimensions and the image dimensions of the architecture. Theses architectural drawings, which represent both physical and ephemeral dimensions of the artifacts, reveal the latent architecture within early Abrahamic imagery.

\subsection{Dura-Europos Synagogue}

During the sixth excavation campaign of the city of Dura-Europos in 1932-33, excavators working under Clark Hopkins uncovered a synagogue (Fig. 6,7). It would require the remainder of the campaign and an additional campaign to unearth the entire synagogue and realize the historical implications of their find. It was unthinkable at the time that a synagogue would contain any trace of imagery; Jewish scholarship maintained that the Second Commandment denouncement of images and material gods explained the nonexistence of Jewish imagery. ${ }^{53}$ Therefore it was not realized when the painted walls of the Jewish prayer hall were uncovered that it was in fact a synagogue. Once the Aramaic text residing at the feet of Moses was translated there was no question about the buildings identity. Michael White points out that the synagogue at Dura-Europos is not the only early rabbinic synagogue to have been discovered. To date six synagogues (Delos, Ostia, Sardis, Dura-Europos, Priene and Stobi) have been excavated, dating from the second century B.C.E. to the sixth century C.E. ${ }^{54}$ All of the aforementioned synagogues are adaptations of existing structures, five of which are converted from private houses. Ostia and Sardis synagogues both display modest Jewish markings which predate fifth century synagogue

\footnotetext{
53 Ann Perkins. The Art of Dura-Europos. (London: Oxford University Press, 1973) p. 55.

54 Michael White. The Social Origins of Christian Architecture. (Valley Forge: Trinity Press International, 1990) p. 62.
} 


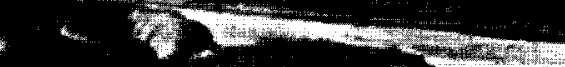

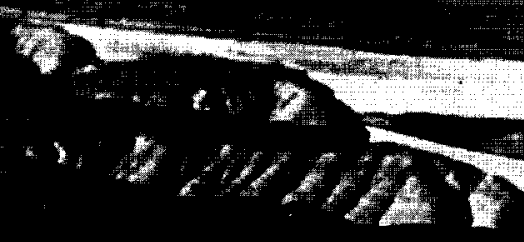

-3.

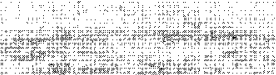

M.

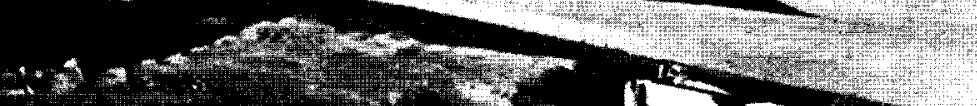

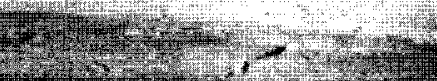

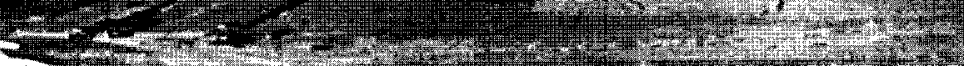

4
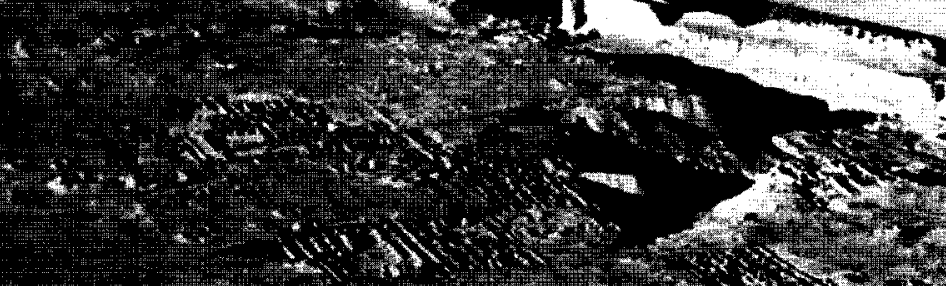

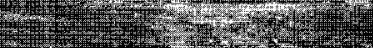
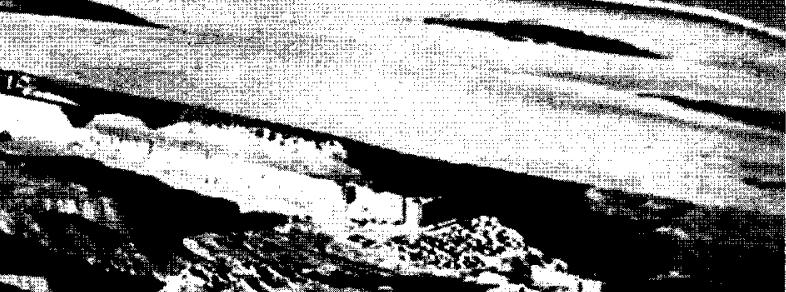

f

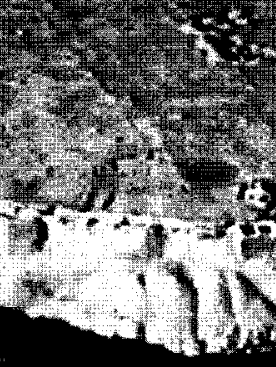

$-2+3 \times+30$
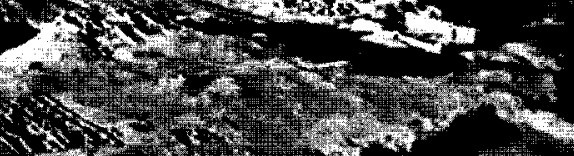

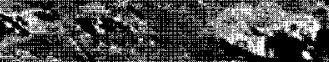

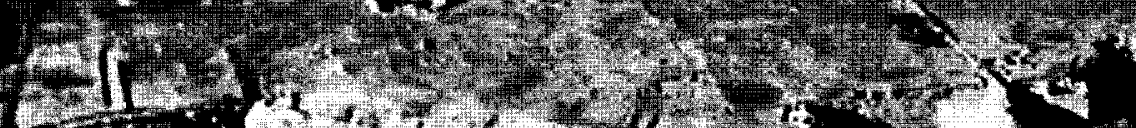

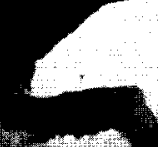

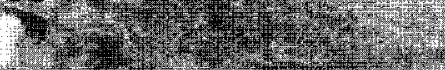

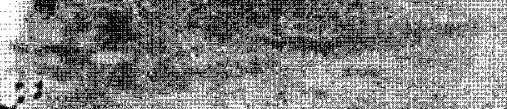

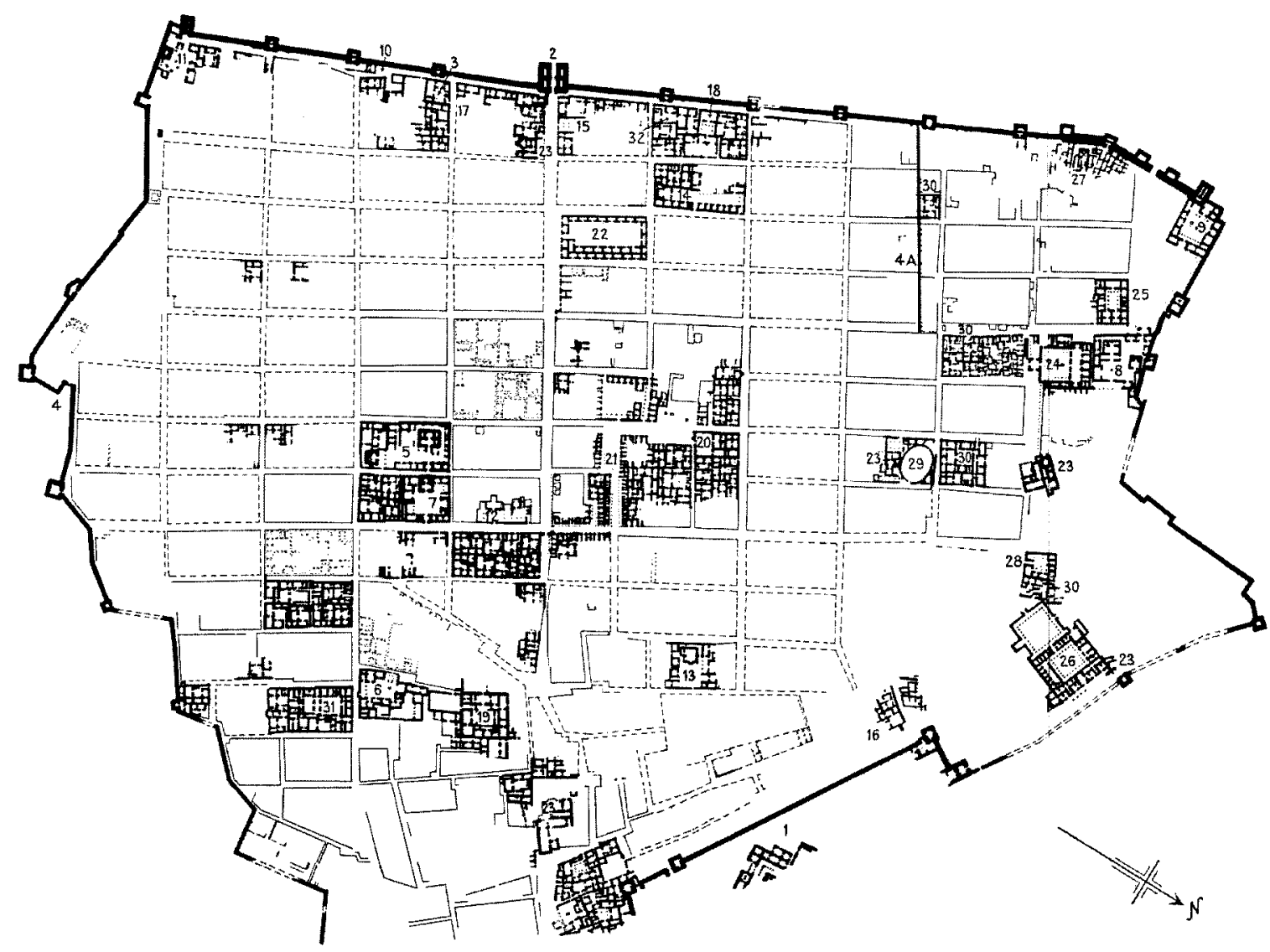

I. Citadel and its palace

3. Subsidiaty gate on the desert front.

4a. Brick wall of the Roman Military
Camp.

TEMPLES

5. Ternple of Artemis-Nanaia.

Zeus Megistos

8. Azzanathcona.

ro. Zets hyrios.

Ir. Aphlad. Gadde.

13. Zeus Theos

I5. Tyche.
i6. Military chapel.

17. Christian church
I8. Synagogue.

PUBEIC BUILDINGS

9. Acropolis Strategion.

20. Agora.

22. Khan.
2.3. Baths.

MILITARY BUILDINGS

24. Praetorium

25. House of a Higher Officer.

27. Mithraeun.

29. Amphitheatre

3\%. Barracks.

3r. House of Lysias.
32. House of the Scribes.

Yale: The excavated buildings are shown in plaa.
The excanated streets are sbown with solid

ond ulines.
The dites.

Fis. 6. PLAN OF THE CITY OF DURA IN PARTHIAN AND ROMAN TIMES

Fig. 6 


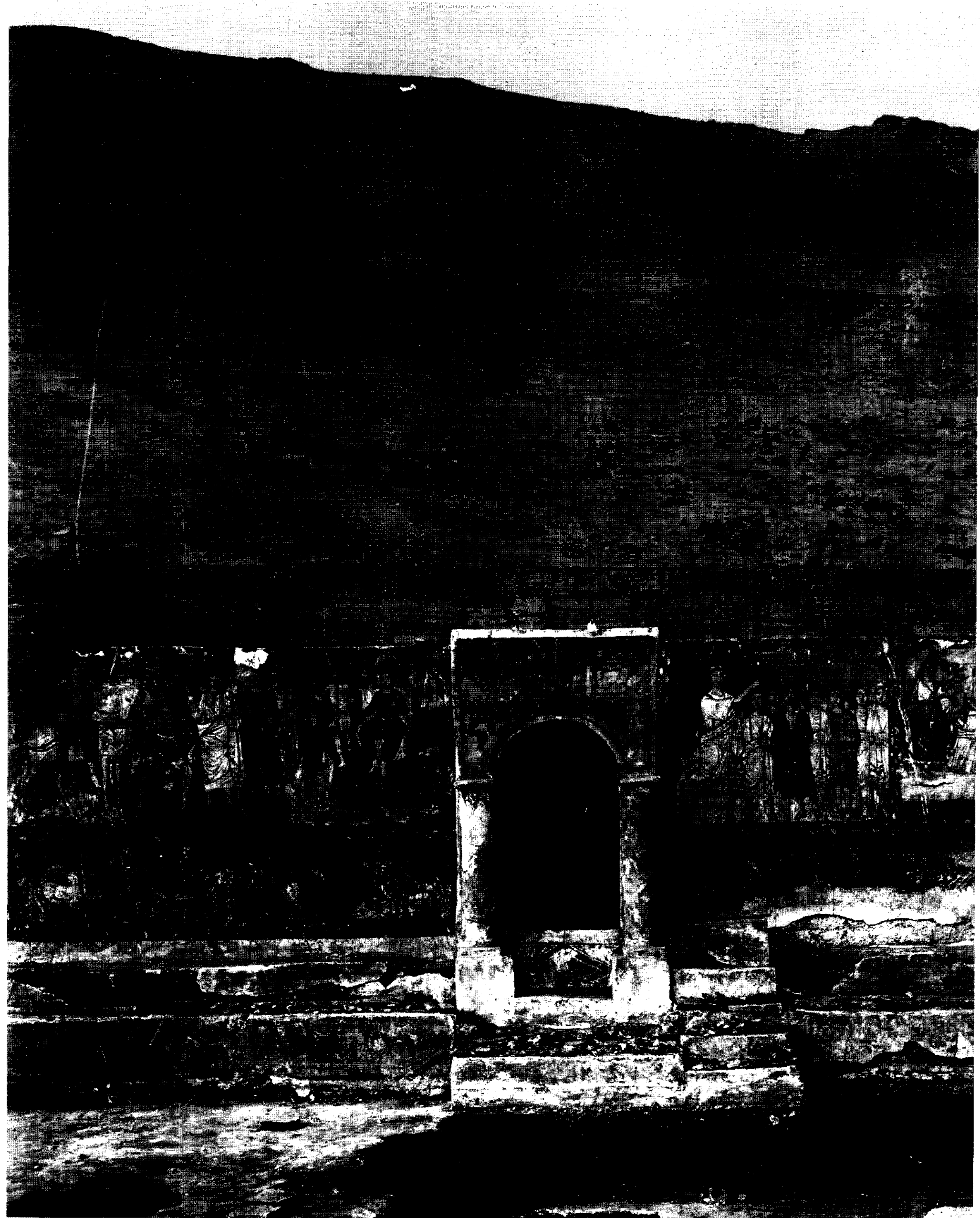


mosaics at Zippori, Tiberias-Hammat and Beit Alpha; however the wall paintings at the DuraEuropos synagogue remain the most extensive work of early Jewish painting discovered.

The synagogue was originally constructed as a typical Durene house (Fig. 8). Because no written records were found in Dura-Europos, it remains unclear when the Jewish congregation obtained possession of the house. It is also difficult to determine whether the house was used as a prayer hall prior to the first renovation. Without the proper documentation, scholars may never be able to date when the building was first used as a place of Jewish Worship. Given the archeological information available, White contends that the earliest the building can be accurately dated as a place of Jewish prayer is between 150-200 C.E., after the house had been renovated to include a large assembly space for prayer (Fig. 9). ${ }^{55} \mathrm{~A}$ niche set within the south-west wall of the prayer space terminates an axis aligning the halls central doorway with the courtyard of the synagogue and the city of Jerusalem. An alignment of the Torah niche and Zion was not consistent among the early synagogues, although after the destruction of the Second Temple (Temple of Zerubbabel and Herod) and the Bar Kochbah revolt it became a frequent practice. ${ }^{56}$ The synagogue in Delos is thought to be the only unearthed prayer hall to predate the fall of the Second Temple. Absent from the Delos synagogue along with a Torah niche are distinguishable Jewish markings and a consciously designed orientation. This suggests that the Torah niche did not assume the symbolic role of housing the revelation of God and orienting prayer until the Second Temple was in ruin. ${ }^{57}$

\footnotetext{
55 Michael White. The Social Origins of Christian Architecture. (Valley Forge: Trinity Press International, 1990) p. 74 56 Ibid, p. 66.

57 ibid, p. 62.
} 


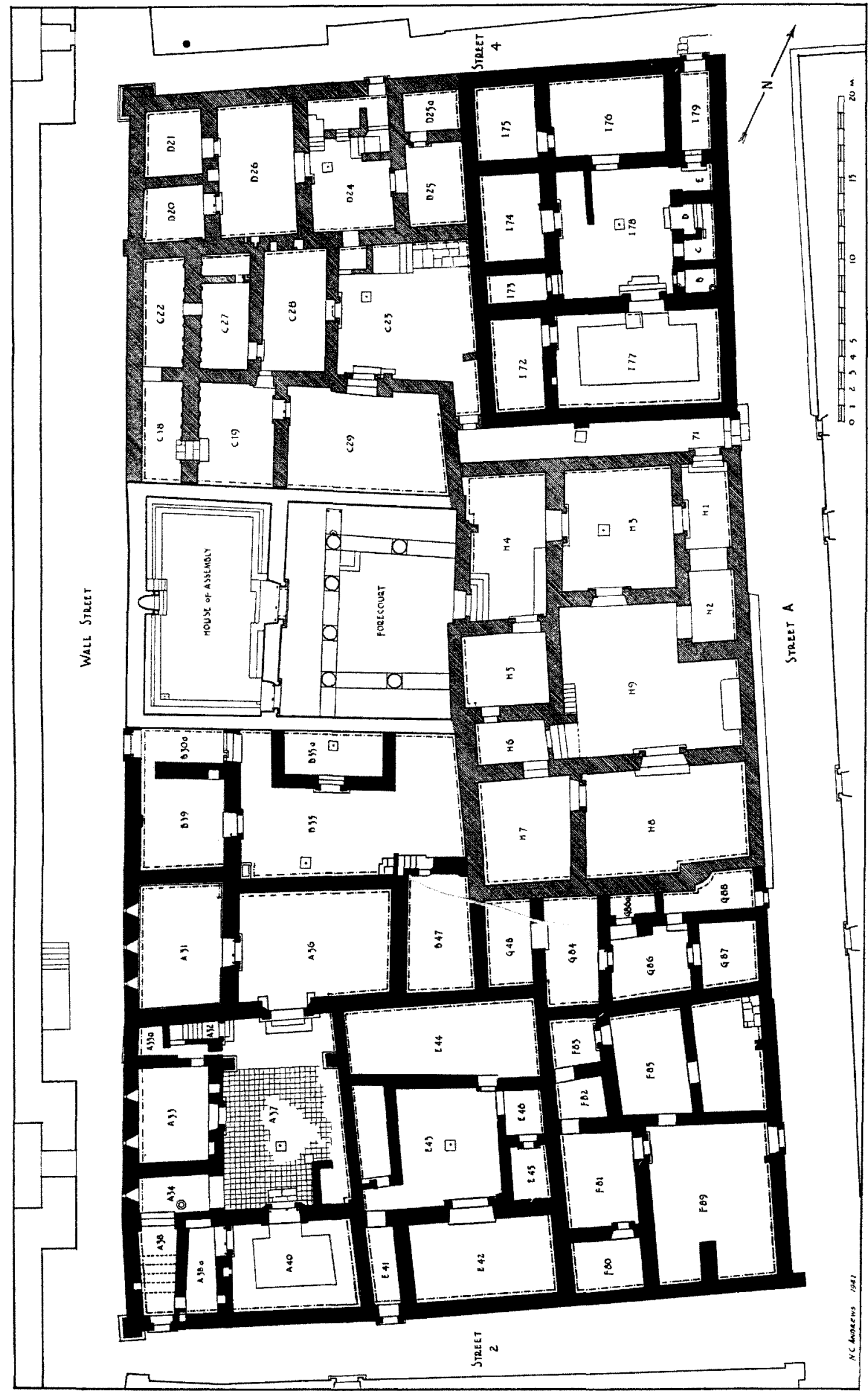

Fig. 8 


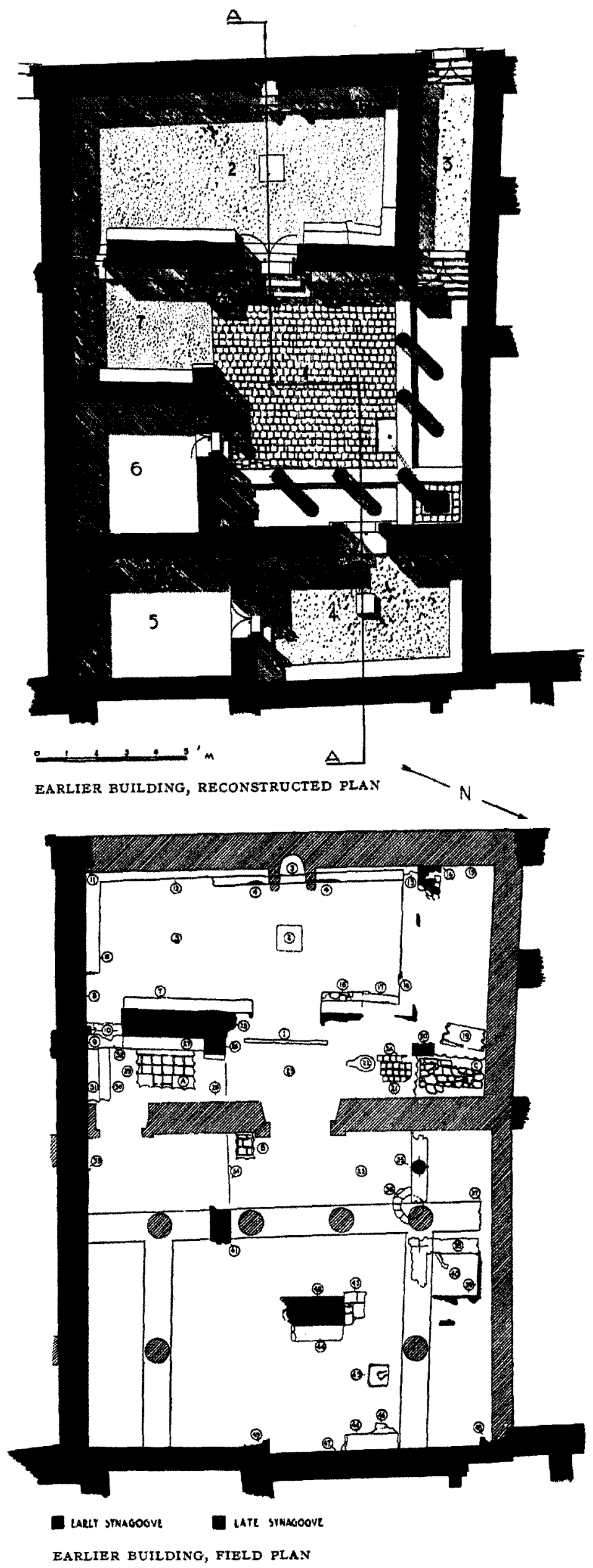

Fig. 9

Reproduced with permission of the copyright owner. Further reproduction prohibited without permission. 
Alterations to the original Dura house design between $150-200$ C.E. were restricted to the interior of the synagogue and it was not until the second renovation that the exterior of the edifice was affected. During the second renovation, the south-west wall of the synagogue, where the Torah niche was placed, was demolished and replaced with a thicker wall. ${ }^{58}$ Painted plaster fragments from the west wall housing the original Torah niche were used to make the perimeter benches during the second renovation. M. Rostovtzeff's description of the synagogue prior to the second renovation reconstructs the plaster remains of the prayer hall. According to Rostovtzeff between the first and second renovations the walls of the prayer hall were covered in ornamental paintings. ${ }^{59}$ Ann Perkins elaborates on Rostovtzeff's description and states that the walls were divided into three registers; the bottom was painted as panels of marble, the middle register contained patterns, and the top register remained white plaster. The ceiling of the prayer hall was painted as coffers with inlayed gilded rosettes. Adjacent to the prayer hall was a room for women, both the upper walls and the ceiling were painted with floral patterns and fruit. 60 Neither the wall paintings in the prayer hall or the side rooms contained Jewish figures or allegories. However it is evident that imagery was used in the composition of Jewish space as early as the first renovation of the Dura house.

The second renovation of the Dura-Europos synagogue included the previously mentioned removal of the west wall, as well as the majority of interior partition walls that formed rooms off the central courtyard (Fig. 10,11). The size of the prayer hall was increased to occupy the space where the former entrance was off Wall Street, and a new tiled ceiling was constructed at a height

\footnotetext{
58 Michael White. The Social Origins of Christian Architecture. (Valley Forge: Trinity Press International, 1990) p. 77 59 M. Rostovtzeff. Dura-Europos and its Art. (Oxford: Clarendon Press, 1938) p. 104.

${ }^{60}$ Ann Perkins. The Art of Dura-Europos. (London: Oxford University Press, 1973) p. 56.
} 


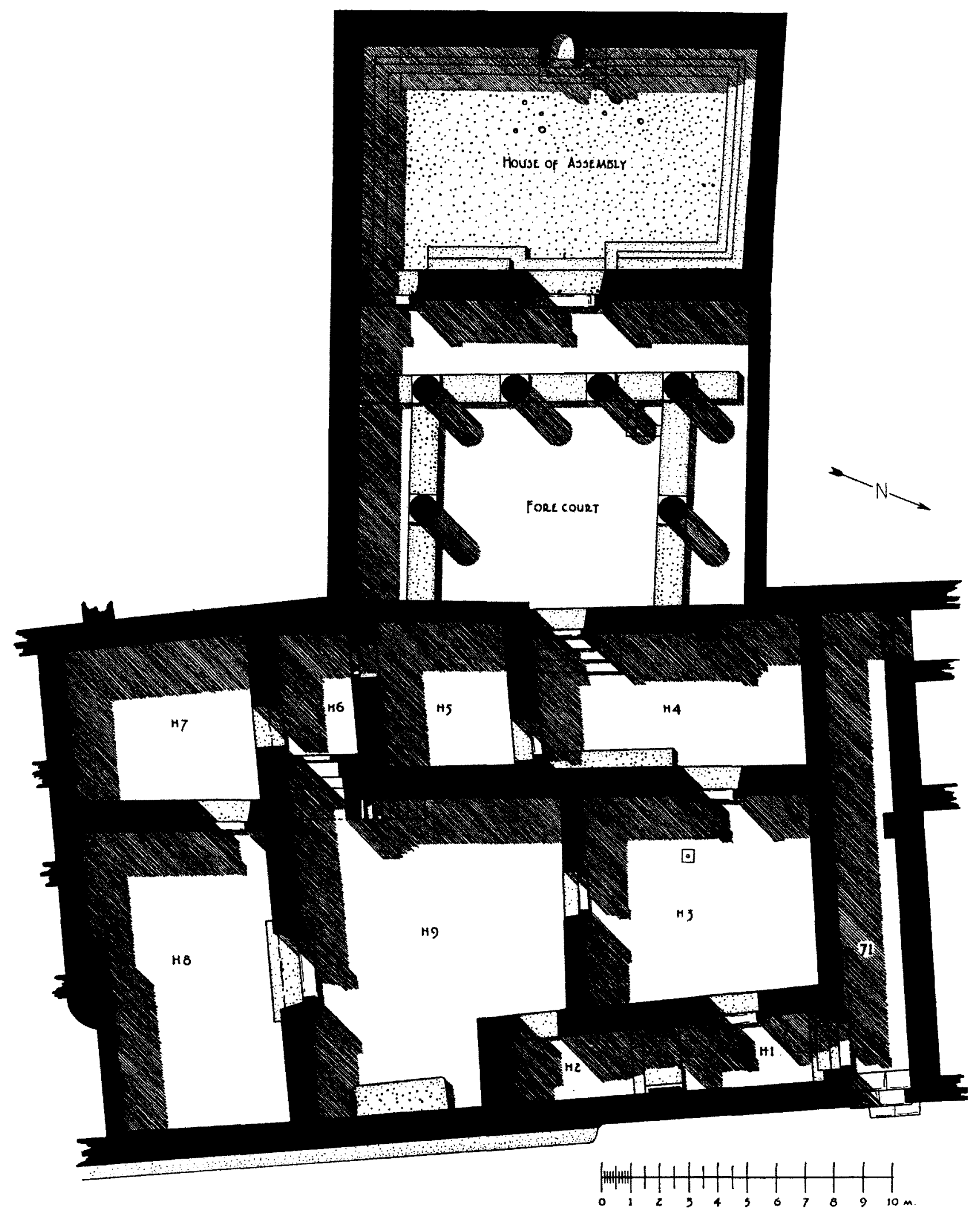

HOUSE H AND SYNAGOGUE, RECONSTRUCTED PLAN 


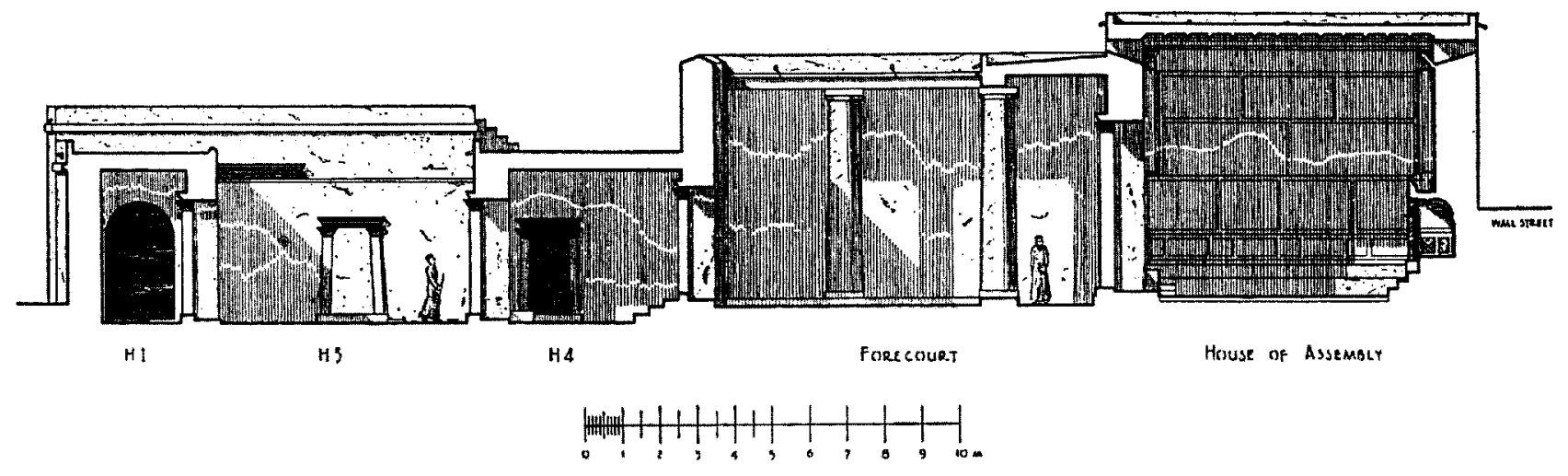

HOUSE H AND SYNAGOGUE, SECTION

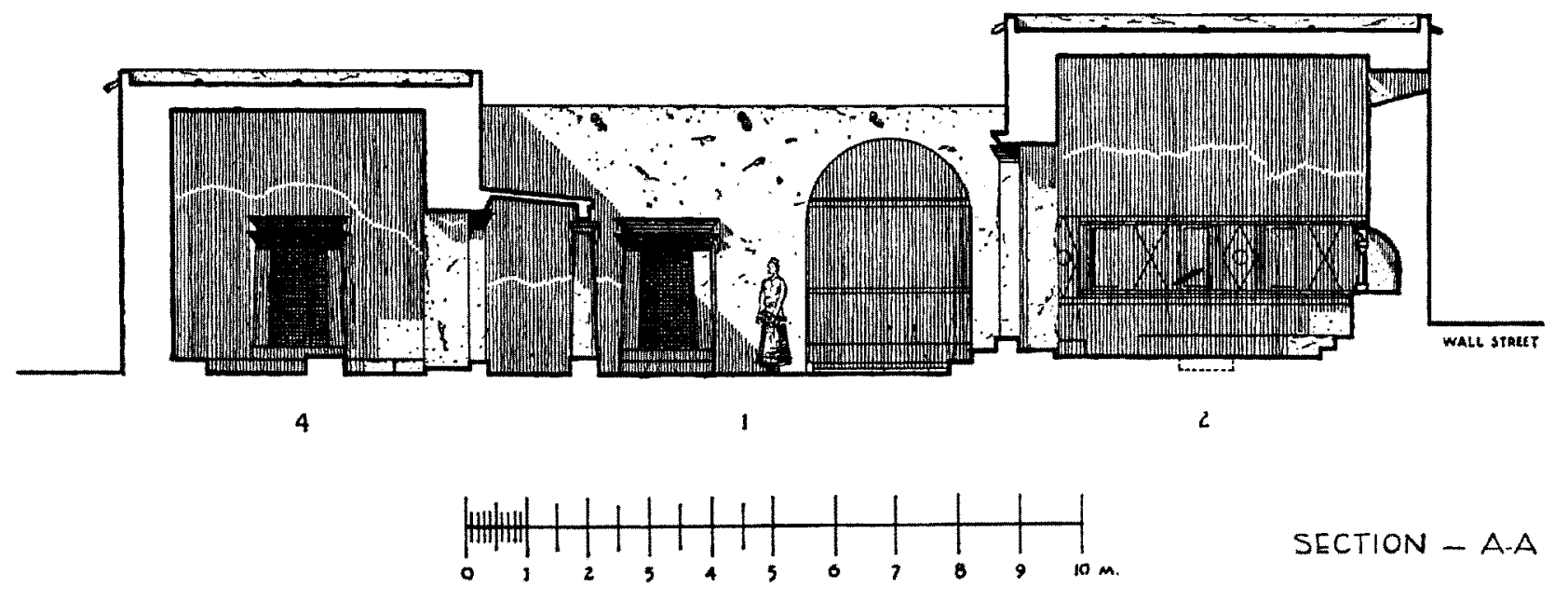

EARIIER BUILDING, SECTION

Fig. 11 
of six meters. The house located to the east of the synagogue, fronted on Street $A$, was bought and the entrance relocated to the east side.

\subsubsection{Allegorical Space of the Prayer Hall}

According to Rostovtzeff, at the time of the second renovation the walls of the prayer hall were unpainted save for the Torah niche and the aedicula (Fig.12). Small holes drilled in the walls of the aedicula suggest a curtain was hung, similar to the inner sanctuary of the Tabernacle (Exodus 26:33) and the Temple in Jerusalem (2 Chronicles 3:10-14) to conceal the Torah scrolls within the niche. ${ }^{61}$ The columns of the aedicula were painted to resemble marble while the facade was adorned with Jewish allegorical imagery. Centered above the arch of the Torah niche, is an image of a flat roofed columned building surrounding an arched doorway. The arch above the door in the image resembles the sculpted conch which forms the semi-dome of the Torah niche. It is accepted among scholars (Kraeling, ${ }^{62}$ Hopkins, ${ }^{63}$ Perkins, ${ }^{64}$ Wischnitzer, ${ }^{65}$ ) that the image represents the temple in Jerusalem. ${ }^{66}$ Hopkins draws an interesting comparison between the two images of the Jerusalem temple later painted on the wall behind the aedicula, both having sloped roofs, and the flat roofed temple painted on the aedicula. Perplexed by the contradictory images Hopkins proposes that the flat roof temple must either be the consequence of limited painting surface on the aedicula façade, or it refers to the cedar temple described in 1 Kings 6:9.67 In Hopkins' analysis the image of the Jerusalem temple is isolated from the aedicula, the architectural object on which the images is painted. If the allegorical space of the aedicula is

\footnotetext{
61 Clark Hopkins. The Discovery of Dura-Europos. (New Haven: Yale University Press, 1979) p. 144.

62 Carl H. Kraeling. The Synagogue. (New Haven: Yale University Press, 1979) p. 61.

${ }^{63}$ Clark Hopkins. The Discovery of Dura-Europos. (New Haven: Yale University Press, 1979) p. 144.

64 Ann Perkins. The Art of Dura-Europos. (London: Oxford University Press, 1973) p. 56.

${ }^{65}$ Rachel Wischnitzer. The Messianic Theme in the Paintings of the Dura Synagogue. (Chicago: University of Chicago Press, 1948) p. 88.

${ }^{66}$ Carl H. Kraeling. The Synagogue. (New Haven: Yale University Press, 1979) p. 61.

${ }^{67}$ Clark Hopkins. The Discovery of Dura-Europos. (New Haven: Yale University Press, 1979) p. 144.
} 


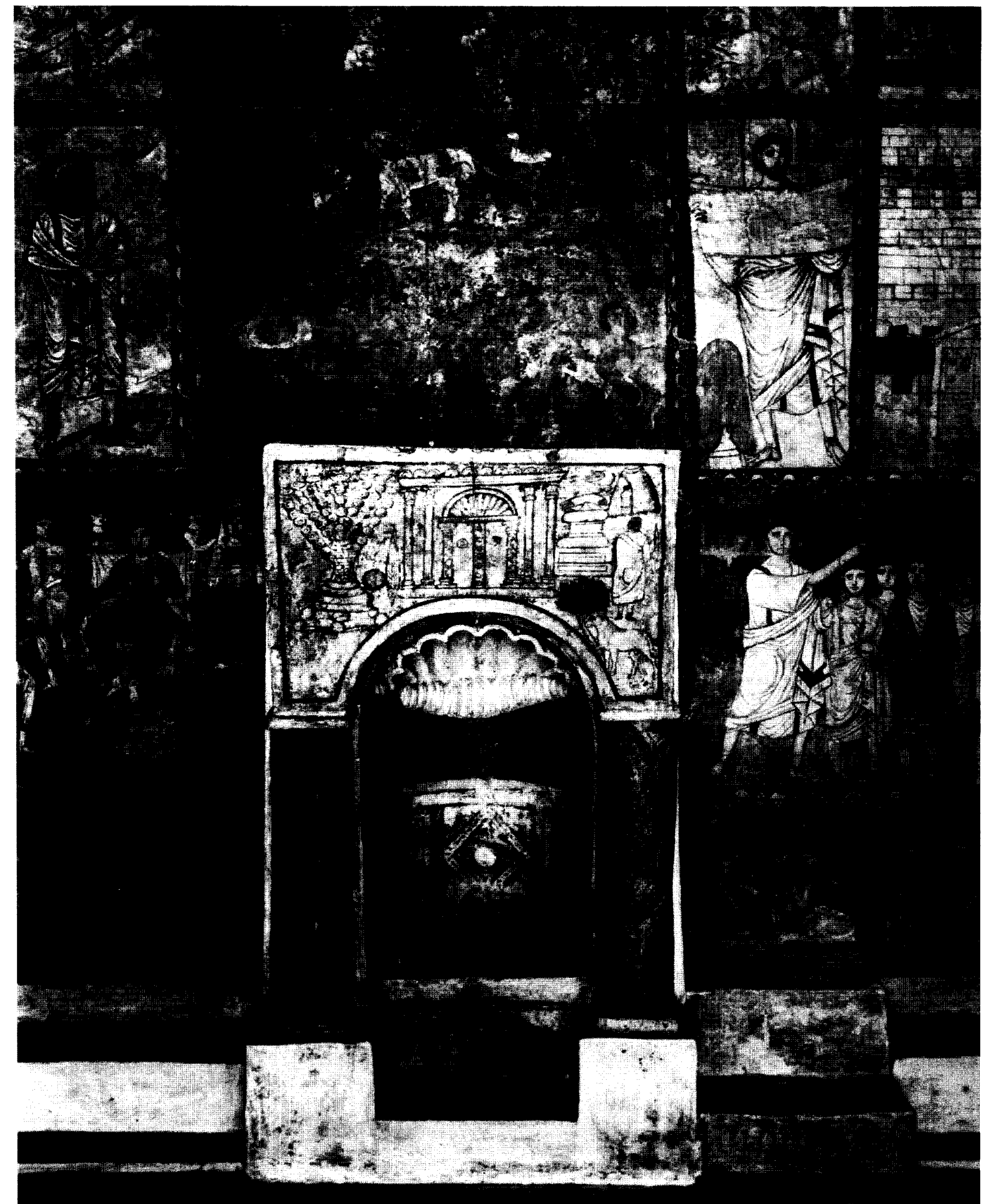


analyzed, the architecture of the aedicula and the image of the temple need to be viewed as one composition. Because the image of the Jerusalem temple is surrounded by other symbolic Jewish images, (menorah, citrus fruit, palm branch and the narrative of Abraham sacrificing Isaac) it is adorned with the authority of the temple. When the columned flat roofed image of temple is viewed as part of the aedicula it appears to depict not the Jerusalem temple but the Dura-Europos synagogue and its aedicula. The image on the aedicula façade could be an allegorical image; the self referential image attains authority through its juxtaposition with other symbolic images and passes authority to the architecture. According to Goodenough, who also argues against the Jerusalem temple interpretation, the image refers to a Torah niche surrounded with an architectural frame, similar to that of the funerary art found in Palestine. 68 Goodenough also suggest that the imagery painted on the aedicula may refer to heaven. The form of the aedicula and its material dimensions relate metaphorically to the Jerusalem temple while the dimensions of the image emphasize the role of Jewish Diaspora synagogue as the house of God's revelation.

Following the completion of the imagery on the aedicula, the walls which enclosed the Dura-Europos synagogue prayer hall were divided into four registers, three of which were covered with imagery depicting Torah narratives and allegories (Fig. 13). The images that remain on the prayer hall walls have fallen under the eye of numerous scholars. Weitzmann ${ }^{69}$ and Gutmann (The Dura-Europus Synagogue: a re-evaluation (1932-1992)) ${ }^{70}$ have focused their studies to determine the images ancestry, attempting to place illustrated manuscripts within the catalogue of early Jewish material culture. While other scholars, such as Goodenough (Jewish symbols in the Greco-

\footnotetext{
68 Goodenough, Erwin R. Jewish Symbols in the Greco-Roman Period volume 9. (New York: Bollingen Foundation, 1964) p. 69.

69 Joseph Gutmann. No Graven Images. (New York: KTAV Publishing House Inc., 1971) p. 310.

70 Joseph Gutmann. The Dura-Europus Synagogue; a re-evaluation (1932-1992). (Atlanta: Scholars Press, 1992) p. xxv.
} 


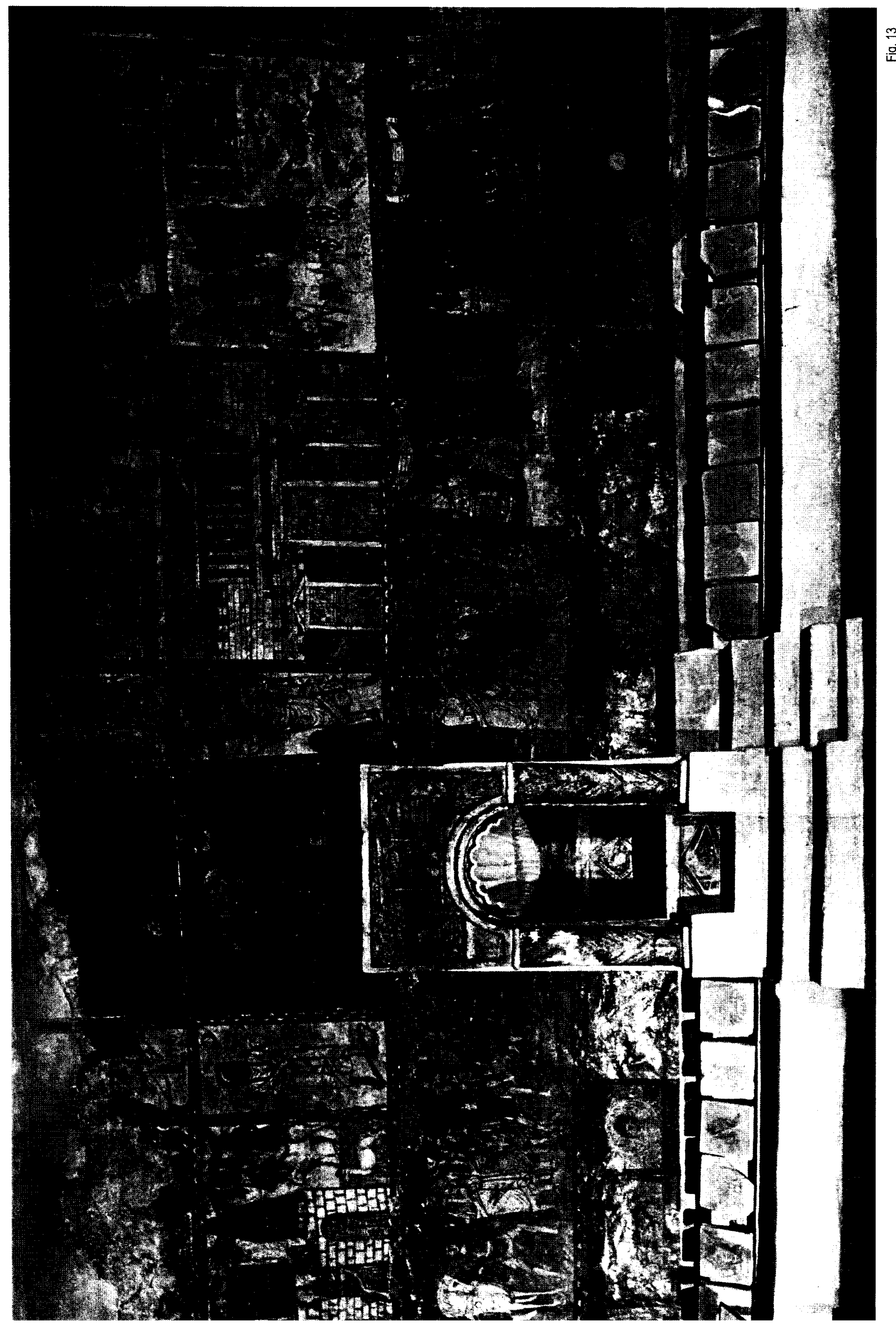

Reproduced with permission of the copyright owner. Further reproduction prohibited without permission. 
Roman Period) and Wischnitzer (The Messianic Themes in the Paintings of the Dura Synagogue) have investigated the collective meaning or messages found within the composition of the individual images. In addition to these inquiries, the spatial aspects of the imagery and their relation to the synagogue architecture need to be analyzed in order to understand the DuraEuropos synagogue as an ideological representation of early Jewish culture and theology. To that end we will turn our attention to the spatial composition of the synagogue design.

The courtyard adjacent to the prayer hall is entered from the east on axis with Jerusalem and the Torah niche. There is an absence of imagery in the courtyard save for the animated portion of the sky above the synagogue framed by a perimeter colonnade. The mute expression of the courtyard allows ones gaze to be drawn toward heaven while their path aligns with Jerusalem, the city of God. Perceptually, residing between the ontological sphere of the divine and its earthly metaphorical counterpart one enters the prayer hall and is immersed in allegorical space. The painted imagery that surrounds the prayer hall is thought to have been created in multiple phases, which suggests that the synagogue was subject to ongoing adaptation. For instance opposite the central door on the west wall above the Torah niche the imagery appears to have been repainted on several occasions over the existing images. Uncovered during the excavation was painted clay tiles which formerly covered the surface of the ceiling, they are clearly dated 245 C.E. ${ }^{71}$ Whether the date on the tiles refers specifically to the painted ceiling alone or includes the wall paintings, is unknown, it likely refers only to the ceiling.

Adorning the wall above the aedicula, flanked by four portraits, is an image of a tree with vine branches, a common Jewish metaphor for the chosen people of God (Fig. 14). The absence

71 M. Rostovtzeff. Dura-Europos and its Art. (Oxford: Clarendon Press, 1938) p. 104. 


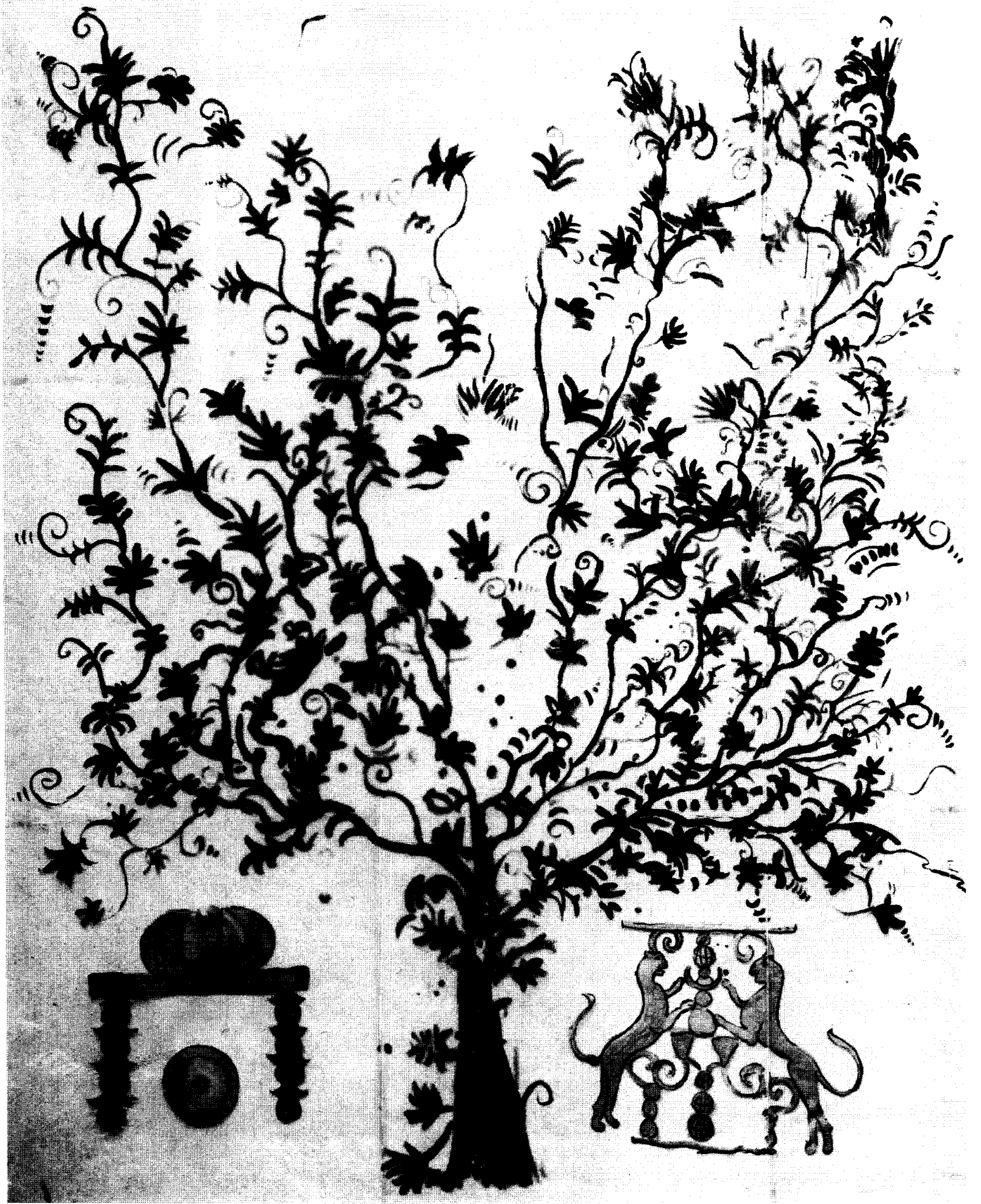

Fig. 14 
of grapes on the vines and the multiple holes found in the wall suggest that the plaster rosettes found on the floor of the synagogue were once ornaments on the tree. ${ }^{72}$ According to Kraeling, the 'tree of life' also refers to the Torah, which was appropriately placed within the Torah niche below. Moses receiving revelation from the burning bush (Exodus 3:2-6) and the law from Mount Sinai (Exodus 19) along with Abraham centered between the sun and the moon, and an open scroll held by Samuel frame the ornamented tree (Fig. 15). Extending outward in both directions from the centre panel along the middle register are representations of the Jerusalem Temple and the Tabernacle. To the north, the Temple is uninhabited and set within the seven walls of Jerusalem (2 Samuel 5:9, 1Kings 3:1). The Tabernacle to the south is occupied by Aaron and the priests along with the menorah and several other sacred articles (Exodus 35, 36, 37, 38, 39) (Fig. 16). Adjacent to the Temple image are images of the pharaohs daughter discovering Moses abandoned in the Nile river (Exodus 2:1-8) (Fig. 17) and Moses in the desert striking a rock to provide water for the Hebrews following their escape from Egypt (Numbers 20:5-12) (Fig. 1). On the opposite side, the ark is returned to the temple from the Temple of Dagon (1 Samuel 5:2-5). Also on the west wall, framed between the large painted columns that occupy the corners of the prayer hall, are scenes describing the Pharaoh's daughter discovering Moses in the Nile (Exodus 2:1-10) and Moses leading the Hebrews out of Egypt through the Red Sea (Exodus 12,13, 14). Beside the aedicula, Samuel anoints David with a horn of oil (1 Samuel 16) and the story of Elijah unfolds in multiple scenes.

The archeological remains of the synagogue matched the slope of the sand embankment wall they were incased within. As a result, the six meter high painted walls on the west side were preserved, while along the eastern edge, only one half meter was preserved. Despite the location

72 Carl H. Kraeling. The Synagogue. (New Haven: Yale University Press, 1979) p. 63. 

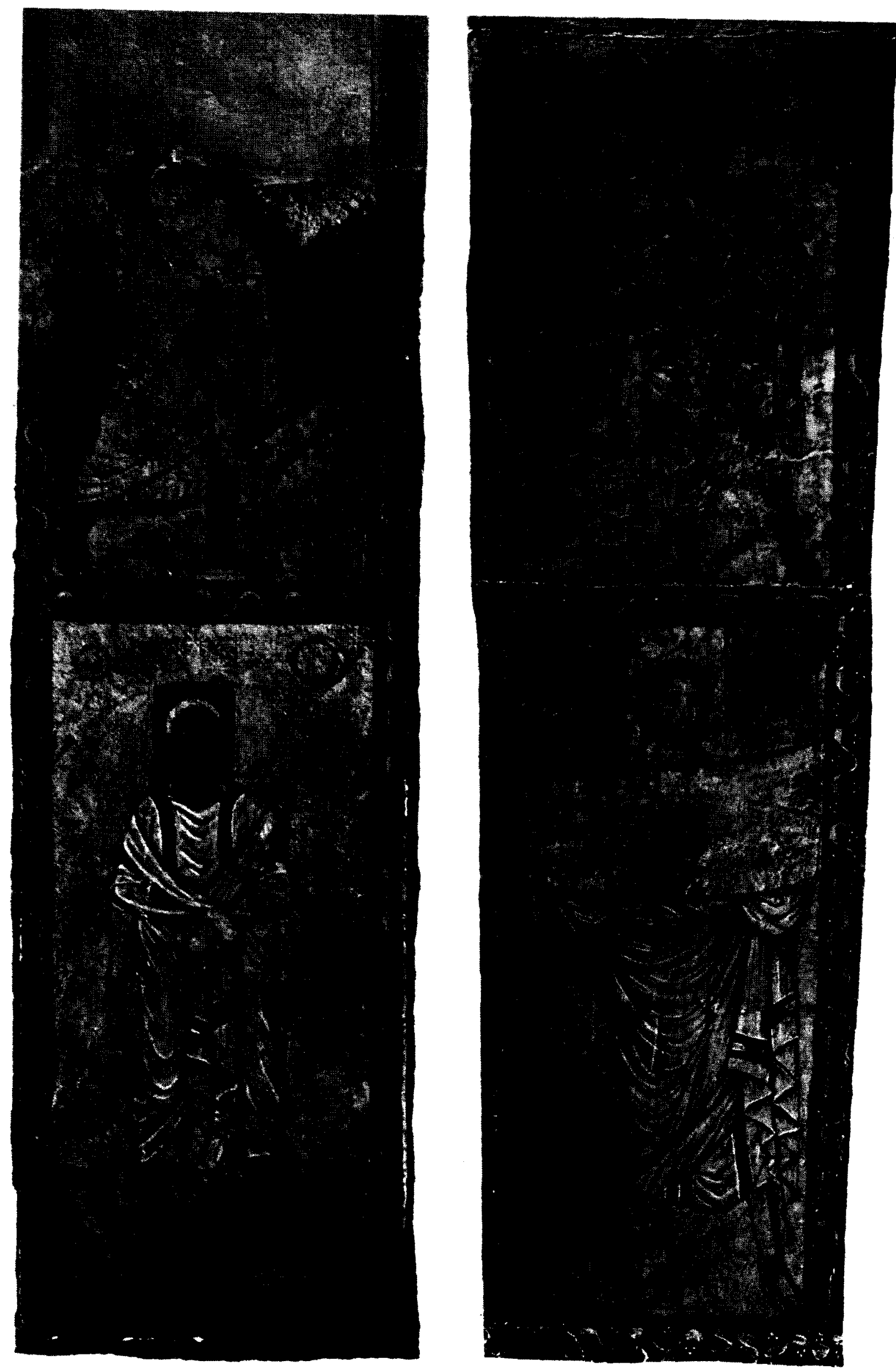

Fig. 15 


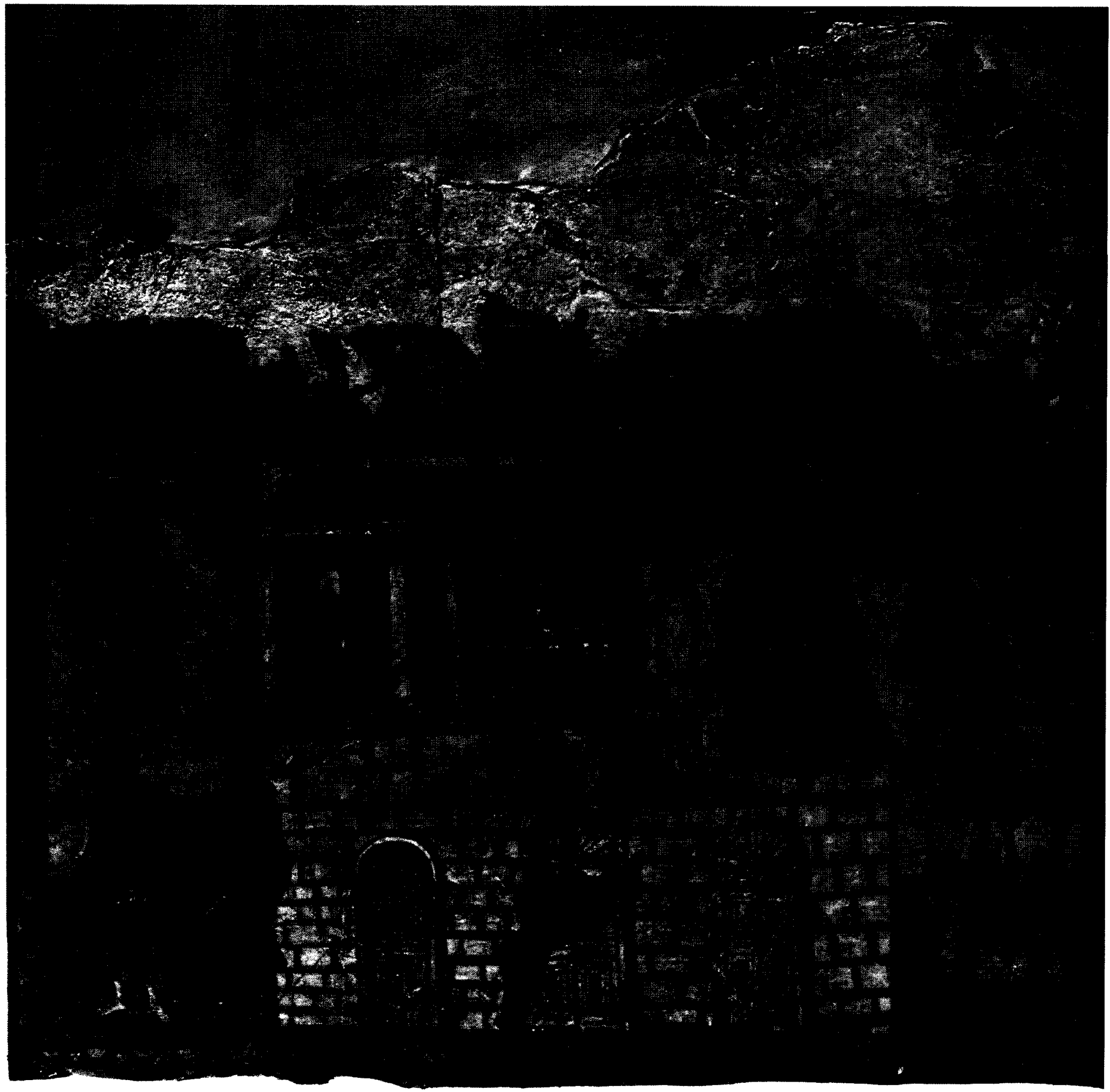

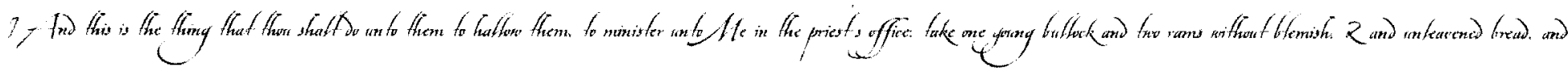

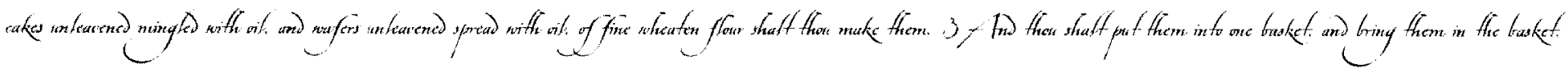

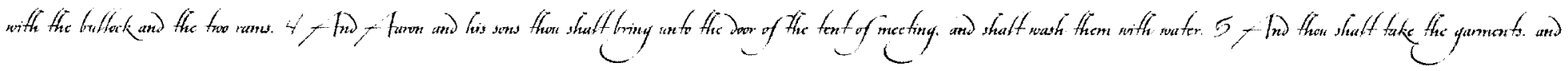

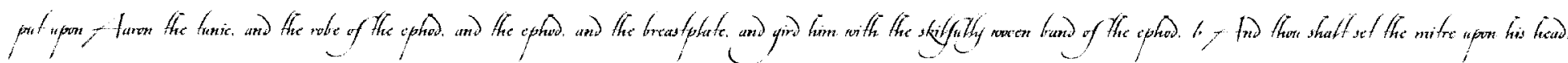

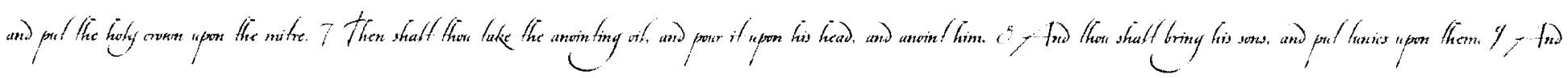

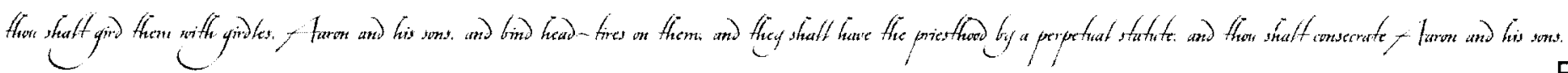




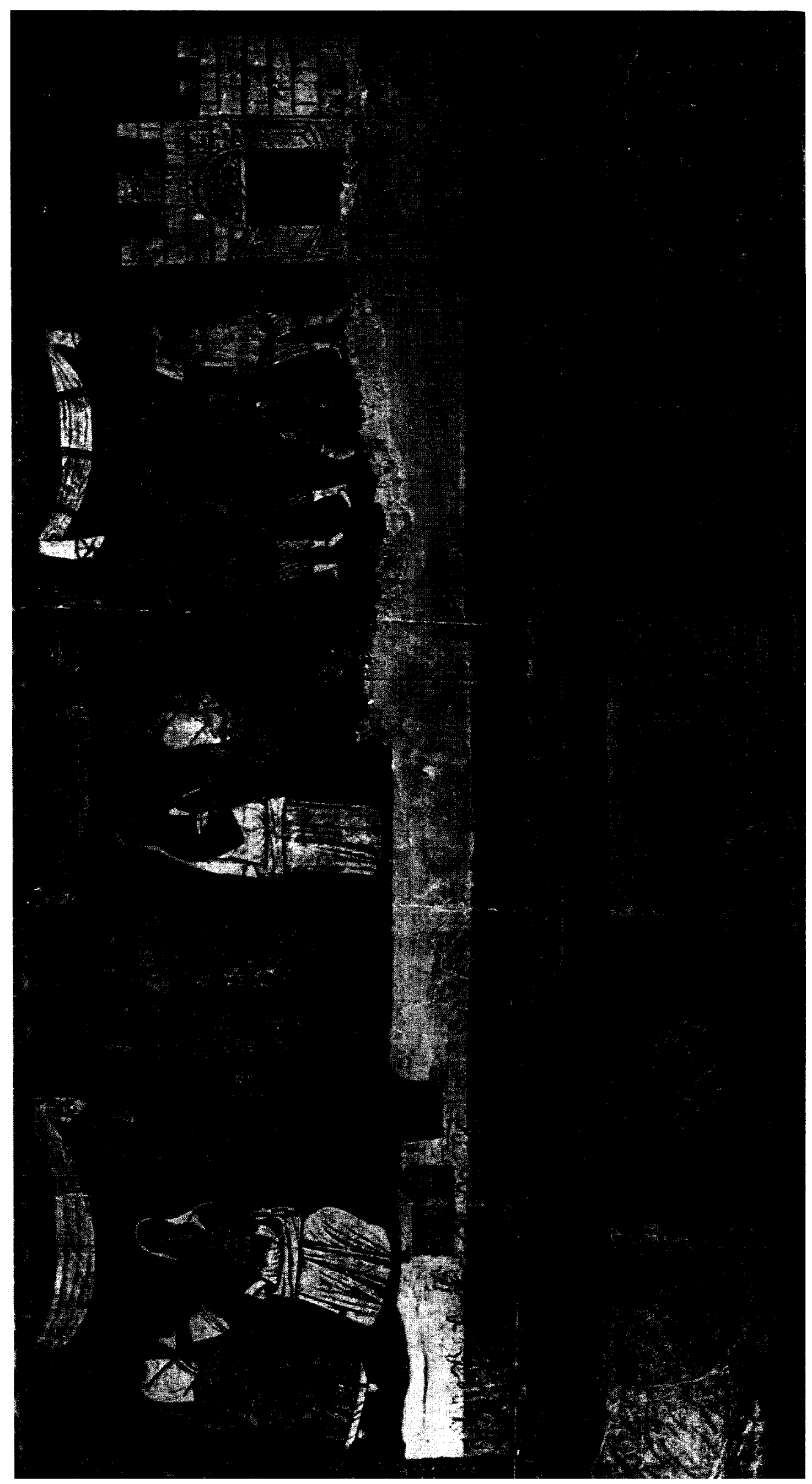


of the prayer hall along the west side of the synagogue, forty percent of the walls, along with their paintings, dissolved. The remaining fragmented walls on the north and south display the procession of the ark at the dedication of the Temple (2 Samuel 6:12-15, 1 Kings 8:1-11) and the ark in battle. Only the dado and the lower register remain on the east wall, divided by two doorways, one centered and aligned with the aedicula, the other offset to the south. Salvaged from the ruined east wall is an image of David and Saul in the wilderness of Ziph (1 Samuel 26).

\subsubsection{Representation of Allegorical Space}

The Dura-Europos synagogue paintings are not consistent in their style or form throughout the prayer hall; some scenes are illustrated with several images while others are contained within one frame. The inconsistence among the synagogue imagery points to the images development over time. The adaptations of the architectural elements of the synagogue were developed in relation to the synagogue imagery. Not unlike the limited delineation between literary types in the Abrahamic sacred texts the imagery of the synagogue represents a range of image styles and forms, arranged in accordance with architecture to collectively express Jewish theology. The continued spatial modification of the synagogue was a reconciliation of architecture and image. The respective boundaries were blurred and the dimensions, one being physical the other implied, fused to create allegorical space. The space of the synagogue represented the here and hereafter, containing space inhabited by the body and space inhabited through the imagination.

Perkins notes that: "Architectural representation plays a larger part in the synagogue paintings than others [temples] at Dura, and one panel shows only architecture."73 The attention devoted to architecture in the imagery of the synagogue suggests the importance of representing

${ }^{73}$ Ann Perkins. The Art of Dura-Europos. (London: Oxford University Press, 1973) p. 62. 
the sacred space of the imagination as a distinction between Jews and their pagan neighbors. The allegorical space of the synagogue is revealed when the material dimensions and the image dimensions are mapped as architectural plan and section drawings (Fig. 18). The allegorical space drawings represent both physical and ephemeral dimensions of the synagogue and are used to represent the hidden dimensions of the Dura-Europos synagogue.

\subsection{Dura-Europos House Church}

The Christian House Church at Dura-Europos shares a similar history with the synagogue. Unearthed by Clark Hopkins during the fifth excavation campaign in 1931-32, the House Church was discovered within the sand embankment wall that wrapped the perimeter of the city. Plaster remains found on the walls date the renovation of the Durene house at 232 C.E. (Fig. 19). It is questionable whether the house was built in 232 C.E. or if it records the date when the House was adapted into a House Church. An Alexander Severus coin (222-235 C.E.) found in the floor of the assembly space lead Kraeling to believe that the house was constructed in 232 C.E. and renovations followed some time after. ${ }^{74}$ Hopkins maintains that the 232 C.E date marks the renovation date.

Renovations to the original Durene house were modest when compared to the second renovation of the Dura-Europos synagogue. Unlike the synagogue the prayer hall or assembly space of the house church contained no trace of imagery. The only modification of note in the assembly space was the removal of a wall which formerly divided the space into two rooms. Significant adaptation occurred across the courtyard from the assembly space in the baptistery. The walls and ceiling were adorned with Christian imagery and a baptismal font was built.

${ }^{74}$ Clark Hopkins. The Discovery of Dura-Europos. (New Haven: Yale University Press, 1979) p. 95. 

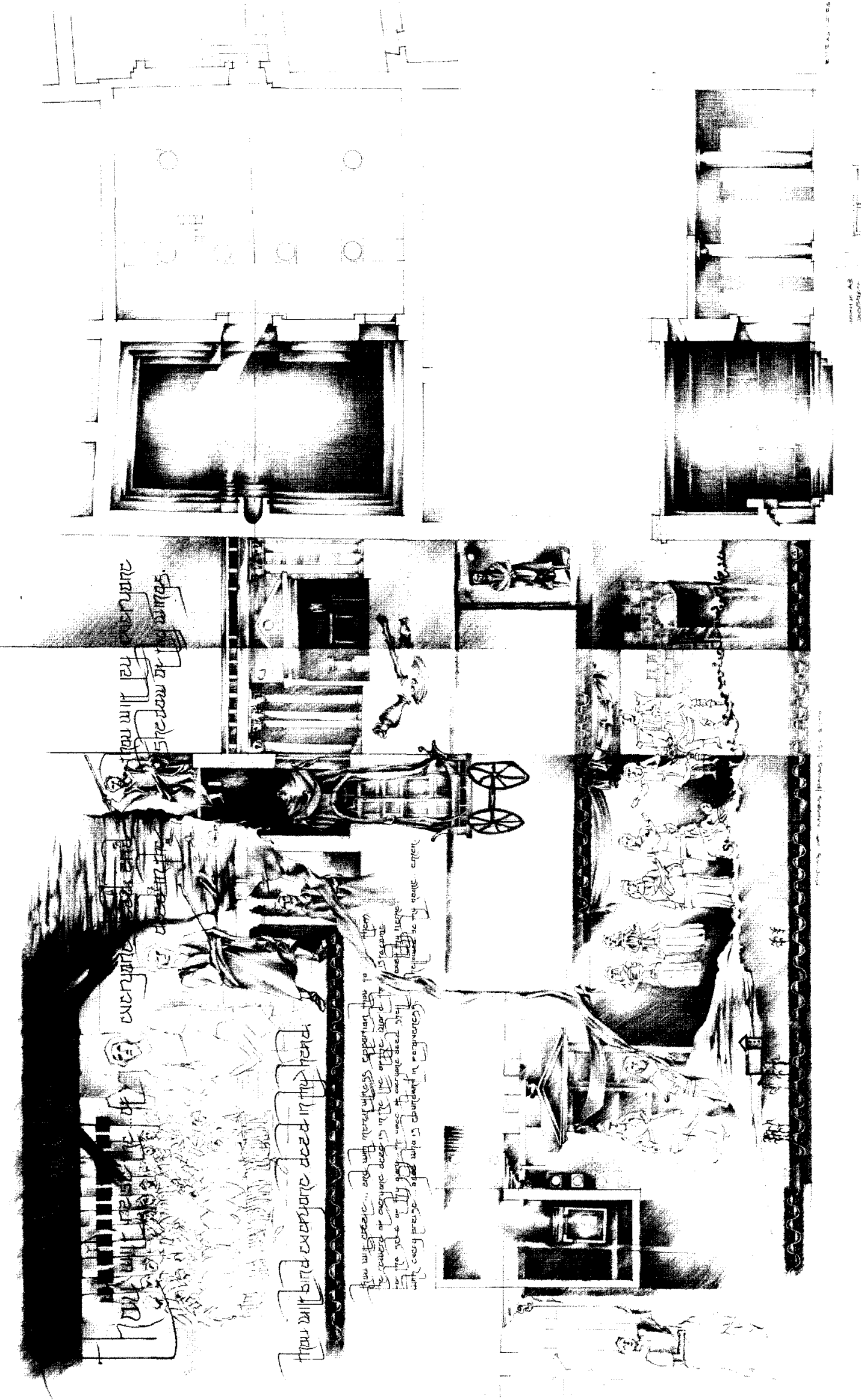


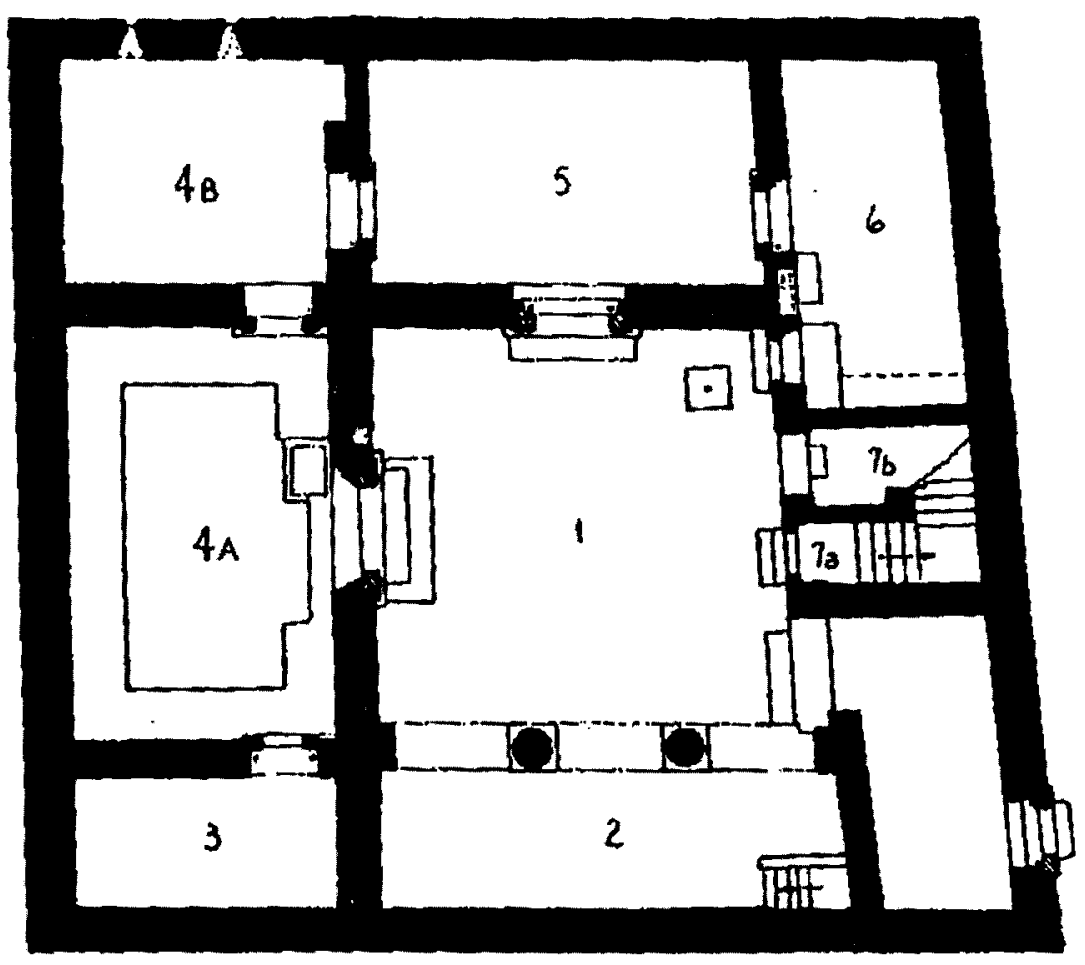

a. Before renovation

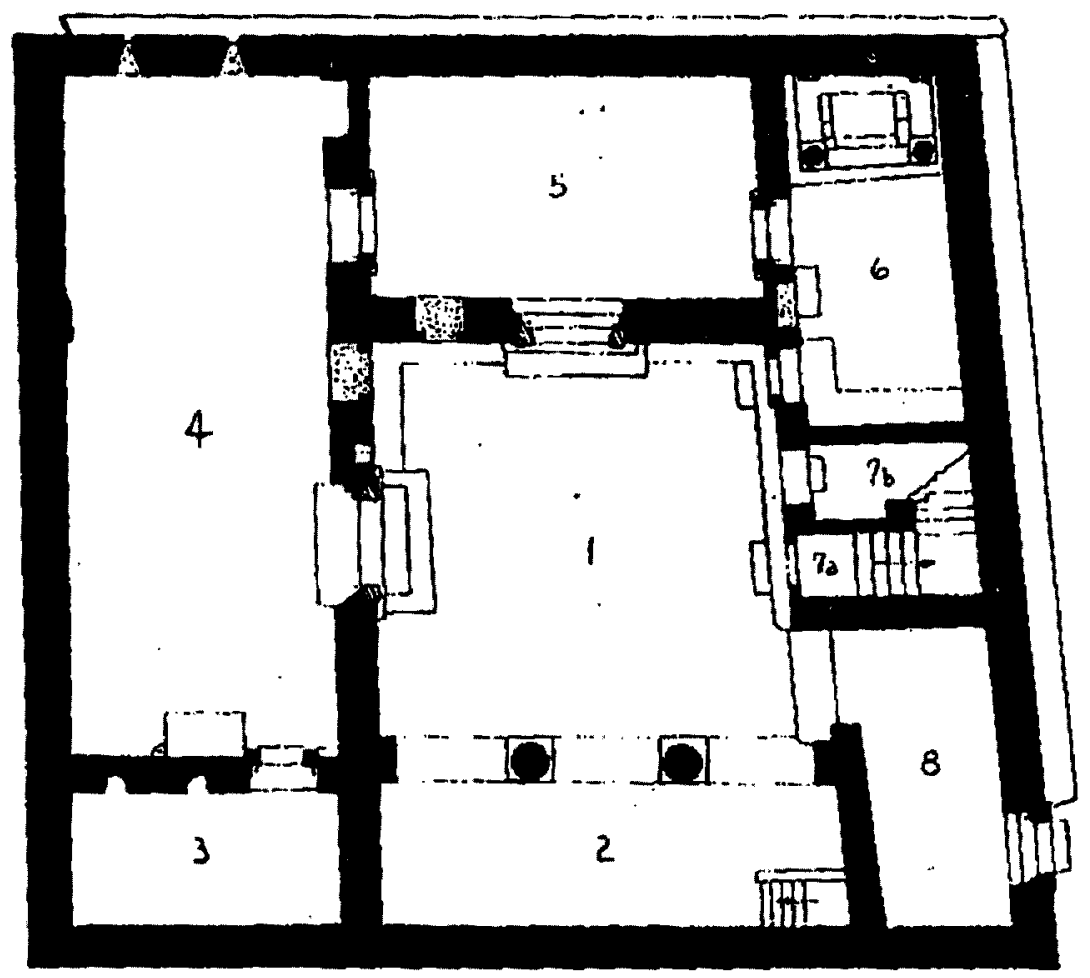

b. After renovation 


\subsubsection{Allegorical Space of the Baptistery}

The baptistery of the Dura-Europos House Church can be entered through two doors, one leads from the courtyard centered in the church plan, while the other opens onto an adjacent room. The baptismal font is constructed in a similar manner to the aedicula found in the synagogue but is about twice as large. It occupies the entire west wall and roughly a third of the space of the baptistery. Stone steps lead to a depression within the base of the baptismal font which is assumed to have been filled with water. A pair of columns painted to resemble marble rise from the stone base and support a vault which encloses the space of the font. The arched façade of the baptismal font bares symbolic imagery of fruit and grapes, while the vault reflects the ceiling of the baptistery and displays numerous stars of the night sky. Similar to the aedicula of the synagogue and its metaphorical relationship to the Jerusalem Temple, the Christian baptismal font references the sky that opened above the Jordan River where John baptized Jesus (Matthew 3:13-17, Mark 1:9-11, Luke 3:21-22, John 1:32-34). Painted above the surface of the baptismal water and under the vault are images of Jesus bearing a ram on his shoulders within a field surrounded by rams and Adam and Eve drawing apples from the tree of knowledge while the serpent approaches their feet (Exodus 3). The juxtaposition of these two allegorical images on the baptismal font reveals the foundations of Christian theology -redemption from the fall of man (Exodus 3) is gained through baptism in Christ Jesus the savior (Matthew 3:11). ${ }^{75}$

\subsubsection{Representation of Allegorical Space}

The remaining three walls of the Baptistery are divided into upper and lower registers. Beginning on the east wall opposite the baptismal font on the lower portion of the wall and ending on the north wall several images illustrate the discovery of Jesus' empty tomb (Luke 24:1-3). Five

${ }^{75}$ Ann Perkins. The Ant of Dura-Europos. (London: Oxford University Press, 1973) p. 53. 
women are represented beside a set of half opened doors. Again, on the north wall, the five women (only four were preserved) are shown adjacent to a large white sarcophagus. ${ }^{76}$ With bowls of spice in hand, the women illuminate the bodiless tomb with their torches. Their faces remain veiled as they realize the body of Christ has risen (Luke 24:4-8). Above the sarcophagus the upper register displays Jesus healing the paralytic (Matthew 9:1-8, Mark 2:1-12) and Jesus walking out to his disciples' boat on the surface of the water (Mark 6:45-50) (Fig. 20). Along side the doorway on the south wall, a Samaritan woman is shown at a well (John 4:7-14) on the lower register while the battle of David and Goliath (1 Samuel 17:20-50) is painted on the upper register.

In addition to the painted images of the Dura-Europos House Church, a fragment of parchment was discovered among the debris. Kraeling identified it as a portion of the Diatessaron, a harmony of the four gospels, created by Tatian at the end of the second century. ${ }^{77}$ According to Hopkins, the parchment along with the baptistery illustrations reveals that all four gospels were known in Dura. Hopkins suggests that the narratives painted in the baptistery make specific reference to each one of the four gospels. The five women, thought to be Mary Magdalene, Mary mother of James, Joanna and others who arrive at Jesus' tomb belong to the gospel of Luke (Luke 24:1-8). While the gospel of Matthew notes Jesus as the descendent David (Matthew 1:1-16), the gospel of John is the source of the well and the Samaritan woman (John 4:7-14). And finally the gospel of Mark is referenced for the miracle of Jesus healing the paralytic (Mark 2:1-12). Despite the dissemination of other writings (Acts of Thomas and Philip) 78 through the Roman world during the inception of Christianity, the relationship Hopkins draws between the four gospels and the

\footnotetext{
${ }^{76}$ Ann Perkins. The Art of Dura-Europos. (London: Oxford University Press, 1973) p. 53.

$\pi$ Clark Hopkins. The Discovery of Dura-Europos. (New Haven: Yale University Press, 1979) p. 108.

$78 \mathrm{lbid}$, p. 109
} 


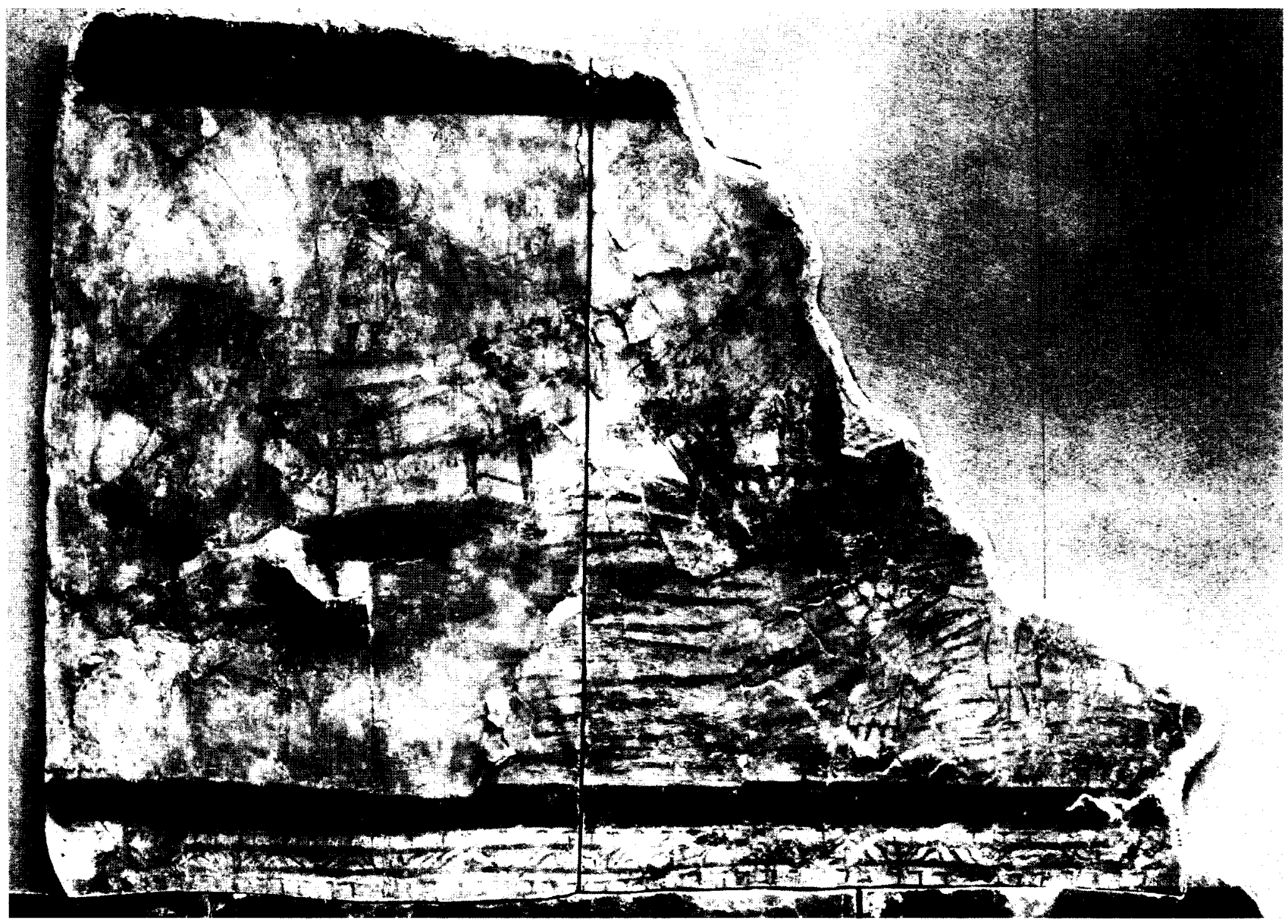


imagery of Dura-Europos baptistery suggests that allegorical space was created to place the four gospels as the four corners of the Christian theology.

The allegorical space of the Dura-Europos House Church baptistery reconciles Jewish theology with the new Christian covenant (Fig. 21). The imagery of the baptistery in relation to the font reveals the fundamental concept of Christianity. The sin of humanity is expressed in the images of Adam and Eve and the Samaritan woman. Forgiveness is attained through baptism in the redeeming grace of the messiah, Jesus the descendent of King David and crucified and resurrected son of God.

\section{$4.4 \mathrm{Ka} \mathrm{ba}$}

The Ka'ba has remained central to Islamic worship since 630 C.E. (Fig. 22). The Ka'ba has been rebuilt and reformed throughout Islamic tradition but has remained a testament to the Islamic faith from its earliest days. However, the history of the Ka'ba extends well beyond the inception of Islam (622 C.E.) to Adam and the creation of the world.

According to Islamic tradition, Adam laid the original foundations of the Ka'ba. Having been sent down to earth from heaven Adam questioned God asking why he could no longer hear the chant of the angels. The Lord answered it was because of his sin and commanded him to build a house and surround it as the angels around the Lords throne while praising God. ${ }^{79}$ After traversing land and sea Adam arrived in Makkah where he and the angel Jibril built the house of God. ${ }^{80}$ Following the death of Adam the canopy of the Lords House was drawn to heaven and the

\footnotetext{
${ }^{79}$ Najib Gedal. Geometric Analysis of the Ka'ba (Al-Sharifa). (Riyadh: King Saud University, 1999) p. 29.

80 Ibid, p. 30.
} 

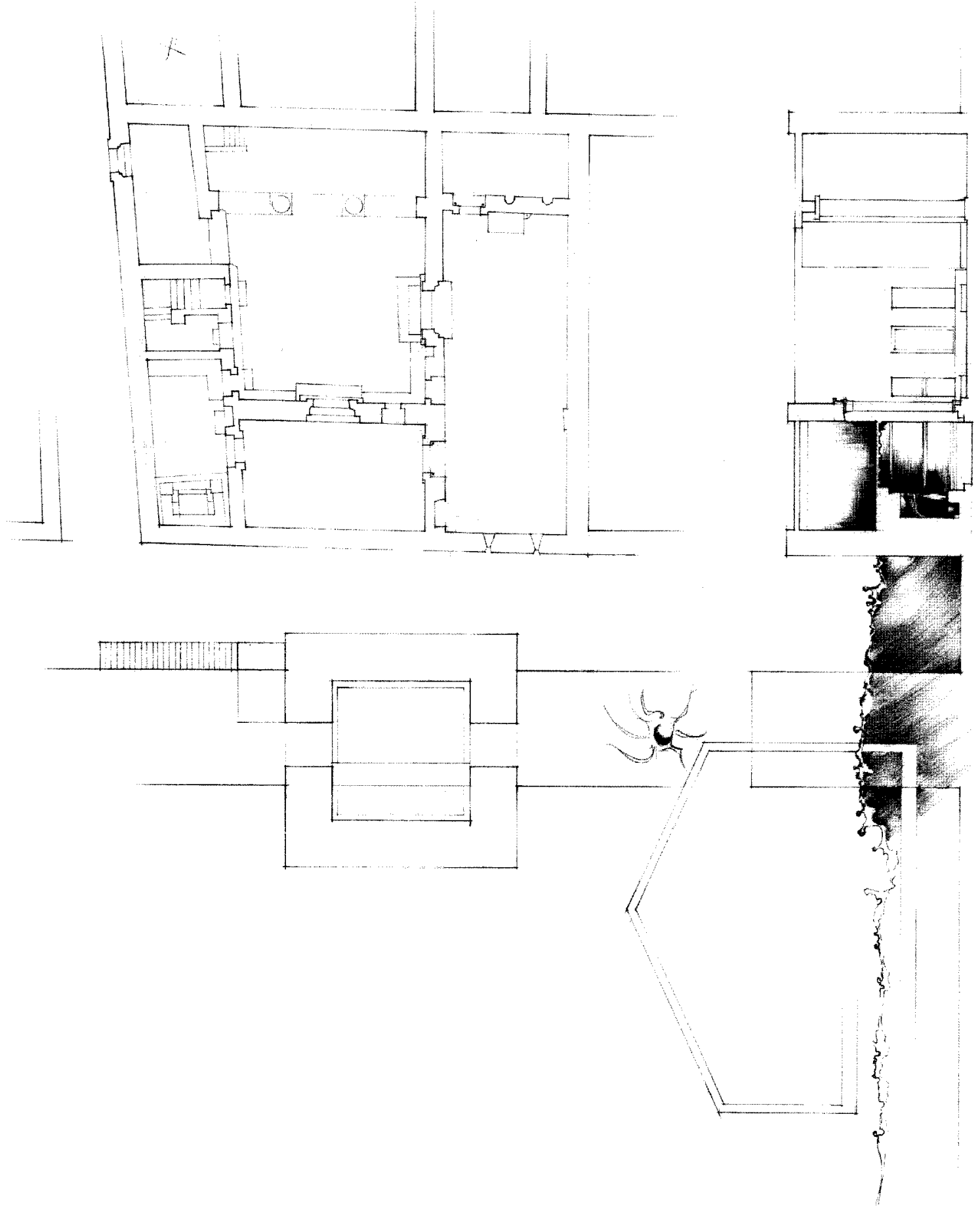

Reproduced with permission of the copyright owner. Further reproduction prohibited without permission. 


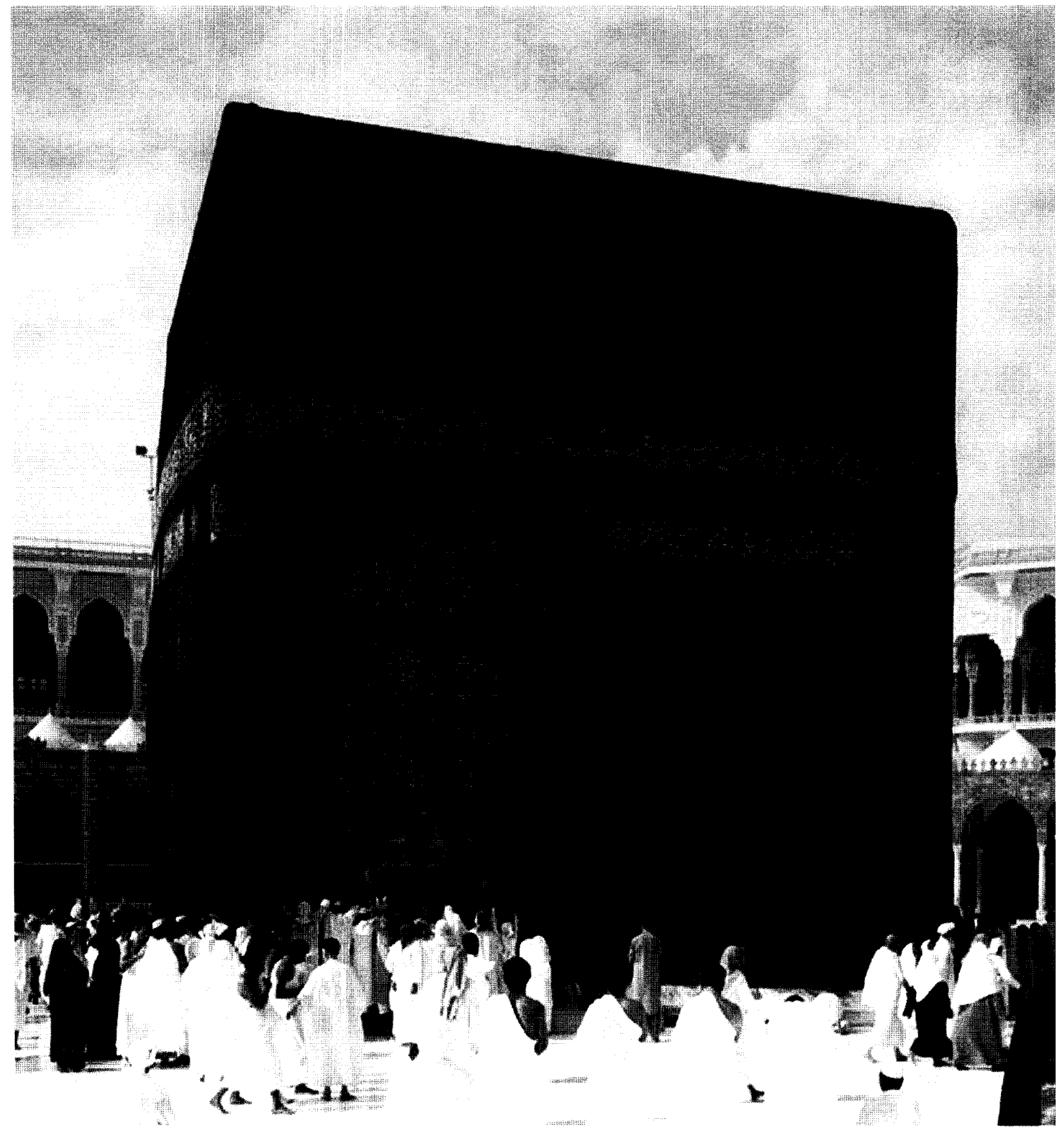

Fig. 22

Reproduced with permission of the copyright owner. Further reproduction prohibited without permission. 
sons of Adam rebuilt the House with stone and clay. ${ }^{81}$ The house of God was again erased by the flood during the time of Noah, ${ }^{82}$ until the site was revealed to Abraham (Sura 22:26) who along with his son Ishmael unearthed the foundations from the sand and constructed the Ka'ba upon them (Sura 2:127). The angel Jibril delivered an exceptional Black Stone to Abraham who embedded it in the corner of the walls that he and Ishmael raised. ${ }^{83}$

Besieged by numerous fires and floods the Ka'ba had fallen into ruin and it was decided by the tribe of Quraysh to rebuild the Ka'ba in 600 C.E. Baqum, a Christian carpenter on his way to Abyssinia was shipwrecked off the seaport of Makkah, his ship held the building materials that he and the Quraysh used to rebuilt the Ka'ba. The structure was rebuilt inside the original foundations, three straight walls were built and one curved wall which marked the edge of the structure Abraham created. ${ }^{84}$ The Ka'ba again fell a victim, this time to Ibn Numayr and his army of catapults. The catapults weakened its walls and tore the kiswa that covered the stone house. When the battle seized and Ibn Numayr was diverted to Damascus, Al-Zubayr demolished what remained of the Ka'ba in 640 C.E. and constructed it as per the foundations of Abraham, increasing the height to 27 cubits. Makkah was taken under the control of the Umayyads in 692 C.E. and Al-Hajjai wrote to Caliph Abd al-Malik IbnMarwan requesting permission to restore the Ka'ba. He was ordered to stone the doorway and destroy the section Al-Zubayr added to the Hijr. ${ }^{85}$ The renovations attributed to Al-Zubayr reflect the contemporary form of the Ka'ba, suggesting that the structure has remained relatively unchanged.

\footnotetext{
81 Najib Gedal. Geometric Analysis of the Ka'ba (Al-Sharifa). (Riyadh: King Saud University, 1999) p. 29.

82 lbid.

83 Ibid, p. 31.

84 Ibid, p. 32.

85 lbid, p. 34.
} 
During the Jahiliyyah (pre-Islamic period) the Ka'ba housed numerous tribal gods. After the battle of Badr (Sura 8:17, 3:123) the Quraysh attacked the Prophet Muhammad and the Muslims of Madinah (the city of the Prophet). The Quraysh were defeated and the Makkans sought a truce with the Prophet. The arrival of the Prophet Muhammad at Makkah in 630 C.E. marked the end of the Makkan pantheon. The city was converted to Islam and the gods residing in the Ka'ba were destroyed. After settling in Madinah in 622 C.E. a mosque was built adjacent to Muhammad's house and the Muslims prayed in the direction of the Qiblah, a niche set within the mosque wall aligning with Jerusalem. Not long after this tradition was established Muhammad prayed to Allah who commanded the Qiblah be reoriented toward the Inviolable sanctuary, the Ka'ba at Makkah (Sura 2:143-144). This tradition of oriented prayer is shared by the Synagogues of Rabbinic Judaism. The Torah niche and the Islamic Qiblah are both devices to orient worship as well as architectural metaphors. The Torah niche and its metaphorical relation to the Jerusalem Temple was discussed previously, the Qiblah metaphorically represents the unity of Islamic faith and prayer which is embodied in the Ka'ba.

\subsubsection{Allegorical space of the Ka'ba}

Following the reorientation of the Qiblah the Ka'ba was emptied of its former tribal gods and became symbolic for the invisible Abrahamic God and the unity of the Muslim faith. The Ka'ba was adorned with the kiswa, a fabric covering with embroidered Qur'anic revelation. The imagery of the kiswa and the architectural space of the Ka'ba manifest the Allegorical space of the Ka'ba which shapes the movement of worship (Sura 2:125) and reveals Islamic theology. The presences of the void in Islamic imagery and architecture draw the worshiper into the space of Abrahamic theology while residing in the material space of earth. 


\subsubsection{Representation of Allegorical Space}

The intersecting horizontal and vertical characters of Kufic calligraphy embroidered upon the kiswa, circle the Ka'ba in similar fashion to a pilgrim of the Hajj (Fig. 23). The Ka'ba is understood as a metaphorical column rising to heaven, around which Islamic worshipers orbit. The allegorical form of Islamic calligraphy traces the rotation of worship and unfolds the revelation of Allah. The shape of Kufic calligraphy surrounding the Ka'ba reveals one of the five pillars of Islam. ${ }^{86}$ Although the specific excerpt of Qur'anic revelation that adorns the kiswa changes with each year, the allegorical reading of the calligraphy remains the same.

The Dura-Europos synagogue and house church, and the Ka'ba are made of an interwoven composition of material form and Abrahamic imagery, or allegorical space. They are among the earliest known architectural manifestations of the faiths, suggesting the relationship between architecture and imagery is common among the three faiths and its history extends to the earliest developments of their theological representation.

86 Willard Oxtoby. World Religions. (Don Mills: Oxford University Press, 2002) p. 360. 


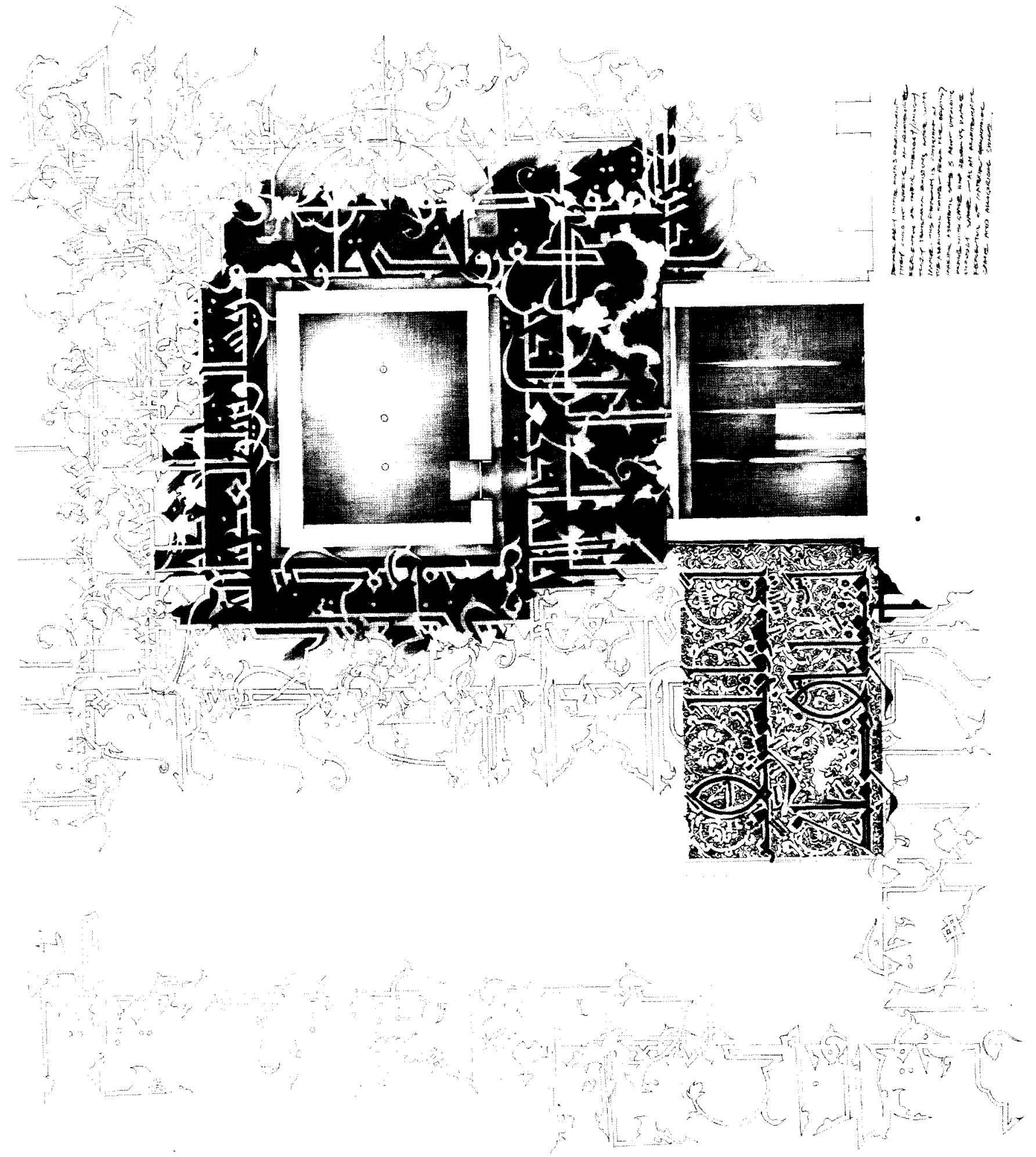




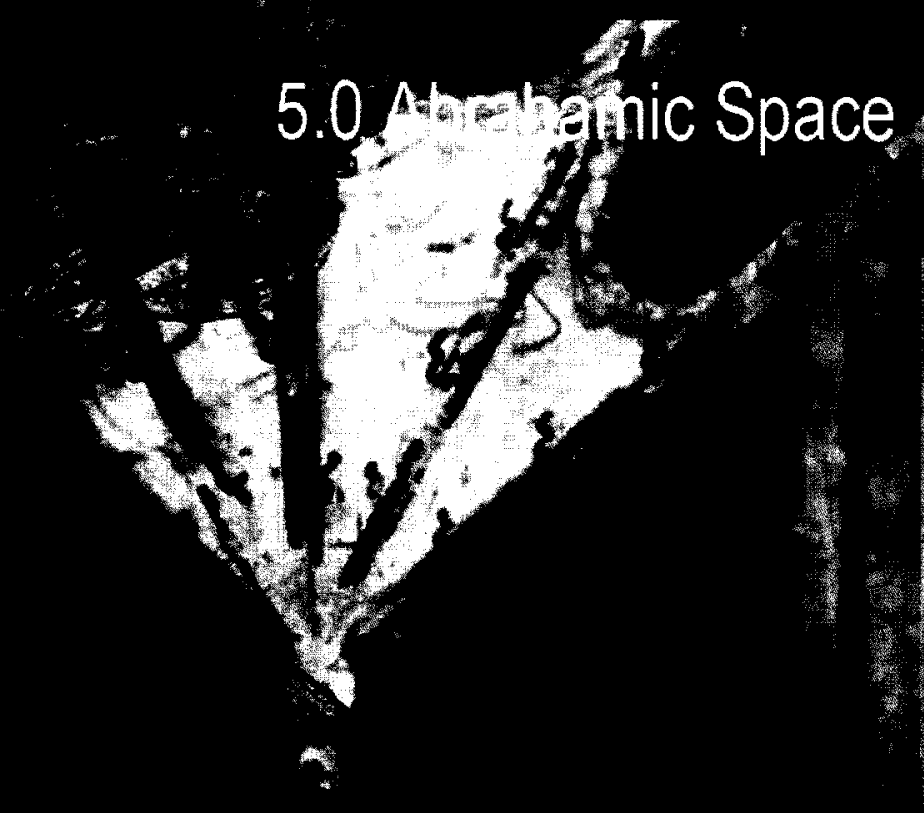




\subsection{Abrahamic Space:}

\subsection{Abrahamic Theological Space}

The spatial context in which the Abrahamic theology finds its origins is described in $A$ History of God. According to Karen Armstrong, both early Semitic and classical religion understood human and divine to be shaped from the same substance and to coexist in the earthly realm. While discussing the context surrounding the inception of Abrahamic thought, Armstrong sees an interesting relationship between the space the faithful dwelled within and the structure of their thought. Armstrong describes a fragile world overshadowed by mortality. Hoping to some degree to share the capacity of their gods, the people imitated their actions and built cities and temples which mirrored that of the divine. Their holistic view saw no separation between the world of the divine and that of the humans. Armstrong suggests: "The sacred world of the gods - as recounted in myth - was not just an ideal towards which men and woman should aspire but was the prototype of human existence; it was the original pattern or the archetype on which our life here below had been modeled." 87 Developing from within this paradigm Hebrew ideology was founded upon a spatial logic that differed from their pagan neighbors. Abrahamic ideology emerged in opposition to this holistic world, by creating a separation between human and the divine. Yahweh, the Abrahamic God, is believed to inhabit the heavenly realm and demonstrates his existence through revelation recorded in the Torah, New Testament, and Qur'an.

Abrahamic Architecture defines a space in which a reality can be manifest. The Hebrews separation of physical and ontological space opened the way for divine revelation. "Revelation" language as Frye has described it is a generative form of language requiring interpretation.

${ }^{87}$ Karen Armstrong. A History of God. (London: Alfred A. Knopf, Inc., 1999) p.12. 
Abrahamic faith seeks a truth that lay beyond the physical. Their architecture, in part, through the use of imagery, refers to space beyond itself and reveals the underlying spatial construct of their theology. This idea was discussed in the previous chapter in reference to the earliest architecture created by the individual faiths. But the creation of allegorical space by the three Abrahamic faiths is not limited to these early examples. During the middle ages, as the Christian and Islamic empires surrounding the Mediterranean Sea struggled to increase their territory, borders were blurred. Cities located within these shifting territories were culturally diverse, housing Diaspora Jews, Christians and Muslims. While the rule of theses cities remained tenuous, their inhabitants continued to build synagogues, churches, and mosques. The architectural overlaps occurring among theses abandoned, re-inhabited and collaboratively designed buildings reveals the unity of the Abrahamic faiths in the creation of allegorical architecture.

\subsection{Santa Maria la Blanca (Saint Mary the White) Synagogue/ Church and Transito (or Prince's) Synagogue/ Church}

The city of Toledo in contemporary Spain contains several works of Abrahamic architecture pieced together over time as the result of layered contributions from the various faiths. Among them are the Santa Maria la Blanca Synagogue/ Church and Transito Synagogue/ Church in the Jewish quarter (Fig. 24). The Santa Maria la Blanca (Saint Mary the White) Synagogue/ Church held Jewish worship for the two decades that followed its construction in 1203 C.E., it was later converted to a Christian church and renamed Santa Maria la Blanca. ${ }^{88}$ The synagogue was built by Muslim craftsmen who layered Jewish and Islamic architectural image traditions in the construction of the prayer hall. The building conformed to a slightly skewed rectangular site which was filled with five bays of varying heights aligning with Jerusalem. The bays were defined by a

88 Jesus Pelaez del Rosal. The Synagogue. (Cordoba: Ediciones el Almendro, 2003) p. 119. 
grid of octagonal columns crowned with ornately carved capitals holding oval arches adorned with numerous variations of Islamic patterns (Fig. 25). The capitals were shaped in conformance with the varied Islamic patterns that surround the prayer hall and give shape to the wooden doors of the synagogue (Fig. 26). The sculpted patterns are similar and in some cases the same as those found in numerous mosques, illustrating the Abrahamic notion of space through the representation of material and void. The Islamic patterns remained above the arches after the synagogue were painted white and inhabited by Christians.

A similar fate was also had by the Transito (or Prince's) Synagogue/ Church which was given form by Muslim craftsmen for Jewish worship in 1357 C.E. ${ }^{89}$ The synagogue is a rectangular in plan and two storeys in height with an overlooking gallery for women. An elaborately constructed ceiling shapes the heavens above heavy wood timbers that span the prayer hall and leave the space uninterrupted. The walls of the synagogue are sculpted with Islamic patterns and Torah scripture that rise to the veiled clerestory windows from which dappled light falls into the prayer hall (Fig. 27). Similar to the Qur'anic revelation circling the Ka'ba, Jewish revelation from the Torah books of Psalms, Chronicles, Kings and Exodus are inscribed in Hebrew characters surrounding the synagogue. Under the Torah inscriptions is Arabic calligraphy denoting messages of peace and prosperity to those of the Jewish faith. The Transito synagogue was adapted into a Christian church in 1494 C.E. ${ }^{90}$ The architecture of the synagogue remained unchanged, save for a niche added in the south wall.

89 Jesus Pelaez del Rosal. The Synagogue. (Cordoba: Ediciones el Almendro, 2003) p. 121.

90 lbid. 


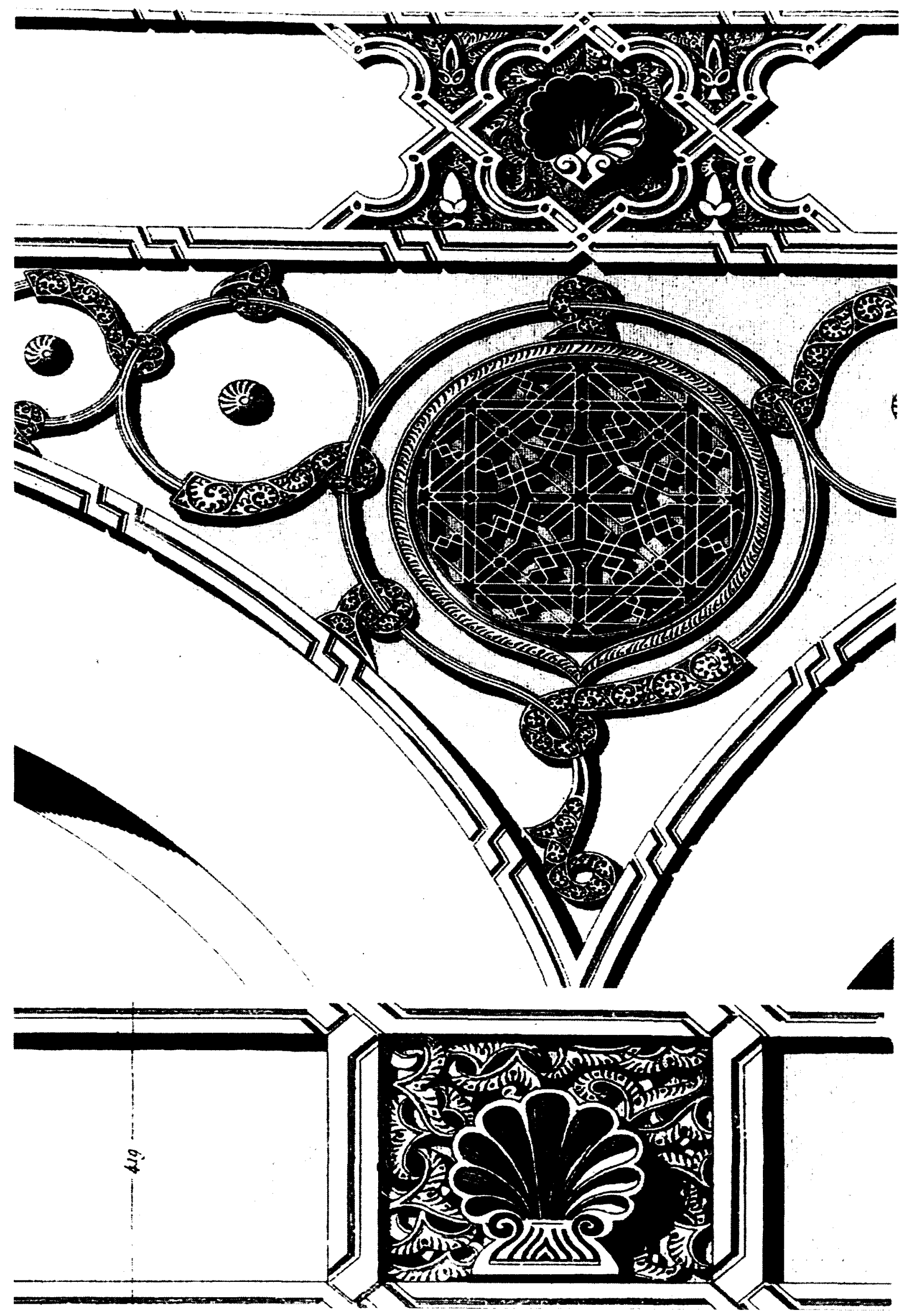

Fig. 25 


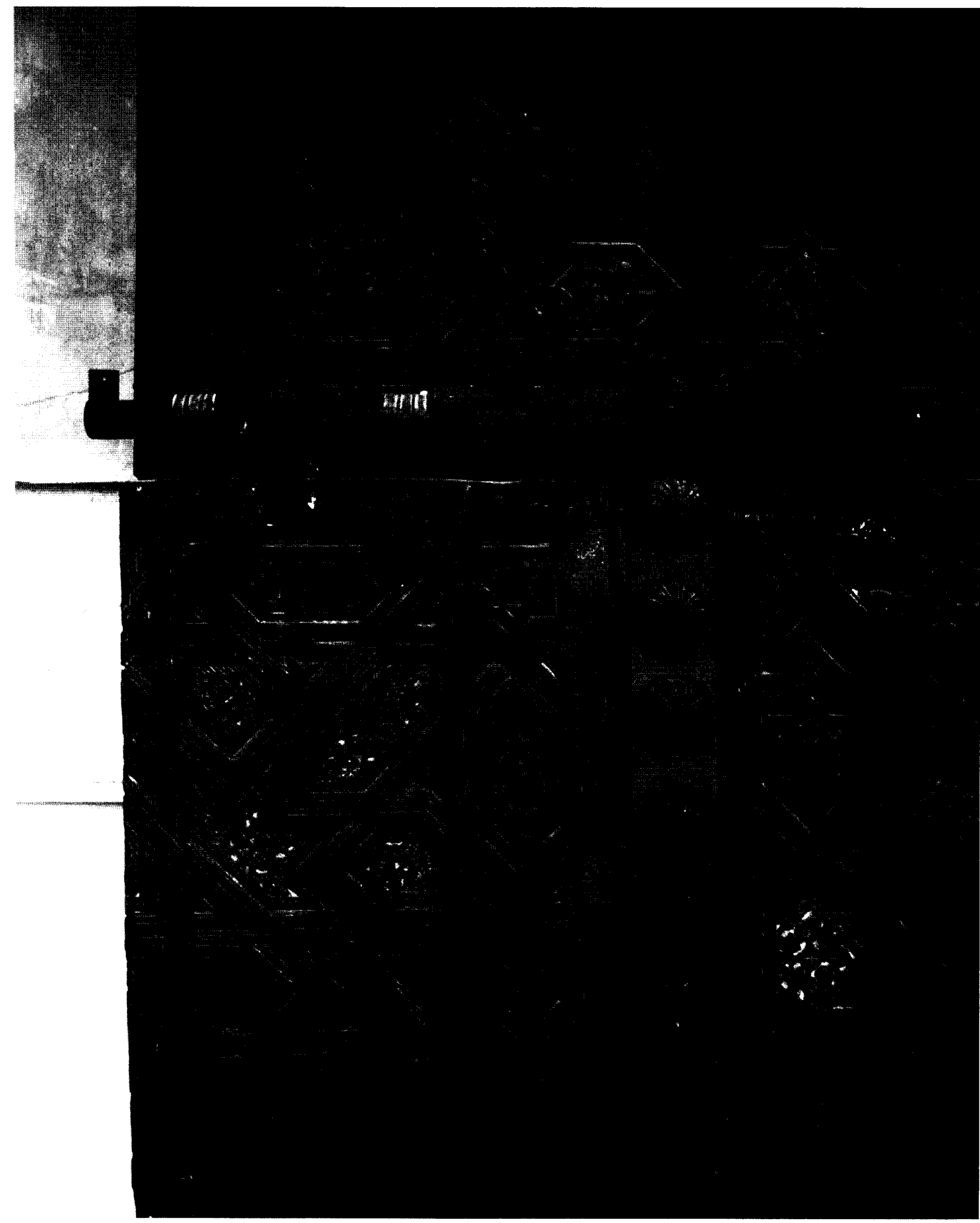




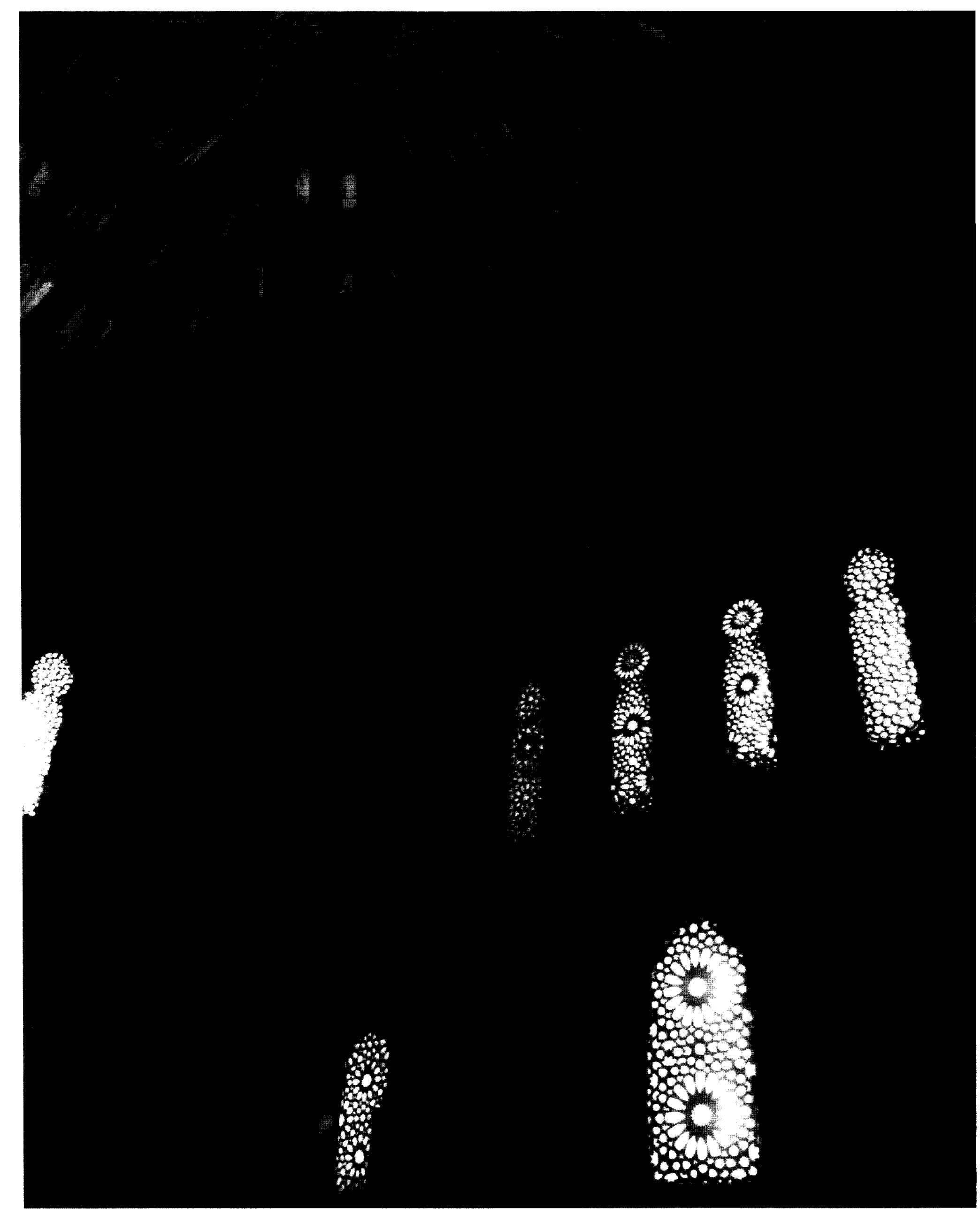


Similar to the Dura-Europos synagogue, the Transito (or Prince's) Synagogue/ Church and to a lesser degree the Santa Maria la Blanca (Saint Mary the White) Synagogue/ Church the walls of the buildings are adorned with allegorical imagery. The imagery reflects the Islamic illustrations of Sura 1 or "The Opening" discussed previously. Interwoven Islamic geometric and floral patterns surround Torah revelation that wraps the prayer hall like the kiswa covering the Ka'ba (Fig. 28). The allegorical imagery reveals the shared spatial manifestation, consisting of material space and void or imagined space of Judaism, Christianity and Islam.

\subsection{El Cristo de la Luz (Christ of the light) Mosque/ Church}

Not far from the Santa Maria la Blanca and the Transito, also set within the perimeter wall surrounding Toledo is the Cristo de la Luz (Christ of the light) Mosque/ Church. Foundation inscriptions found on the structure originally designed as a mosque date it at 999 C.E. The proportions of the nine square grid mosque mimic the Ka'ba to which it is directed. However, unlike the opaque and impenetrable surfaces of the Ka'ba the mosque is transparent, open and accessible from the four cardinal points. Four slender columns framed by heaver perimeter columns order the interior space of the mosque and draw the inhabitants' perception toward nine ornately ribbed domes which give form to the heavens. Adopting the theory K.A.C Creswell developed on nine square grid domed structures found in Egypt, Geoffrey R.D. King suggests that Cristo de la Luz was designed as a funerary structure. ${ }^{91}$ King points out that the decoration of the mosque is a reflection of the Spanish Umayyad tradition but it also fits into a wider field of funerary structures built throughout the Islamic world. Creswell's theory that the domed structure is tied to funerary architecture suggests that the dome of the mosque is a representation of the hereafter

\footnotetext{
${ }^{91}$ Geoffrey R.D. King. The Mosque of Bab al-Mardum and the Islamic building tradition. (Toledo: Actas del Congreso Internacional, 1999) p. 270.
} 


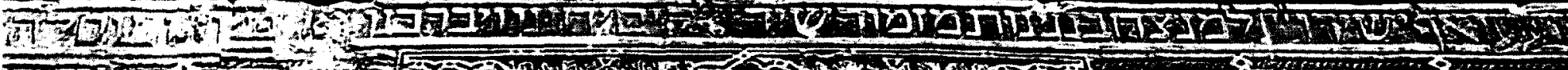

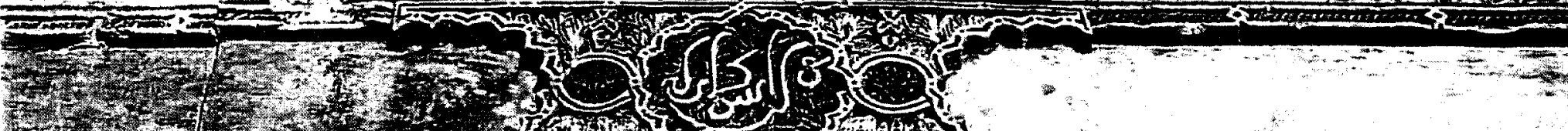

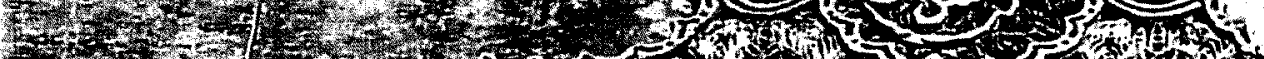

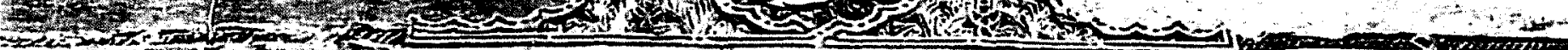

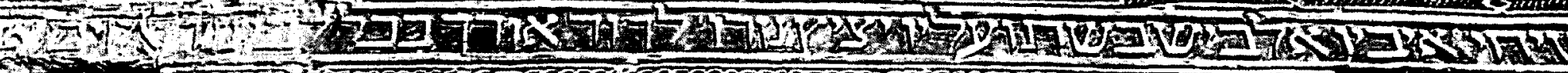

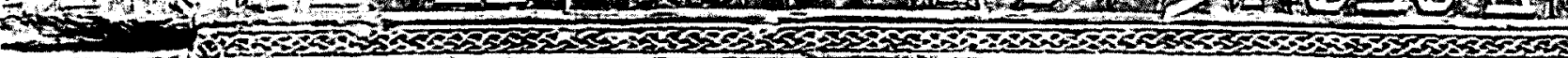

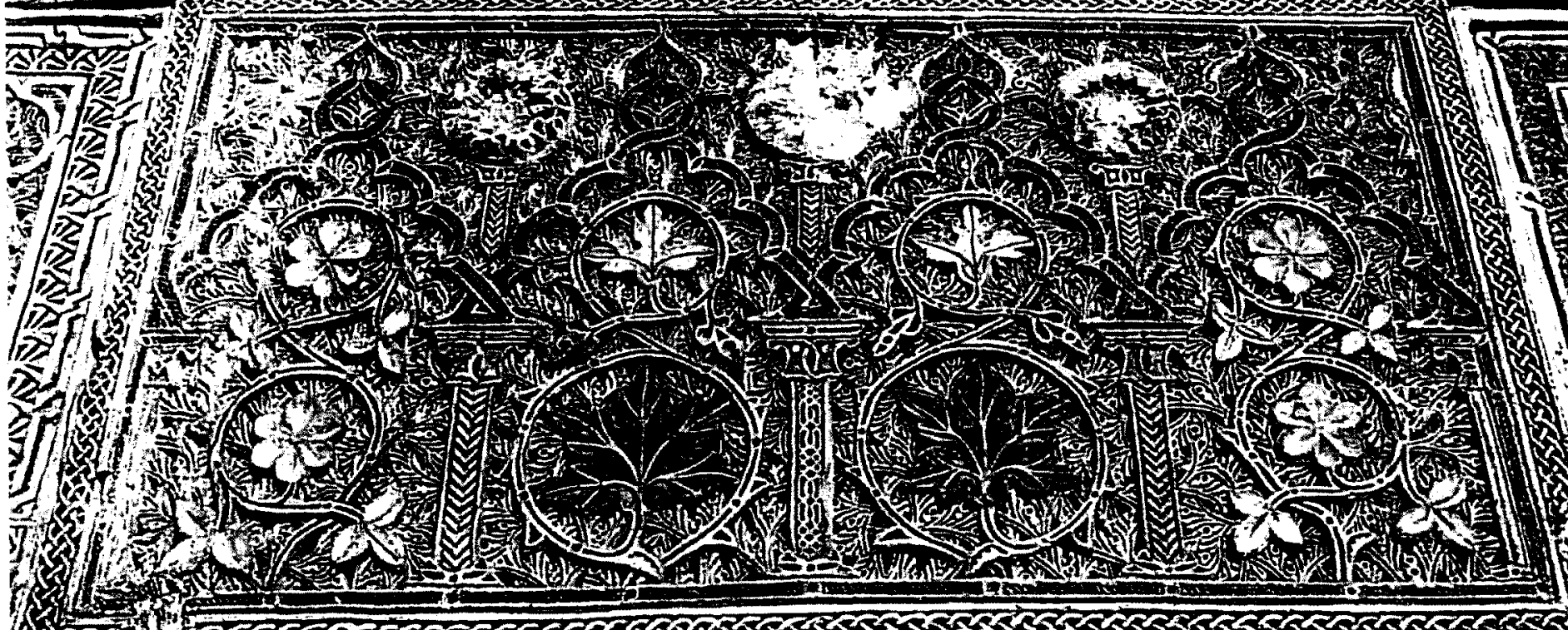

6)

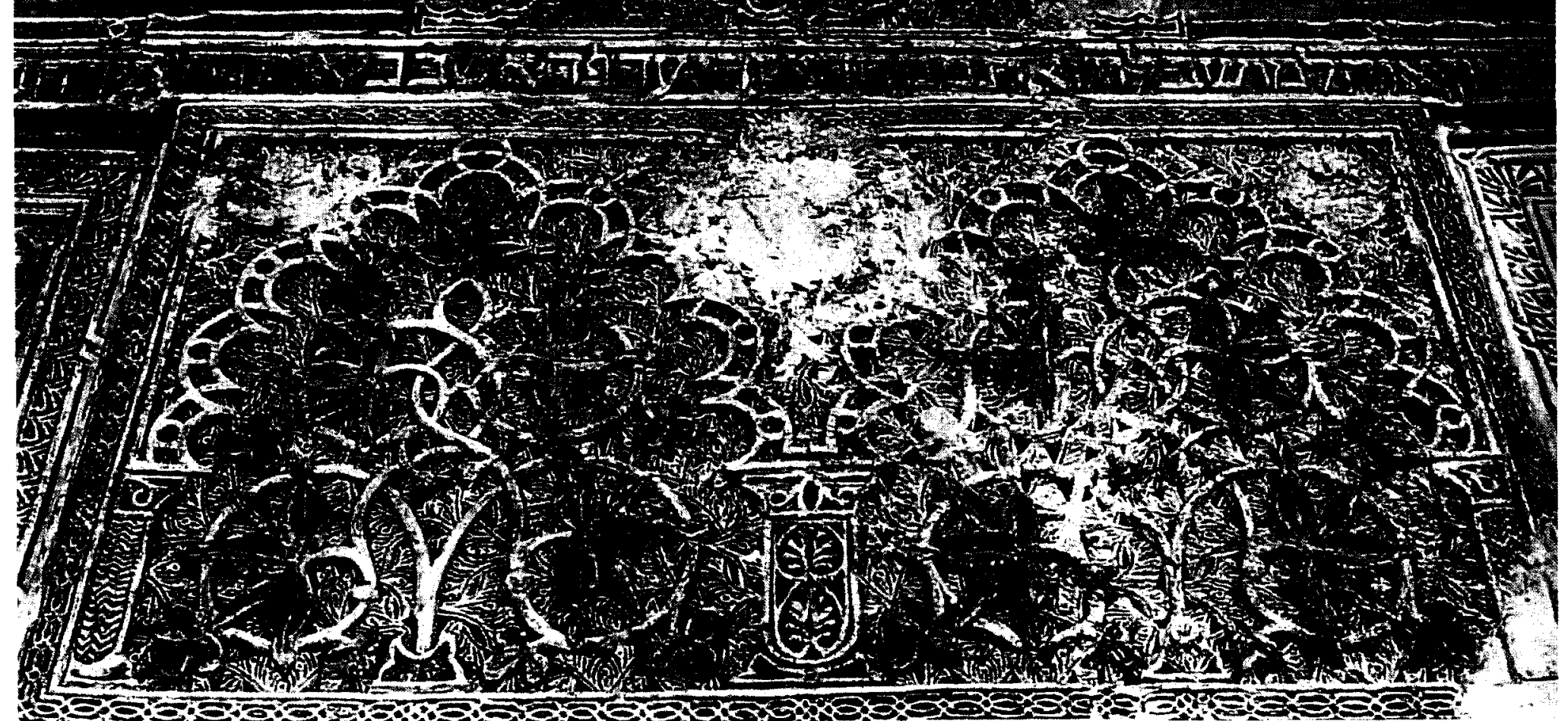


(Fig. 29). The nine ribbed domes that give shape to El Cristo de la Luz are each unique in form, they mirror those found in the mosque at Cordoba (Fig. 30, 31) and are presumably architectural interpretations of Islamic patterns. The theological and spatial dimensions of Islamic imagery discussed earlier appear to be the nucleus from which the Cristo de la Luz domes were derived as architectural translations of Islamic imagery.

El Cristo de la Luz fell under Christian control in 1085 C.E. and acquired the name 'Christ of the light.' Following its conversion in 1187 C.E. a single bay covered with a groin vault and an apse extended the church toward the east. The adapted plan of the mosque/church shares a symmetrical morphology as that of the Ka'ba, which prior to its contemporary square plan also contained an apse that was later removed (Fig. 23, 32, 33). As discussed previously the construction of the 600 C.E. Ka'ba was built in collaboration with Baqum, a shipwrecked Christian carpenter. Islamic geometric patters transformed into stone vaults shape the heavens above the mosque/ church and recall the numerous painted stars rendering the heavens and the ceiling of the Dura-Europos house church baptistery. The allegorical space of the Cristo de la Luz (Christ of the light) mosque/ church draws back the clouds to provide a view of the heavens for both Christians and Muslims alike.

\subsection{Ayasofya (Saint Sophia) Church/ Mosque}

Opposite Spain the border between the Christian world residing north of the Mediterranean Sea and the Islamic empire to the south was marked by Constantinople/ Istanbul (Fig. 34, 35). The city of Constantinople was built to house Emperor Constantine and preside over the Roman Empire. Following the 'Edict of Milan' in 313 C.E., a document that prohibited the persecution of Christians, their church buildings begin to reshape the public edifice and religious landscape of the 


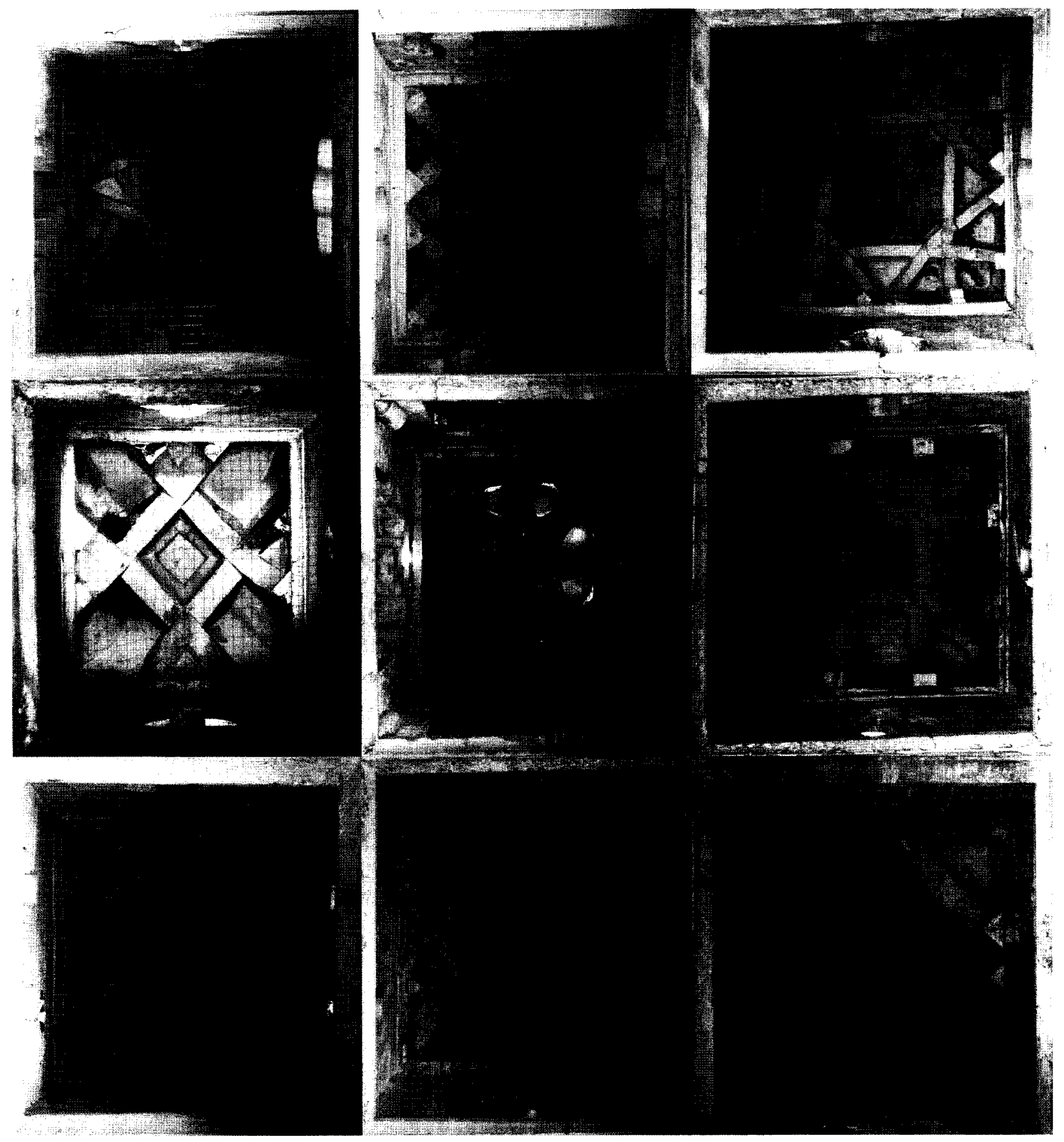




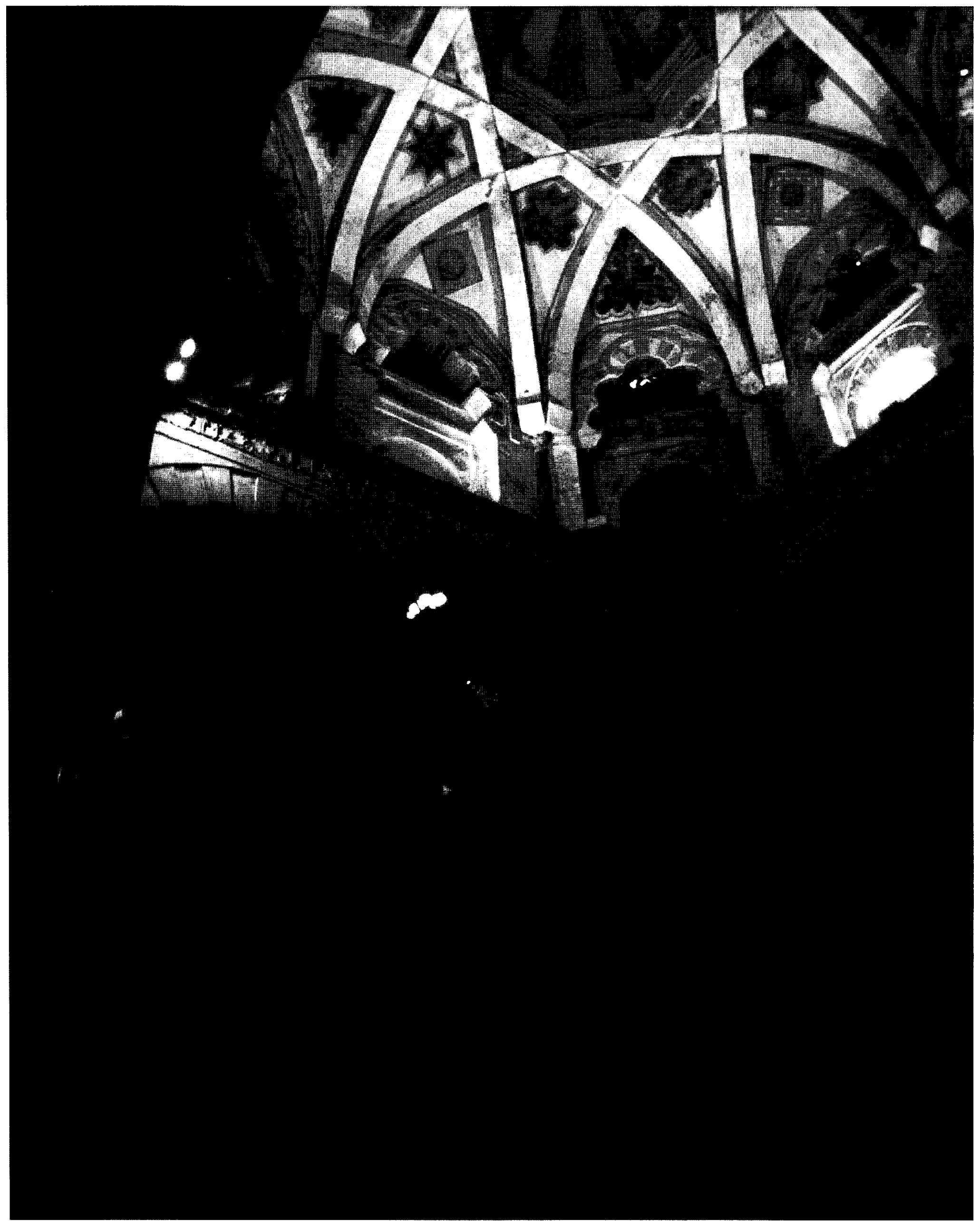



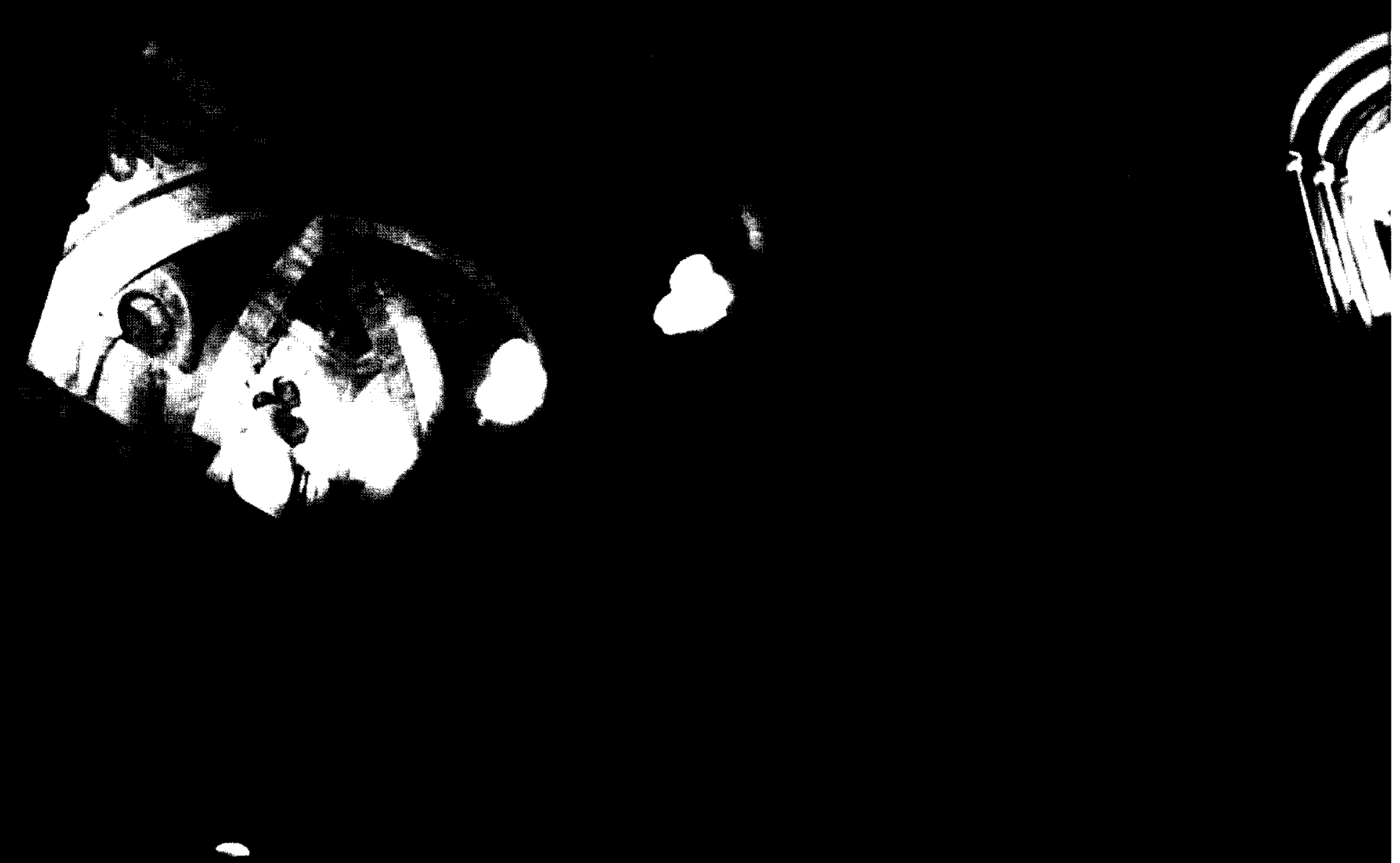

$\rightarrow$ 


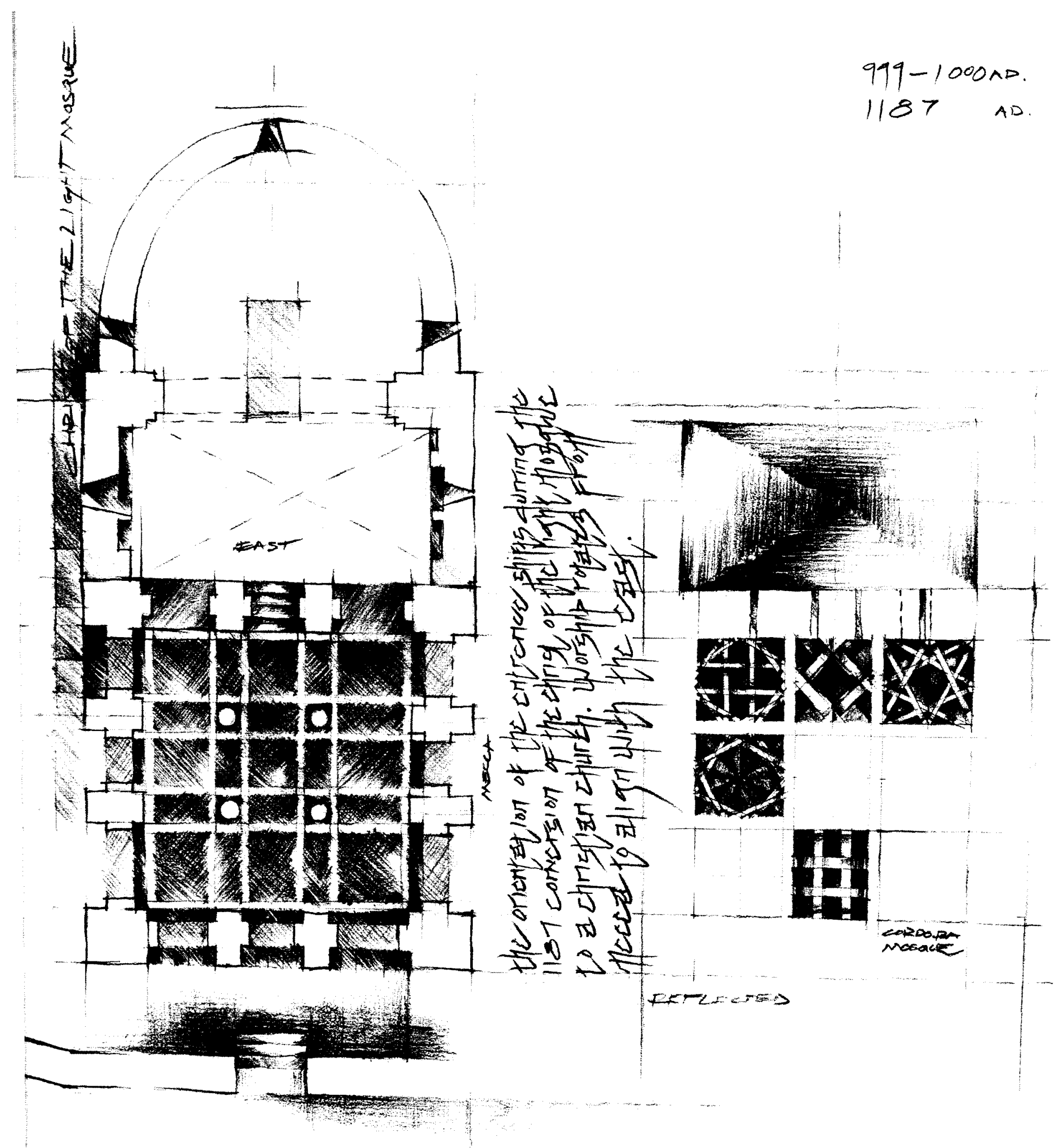

Fig. 32 


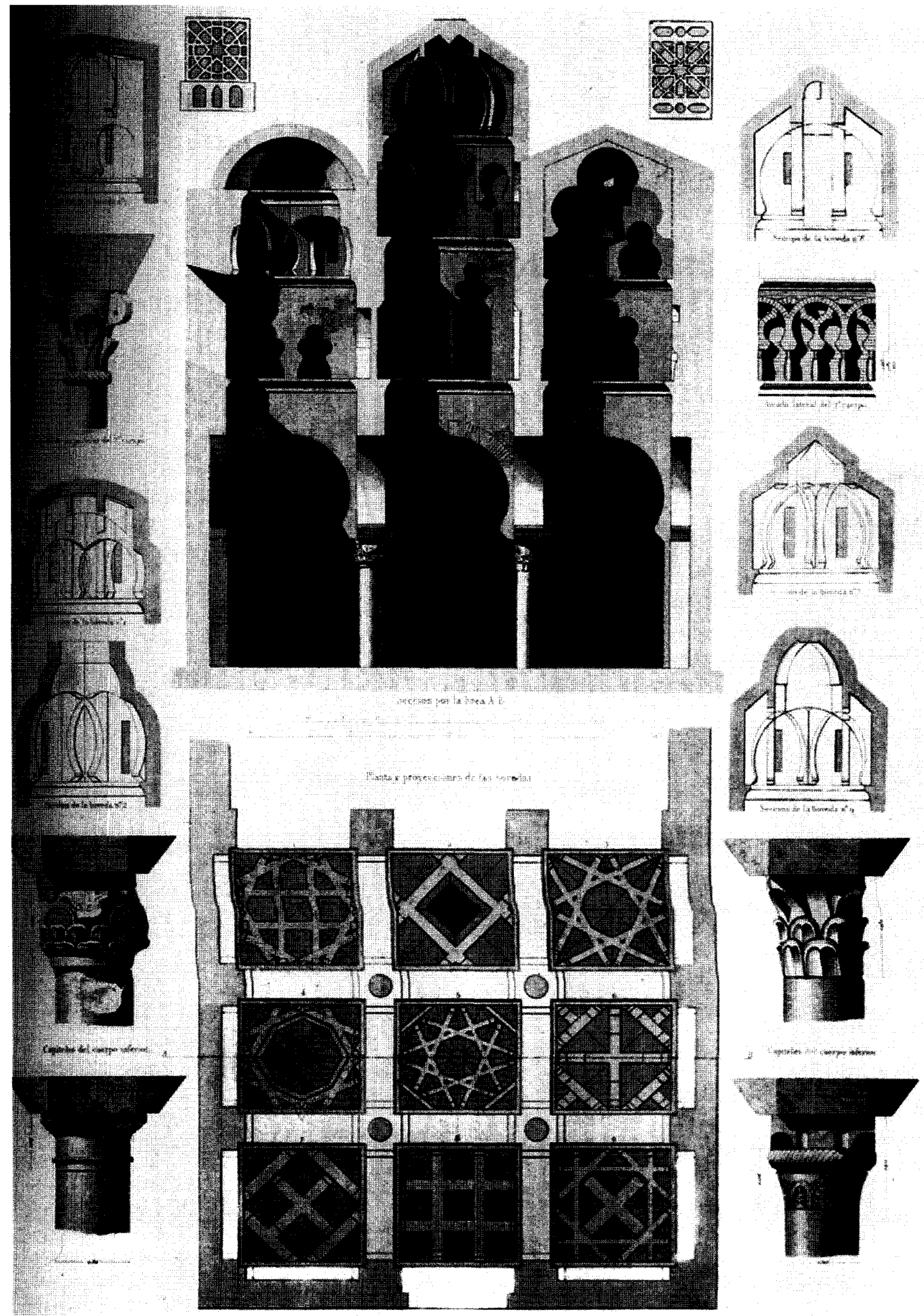

Fig. 33 


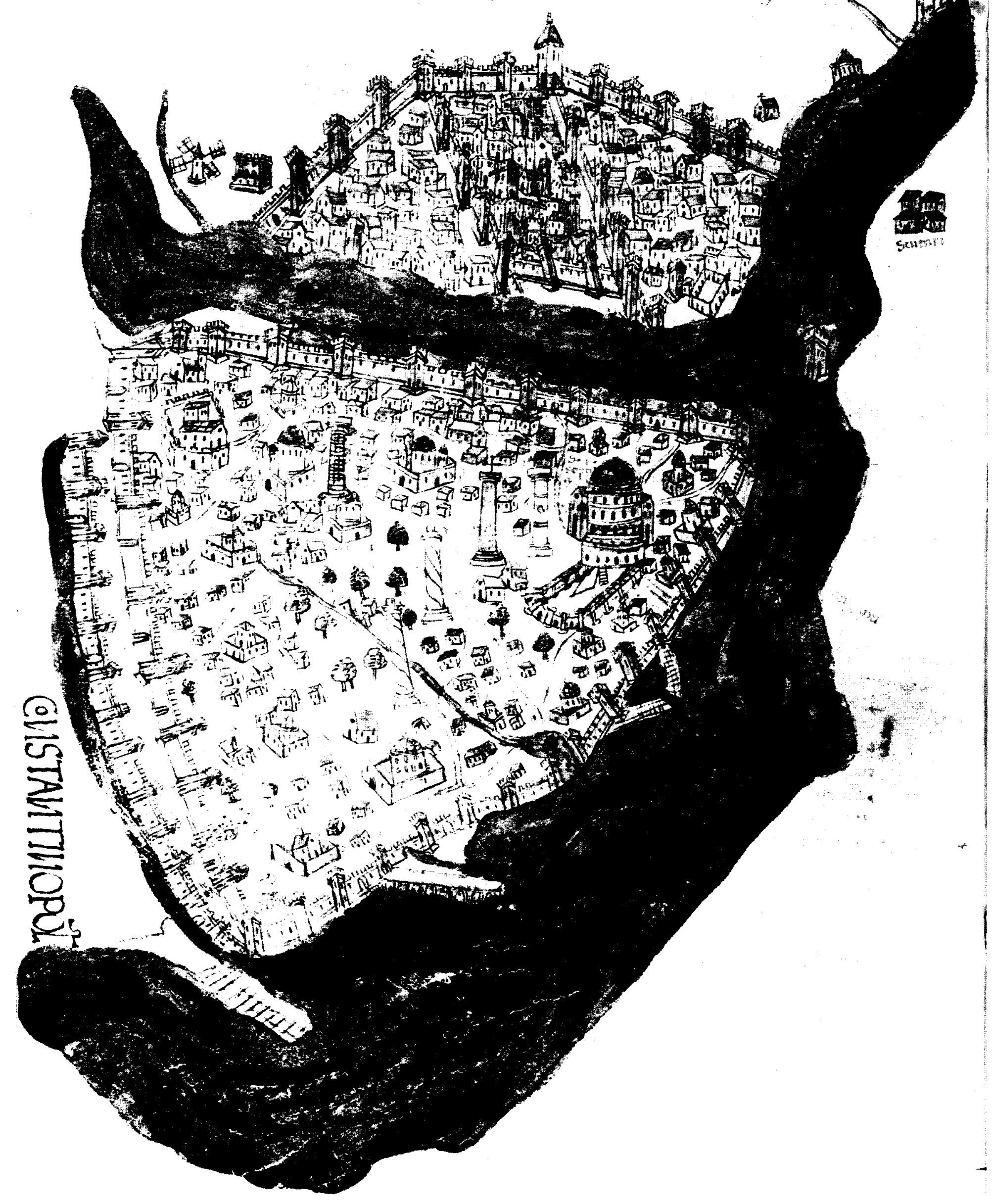

Fig. 34 


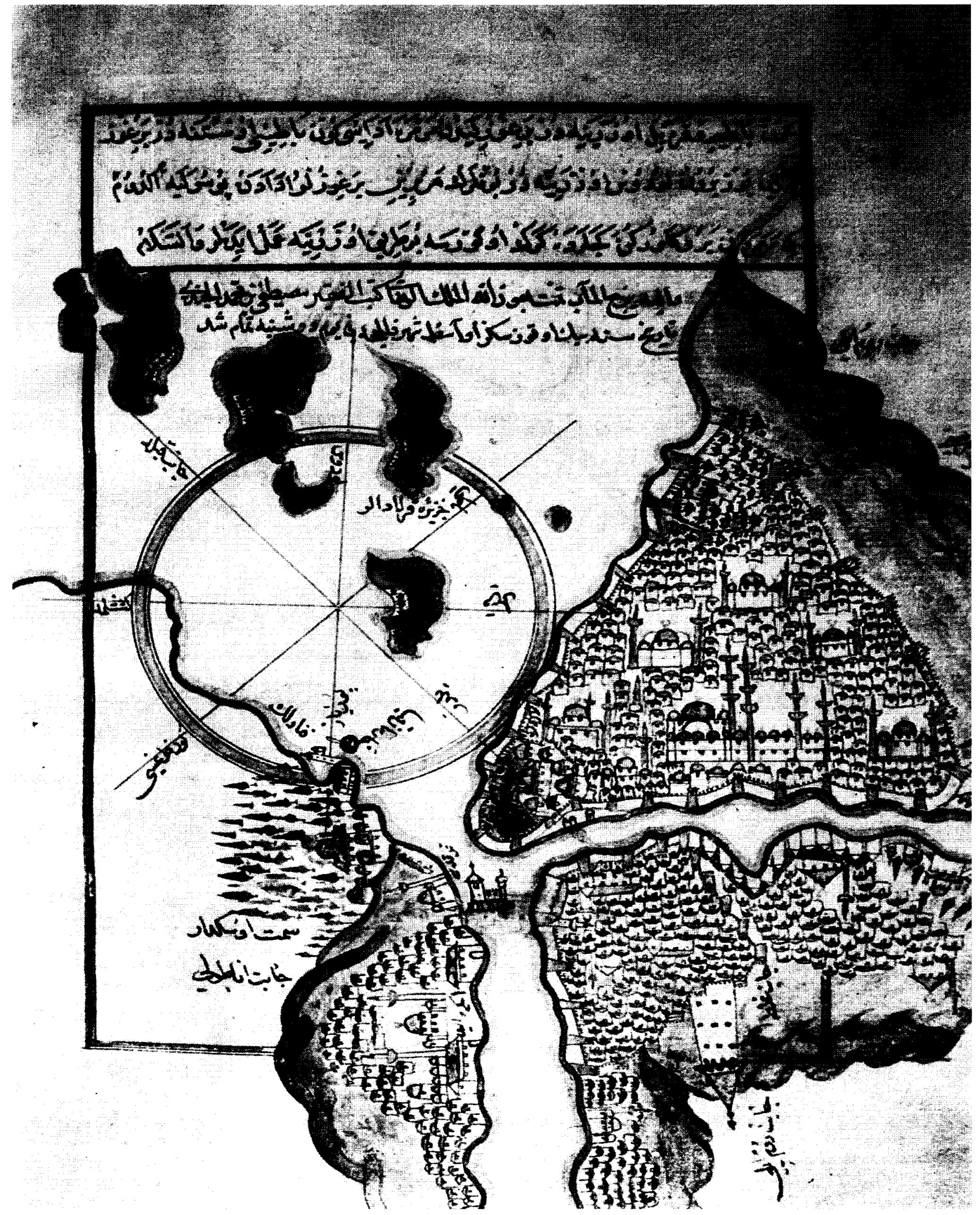

Fig. 35 
empire. Constantinople was the site of numerous Christian churches most significant among them was Saint Sophia (Fig. 36, 37).

Anthemius of Tralles and Isidorus of Miletus were responsible for the design of Saint Sophia which began construction in 537 C.E. ${ }^{92}$ The Christian church was modified into a mosque and renamed Ayasofya in 1453 C.E. following the Ottoman conquest of Constantinople. Hidden within the shadows of the glorious church/ mosque, formerly the grandest in both Christian and Islamic empires, is allegorical imagery revealing a space beyond the material existence of the architecture (Fig. 38).

Four massive columns occupy the corners of a square plan that is set within a complex set of geometries that order the church/ mosque (Fig. 39). Stone columns rise from the floor a great distance before they transform into pendentives and are later reunited as a circular dome 55.6 meters above the floor. Residing on the reverse side of the four columns that embrace the dome are the remaining fragments of frescoed images. The allegorical imagery creates a dialogue between the content of the image and the space of the architecture. The content of the column imagery is not figurative, but spatial (Fig. 40). The imagery projects an illusionary or imagined space within the depth of the stone column. The space exists as a visual and imaginary experience but remains uninhabitable in the physical sense. The column represents the underlying spatial or architectural structure of Abrahamic theology. It reveals the parallel perception that is required of the believer by permitting the observer to occupy two types of space simultaneously. The first space is shaped by stone. The second space is nascent and requires the worshiper to see

${ }^{92}$ Suleyman Kirimtayif. Converted Byzantine Churches in Istanbul. (Istanbul: Ege Yayinlari, 2001) p. 9. 


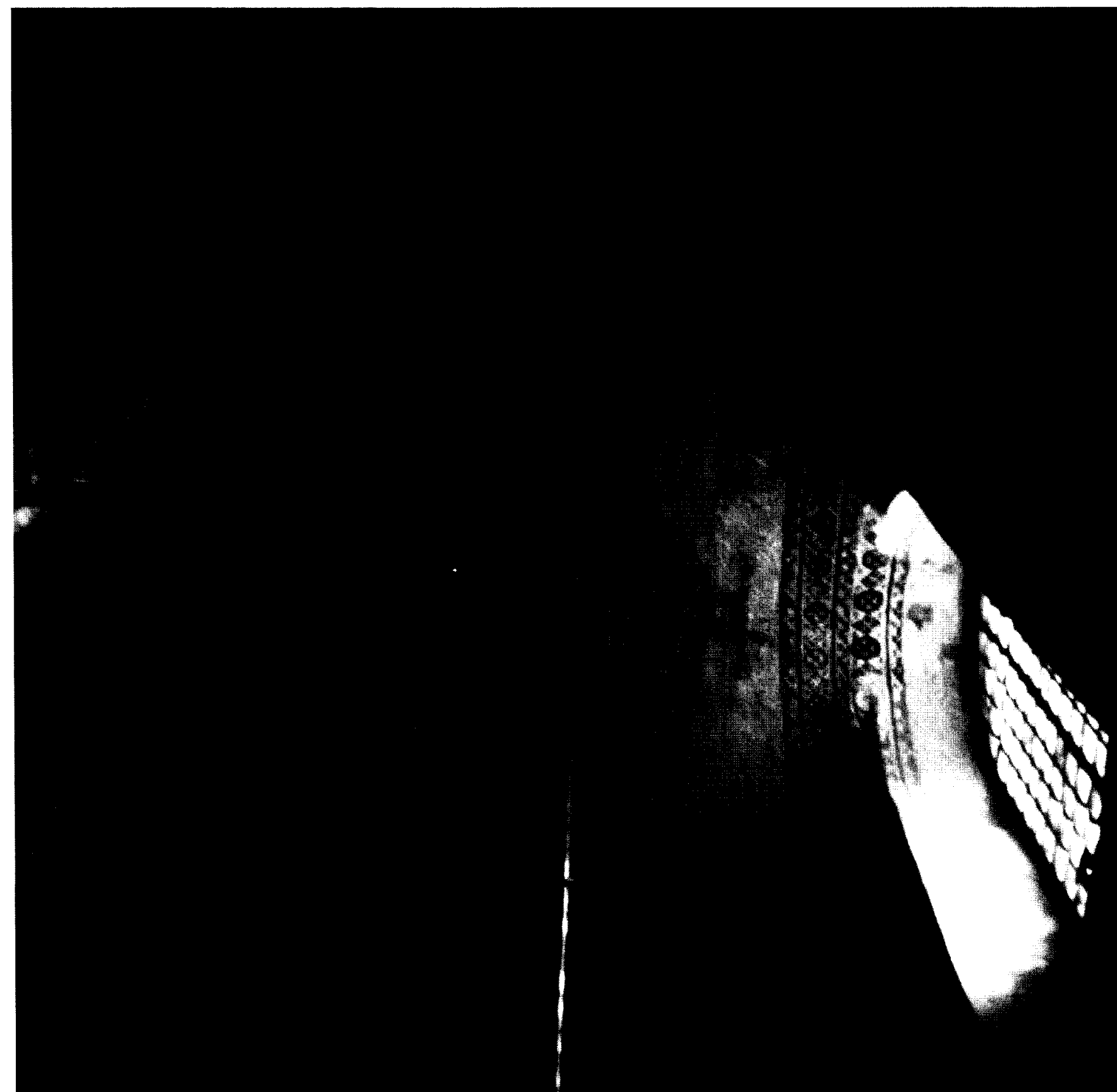



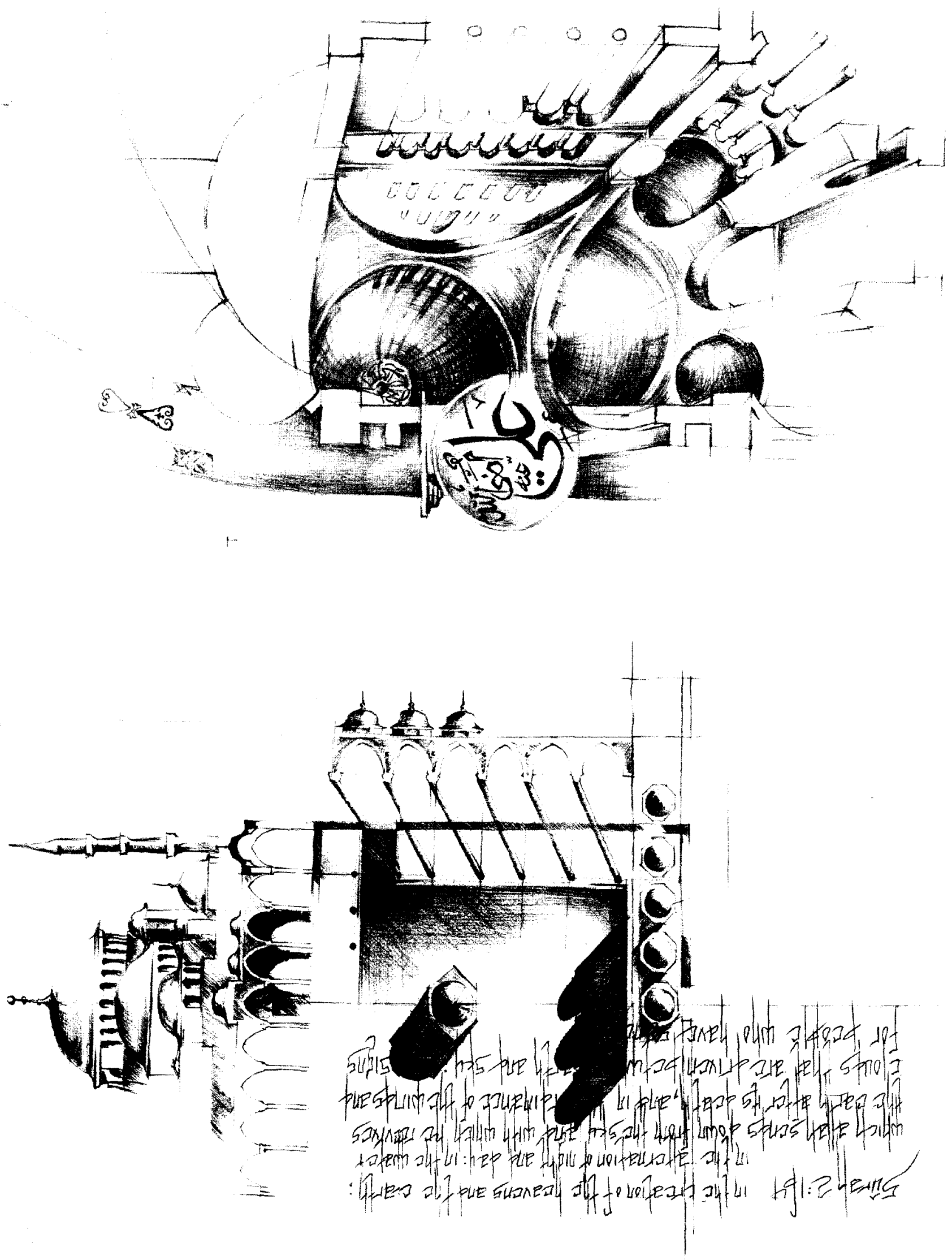

Reproduced with permission of the copyright owner. Further reproduction prohibited without permission. 


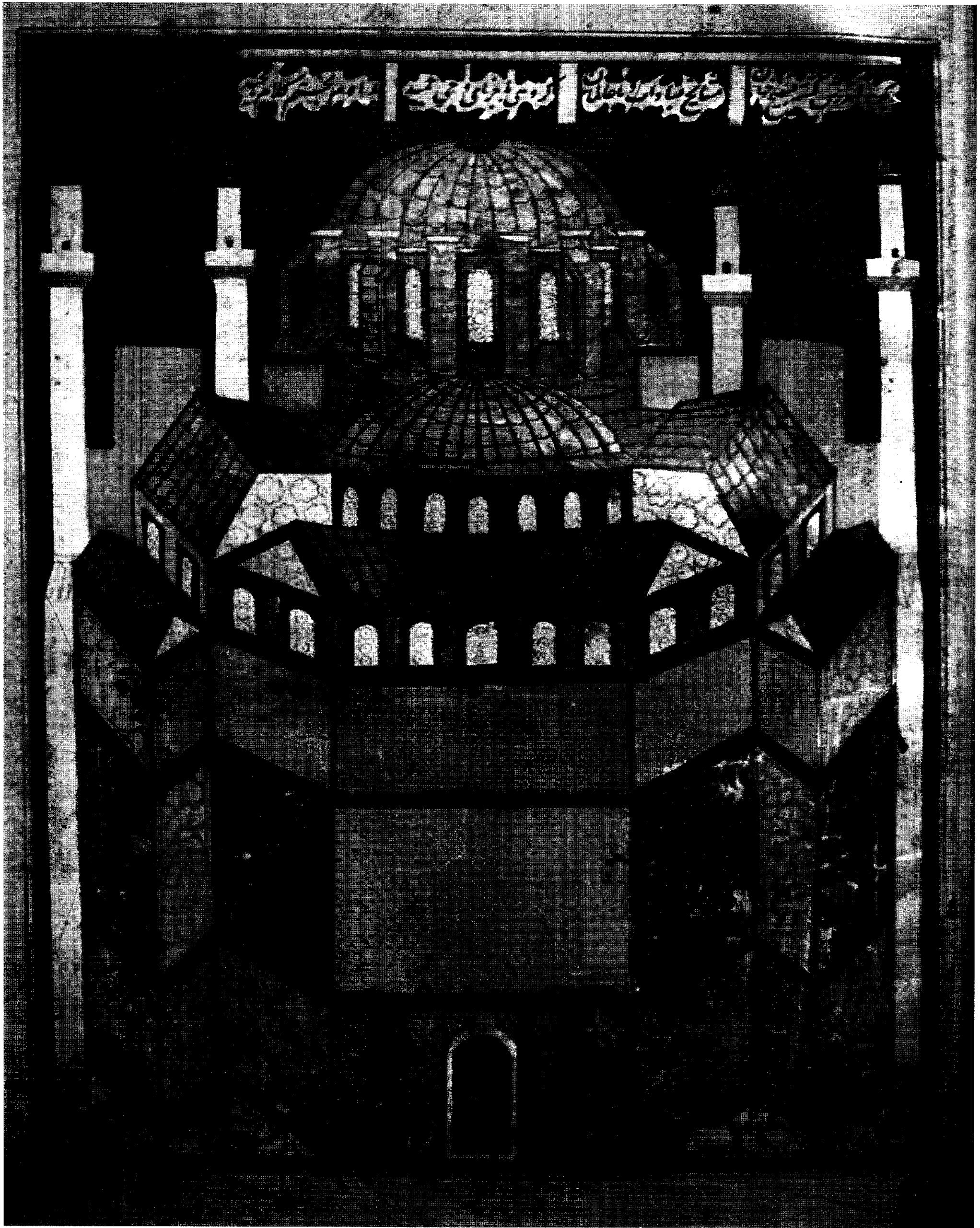




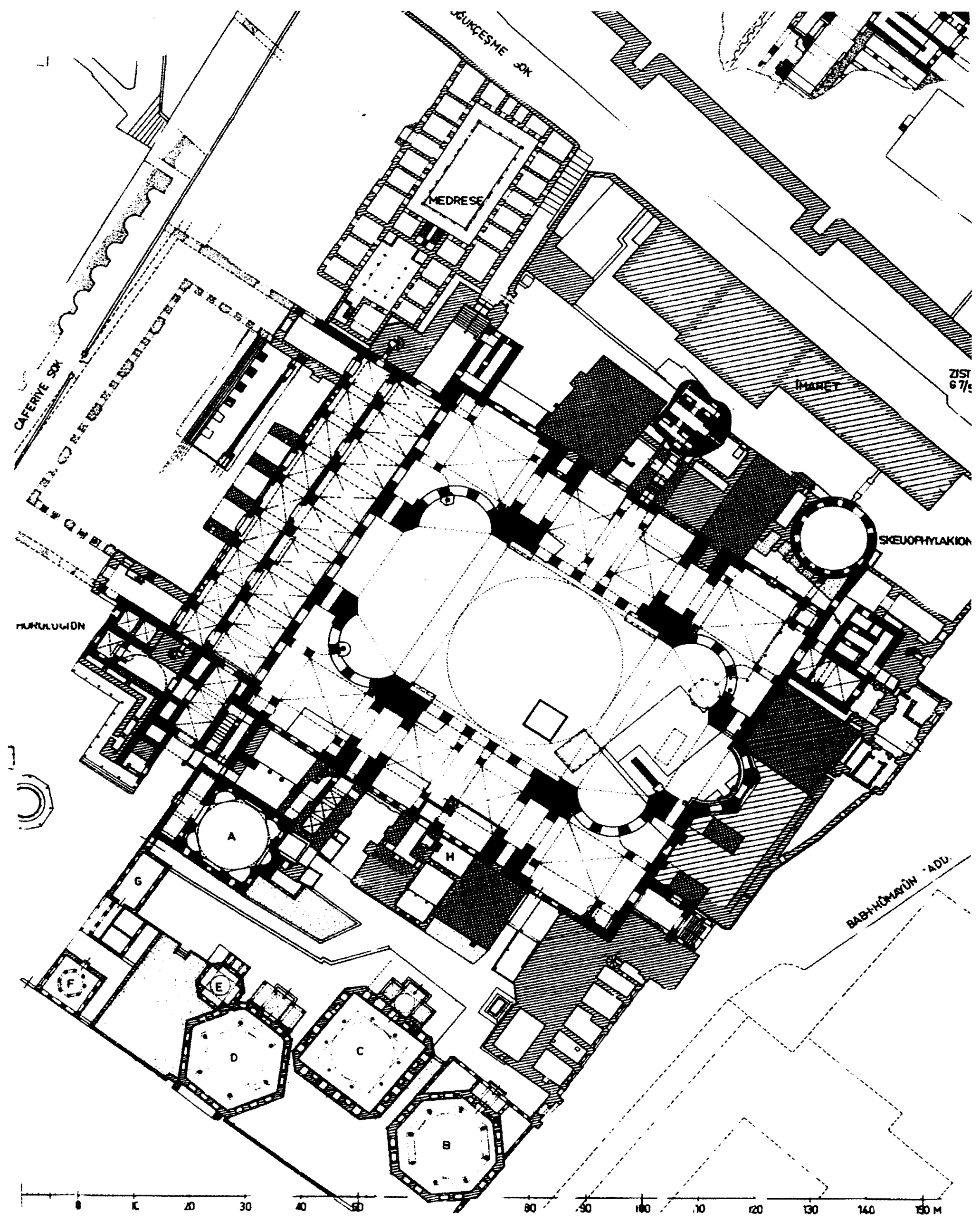

Fig. 39 


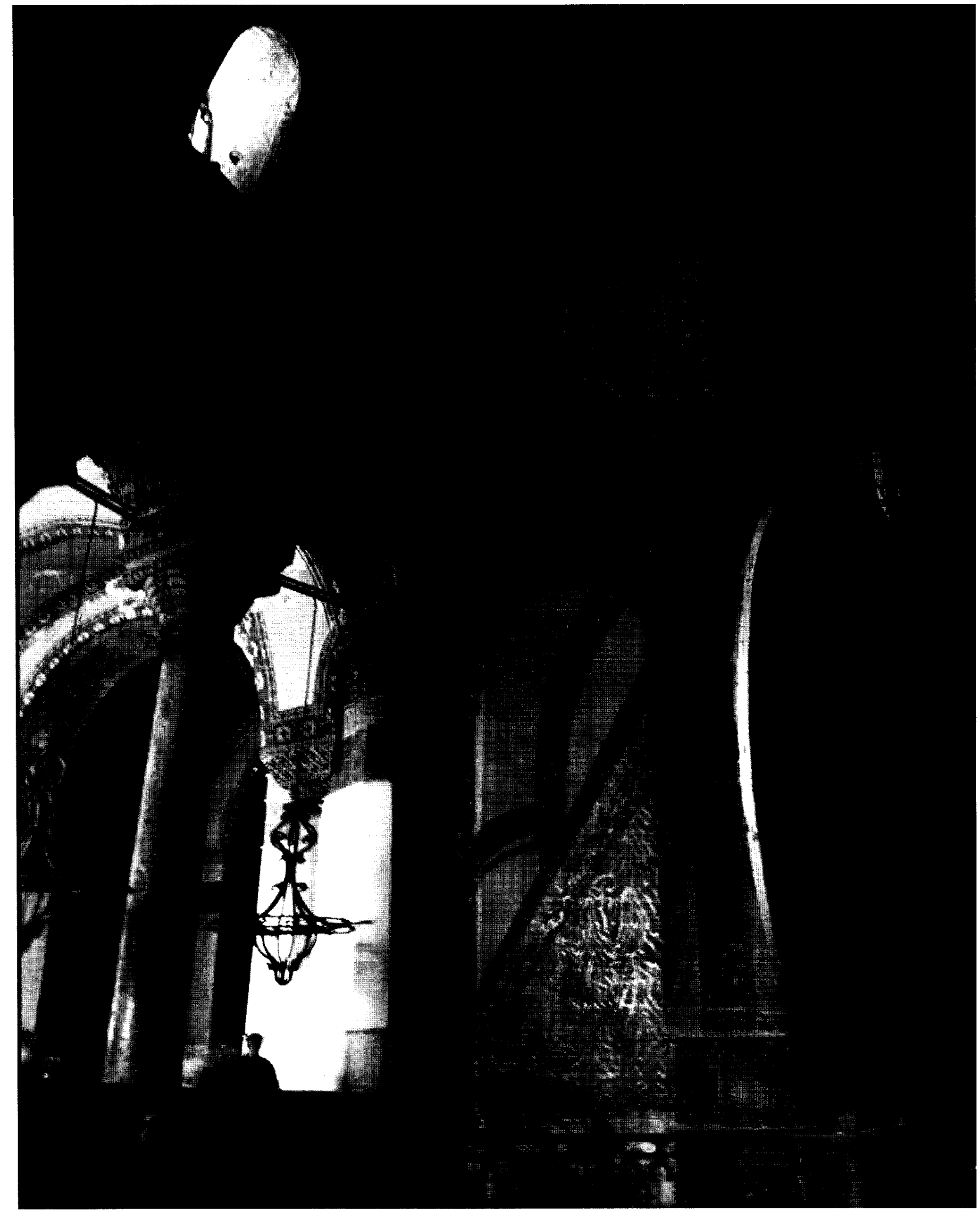


beyond the surface of the architecture and into imaginary depth. The images carve allegorical space from the column and reveal the fundamental theological and spatial concept of the Abrahamic faiths.

The Allegorical space represented in the Santa Maria la Blanca synagogue/ church and Transito synagogue/ church, El Cristo de la Luz mosque/ church and the Ayasofya church/mosque reveals a shared Abrahamic design philosophy. The philosophy is rooted within the early theological representation of the faiths, discussed initially as "Revelation" language within the Abrahamic sacred texts, and later as allegorical imagery. The manifestation of Allegorical space through the fusion of architecture and allegorical imagery is, in part, a means of representing the unique spatial framework of the Abrahamic mythological universe. The architecture reveals Abrahamic theology as it is perceived, interpreted and imagined. This architectural design philosophy is latent within the early imagery that informs the spaces of the Dura-Europos synagogue and house church, and the Ka'ba. Further, it remains present through the development of the architecture of the Abrahamic faiths as mode of housing the revelation of God and as a means of reconciling the divided realms of the Abrahamic universe. 


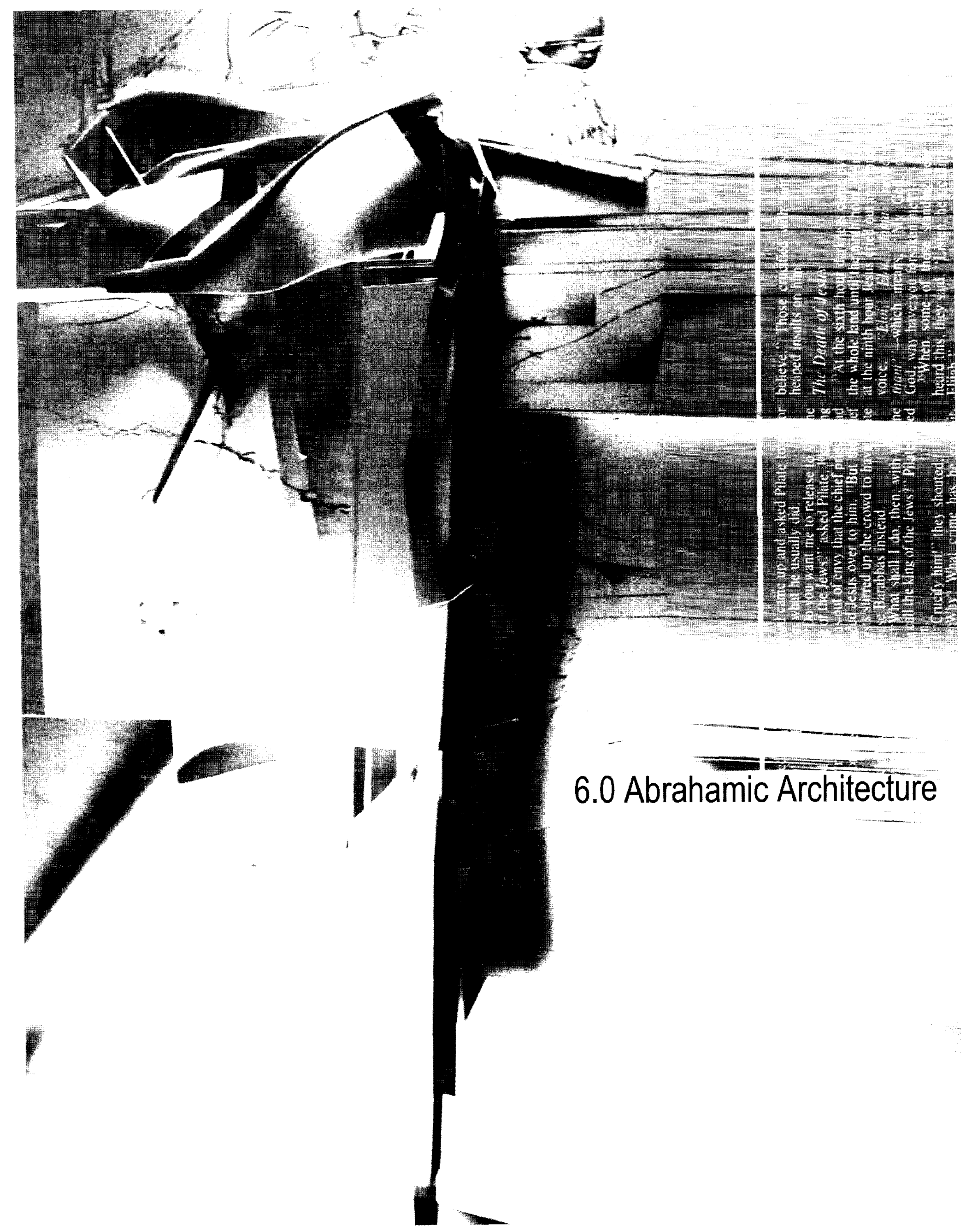




\subsection{Abrahamic Architecture:}

\subsection{Mar Elias University}

In the shadow of contemporary divisions among the Abrahamic faiths the Mar Elias Educational Institution was formed in the village of Ibillin, Israel as an effort to mend relations among Jewish, Christian and Muslim communities through worship and education. The Mar Elias College is in the process of attaining university status. With this distinction, the Mar Elias University (MEU) will require a campus along with several new facilities. The programme of the MEU includes a library, student centre and residence, and university administration. The University also requires buildings to house the departments of Peace studies, Theology and Holy Land studies, Architecture, Communications and Marketing, Computer science, Environmental science, Engineering, Medicine, and Political science. The unique composition of interfaith educational programmes at the MEU results in relatively few architectural presidents from which the design of the university could emerge from. The research and design of this thesis was perused to that end, investigating interconnections within the theological representation of the Abrahamic faiths as a means to design an Abrahamic architecture for MEU.

The site of the proposed MEU is located on the south face of a hill adjacent to the village of Ibillin (Fig. 41), the dwelling place of about 7,000 Arab Christians and Muslims. The village resides north of the valley of Armageddon centred between Nazareth, a predominantly Arab city and Haifa, largely home to Jewish Israelis. Stone foundations walls discovered under the churches, mosques and houses that shape the hill top landscape (Fig. 42) extend the history of the village to the Byzantine Empire (Fig. 43,44). The hill into which the university is embedded is marked by field stone walls made from clearing the soil for the numerous olive trees that cover the 


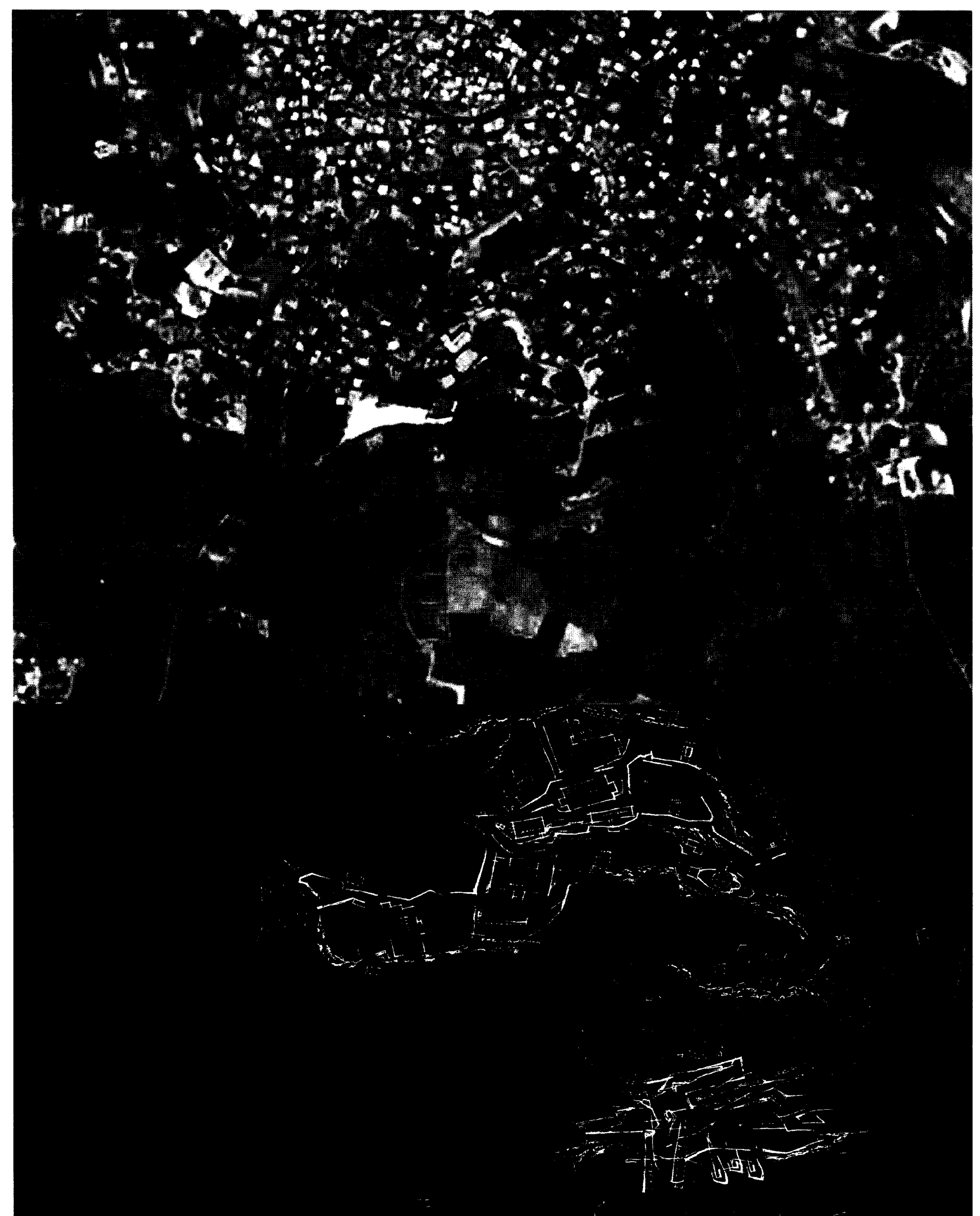




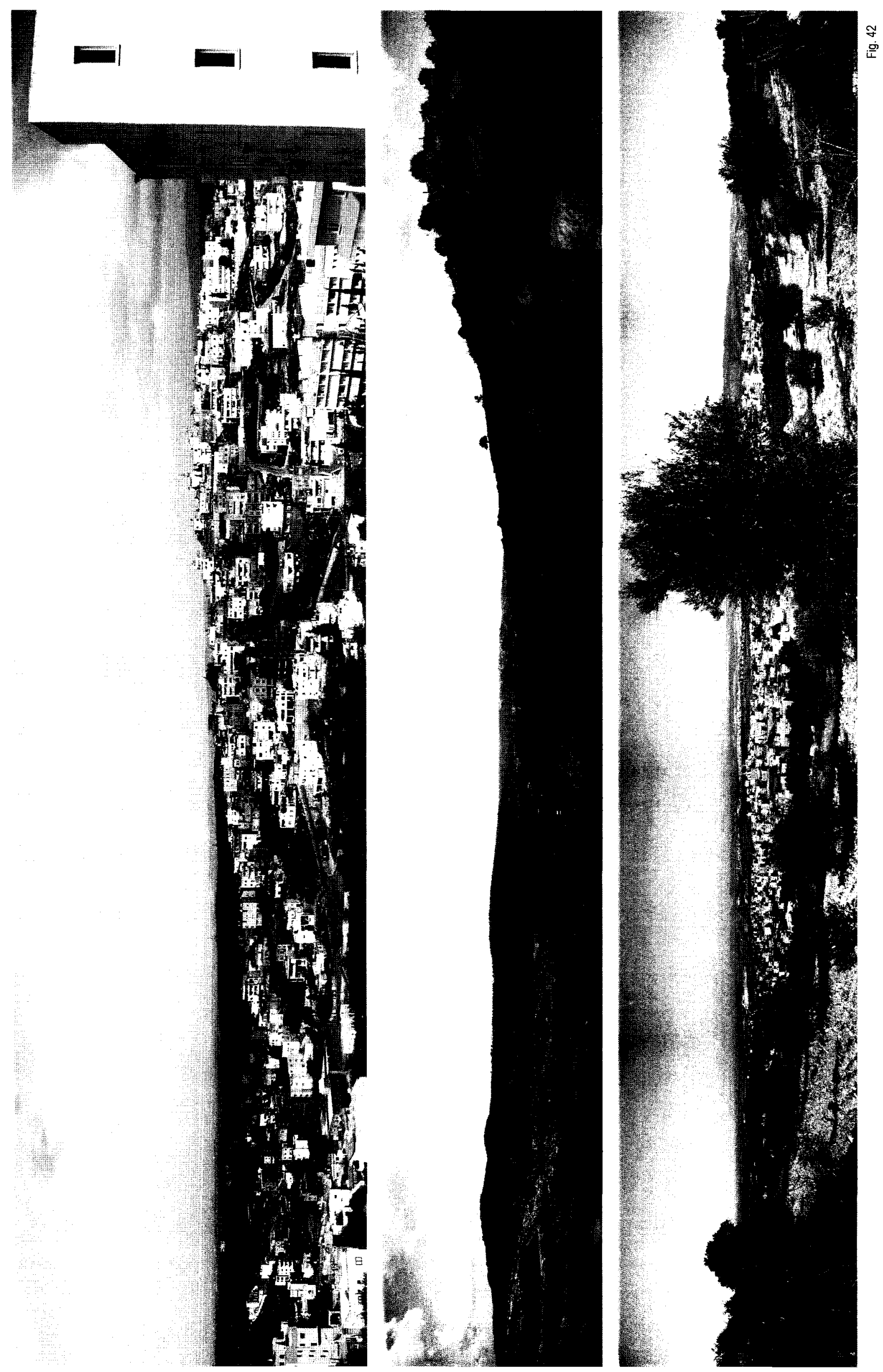




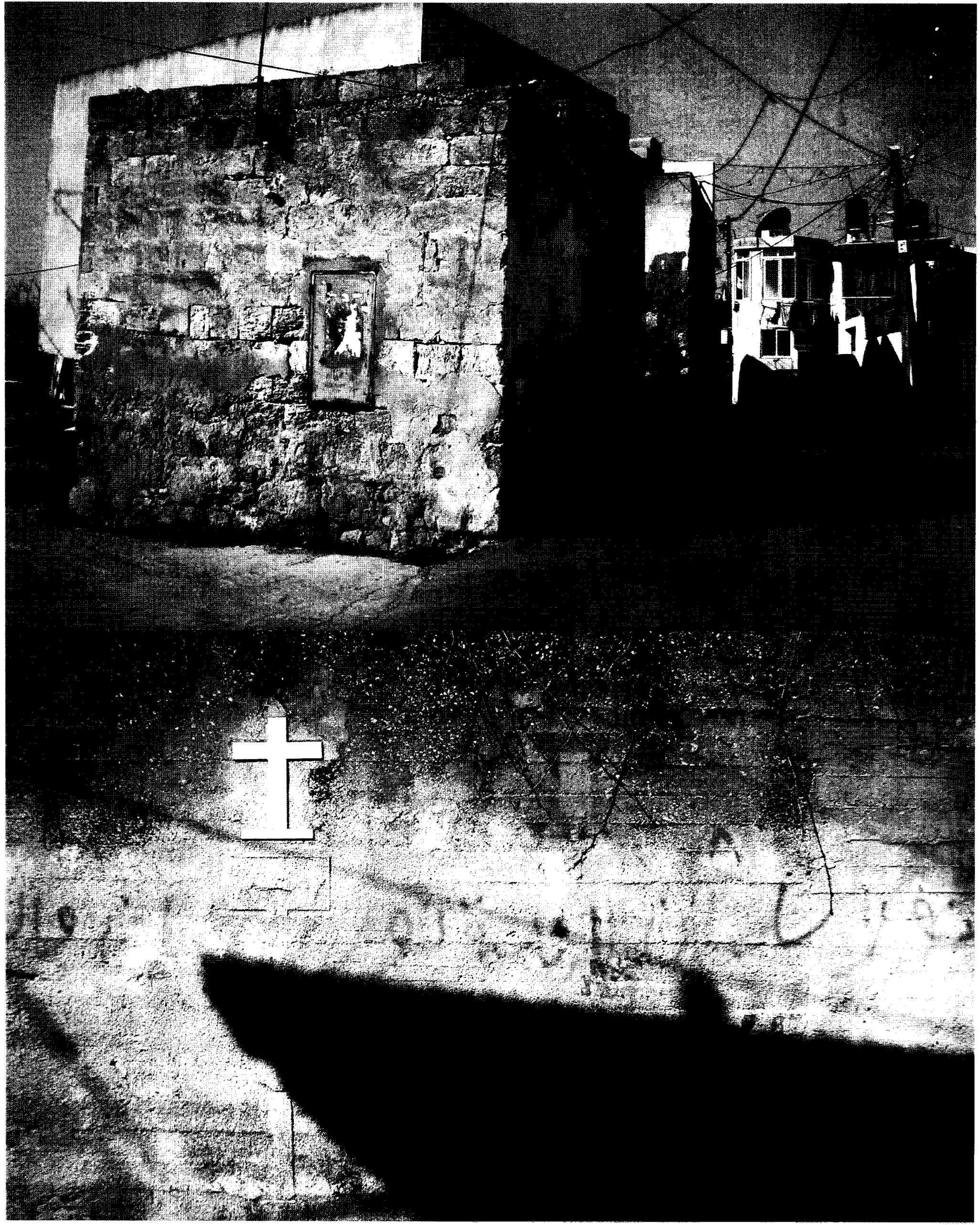




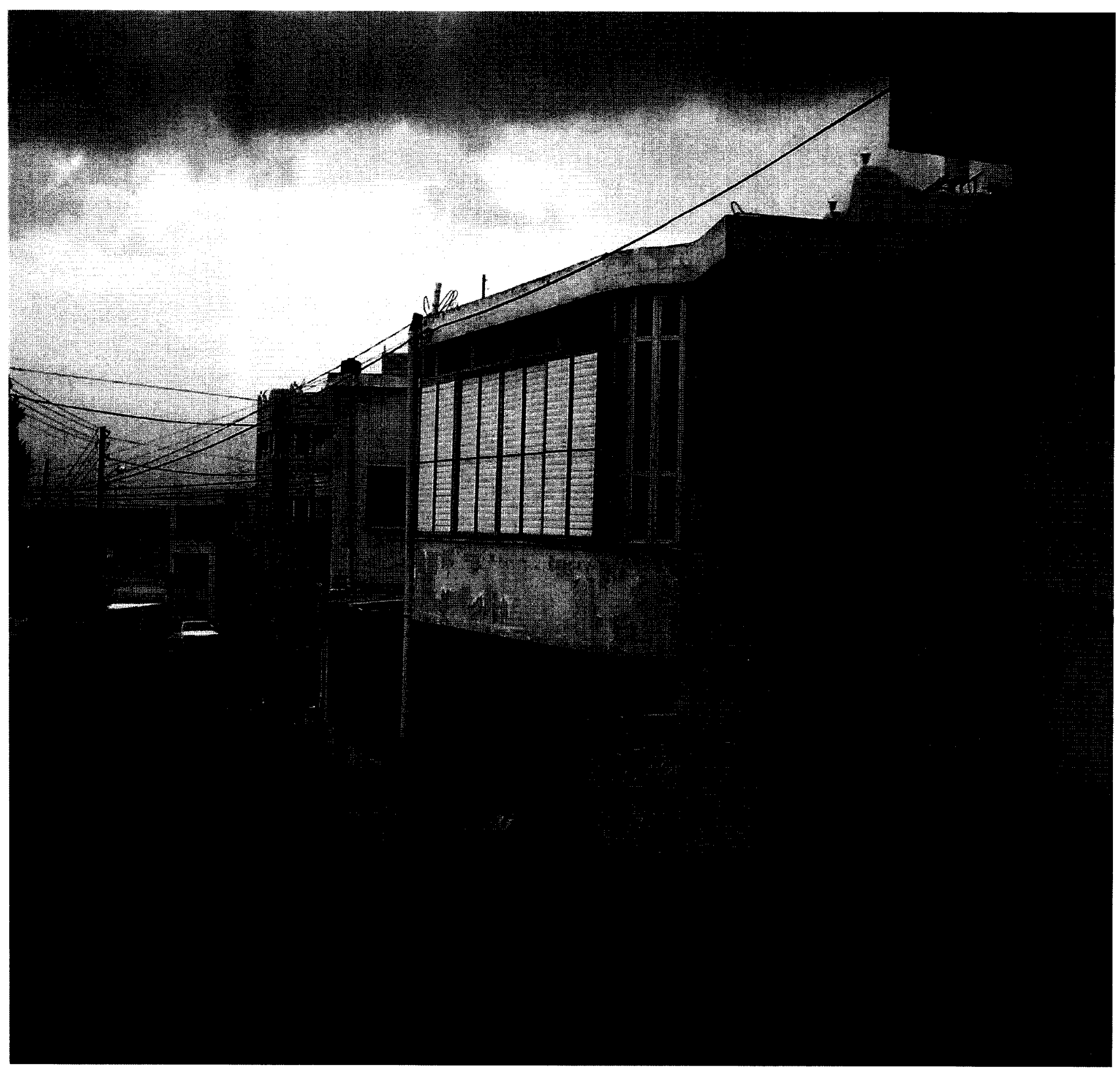

Fig. 44

Reproduced with permission of the copyright owner. Further reproduction prohibited without permission. 

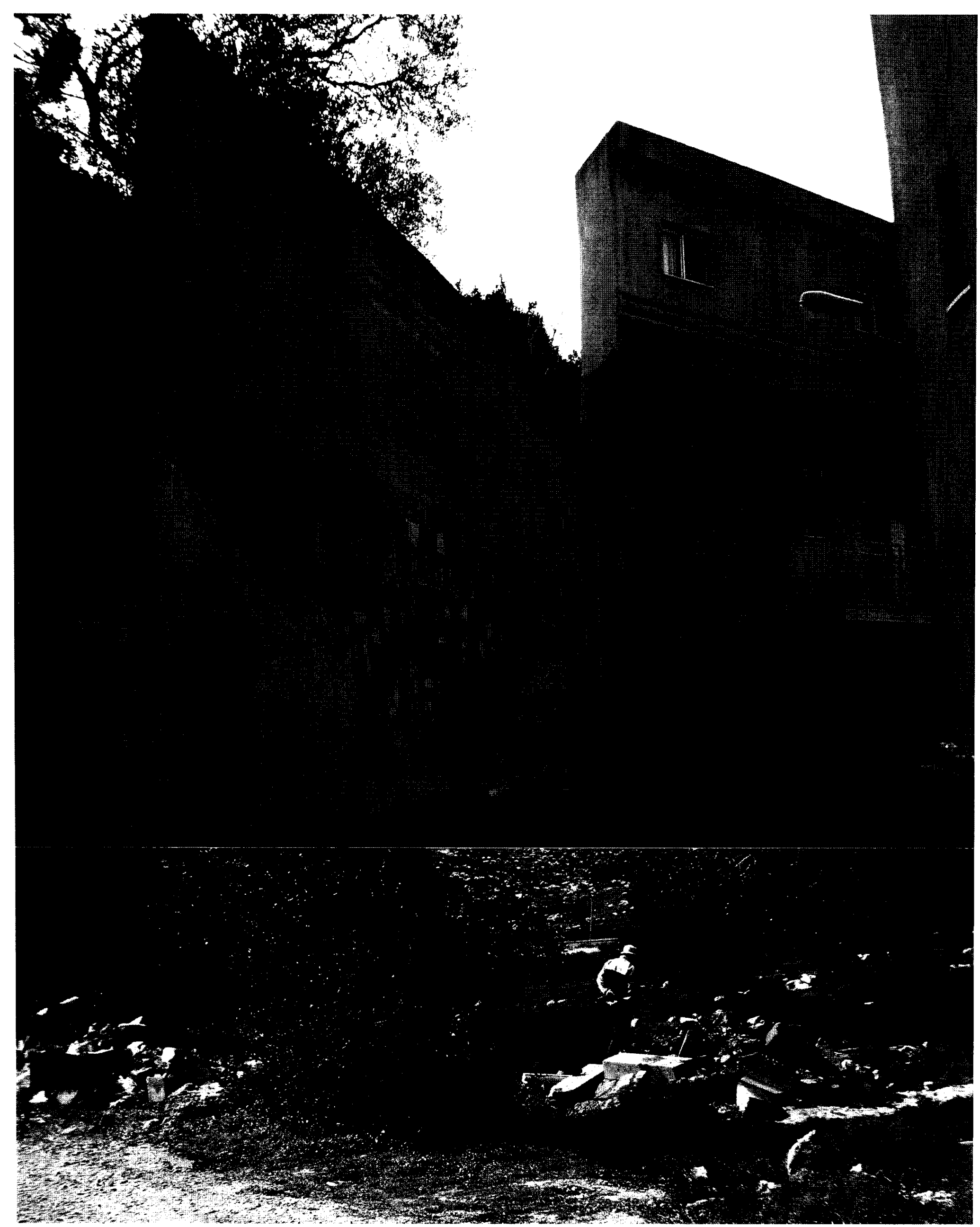

Fig. 45

Reproduced with permission of the copyright owner. Further reproduction prohibited without permission. 
hill. The valley to which the site descends into is coloured by long grass, flattened in part, retaining the path traced by shepherds and their flocks (Fig.45).

\subsection{Architectural Representation of Abrahamic Allegorical Space}

The architectural design of the MEU unfolds as an investigation of allegorical space. he thesis investigation of the

The interconnections discovered within the theological representation of the Abrahamic faiths forms the foundations from which the design of the MEU emerges. The underlying interpretive framework of the sacred texts discussed earlier as "Revelation" language encourages the translation of Abrahamic theology into allegorical forms of imagery and architecture (Fig. 46, 47,48 ). The faiths interwoven revelation (Appendix $A, B, C$ ) is drawn from interrelated imagery, narratives and allegories within the sacred texts and translated into allegorical theological/architectural drawings (Fig. 49). The allegorical space of the drawings informs the location of the universities programs, and the tectonics of the architecture. The interwoven fabric of physical and theological space created from interpreting Abrahamic revelation through the various mediums is similar to that found within the faiths early remnants. The allegorical space of the university is represented through three-dimensional drawings or image mapped architectural modeling. The models represent both the physical and imagined dimensions of the architecture, and reveal through there materiality and composition of allegorical space the Abrahamic mythological universe (Fig. 50,51). The spatial language of the MEU unfolds similar to "Revelation" language where the boundaries delineating material and allegory dissolve -the architecture seamlessly flows from material to imagination revealing the latent connections among the Abrahamic faiths to facilitate their reconciliation. (Fig. 52, 53, 54, 55, 56). 
The threshold of the MEU is denoted by the separation of the earth and the sky, the School of Theology floats prominently above the entrance and touches the earth with a single column. The column descends into water divided by an image of Joshua and the Ark of the Covenant. The cloud of folded metal floats unrestrained over the waters while its surface and the ground are stained with rust, or the blood of the lamb. Metal pins pierce a soft wooden frame adorning the rusty surface which is cut to reveal Christ's body in tension. The threshold witnesses the last breath of the lamb and a sea of red is opened to reveal a mirror of heaven. Standing in the void is Abraham; his torn garment is drawn to separate corners of the earth. One leads to a desert horizon where memory is written in sand. The other, to rivers of blood and a heavenly city made from a container of ancient dreams. The School of Theology rotates around an invisible column and dissolves into the flowing horizontal walls of the School of Architecture which reshape the earth. 

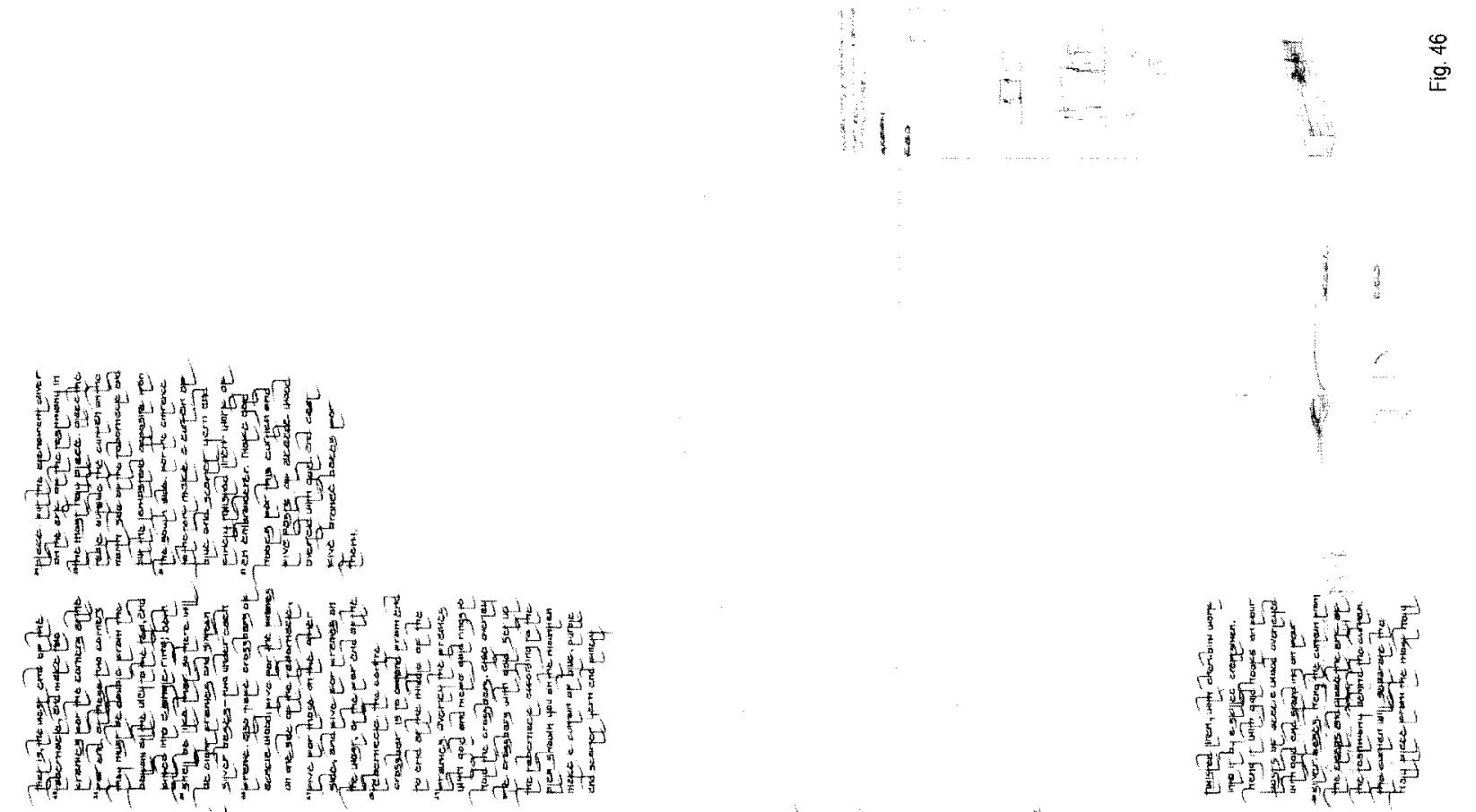

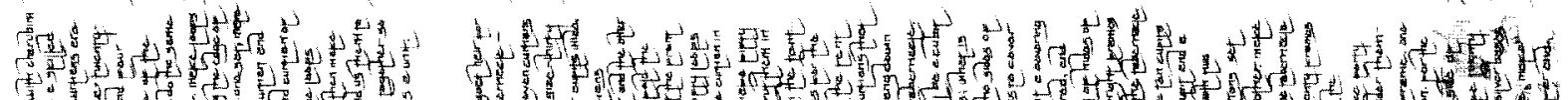

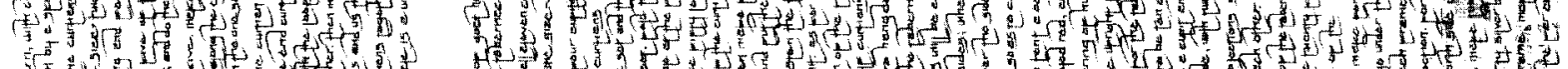
5.

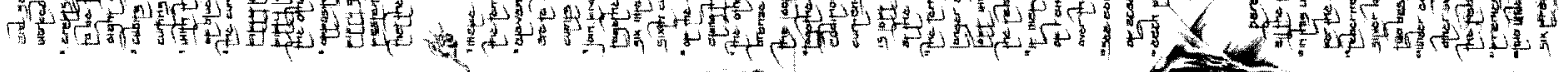




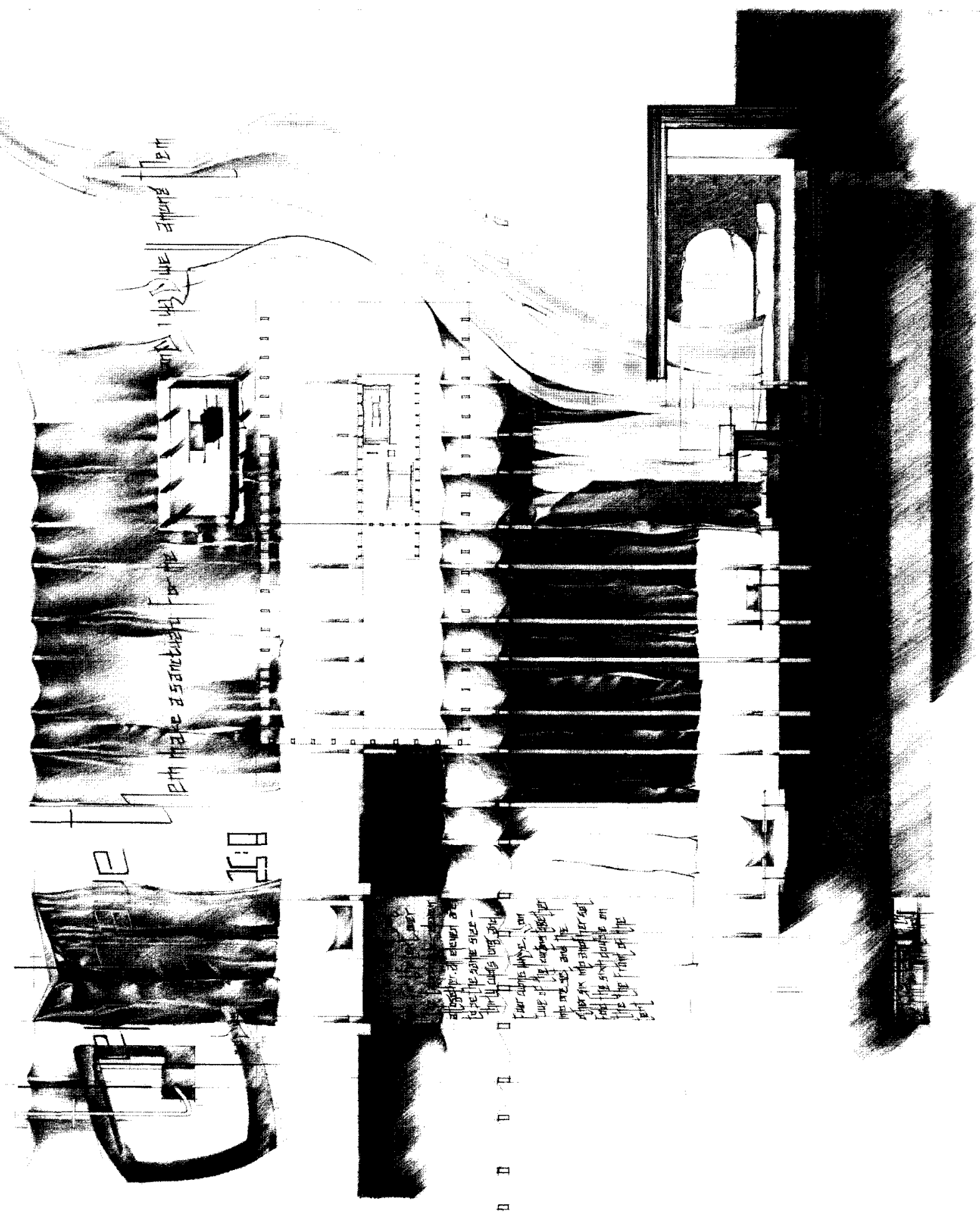

Reproduced with permission of the copyright owner. Further reproduction prohibited without permission. 


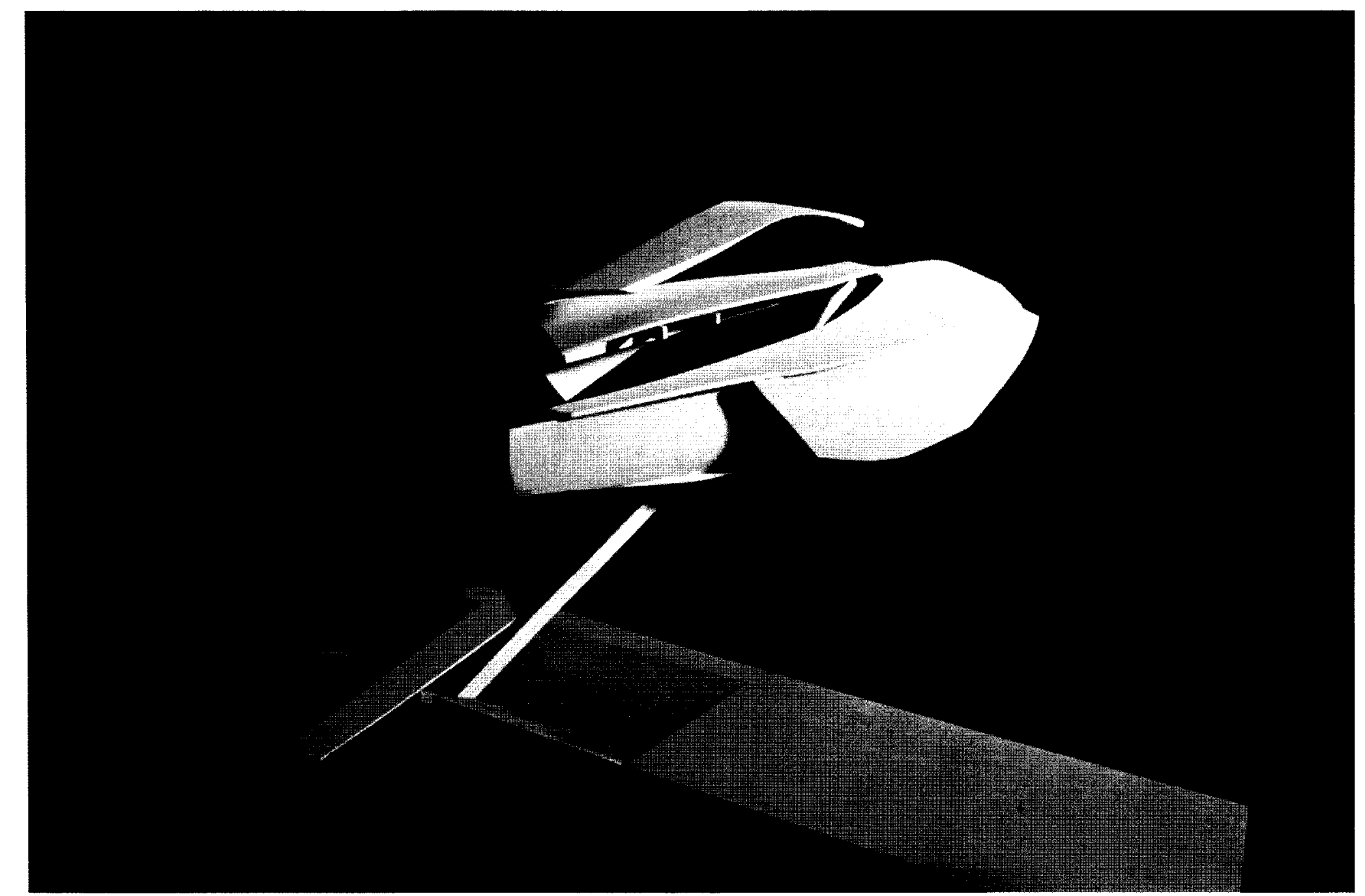

Fig. 48

Reproduced with permission of the copyright owner. Further reproduction prohibited without permission. 


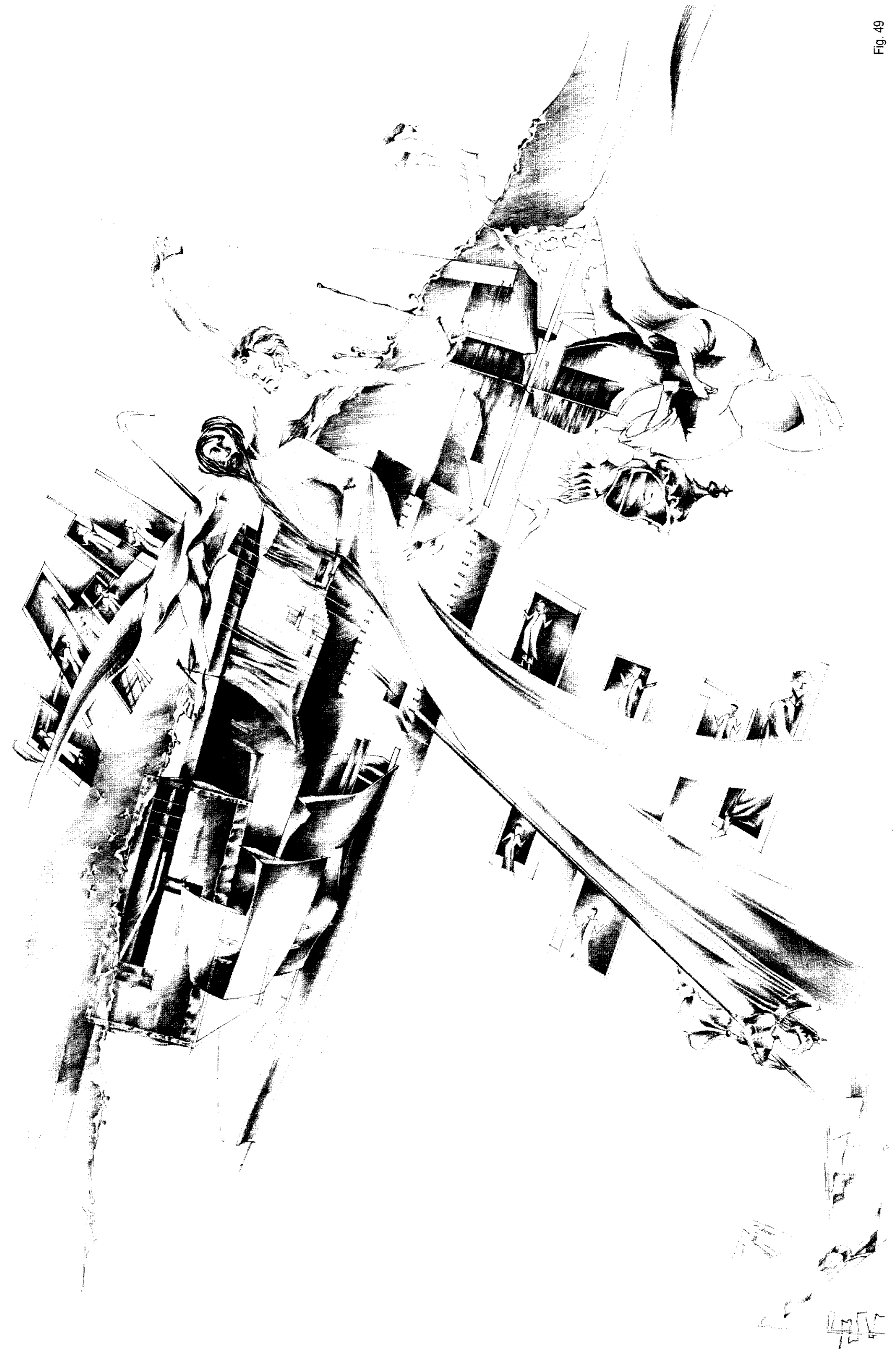




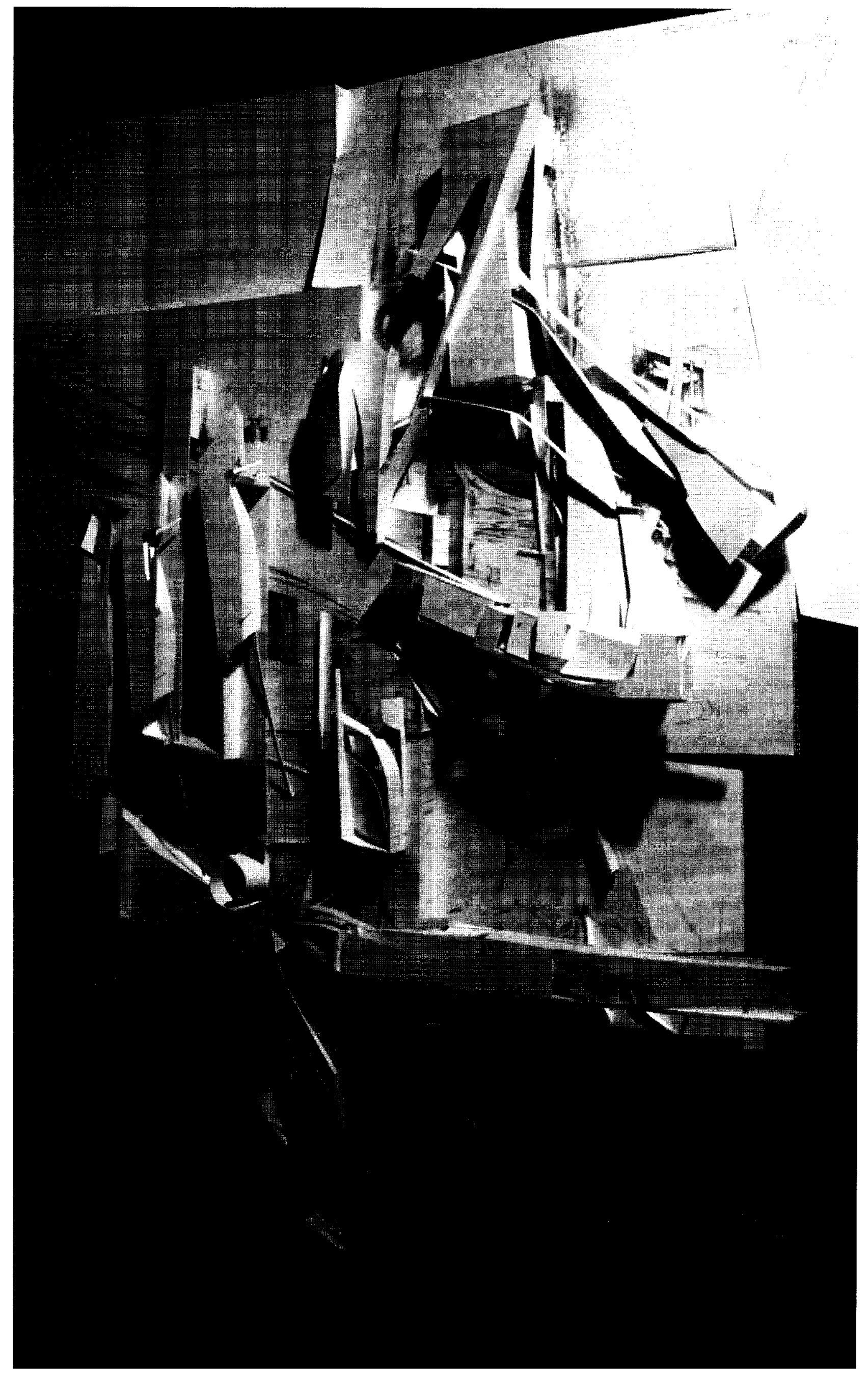




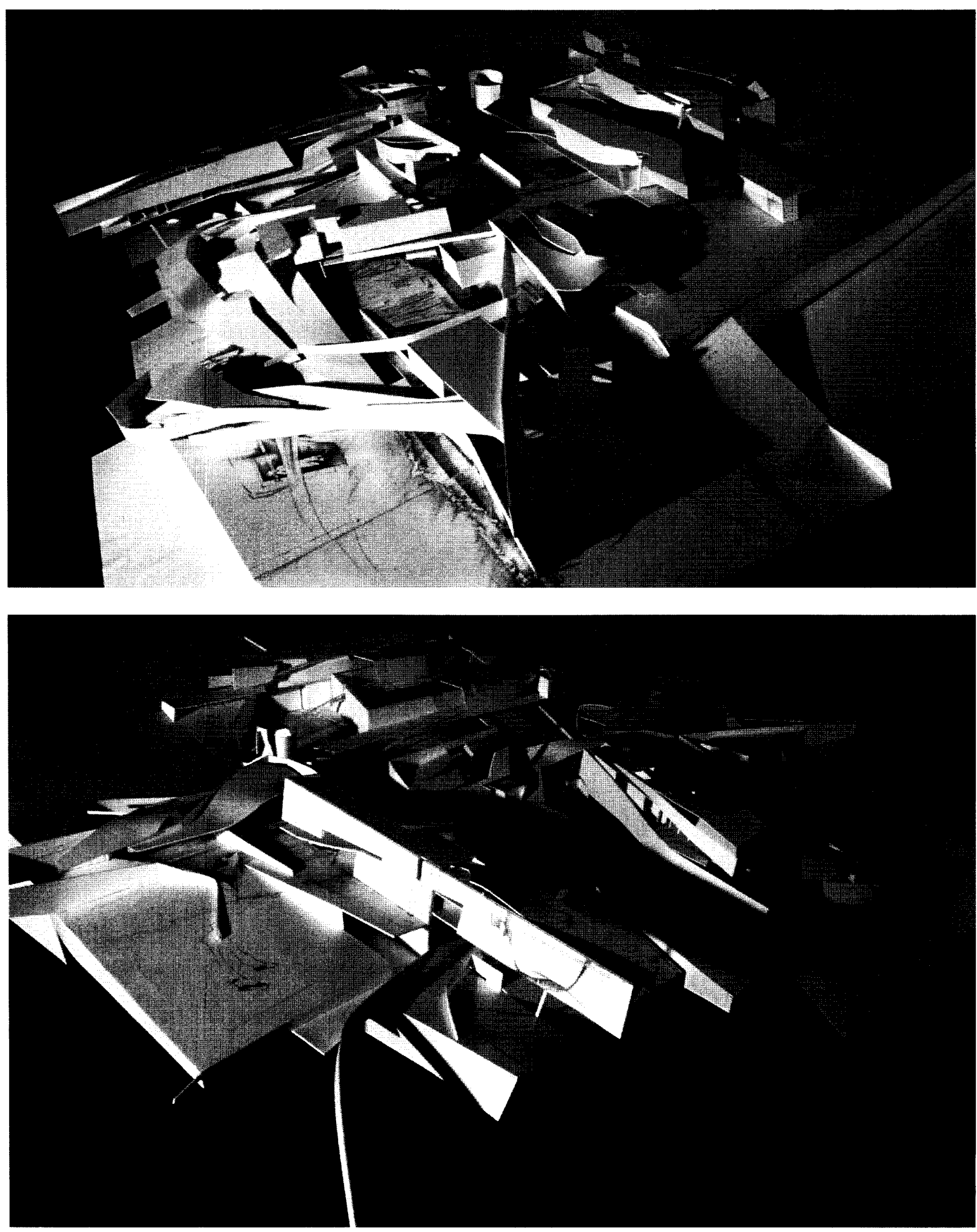




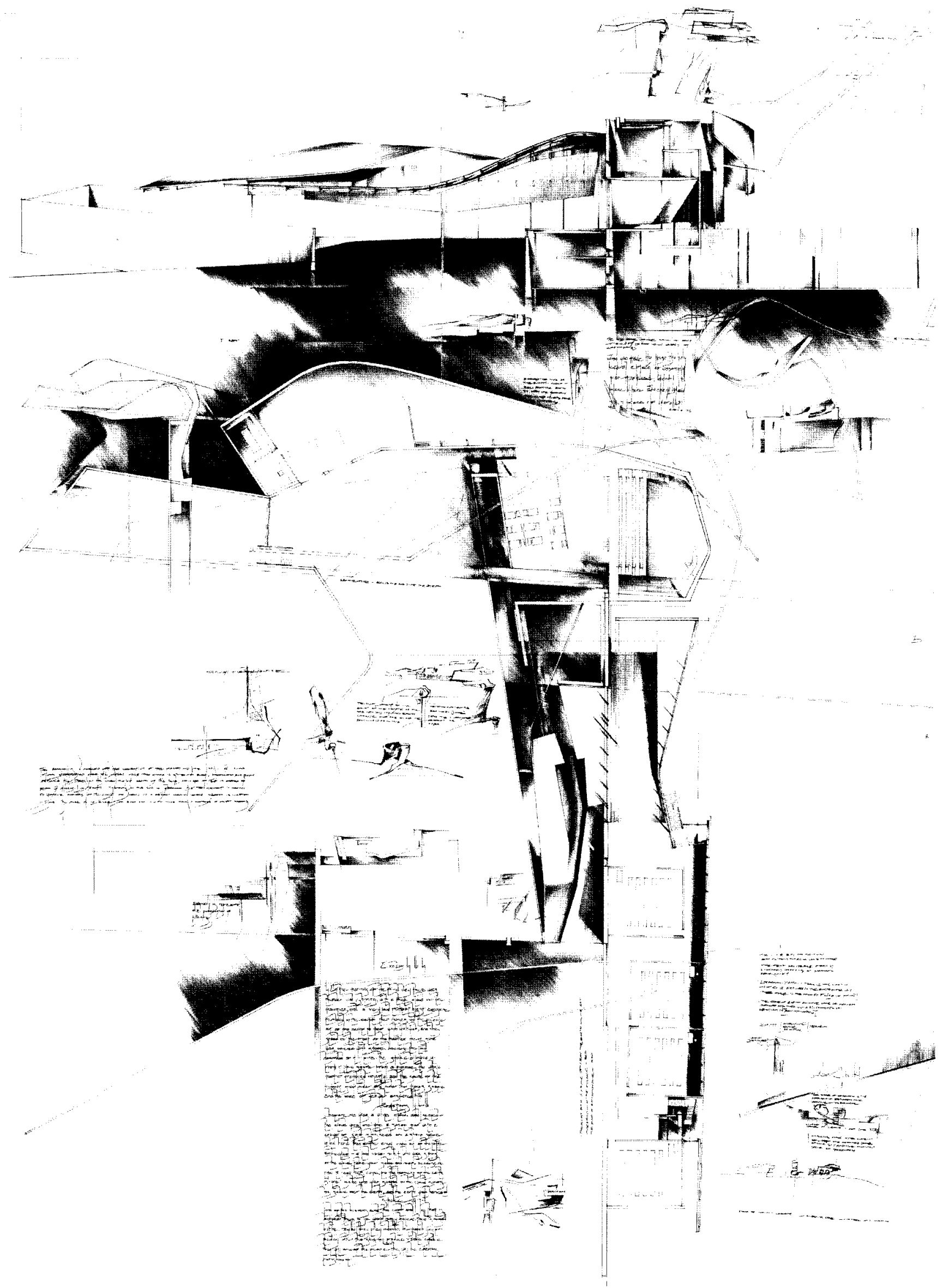




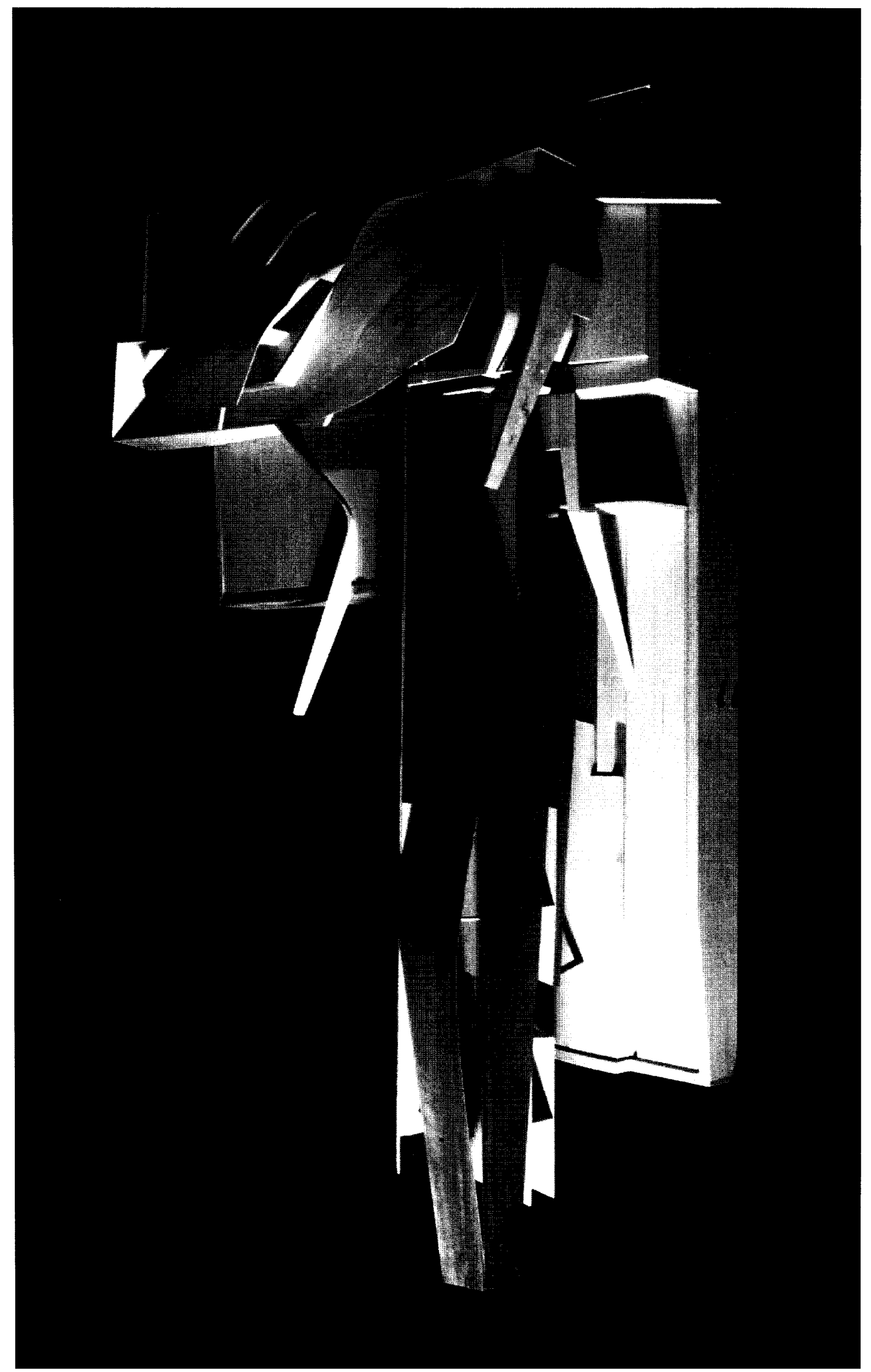



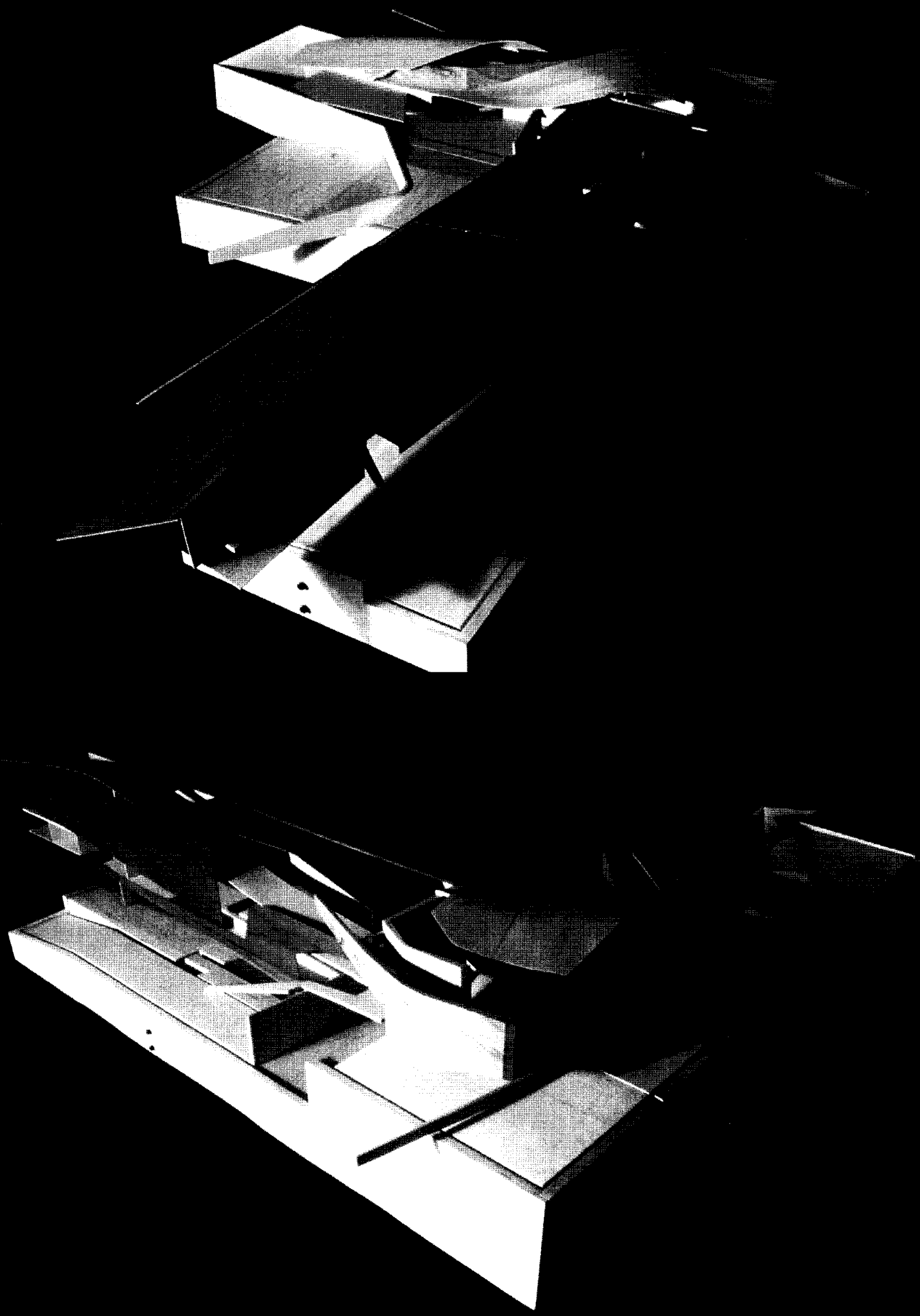


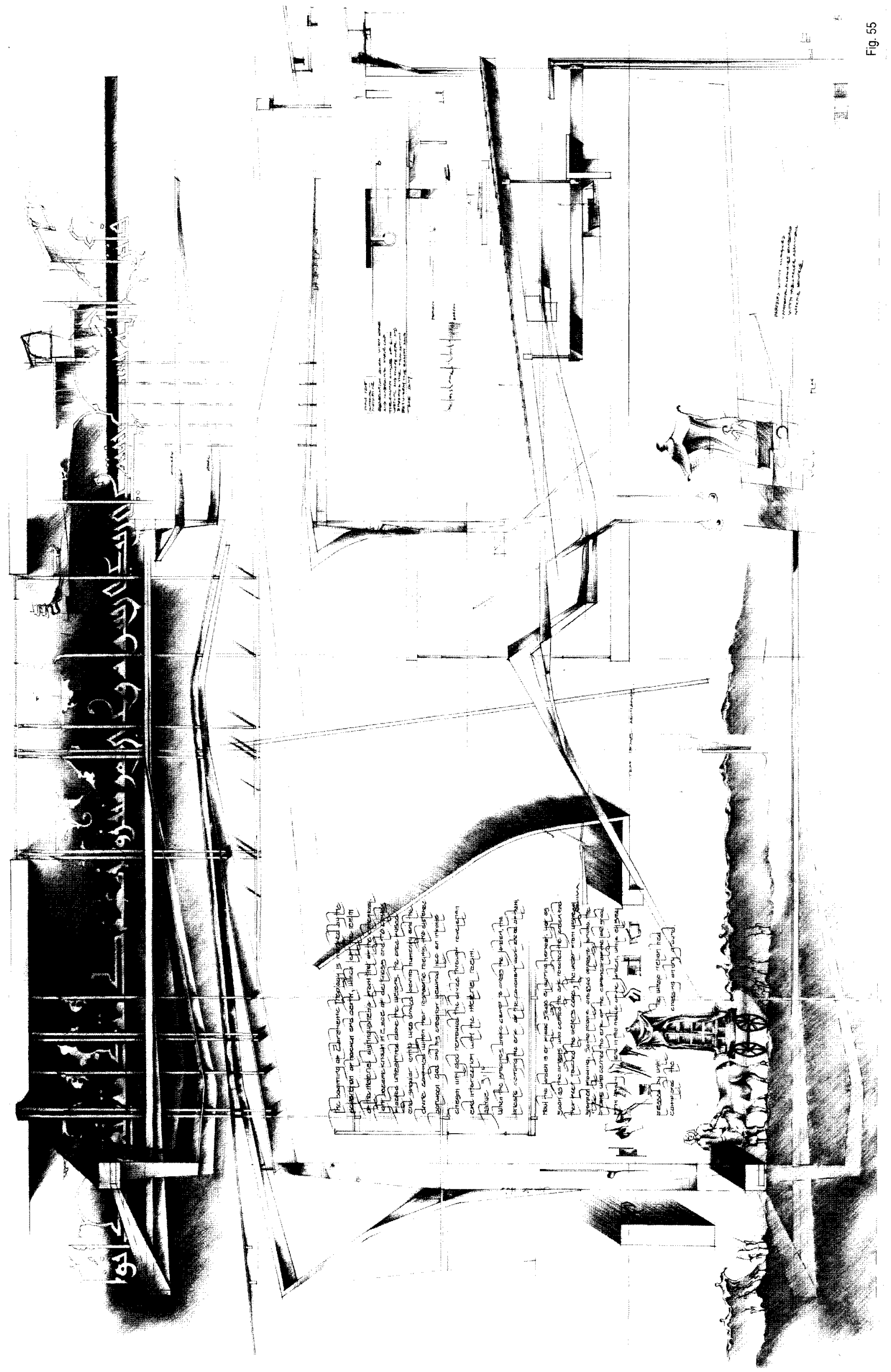



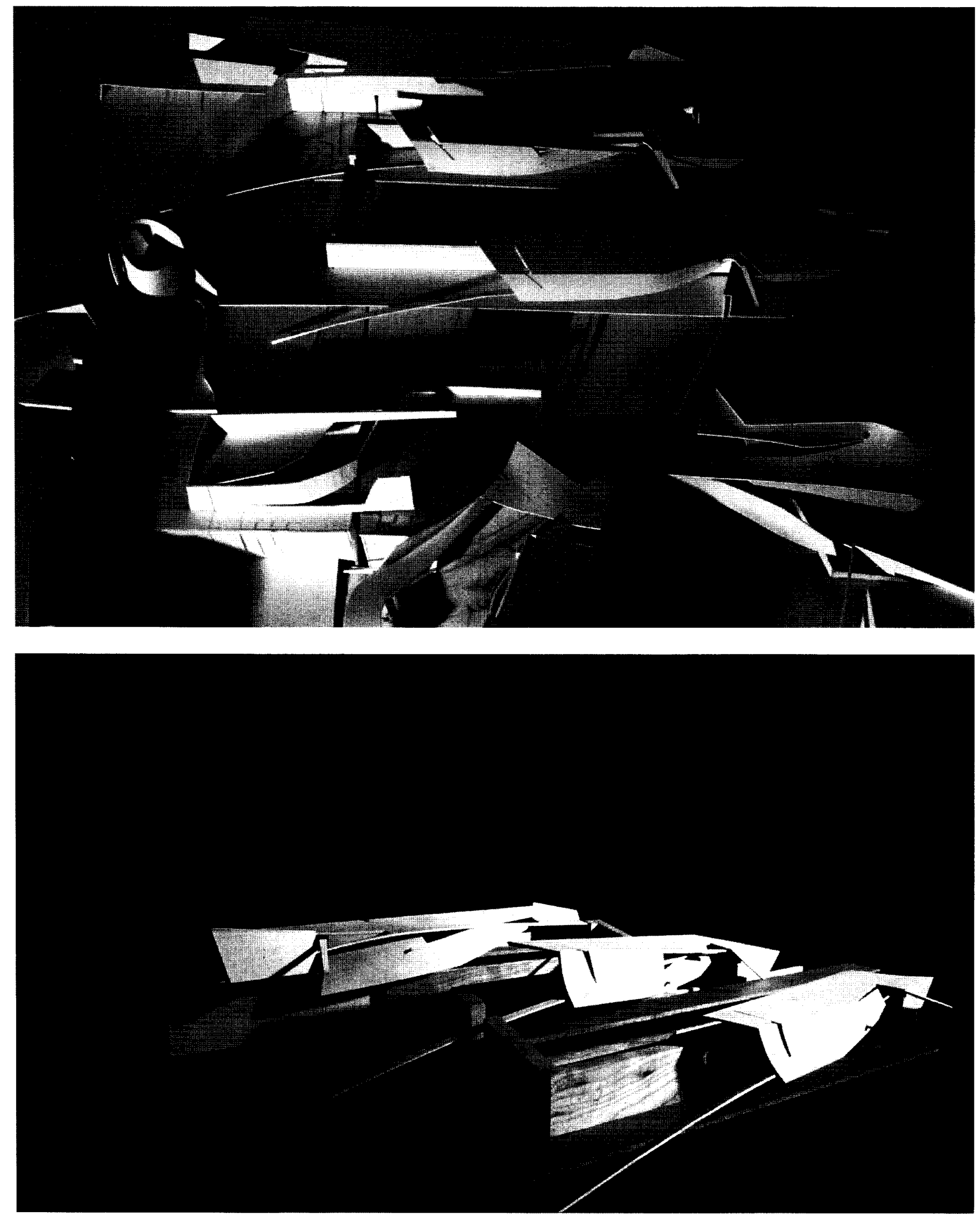

Fig. 56

Reproduced with permission of the copyright owner. Further reproduction prohibited without permission. 


\section{Appendix A}

\section{Torah}

\section{Exodus}

After identifying the Israelites as the people of the Lords kingdom, the book of Exodus describes God leading them out of Pharaohs hand in Egypt where they were bound by slavery.

Among the Hebrews was born a great leader and prophet, Moses was a Levite child saved from persecution by the Pharaohs daughter who drew him from the Nile river. Moses was raised by the ruling family of Egypt, but he soon returned to the Hebrews and married Zipporah, a Levite. While tending the flock of his father-in-law Jethro, the angel of the lord appeared to Moses as fire within a bush. The lord was identified as the God of his father, the God of Abraham, Isaac, and Jacob. The Lord revealed to Moses his plan to free the Hebrews from their strife and lead them to the land of flowing milk and honey. Pharaoh's unwillingness to free his slaves subsided after the Lord intervened with ten plagues. Inspired by the Lords revelation Moses lead the Hebrew's from Egypt through the Red sea to the base of Mount Sinai, where he was called by God to the top of the mountain. From a dense cloud of fire and smoke God delivered, through Moses the Law to govern his nation. (Qur'an: Sura 2:47-53) While Moses was absent Aaron and the Hebrews molded a golden calf to worship. Upon Moses return to the camp he became outraged at the sight of the idol and destroyed the stone tablets containing the Law. The Justice of the Lord became known when God destroyed an entire generation void of faith. (Qur'an: Sura 2:54) While in desert the Israelites became thirsty, they asked the Lord to provide them with water. Moses was told to strike a rock with his staff and water enough for the twelve tribes flowed from the stone. (Fig. 1) (Qur'an: Sura 2:60) Despite the fragility of their faith, God loved his people and asked the Hebrews to build a house for him so he could dwell among them in the desert. The Tabernacle was constructed according to Gods instructions along with a sacrificial alter, an ark, to house the stone tablets of the covenant and garments for Aaron the priest and his sons who were responsible for burning the lamps through the night. The book of Exodus ends when the glory of the Lord descends from heaven in a column cloud to inhabit the inner sanctuary of the Tabernacle. (Fig. 47)

\section{Leviticus}

The book of Leviticus begins with God calling Moses to the tent of meeting where he delivers instructions regarding the various offerings the Israelites are to present to the Lord in order to atone for their sins. Ceremonial traditions and the garments to be adorned by Aaron and his sons are identified by God along with which animals are to be eaten and which ones are unfit for the Israelites. The ceremonially unclean, women who have just given birth or menstruating or those with skin infections or burns are told not to enter the sanctuary. They are to be examined by the priests who will determine if they need to be isolated until they heal. Nadab and Abihu, Aaron's sons deviate from the tradition the Lord set forth and find their punishment in death. Following their death God informs Moses that Aaron shall only enter the most holy place behind the curtain on the Day of Atonement (Yom Kippur) where above the atonement cover God will appear in a cloud. The Lord instructs Aaron to bring with him a bull for a sin offering and a ram for a burnt offering and 
promises if the ceremony is orchestrated according to Gods commanded the Israelites will be forgiven. It is made known to Aaron if he defiles the lord and enters the most holy place on any day other then the tenth of the seventh month he will die.

\section{Numbers}

God speaks to Moses from the tabernacle and tells him to take a census of the Israelite community. The people were divided according to their tribe and all men 20 years of age or older who were able to serve with the army were counted. Excluded from the census were the families from the tribe of Levi. The Levites were invited to attend the tabernacle of the testimony and maintain its furnishings, they were instructed to move the tent wherever the Israelites traveled and setup their camp around the tent. The Levites were set apart in order to minister to the Israelite tribes; they were made ceremonially clean for God as a replacement for the first born animals and sons that were promised to him following the Israelites exodus. God commanded the Israelites to respect the Passover and make themselves clean in front the Lord as he descended upon the tabernacle.

The Israelites grew tired of the manna that God provided for them to eat while on their journey to the Promised Land, they demanded meat and displeased God by suggesting that they were better served by the Pharaoh in Egypt. God responded to their cries and provided them with meat.

Disappointed with their faith, God warned the Israelites that anyone that saw his glory in Egypt and in the desert will fall before they ever see the land of milk and honey. Nearing the end of their journey through the desert and following the plague brought upon the Israelites for being seduced by the Moabites, a second census was taken by Eleazar the priest and son of Aaron on the shore of the Jordan. The land God had promised the Israelites was divided among the twelve tribes and given to them as an inheritance.

\section{Deuteronomy}

With God's hand the Israelites defeated Sihon king of the Amorites and the sixty cities of Og, king of Bashan. Following the destruction of these nations God summoned Moses from the east shore of the Jordan, commanding him to ascend the mountain and view the Promised Land from afar. God reminded Moses that because the people doubted him in the desert he will remain there and never set foot on the land promised to Abraham, Isaac and Jacob and given to the Israelites.

Moses returned to the twelve tribes to commission Joshua to lead the Israelites across the Jordan. Before the Israelites reached the Promised Land Moses reminded them of Gods Law given to them on stone tablets from the burning mountain, and of his love for the Israelites and the many miracles God performed in the desert during the forty years he lead them out of Egypt. God assured the Israelites that He is one, and they are to love the lord God with all their heart, soul and strength. The commandments given to the Israelites are to be honored and recited to their children, God urged them to tie them as symbols to their hands and foreheads and write them on the gates and doorframes of there houses. Moses reminds the Israelites that when they reach the land west of the Jordan they are to follow Joshua and the leadership set up for them in the desert and perform 
the same offerings and festivals God requested to the generation before them that lay dead in the desert.

The Lord ensured the Israelites after they arrive and settle in their new land the Lord will choose a place as a dwelling for his name, it is there where sacrificial and burnt offerings are to be made. The Israelites are told to build an altar of field stone with no trace of metal. Once the altar is constructed it is to be covered with plaster and the Law as God commanded shall be written in the plaster. Joshua and Moses went to the tent of meeting and God presented himself in a pillar of cloud, where he commanded Moses to finish the book of the law with a song. Moses recited the song to the twelve tribes and ascended the mount Nebo across from Jericho where God told him he would die, and there he was buried.

\section{Joshua}

Following the death of Moses the book of Gods Law was bequeathed to Joshua, who was asked to lead the Israelites through the Jordan to acquire their inheritance. The priests took the Arc of the covenant and lead the Israelites from their camp in Shittim to the shore of the Jordan. God promised Joshua he would make him exalted in the eyes of all of Israel so they would know that the Lord was with him as he was with Moses. God commanded Joshua to send the priests carrying the Arc into the water. The Jordan River was at flood stage during the harvest but at the moment the priests placed their feet in the water it drew back and provided dry land for the Israelites to cross. Just as God opened the Red sea for Moses to escape Egypt so to did he break the water of the Jordan for Joshua and the twelve tribes to reap their harvest. Joshua ordered each of the twelve tribes to gather a stone from the bed of the river and place it in Gilgal where they would serve as a memorial and all the generations that followed would know of Gods love for them.

Lead by the seven priests blowing seven trumpets the armed Israelites were ordered to circle the walls of Jericho on the seventh day they circled seven times and the Lord commanded them to shout, they did and the walls crumbled and the city was taken. All that was contained within its boundaries was anileated except for Rahab, the woman who helped the Israelite spies.

After burning the city of Ai the Israelites built an altar of uncut field stone for God on Mount Ebal as Moses has requested. The Israelites swept through the remaining land and conquered all that dwelled within putting them to the sword. God had fulfilled all that he promised to the Israelites forefathers and the Israelites honored God and made a covenant that they would not be influenced by the gods and traditions of their neighboring cities.

\section{Judges}

Following the death of Joshua the Israelites asked the Lord who should lead them in battle, God sent the men of Judea along with the Simeonites to fight the remaining Canaanites in their region, and they put Jerusalem to the sword and left it in ashes. The generations that followed Joshua did not know God and what he had done for them. The angel of the Lord visited the Israelites and condemned them for following the gods of their neighbors and not destroying their altars. Because 
the nation of Israel disowned the Lord he made their enemies a thorn in their side and they remained under the hand of Jabin, the Canaanite king, until Deborah brought about his end. Gideon carried favor with God and he delivered the Midianites to him which was followed by forty years of peace, but after Gideon passed the Israelites again turned from God. The angel of the Lord appeared again this time to Manoah and his wife promising them that they would have a son, Samson, a Nazirite who is to be set apart for God and will lead the nation. The spirit of God moved with Samson while he led the Israelites during the days of the philistines. No king preceded Samson, the judges watched over the land and the Israelites did as they pleased.

\section{Ruth}

A famine swept through the land while the Judges ruled. Naomi, Elimelech and their two sons were Ephrathites from Bethlehem, Judea. They set out for the country of Moab, after they had arrived and their two sons were married Naomi's husband and both their sons died. Naomi urged Ruth and Orpha, her two daughters-in-law to return to their homes to find new husbands. Orpha returned to her home but Ruth refused to leave Naomi and they returned to Bethlehem. Boaz took favor on Ruth because of her loyalty to Naomi and redeemed the property of Elimelech and Ruth became his wife. Ruth soon gave birth to Obed who became the father of Jesse the father of David.

\section{Samuel}

At the house of the Lord, Hanna wife of Elkanah prayed for a child. The God of Israel heard her voice and granted Hanna with a son she named Samuel. Because her womb was closed before she spoke to the Lord she knew God had blessed her and she gave Samuel to the Lord. Eli was the priest at the Lord's house in Shiloh where the Ark of the Covenant, Samuel worked with him at the temple until one night the Lord called on Samuel and told him that he would soon judge Eli because his sons had sinned with his knowledge. When the Lords word manifested Samuel was attested as a prophet of the Lord and his word was known to all of Israel. Before Eli died the Hebrews battled with the Philistines, they suffered a great loss of foot solders and when the war ended the Ark of the Covenant was captured by their enemies. The Ark of the Covenant was taken by the Philistines through several cities, wherever it traveled death was found in its wake. Unable to bear their losses the Philistines returned the Ark to the Israelites. (Qur'an: Sura 2:248)

The Israelites requested a king to lead them; (Qur'an: Sura 2:246) God spoke to his prophet Samuel and instructed him to adorn Saul from the tribe of Benjamin with the crown. Samuel sent Saul to meet with the prophets in Gibeah where he was made king of Israel and he reigned for forty-two years. After Saul failed the Lord, God ordered Samuel to leave for Bethlehem where he consecrated Jesse and his sons; among them Samuel anointed David and sent him along with his harp to work for Saul.

The Philistines and the Israelites lead by Saul gathered to battle. Among the Philistines was a giant solder clad in bronze, Goliath challenged any Israelite to fight him. David armed with a staff, a sling, five stones and the God of Israel struck down Goliath. (Qur'an: Sura 2:251) The head of Goliath was removed with his own sword and taken to Jerusalem. Saul became jealous of David's 
success in leading the conquests of the Israelites and he plotted to kill David. Twice the Lord delivered Saul into the hand of David but he refused to kill his master the Lords anointed.

The life was taken from the Lords prophet Samuel and he was buried in Ramah. Saul, terrified of the Philistines knew that God no longer fought with them so he sought a medium (spiritist) to raise Samuel from the earth. Samuel told Saul that the Lord has torn the kingdom from him and has handed it to David. When Saul had seen that Israel and his three sons had been slain on Mount Gilboa by the Philistines, he fell on his own sword.

\section{Samuel}

After defeating the Amalekites, David returned to Ziklag where he learned of Saul's death. At the Lords request David and his two wives traveled to Hebron and he was anointed as king of Israel. (Qur'an: Sura 2:251) The House of Saul and the House of David remained at war. King David and his men marched to Jerusalem and defeated the Jebusites and captured the city of Zion. A palace was built for King David and the city was named the city of David, there the king was prosperous and reigned over Israel for thirty three years.

To the sound of harps and trumpets a procession lead the Ark of the Covenant from the house of Abinadab to the city of David where it was placed in a tent that David prepared for it. David felt unworthy of his cedar palace while the Ark of God remained within a tent, and the King expressed his discomfort to the prophet Nathan. The Lord spoke to Nathan and told him that the Lord will establish a house for Israel where they will not be disturbed from there enemies and they will be given rest from war and toil. The Lord told David that he will raise his offspring to succeed him and from his blood will come a king who will build a house for the Lord in Jerusalem.

While the men of Israel were at war David saw Bathsheba the wife of Uriah from his palace, he sent for her a lay with her and she became pregnant. David invited Uriah to his palace to give him a gift he then sent him home to his wife but Uriah refused saying that he would not go home and enjoy his home while the army of David was fighting and living along with the Ark of the Lord in tents. David decided to send Uriah back to war and he placed him on the front line where he knew he would be killed. After Uriah was dead Bathsheba became the wife of David and she had a son. The prophet Nathan then came to David with a parable the lord had revealed to him. It was about the evils of a rich man and the generosity of a poor man, after hearing the parable David enquired who the rich man was, wanting him to pay for what he has done. Nathan told David that he was the rich man. The Lord was displeased with David and his son became ill and died. The Lord forgave David and he and Bathsheba were blessed with another son the prophesized king Solomon.

The Lord delivered David from the hand of Saul and he sang to the Lord:

"The LORD is my rock, my fortress and my deliverer; my God is my rock, in whom I take refuge, my shield and the horn of my salvation. He is my stronghold, my refuge and my savior from violent men you save me.

I call to the LORD, who is worthy of praise, and I am saved from my enemies. The waves of death swirled about me; the torrents of destruction overwhelmed me. 
The cords of the grave coiled around me; the snares of death confronted me.

In my distress I called to the LORD; I called out to my God. From his temple he heard my voice; my cry came to his ears.

The earth trembled and quaked, the foundations of the heavens shook; they trembled because he was angry.

Smoke rose from his nostrils; consuming fire came from his mouth, burning coals blazed out of it. He parted the heavens and came down; dark clouds were under his feet.

He mounted the cherubim and flew; he soared on the wings of the wind.

He made darkness his canopy around him the dark rain clouds of the sky.

Out of the brightness of his presence bolts of lightning blazed forth.

The LORD thundered from heaven; the voice of the Most High resounded.

He shot arrows and scattered the enemies, bolts of lightning and routed them.

The valleys of the sea were exposed and the foundations of the earth laid bare at the rebuke of the LORD, at the blast of breath from his nostrils.

He reached down from on high and took hold of me; he drew me out of deep waters.

He rescued me from my powerful enemy, from my foes, who were too strong for me.

They confronted me in the day of my disaster, but the LORD was my support.

He brought me out into a spacious place; he rescued me because he delighted in me.

The LORD has dealt with me according to my righteousness; according to the cleanness of my hands he has rewarded me.

For I have kept the ways of the LORD; I have not done evil by turning from my God.

All his laws are before me; I have not turned away from his decrees.

I have been blameless before him and have kept myself from $\sin$.

The LORD has rewarded me according to my righteousness, according to my cleanness in his sight.

To the faithful you show yourself faithful, to the blameless you show yourself blameless, to the pure you show yourself pure, but to the crooked you show yourself shrewd.

You save the humble, but your eyes are on the haughty to bring them low.

You are my lamp, O LORD; the LORD turns my darkness into light.

With your help I can advance against a troop; with my God I can scale a wall.

As for God, his way is perfect; the word of the LORD is flawless. He is a shield for all who take refuge in him.

For who is God besides the LORD And who is the Rock except our God?

It is God who arms me with strength and makes my way perfect.

He makes my feet like the feet of a deer; he enables me to stand on the heights.

He trains my hands for battle; my arms can bend a bow of bronze.

You give me your shield of victory; you stoop down to make me great.

You broaden the path beneath me, so that my ankles do not turn.

I pursued my enemies and crushed them; I did not turn back till they were destroyed.

I crushed them completely, and they could not rise; they fell beneath my feet.

You armed me with strength for battle; you made my adversaries bow at my feet.

You made my enemies turn their backs in flight, and I destroyed my foes.

They cried for help, but there was no one to save them to the LORD, but he did not answer.

I beat them as fine as the dust of the earth; I pounded and trampled them like mud in the streets.

You have delivered me from the attacks of my people; you have preserved me as the head of nations. 
People I did not know are subject to me, and foreigners come cringing to me; as soon as they hear me, they obey me.

They all lose heart; they come trembling from their strongholds.

The LORD lives! Praise be to my Rock! Exalted be God, the Rock, my Savior!

$\mathrm{He}$ is the God who avenges me, who puts the nations under me, who sets me free from my enemies.

You exalted me above my foes; from violent men you rescued me.

Therefore I will praise you, O LORD, among the nations; I will sing praises to your name.

He gives his king great victories; he shows unfailing kindness to his anointed, to David and his descendants forever." (2 Samuel 22:2-51)

\section{Kings}

When King David was numbered in years the leadership of the Israelites became contentious. Despite Adonijah's efforts to lure the kingship away from Solomon with great sacrifices of cattle and fattened caves, David placed his son Solomon upon the throne. Solomon was anointed by Zadok the priest with oil from the sacred tent. Not long after the city of David was bequeathed to King Solomon, David died.

The wall that would surround Jerusalem and enclosed Solomon's palace and the temple of God was not yet complete when an alliance was made between King Solomon and pharaoh the king of Egypt. Solomon took the pharaoh's daughter for his wife and they returned to Jerusalem where they sacrificed burnt offerings on the high altar at Gibeon. The Lord spoke to Solomon in a dream and asked him what he wanted; Solomon asked God if he would give his servant a discerning heart to govern his people and decipher right from wrong. God was pleased that Solomon did not ask for long life or riches so God granted him all he asked for and all that he did not, God told him that he will be blessed with a long life and he will see splendor beyond all other kings.

The Lord had granted peace on all sides of the Israelites, and just as the prophet Nathan had told King David his son Solomon began building a house for the Lord in Jerusalem. An army of stone masons cut the foundations of the temple as cedars from Lebanon were floated down by sea. The temple's blueprint was reveled to Solomon and for seven years he built the sanctuary as God requested. Solomon also built for himself a palace and a courthouse where he could judge. When the temple was complete and all the furniture and lamp stands had been made Solomon summoned the elders of Israel and the leaders of the twelve tribes to bring the Ark of the Covenant from Zion the city of David to Jerusalem. The priests and the levities rested the Ark in the most holy place beneath the wings of the cherubim which inhabited the inner sanctuary. When the two stone tablets that Moses had placed in the Ark reached their resting place a dark cloud formed over the temple and the glory of the Lord filled the sanctuary.

Several ships were built and sent from the Red Sea to trade with other nations, the ships returned with gold, silver and exotic animals. During the reign of King Solomon the kingdom had never seen such splendor. However, the many foreign wives Solomon took for himself soon lead him astray and the Lord became angry with him when he built altars for the gods of his wives. Before Solomon fell to the earth the Lord told the King that he will tear the kingdom from his son Rehoboam's hand 
and give ten tribes to Jeroboam. Only the tribe of Judah will remain in Jerusalem with Rehoboam and the house of David.

King Jeroboam did not reign long before his sin angered the Lord and the house of Jeroboam fought with the Rehoboam king of Judah. Jeroboam was succeeded by King Nadab, King Baasha, King Elah, King Zimri, King Omri and King Ahab and Israel remained at war with Judah through the reign of King Asa. The Israelites became corrupted and began worshiping the god Baal, the prophet Elijah commanded the prophets of Baal to slaughter a bull but leave the sacrifice unlit Elijah did the same and they both called upon their gods to light the sacrifices. The prophets of Baal called on their god but no fire came to the bull, then Elijah called the God of Abraham and the bull became engrossed in flame.

\section{Kings}

The Lord sent Elijah to Jericho, Elisha went with him knowing that the Lord was going to take Elijah. When they reached the Jordan River Elijah struck the water with his cloak and the waters divided to reveal dry ground. They crossed the river and before Elijah was taken to heaven by a chariot of fire the spirit of Elijah fell upon Elisha. The prophet Elisha fed the hungry healed the lepers and raised the dead in the name of the Lord.

The prophet Elisha sent a man from the company of the prophets to Ramoth Gilead to anoint Jehu son of Jehoshaphat as the king of Israel. Jehu deceived the ministers of Baal and summoned them for a great sacrifice to Baal, when all the ministers where in the temple of Baal Jehu destroyed the temple, the ministers were slain and the sacred stone was burned to ashes.

Joash became king in Jerusalem and he ordered the prophets to collect the money that was given as offering and use it to repair the temple. Twenty three years after Joash had made his requested the priests had not yet restored the temple. Joash collected the offerings and paid the workers while they restored the temple to good repair. Following the death of the prophet Elisha and his father King Joash, Amaziah became King of Judah. King Amaziah called Jehoash King of Israel to meet him in battle, Jehoash warned Amaziah that he would defeat him and it was so. King Amaziah was captured in Beth Shemesh and the wall surrounding Jerusalem fell and King Amaziah emptied the gold and silver from the temple of the Lord.

The Lord became upset with the Israelites because they followed worthless idols and they were removed from his presences, Judah had also forgotten God and they were torn from Jerusalem into exile in Assyria.

Josiah had succeeded his father Uzza as king of Judah when the Book of the Law was found in the Lords temple during its restoration. Josiah summoned the prophets, priests and the people of Judah to the temple of the Lord and he renewed the covenant with God. The high priest Hilkiah and the doorkeepers of the temple were commanded to remove the articles made for Baal in the Lords house; they were take outside and burned as were all the high altars. Pagan priests throughout the land were slain and when King Josiah returned to Jerusalem for the Passover. 
During the reign of Zedekiah Nebuchadnezzar King of Babylon waged war on Jerusalem and besieged the city. The King's escape attempt failed and he was captured and taken to Babylon. The imperial guard of Nebuchadnezzar entered Jerusalem and set fire to the temple of the Lord and all that remained of the city. The bronze pillars and all the gold and silver that adorned the temple were taken to Babylon.

\section{Chronicles}

The book of 1 Chronicles records the genealogy of Israel from Adam through to King Solomon. Adam, Seth, Enosh, Kenan, Methuselah, Lamech and Noah are followed by: the sons of Noah, the Japhethites, the Hamites, the Semites, the family of Abraham, the descendents of Hagar, the descendents of Keturah, the descendents of Sarah, the sons of Esau, the kings and people of Edom, the sons of Israel (Reuben, Simeon, Levi, Judah, Issachar, Zebulun, Dan, Joseph, Benjamin, Naphtali, Gad, and Asher), the sons and kings of Judah, the sons of David, the descendents of Simeon, the sons of Reuben, the Gadites, the sons of Levi, the sons of Issachar, the sons of Benjamin, the sons of Naphtali, the descendents of Manasseh, the descendents of Ephraim, the sons of Asher and the descendents of Saul.

Saul and his sons fell to the ground on mount Gilboa after a bitter war with the Philistines, his armor and head was hung in the temple of Dagon and the remaining Israelites where buried under the great tree in Jabesh. Saul's unfaithfulness to the lord resulted in his death and the kingdom was bestowed upon David. Jerusalem (Jebus) at that time was held by the Jebusites, the fortress of Zion soon fell to David's hand and the city of David was created to rule over the land God promised to the Israelites. Under Saul's reign the Ark of the Covenant remained in the house of Abinadab in Baalah, Judah. David assembled the Israelites and they setout for Baalah with a new cart to carry the Ark of the Covenant to the house of Obed-Edom where it remained until David prepared a tent for the ark in Jerusalem. Fine linen covered David and the Levites and the streets were filled with song as the ark was carried as Moses had instructed to the city of David. Set to the background of sacrificed ram and burnt offerings David gave praise to the Lord (1 Chronicles 16:736).

After a palace of cedar was built for the anointed king David he asked the prophet Nathan why he should dwell in a palace while the Ark of the Covenant resided in a tent. The Lord told David that the house of the Lord will be made from his blood but he will not be the one to build it, that honor will be bestowed upon David's son Solomon who will build a kingdom of splendor never before seen.

The angel of the Lord stood between heaven and earth with a sword drawn above Jerusalem, the angel reaped 70,000 men for the sin David had committed by counting his armed men. David built an altar on the threshing floor of Araunah and the angel placed his sword back in its sheath. When David's days became numbered preparations began to build the temple of the Lord, the King charged his son Solomon with the task and provided him with cut stone, wood, gold, silver and bronze beyond measure and craftsmen beyond number. The Lord provided peace on all sides of the Israelites while the House of the Lord was built according to his plan. The duty of Levites along with the descendents of Aaron was to serve in the House of the Lord and keep its gates. They 
oversaw the courtyard and the side rooms, they purified all that was sacred and gave praise to the Lord morning and night.

\section{Chronicles}

At the high place in Gibeon, Solomon and the whole assembly of Israelites sacrificed a thousand burnt offerings on the bronze altar of the tent of meeting. In the night God appeared to Solomon and asked him what he desired from the Lord. Solomon asked the Lord to provide him with wisdom and knowledge to guide God's people and judge them fairly. God was pleased with Solomon's humble request and provided him with wisdom along with wealth, riches and honor beyond imagination. During the reign of King Solomon the temple of the Lord was built along with great palaces and law courts, and silver was more abundant than stone in the city of David.

The temple furniture was build of gold and the sanctuary of the temple was lined with cherubim standing guard over the Ark of the Covenant which the Levite priests placed within the inner chamber. The sound of trumpets and song filled the temple and the Lord covered Zion with a dark cloud. After blessing the people King Solomon knelt before the Israelites raised his hands to heaven and said: "O Lord, God of Israel, there is no God like you in heaven of on earth-you who keep your covenant of love with your servants who continue wholeheartedly in your way... Now arise, $\mathrm{O}$ Lord God, and come into your resting place, you and the ark of your might" (2 Chronicles $6: 14-41)$. Following the dedication of the temple fire rained from heaven on the burnt offerings and the glory of the Lord filled the sanctuary as the Israelites chanted "He is good; his love endures forever." (2 Chronicles 7:3)

Following the death of Solomon and his burial in the city of David, Rehoboam succeeded his father as King. Jeroboam and the Israelites rebelled against the King; they rejected the Levites and named their own priests as their pagan neighbors did. King Abijah who succeeded Rehoboam urged the Israelites not to fall away from the Lord but Israel did not listen and God's people were divided into two kingdoms. Those who resided in Jerusalem and the region of Judah were lead by King Abijah, while the remaining followed Jeroboam son of Nebat until the Lord struck him down.

Asa became king of Judah after Abijah and he followed the Lord and destroyed the high places of the foreign gods, fortified the cities and armed his men to defend Judah. Numerous kings rose and fell while a bitter divide remained between Israel and Judah. The kings were unfaithful and had forgotten the Lord and his commands. Ahaz King of Judah defiled the temple of the Lord and made altars for foreign god all around Judah. During the reign of King Hezekiah the doors of the temple were opened, the priests and the Levites returned to repair and purify the Lords house for the Passover. The Passover lamb was sacrificed along with a thousand bulls and seven thousand sheep King Hezekiah provided for the festival unparalleled in Jerusalem since the days of Solomon. Manasseh the son of Hezekiah became king following Hezekiah's death, he did evil in the eyes of the Lord and lead the people of Israel astray. Manasseh built an altar to Baal which displeased the Lord and he was soon taken prisoner by the Assyrians. While imprisoned in Babylon Manasseh prayed to the Lord and was humbled, he returned to Jerusalem to erase all the evil he had done. After King Amon did much to anger the Lord his son King Josiah assembled workers to restore the temple. During the reconstruction the Book of the Law that had been given to Moses was found and the Passover sacrifice was performed as Moses was commanded. 
However during the reign of Jehoiakim, Nebuchadnezzar king of Babylon attacked the temple of the Lord and captured king's Jehoiakim and Jehoiachin, and he returned to Babylon with numerous articles from the temple. The fall of Jerusalem came at the hand of Nebuchadnezzar under the rule of Zedekiah, the wall was destroyed and temple was burned. Cyrus king of Persia fulfilled the prophecy of Jeremiah when he was handed the kingdoms of the earth and appointed to build a temple for God in Jerusalem.

\section{Ezra}

Cyrus king of Persia had inherited the kingdoms of the earth and was appointed by the Lord to fulfill the prophecy of Jeremiah and build a temple in Jerusalem. Cyrus requested captives from the nation of Israel to return to Judah and rebuild the Lord's house. Before the Israelites departed for Zion Cyrus removed the silver and gold that Nebuchadnezzar placed in the temple of his god and returned it to them. When the Israelites arrived in Jerusalem, Jeshua and his fellow priests rebuilt the altar and resumed the morning and evening sacrifices. Two years after the Israelites returned from exile Jeshua and the priests appointed the Levites to oversee the reconstruction of the temple. Trumpets blasted and the workers sang as the foundation of the temple was laid. Several of the older priests and Levites wept as the foundation was made; fore they had seen the glory of the former temple. Despite Tattenai the governor of Trans-Euphrates attempts to deter the construction the temple, it was completed and dedicated with great sacrifices to God.

Ezra the priest and son of Seraiah arrived in Jerusalem from Babylon. Well versed in the Law, Ezra dedicated himself to the Lord and God placed his hand upon him. It was during this time that Israelite men began marrying women from Israel's neighboring nations. Ezra prayed to the Lord for the forgiveness of the Israelites sins and all those who had married foreign wives confessed.

\section{Nehemiah}

While in the citadel of Susa, Hanani the brother of Nehemiah returned from Judah. Nehemiah asked his brother what remained of Zion. Hanani informed him that the gates of Jerusalem have been burned and the perimeter wall has fallen leaving the survivors in danger. When King Artaxerxes saw that Nehemiah was distressed over the state of the Jewish city he sent Nehemiah to rebuild Jerusalem. Eliashib the high priest along with the other priests went to work repairing the sheep gate, and one section of wall at a time the Israelites rebuilt the entire city. Sanballat and the army of Samaria became angered that the Jews were rebuilding the wall. Fearing an attack the Jews fortified the wall and armed the builders with arrows. Nehemiah prayed for God's protection while they remade Zion. Once the gates were installed the gatekeepers and the Levites took their places and were ordered by Nehemiah not to open them until the sun became hot.

Ezra, the priest, stood in the square before the water gate and read the Book of the Law to all who could understand. The Israelites learned of the life the Lord wanted them to live and they obeyed his command. Wearing sac cloth and dust on their heads on the twenty-fourth day of the month the Israelites gathered to confess their sins and worshiped the Lord. Nehemiah praised God and informed him that his people were slaves in the land he provided for them, and then he made an agreement with God. Nehemiah and the Israelites promised to follow the laws of Moses, respect 
the Sabbath, refrain from giving the neighbors their daughters and rest their land every seven years when they forgive all loans. They promised the Levites they would not be forgotten and nor will the house of our God.

The Levites purified themselves and then the people before they dedicated the wall of Jerusalem with a procession, sacrifices and song. Following the dedication, Nehemiah returned to Artaxerxes the king of Babylon. Upon his arrival back in Jerusalem Nehemiah observed several things that disappointed him, wine presses were worked on the Sabbath and the daughters of Israel were given to foreigners. Nehemiah disciplined the nobles and locked gates to prevent trade on the holy day; he prayed that God would not punish the people for their sins.

\section{Esther}

From the royal throne in the citadel of Susa King Xerxes ruled over 127 provinces, the wealth of his nation was immeasurable. Queen Vashti had defied the king during a great banquet the king held for the nobles and his officials. As a result of the queens refusal to see the king she was removed from the throne and a campaign was undertook to replace her. Among the numerous young virgins who were brought to the kings palace was a Jewish girl named Esther. The sight of Esther overwhelmed the king and he took her as his queen without knowledge of whom she was a descendant of. Following the banquet which honored the newly enthroned queen, Haman son of Hammedatha was granted a seat higher then all other nobles. Mordecai the Jewish man who brought Esther to the king refused to kneel down to Haman which angered him profusely. Once Haman discovered Mordecai was Jewish he set out to destroy the Jewish people.

Haman ordered gallows to be built and he planned to hang Mordecai. However, king Xerxes learned that Mordecai had exposed a plot to assonate the king and he chose to clad the Jew with a royal robe and set him on a horse that the king had ridden while he was paraded through Susa. King Xerxes loved Esther and he granted her a request, when Esther responded she asked the king to spare her life and that of her people. The king granted Esther her request and when he was informed of the gallows Haman had built to kill Mordecai, the king had Haman hung on his own gallows and his estate was given to Queen Esther.

Mordecai became a prominent man in the citadel and the enemies of the Jews where held to the sword, thousands were killed. The Jews sorrow turned to joy and they remember the relief that was granted to them on the fourteenth and fifteenth day of the month of Adar.

\section{Job}

The fear of God was in the heart of Job and he was faithful. Uz the land where Job resided was blessed and Job had acquired a wealth of animals. The Lord loved Job and when Satan spoke evil of him and said that he would disown the Lord if his inheritance were taken, the Lord had faith in Job and allowed Satan to destroy all that he had been blessed with. During the feast several messengers returned to Job and told him that his donkeys and oxen were taken by the Sabeans and his camels by the Chaldeans, his servants were put to the sword and fire from the heavens fell and burned all of his sheep. The last messenger informed Job that a violent storm tore down the 
house of his children and left them all dead. Upon receiving this news Job fell to the ground and said: Naked I came from my mother's womb and naked I will depart. The Lord gave and the Lord has taken away; may the name of the Lord be praised." (Job 1:21-22) Job refused to blame the Lord for his misfortune. Afterwards Satan struck Jobs body with disease and the misery of Job was immeasurable but again Job would not condemn the Lord. Job longed for death and the shelter that the ground provided, his pain consumed every woken moment and he loathed is life for it contained not a drop of meaning; his body was an inescapable prison in which God held the only key. Job questioned if he had become a burden to the Lord.

Bildad the Shuhite, Zophar the Naamathite, Eliphaz the Temanite responded to Job with parables and assured Job a blameless man would not be punished and the Lord had not forgotten him.

Job was righteous in his own eyes so the three men refrained from writing to him. Elihu was disappointed with Bildad the Shuhite, Zophar the Naamathite, Eliphaz the Temanite for allowing Job to justify himself to the Lord and accusing the Lord of ignoring man. Job listened to Elihu when he said that God is greater then man and he does not pervert justice, he loves man and speaks in their ears while they sleep. The Lord God redeems mans soul from the pit and grants him new flesh unconditionally. Repent.

Then God answered Job from the storm and asked: "Who is this that darkens my council with words without knowledge? Brace yourself like a man and I will question you... Where were you when I laid the earth's foundations? Tell me, if you understand. Who marked off its dimensions? ...on what were its footings set? ... Tell me if you know all this. What is the way to the abode of the light? And where does darkness reside? ...What is the way to the place where lightning is dispersed...Does the rain have a father? Who can tip over the water jars of the heavens." (Job 38:2-41)

Job replied to the Lord and repented in dust and ashes, he prayed for his friends and the Lord blessed Job.

\section{Psalms}

The Book of Psalms is a compellation of the poetry written by King David, King Solomon, the sons of Korah and a number of others.

Psalm 1

Blessed is the man who does not walk in the counsel of the wicked or stand in the way that sinners take or sit in the company of mockers, but who delight in the law of the Lord and meditate on his law day and night. They are like a tree planted by streams of water, which yields its fruit in season and whose leaf does not wither-whatever they do prospers. Not so the wicked! They are like chaff that the wind blows away. Therefore the wicked will not stand in the judgment, nor sinners in the assembly of the righteous. For the LORD watches over the way of the righteous, but the way of the wicked will be destroyed. (Psalm 1:1-12)

Psalm 23 
A psalm of King David

The Lord is my shepherd, I Shall not want. He makes me lie down in green pastures, he leads me beside still waters, he refreshes my soul. He guides me along the paths of righteousness for his name's sake. Even though I walk through the valley of the shadow of death, I will fear no evil, for you are with me; your rod and your staff, they comfort me. You prepare a table before me in the presence of my enemies. You anoint my head with oil; my cup overflows. Surely your goodness and love will follow me all the days of my life, and I will dwell in the house of the Lord forever. (Psalm 23:1-6)

Psalm 127

A psalm of King Solomon

Unless the Lord builds the house, the builders labor in vain. Unless the Lord watches over the city, the guards stand watch in vain. In vain you rise early and stay up late, toiling for food to eat-for he grants sleep to those he loves. Children are a heritage from the LORD, offspring a reward from him. Like arrows in the hands of a warrior are children born in one's youth. Blessed is the man whose quiver is full of them. They will not be put to shame when they contend with their opponents in court. (Psalm 127:1-5)

\section{Proverbs}

The proverbs of King Solomon:

"The fear of the Lord is the beginning of knowledge, but fools despise wisdom and discipline." (Proverbs 1:7)

"Wisdom will save you from the ways of wicked men, from men whose words are perverse, who leave the straight paths to walk in dark ways" (Proverbs 2:12-13)

"A gentle answer turns away wrath, but a harsh word stirs up anger. The tongue of the wise adorns knowledge, but the mouth of the fool gushes folly. The eyes of the LORD are everywhere, keeping watch on the wicked and the good. The soothing tongue is a tree of life, but a perverse tongue crushes the spirit. A fool spurns a parent's discipline, but whoever heeds correction shows prudence. The house of the righteous contains great treasure, but the income of the wicked brings ruin. The lips of the wise spread knowledge, but the hearts of fools are not upright. The LORD detests the sacrifice of the wicked, but the prayer of the upright pleases him. The LORD detests the way of the wicked, but he loves those who pursue righteousness." (Proverbs 15:1-9)

"It is the glory of God to conceal a matter; to search out a matter is the glory of kings. As the heavens are high and the earth is deep, so the hearts of kings are unsearchable. Remove the dross from the silver, and a silversmith can produce a vessel; remove wicked officials from the king's presence, and his throne will be established through righteousness. Do not exalt yourself in the king's presence, and do not claim a place among his great men; it is better for him to say to you, "Come up here," than for him to humiliate you before his nobles. (Proverbs 25:1-7) 
The proverbs of Agur:

"I am weary, God, but I can prevail. Surely I am only a brute, not a man; I do not have human understanding. I have not learned wisdom, nor have I attained to the knowledge of the Holy One. Who has gone up to heaven and come down? Whose hands have gathered up the wind? Who has wrapped up the waters in a cloak? Who has established all the ends of the earth? What is his name, and what is the name of his son? Surely you know! Every word of God is flawless; he is a shield to those who take refuge in him." (Proverbs 30:1-5)

\section{Ecclesiastes}

Words from the son of David, king of Israel: "Meaningless! Meaningless! says the Teacher. Utterly meaningless! Everything is meaningless." (Ecclesiastes 1:2)

The son of David discusses the meaning of life and our toils under the sun: "All streams flow into the sea, yet the sea is never full." (Ecclesiastes 1:7) The enigmas of the earth can not be solved without God; the Lord God is our meaning. Earthly pleasure accomplishes little nothing can be gained under the sun. Toilsome labor ends in nothing, meaningless as chasing after the wind. There is a time for all things under heaven, when I looked at the oppression under the sun, the living should not be envious of the dead.

Enter the house of God to listen rather then to sacrifice like the fools who know not that they sin. The day of death is better then the day of feast, for death belongs to us all and the laughter of fools is meaningless.

An eternal home exists and life is but a few meaningless days, remember the Lord and obey his commandments for the Lord sees every hidden good and evil.

\section{Song of Songs (Solomon)}

The book of Song of Songs (also referred to as 'Song of Solomon') contains a collection of love poetry from the house of King Solomon.

"I looked for the one my heart loves; I looked for him but did not find him. I will get up now and go about the city, through its streets and squares; I will search for the one my heart loves. So I looked for him but did not find him. The watchmen found me as they made their rounds in the city. 'Have you seen the one my heart loves?' Scarcely had I passed them when I found the one my heart loves. I held him and would not let him go till I had brought him to my mother's house, to the room of the one who conceived me. Daughters of Jerusalem, I charge you by the gazelles and by the does of the field: Do not arouse or awaken love until it so desires. Who is this coming up from the wilderness like a column of smoke, perfumed with myrrh and incense made from all the spices of the merchant? Look! It is Solomon's carriage, escorted by sixty warriors, the noblest of Israel, all of them wearing the sword, all experienced in battle, each with his sword at his side, prepared for the terrors of the night. King Solomon made for himself the carriage; he made it of wood from 
Lebanon. Its posts he made of silver, its base of gold. Its seat was upholstered with purple, its interior inlaid with love. Daughters of Jerusalem, come out, and look, you daughters of Zion. Look on King Solomon wearing a crown, the crown with which his mother crowned him on the day of his wedding, the day his heart rejoiced. (Song of Songs 3:1-11)

\section{Isaiah}

The Book of Isaiah records the vision of Jerusalem and Judah God revealed to the prophet Isaiah son of Amoz under the reign of Kings Uzziah, Jotham, Ahaz, and Hezekiah.

The earth listened as the Lord spoke through his prophet Isaiah. The Lord reared children but they have rebelled and forsaken their God like those at Sodom and Gomorrah. The Lord took no pleasure in their sacrifices and requested that when the people appear to him they shall bring with them no meaningless offerings and burn no incense. The appointed feasts displeased the Lord and they were forbidden. The Jews hands were covered in blood and when they lifted them up to the Lord he would not listen, the Lord instructed the people to seek justice and defend the fatherless and when they see the oppressed, encourage them.

The Lord warned the house of Jacob of the last days when the temple of the Lord will triumph over all other, the Word of the Lord will set forth from Zion and God will judge over all the nations. Jerusalem will fall to chaos and the warriors will fall to the sword, only the gates of Zion will be left to lament.

The Lord reveled to Judah a parable of the vineyard. The Lord God made a vineyard on a fertile hillside; he cleared the soil of stones and built a watchtower to guard over it. The Lord searched the vineyard for good grapes but it produced none. After the love the Lord had shown the vineyard it bore him no desirable fruit. The Lord commanded the house of Israel to judge between the Lord and his vineyard and asked what more could the Lord have done for the vineyard? God then revealed that the vineyard of God was the house of Israel and the Almighty searched for righteousness but found only bloodshed.

Following the death of King Uzziah Isaiah saw the robe of the Lord fill the temple; He was seated on a throne high above. Flying around the Almighty were seraphs with wings that covered their eyes and feet, and they called to one another: "Holy, holy, holy, is the Lord God Almighty; the whole earth is filled with his glory." (Isaiah 6:3) Their voices filled the temple with smoke and its thresholds trembled. Isaiah, an unclean man, had seen the Lord God. A seraph gathered a burning coal from the altar and touched Isaiah's lips to atone for his wrongs. The Lord sent Isaiah out until the land was forsaken and the cities found themselves in ruin to be: "...ever hearing, but never understanding; be ever seeing, but never perceiving." (Isaiah 6:9)

The Lord revealed through the prophet Isaiah that there shall be no more distress in Galilee from the Gentiles; those who walked in darkness will see a great light. A son will be given and he will be called "Wonderful Counselor, Mighty God, Everlasting Father, Prince of Peace."(Isaiah 9:6) His government of peace will have no end and he will reign over David's throne. "Here is my servant, whom I uphold, my chosen in whom I delight; I will put my spirit on him and he will bring justice to all nations" (Isaiah 42:1) 
Jeremiah

The word of the Lord was given to Jeremiah the priest at Anathoth and son of Hilkiah, while the house of Israel went into exile during the reign of King Josiah and his son King Zedekiah.

Faithless Israel has committed adultery on the high hill, and with wood and stones her unfaithful sister Judah has also become immoral. After a certificate of divorce had been delivered, the Lord called Israel to return to Zion. Circumcise your hearts and rid your selves of detestable idols, the Lord requested, and he promised to save them, for Jeremiah had warned a dark cloud was on its way.

A thunderstorm of armed chariots departed from the hills of Ephraim. Trumpets screamed as the battle surrounded the city of Jerusalem which stood fearfully to the backdrop of a ruined Judah. After the Lord searched the streets of the city and found not one honest man the sickle fell upon the daughter of Zion and not a stone remained in place. And the Israelites were scattered among lands not their own.

The prophet Jeremiah foretold the Israelites that their home will become a desolate wasteland, and they will be enslaved by Nebuchadnezzar for seventy years until the cup filled with God's wrath is drank by the kings of all the lands holding the Israelites. While confined in the courtyard of the guards the Lord told Jeremiah that the house of Judah and the house of Israel will be taken out of captivity and return to Zion where they will restore the throne of King David.

\section{Lamentations}

Funeral poetry for the dead city of Jerusalem

"How deserted lies the city, once so full of people! How like a widow is she, who once was great among the nations! She who was queen among the provinces has now become a slave. Bitterly she weeps at night, tears are on her cheeks. Among all her lovers there is none to comfort her. All her friends have betrayed her; they have become her enemies. After affliction and harsh labor, Judah has gone into exile. She dwells among the nations; she finds no resting place. All who pursue her have overtaken her in the midst of her distress. The roads to Zion mourn, for no one comes to her appointed festivals. All her gateways are desolate, her priests groan, her young women grieve, and she is in bitter anguish. Her foes have become her masters; her enemies are at ease. The LORD has brought her grief because of her many sins. Her children have gone into exile, captive before the foe. All the splendor has departed from Daughter Zion. Her princes are like deer that find no pasture; in weakness they have fled before the pursuer. In the days of her affliction and wandering Jerusalem remembers all the treasures that were hers in days of old. When her people fell into enemy hands, there was no one to help her. Her enemies looked at her and laughed at her destruction. Jerusalem has sinned greatly and so has become unclean. All who honored her despise her, for they have seen her nakedness; she herself groans and turns away. Her filthiness clung to her skirts; she did not consider her future. Her fall was astounding; there was none to comfort her. 'Look, LORD, on my affliction, for the enemy has triumphed.' The enemy 
laid hands on all her treasures; she saw pagan nations enter her sanctuary- those you had forbidden to enter your assembly.

All her people groan as they search for bread; they barter their treasures for food to keep themselves alive. 'Look, LORD, and consider, for I am despised.' is it nothing to you, all you who pass by? Look around and see. Is any suffering like my suffering that was inflicted on me, that the LORD brought on me in the day of his fierce anger? 'From on high he sent fire, sent it down into my bones. He spread a net for my feet and turned me back. He made me desolate, faint all the day long. 'My sins have been bound into a yoke; by his hands they were woven together. They have been hung on my neck, and the Lord has sapped my strength. He has given me into the hands of those I cannot withstand. 'The Lord has rejected all the warriors in my midst; he has summoned an army against me to crush my young men. In his winepress the Lord has trampled the Virgin Daughter Judah. 'This is why I weep and my eyes overflow with tears. No one is near to comfort me, no one to restore my spirit. My children are destitute because the enemy has prevailed.' Zion stretches out her hands, but there is no one to comfort her. The LORD has decreed for Jacob that his neighbors become his foes; Jerusalem has become an unclean thing among them. 'The LORD is righteous, yet I rebelled against his command. Listen, all you peoples; look on my suffering. My young men and young women have gone into exile. 'I called to my allies but they betrayed me. My priests and my elders perished in the city while they searched for food to keep themselves alive. 'See, LORD, how distressed I am! I am in torment within, and in my heart I am disturbed, for I have been most rebellious. Outside, the sword bereaves; inside, there is only death. 'People have heard my groaning, but there is no one to comfort me. All my enemies have heard of my distress; they rejoice at what you have done. May you bring the day you have announced so they may become like me. "Let all their wickedness come before you; deal with them as you have dealt with me because of all my sins. My groans are many and my heart is faint." (Lamentations 1:1-22)

\section{Ezekiel}

While in exile the heavens opened to the prophet Ezekiel and revealed a vision of God.

Fire danced between the four winged creatures that emerged from a hole in the clouds. Each adorned with four heads one appeared as a man's while the others looked like an ox's, a lion's and an eagle's. They followed the spirit back and forth like lightning. Intersecting wheels which could move in any direction resided beside the four faced creature and their rims were covered with eyes. Their wings fell to the ground at the sight of a throne covered with sapphires. A figure glowing like burning metal rested upon the throne, and a voice resonated through the clouds. The spirit of the Lord lifted Ezekiel from the ground and set him to the house of Israel to teach the nation that has rebelled against their creator. A scroll was rolled out before the prophet; on it were words of lament. Ezekiel consumed the scroll as the lord instructed.

Ezekiel was among the exiles in Tel Abib for seven days when the Lord appeared to him in the plains. The Lord commanded Ezekiel to draw on a clay tablet the city of Jerusalem complete with battle plans to besiege the city. The end is near for the exiled Israelites that have forsaken the Lord, they will fall to the sword, famine and plague in front of their idols, and they will know the Lord when vengeance is laid upon them. 
When enemy nations have seen Israel in exile and punished for their sin, the Lord will have compassion on the house of Jacob and the Lord will no longer hide his face. The Lord took Ezekiel to a high mountain where he placed an image of the temple along with its dimensions in the imagination of the prophet. The man who lead Ezekiel through the vision and measured its plan took him to the gate that faced east where he could see the Glory of the Lord entering the temple from were he spoke to Ezekiel. The Lord told the prophet that the house of Israel will never again defile Gods name and if the Israelites will put away their worthless idols the design of the temple is to be revealed to them. The temples arrangement and regulations are to be followed, the Levites shall serve in the Lords house and God will dwell among the Israelites again.

Water flowed east from the threshold of the temple, a man lead Ezekiel through the river which ended in the sea. Life blossomed from the river because it was not bitter with salt and the river marked the boundary where the land was divided among nations.

\section{Daniel}

After Nebuchadnezzar had laid siege to Jerusalem under the reign of king Jehoiakim, the king and articles from the temple were taken to Babylon and installed in the temple of his god. From among the royal family of Israel and the nobility the finest were chosen by Nebuchadnezzar and taught the language and literature of Babylonia. The men were then asked to serve the king in his royal palace; among them were Daniel, Hananiah, Mishael and Azariah from Judah. The Judeans were renamed Belteshazzar, Sandrach, Meshach and Abednego, the men were knowledgeable and wise but the king found no parallel to Daniel.

Nebuchadnezzar had a dream that troubled him and he called upon his servants to interpret it for him, none of the wise men could answer the king so he had them executed. Before Arioch, commander of the king's guard captured Daniel, he prayed to the Lord. Daniel was taken to the king and told him that his dream was a vision of tomorrow from the God of Israel. King Nebuchadnezzar thanked Daniel by placing him, Sandrach, Meshach and Abednego above all the wise men of Babylon.

An enormous image Nebuchadnezzar constructed of gold for the people to worship was revealed to the song of flutes and trumpets. The king became outraged when he heard that Sandrach, Meshach and Abednego refused to honor the image and ordered his solders to throw them into the furnace. The men remained faithful and the fire did not harm them because the angel of God was a shield.

King Belshazzar, son of Nebuchadnezzar, sent for Daniel to translate mysterious writing that appeared on his wall. That night the king was slain. King Darius who was in favor Daniel was forced to place him in a den of lions because he worshiped the Lord, but God saved Daniel from their wrath.

During the reign King Belshazzar a dream fell upon Daniel. The four winds of heaven turned the sea as it opened to reveal four winged beasts from under its surface. Three of the beasts were similar; although they appeared different from one another they were distinct from the fourth beast 
which had ten horns and large iron teeth. Among the ten horns was a smaller horn with human eyes and upon them was a throne which held the ancient of days who was wrapped in white and a river of fire flowed from him. The clouds were torn and the son of man descended to the ancient of days, all nations worshiped him and his kingdom is everlasting. Daniel asked one who resided within the dream to interpret the image and the man said the four great beasts were kingdoms raised on earth. The horned beast is also a kingdom and the ten horns are its kings, after they have fallen to become earth a king will arrive who will upset the nation and its saints. The Kings throne will be taken by the courts and the kingdom will be handed over to the saints.

\section{Hosea}

The Word of the Lord was given to Hosea son of Beeri, during the reign of Judean kings Uzziah, Jotham, Ahaz and Hezekiah, and Jeroboam king of Israel.

The Lord told Hosea to take for him an adulterous wife and disobedient children for the people of Israel have defiled their fathers name and worshiped sticks, because of this they will be punished. Your wife will forget you and commit horrible acts against you but you will not disown her when she returns. The Lord will also save his people, not by sword but by the Lords grace, God requires not sacrifice and blood to atone for the sin of Israel but mercy and acknowledgment. In the day of Jezreel, Judah and Israel shall reunite and from the land will come one leader. Repentance is the path to the Lord and his blessings.

\section{Joel}

The Lord revealed the Word of God to Joel son of Pethuel.

A kingdom has entered the land with the fangs of a lion and laid to ruin the vines, morn like one in sackcloth Israel for the harvest has been burned. Summon the priests and elders to the Lords house and cry for forgiveness. Dark clouds are within sight and the day of the Lord is near, sound the trumpet in Zion the army is approaching. The moon has lost its light and the stars hide from the Lord who rides ahead of the warriors. The request of their hearts has been made, if fulfilled the grace of God will embrace the nation. The Lord is compassionate; he will rain on the people and the threshing floors will be covered with grain. When Judah and Jerusalem are restored all nations will be taken to the valley of Jehoshaphat and they will be judged for their actions against my people Israel. When the earth trembles and the stars no longer shine the Lord will be a refuge for the Israelites, and they will know that God dwells in Zion.

\section{Amos}

Two years before the earthquake the land under the reign of Uzziah, king of Judah and Jeroboam, king of Israel the Lord gave words to the shepherd Amos.

Fire will be sent upon the walls of Gaza and the gate of Damascus shall fall for the sin they have committed. The house of Hazael will burn along with the fortress of Ben-Hadad, and those who are 
crowned in Aven and Beth Edan will be slain. The king of Ashdod, Ekron and the Philistines along with Tyre will receive no mercy from the Lord. Edom, Teman, Ammon, Moab, and the walls of Rabbah will all submit to the flame. When judgment falls upon Judah and Israel warriors and horsemen will flee for their lives and the horns on the altar of Bethel will be cut off.

The Lord told the Israelites through Amos to seek the Lord and they will live. Righteousness will weight more then burnt offerings on the day of the Lord when the dark cloud covers the light. Israel will not be able to hide in its grave from God, but he who builds his palace in heaven and sets its foundations on the earth is the Lord.

Before it accepts annihilation the fallen tent of David will be restored by the Lord and it will again bare the name of the Lord God of Israel.

\section{Obadiah}

The word of the Lord as it was given to Obadiah.

For all nations the day of the Lord is near and your deeds will be returned to you. On Mount Zion there will be deliverance and the house of Jacob will receive its inheritance.

\section{Jonah}

The Lord commanded Jonah to travel the city of Nineveh and preach against it, but Jonah attempted to hide from the Lord and he set sail for Tarshish where he was greeted with a violent sea. The sailors asked Jonah what they should do and Jonah told them to throw him overboard and the seas would calm. When Jonah was submerged in the water a great fish swallowed him and he remained inside for three days. While engulfed within the fish Jonah prayed; the Lord answered Jonah and the fish spit him onto dry land.

Again the Lord commanded Jonah to travel the city of Nineveh to inform them that their city will be overturned because of their sin. The people listened to Jonah and they humbled themselves and turned from their evil ways. The Lord saw what they had done and had compassion for them.

\section{Micah}

A vision of Jerusalem and Samaria was given to Micah of Moresheth by the Lord during the reign of the Judean kings Jotham, Ahaz, and Hezekiah.

Jacobs transgressions caused the Lord to split the clouds and descend from heaven to destroy the idols in Samaria and force the people into exile. In the last days the Lords temple will reign over all other mountains, and the word of the Lord will flow out from Jerusalem so that many will know the path to God. The Enemies of Israel will strike the king down, but from Bethlehem will come a ruler over the nation. He will be a shepherd over his flock and the house of the Lord will be abandoned until the shepherd is born. 
The Lord asks not for sacrifices and burnt offerings to atone for Israel's sin, a river of oil will not suffice; what the lord requires of his people is for them to act justly, and walk humbly with the Lord.

\section{Nahum}

The vision of God as it appeared to Nahum the Elkoshite.

The shields of Israel drip red with blood and its daughters' morn their losses. The Lord is slow to anger but his vengeance falls upon those who displease him. The Lord is a fortress, a refuge from all that is evil and he will restore the vine after it has been destroyed.

\section{Habakkuk}

Habakkuk questioned the Lord asking why he does not save his people when violence confronts them and why he tolerates destruction and allows his law to be defiled. The Lord appeared to Habakkuk and revealed to him a vision of what lies ahead.

In time, the Lord will raise the Babylonians against Zion and they will destroy the Holy temple. They are retched people who swarm the land and devourer all that stands; they will arrive like a desert wind ravaging the tents of the Israelites and executing the house of the Lord. Habakkuk questioned why the Lord would strike down the Israelites with such a viol nation. The Lord assured Habakkuk that because the Babylonians built their nation of stolen plunder their captors will soon out number the kingdom and they will overcome their grief.

\section{Zephaniah}

The word of the Lord was given to Zephaniah son of Cushi, during the reign of Josiah son of Amon and king of Judah.

Everything that resides on the earth will be swept away, men and animals on dry land and in the sea will not be spared. The Lords hand will fall on Jerusalem and Judah and every remnant of Baal will be destroyed. The day of the Lord is near, and the princes and kings will be punished for filling the Lords temple with violence and deceit. The Israelites will walk like blind because of their sin and they shall fall to the trumpets that overtake their fortified walls. Before the inevitable wrath reached Zion the Lord commanded the Israelites to humble themselves and fall down to the Lord, those who do will be spared and God will return them to the remnant of Israel and they will have no fear.

\section{Haggai}

The word of the Lord was given to Zerubbabel, the governor of Judah and Josiah the high priest through the prophet Haggai. 
The Lord requested the Israelites to draw wood down from the mountain to build a house for the Lord and the Lord will be with them. The twenty-forth day of the sixth month of the King Darus' second year of reign the Lord's temple begun its resurrection.

\section{Zechariah}

The Word of the Lord fell upon the prophet Zechariah on the eighth month of the second year of King Darius' reign.

A man riding a red horse appeared in front of Zechariah, when he asked the Lord who the man was the Lord answered and said the man and the red, brown and white horses that were with him were sent by God to circle the earth and report to the angel that they have found peace among the nations. Then they have done so the Lord will return to Zion with mercy and forgive the people for their forefathers' deviations. The Lord told the prophet that Jerusalem shall require no wall because the Lord will be a burning wall that protects the city.

The hand of Zerubbabel shall lay the stone of the temple and when he is finished you will know the Lord is with you. Before the prophet was a flying scroll, like a plague it destroyed the timbers and stones of every thief's house. From heaven descended four spirits riding bronze chariots directed toward the four corners of the earth. The Lord commanded the prophet Zechariah to make a crown of silver and gold from the exiles of Babylon and place it on the head of Joshua, the high priest. Zion will be blessed and the people on the land will shine like jewels in a crown, they will burn against their enemies and the Lord will destroy anyone who faces Judah. The prophets will be silenced and the Lord will reign over the house of Israel and all nations of the earth.

\section{Malachi}

The Word of the Lord shall be great among all the nations and it was given the prophet Malachi.

The priests have defiled the Lords name; they burn useless offerings in the temple. May the doors of the Gods holy temple be sealed, because the priests do not honor and love the Lord. The priests are the messengers of the Lord, but their teachings have caused the people to stumble and because of this they will be humiliated. The Lord will send a messenger of the covenant, he will be like a refiner's fire and he shall purify the Levites.

The day is near when the people will return to the Lord and the Lord will return to his people. The Lord will send the prophet Elijah who will turn the hearts of the people to their father and the father will embrace his house. 


\section{Appendix B}

\section{New Testament}

\section{Matthew}

Beginning with Abraham and Isaac the genealogy of Jesus is traced fourteen generations to David the King of Israel. The fourteen generations after King David the Israelites were forced into exile, and fourteen generations following their return to Jerusalem and Judah Jesus was born to Joseph, son of Jacob and his wife Mary (Qur'an: Sura 2:253 where no mention is made of Joseph).

An angel of the Lord appeared to Joseph and told him to take Mary as his wife; the angel said she was blessed with the Holy Spirit and will give birth to a child of the Lord. Magi traveling toward Jerusalem saw a star appear in heaven above Bethlehem, Judea. When the Magi arrived at the Lord's house they asked where the prophesized child, born king of the Jews was. King Herod was disturbed by the Magi's news and demanded to know where the child was born, he ordered the Magi to follow the star until they found the child. The men did as the King commanded and when they found Jesus in Bethlehem they worshiped him and gave him gifts of gold and incense. Again an angel appeared to Joseph and told him to escape with the child to Egypt until Herod the king was dead. When Herod learned that the Magi defied him he was angered and ordered the sons of Bethlehem to be slain. Following the death of Herod Joseph, Mary and Jesus returned from Egypt to Nazareth in the region of Galilee.

Along the Jordan River John the Baptist preached repentance, he warned the people that the kingdom of heaven was near. The people confessed their sins and John baptized them in the river. Jesus went to the Jordan to be baptized (Qur'an: Sura 2:138) and when John saw him he said that he is not worthy to baptize him, but Jesus insisted. When John touched Jesus with the water the clouds opened, heaven descended like a dove and a voice was heard saying: "This is my Son, whom I love; with him I am well pleased." (Matthew 3:17)

After Jesus was tempted by the devil for forty days he went to the Sea of Galilee because he heard that John was imprisoned. Along the Sea he found his brother Andrew and Peter casting their nets, Jesus asked them to join him and together they would fish for men. Jesus and his disciples began teaching in synagogues and healing the ill throughout Judah. The people gathered around Jesus and he told them that the poor shall be rich in heaven and those who morn will be blessed, the peacemakers shall be called sons of God and they are the salt of the earth and the light of the world. Jesus told the Jews that he was not sent to abolish the Law of Moses but to fulfill what the prophets have dreamed. Jesus taught the people to be righteous beyond the teachers of the Law and the Pharisees and when they prayed to the Lord they were to say: Our father in heaven, hallowed be your name, your kingdom come, your will be done on earth as it is in heaven. Give us this day our daily bread. Forgive us our debts, as we also have forgiven our debtors. And lead us not into temptation, but deliver us from the evil one, for yours is the kingdom the power and the glory forever, Amen." (Matthew 6:9-13)

Jesus sent his twelve disciples (Peter, Andrew, James, John, Philip, Bartholomew, Thomas, Matthew, James, Thaddaeus, simon, and Judas Iscariot.) out to preach the good news to the lost 
sheep of Israel, he warned them he is sending them out among the wolves, and they are to be shrewd as snakes and innocent like doves. Before the head of John the Baptist was taken Jesus told the Pharisees and the Sadducees that, John was the prophesized Elijah.

Jesus asked his disciples who they thought he was, and they answered the Christ. Jesus told them that he must travel to Jerusalem where he will suffer greatly before the priests and be crucified, but in three days he will rise again. When Jesus and the disciples arrived in Jerusalem they made preparations for the Passover. Jesus went to the temple were he spoke in metaphors, he told the Jews that he will destroy the temple of the Lord and raise it again in three days. When Jesus returned to the disciples he washed their feet and told them that Judas Iscariot will deceive him. Jesus took bread and wine and gave it to the disciples, he said that the bread and wine was his body and blood and they were to consume it in remembrance of him.

Judas Iscariot marked Jesus with a kiss and the priests arrested him and took him to Pilate the governor they asked Pilate to crucify him. Judas Iscariot could not bare the guilt and threw the silver coins into the temple and hanged himself. Simon of Cyrene and Jesus carried his cross to Golgotha, a crown of thorns was placed on Jesus' head and a sign denoting the King of the Jews was nailed above his head. Jesus was crucified and the curtain in the temple was torn and the dead were raised. Jesus was taken from the cross and Joseph buried him in a cave not far from his cross. The cave was sealed with a stone and three days passed, after the Sabbath Mary and Mary Magdalene went to the tomb where an angel from heaven moved the stone, the woman entered the tomb but Jesus was not inside. They were on their way to tell the disciples when Jesus appeared to them and told them that he will meet his brothers in Galilee. Jesus commanded his disciples to travel among the nations and baptize the people in the name of the Father and of the Son and of the Holy Spirit and he will be with them to the end of the age.

\section{Mark}

The prophet Isaiah wrote: "I will send my messenger ahead of you, who will prepare your way" (Torah: Malachi 3:1) "a voice of one calling in the desert, 'prepare the way for the Lord, make straight paths for him." (Torah: Isaiah 40:3) From out of the desert John baptized in the River Jordan, he called on the people to repent and told them "After me will come one more powerful then I, the thongs of whose sandals I am not worthy to stoop down and untie. I baptize you with water, but he will baptize you with the Holy Spirit" (Mark 1:1-8)

Before John was imprisoned Jesus came from Nazareth to the Jordan River and he was baptized by John, heaven tore open and the Spirit descended on him like a dove (Qur'an: Sura 2:253). For forty days Jesus remained in the desert while the devil tested him, he then went to gather his Apostles and they preached and healed several people throughout Galilee. Jesus and the Apostles were along the waters edge, the people who came to see Jesus became so numerous that he climbed into a boat and continued teaching from the lake. Jesus taught the people by parables he said: "A farmer went out to sow his seed. As he was scattering the seed, some fell along the path, and the birds came and ate it up. Some fell on rocky places, where it did not have much soil. It sprang up quickly, because the soil was shallow. But when the sun came up, the plants were scorched, and they withered because they had no root. Other seed fell among thorns, which grew 
up and choked the plants, so that they did not bear grain. Still other seed fell on good soil. It came up, grew and produced a crop, some multiplying thirty, some sixty, some a hundred times."

After the people had left and he was alone with the Apostles they asked him about the parable and Jesus told them: "Don't you understand this parable? How then will you understand any parable? The farmer sows the word. Some people are like seed along the path, where the word is sown. As soon as they hear it, Satan comes and takes away the word that was sown in them. Others, like seed sown on rocky places, hear the word and at once receive it with joy. But since they have no root, they last only a short time. When trouble or persecution comes because of the word, they quickly fall away. Still others, like seed sown among thorns, hear the word; but the worries of this life, the deceitfulness of wealth and the desires for other things come in and choke the word, making it unfruitful. Others, like seed sown on good soil, hear the word, accept it, and produce a crop—some thirty, some sixty, some a hundred times what was sown." (Mark 4:3-8)

When Jesus was finished explaining he told them several more parables: "This is what the kingdom of God is like. A man scatters seed on the ground. Night and day, whether he sleeps or gets up, the seed sprouts and grows, though he does not know how. All by itself the soil produces grain-first the stalk, then the head, then the full kernel in the head. As soon as the grain is ripe, he puts the sickle to it, because the harvest has come." (Mark 4:13-20)

"What shall we say the kingdom of God is like, or what parable shall we use to describe it? It is like a mustard seed, which is the smallest of all seeds on earth. Yet when planted, it grows and becomes the largest of all garden plants, with such big branches that the birds can perch in its shade." (Mark 4:26-29) When Jesus finished teaching he sat alone with the disciples and interpreted the parables for them.

After Jesus had been teaching a teacher of the Law approached him and asked which of the commandments was the most important? And Jesus replied: "The most important one, is this: Hear, O Israel: The Lord our God, the Lord is one. Love the Lord your God with all your heart and with all your soul and with all your mind and with all your strength. The second is this: Love your neighbor as yourself. There is no commandment greater than these." (Mark 12:29-31)

Jesus told the people that the end was near but not even the angels in heaven knew the day and the hour, he told them to keep watch for no one knows when the owner of the house shall return. Then Jesus along with his disciples celebrated the Passover, he informed them that they would betray him and he would be killed but it was necessary to fulfill the Lords command. Then Jesus gave the Apostles bread and wine in remembrance of him. Jesus was soon arrested and put before Pilate and he was sentenced to death on a cross. Moments before Jesus took his last breath he cried: "Eloi, Eloi, lama sabachthani"--which means, "My God, My God, why have you forsaken me." (Mark 15:34) Jesus was buried in a tomb along side Golgotha. Three days after Jesus suffered on the cross Mary and Mary Magdalene went to his tomb but he had risen.

\section{Luke}

During the reign of Herod, King of Judah, among the priestly division of Abijah was the priest Zechariah. His wife had not yet had a child when the angel Gabriel appeared to Zechariah and 
said that your wife will give birth to John and the Lord will favor him. Not long after Gabriel appeared in Nazareth to Joseph, a descendant of David and his virgin wife Mary and said that Mary will also give birth. The child was to be called Jesus and he will be the Son of the Most High, and reign over the house of Jacob.

Caesar Augustus ordered that a census be taken throughout the Roman world, because Joseph was from the house of David, he and Mary setout for Bethlehem to be registered. While in Bethlehem Mary gave birth to Jesus, because he was the first born he was taken to Jerusalem to the temple, where Simeon blessed him and told Joseph and Mary that he will be a light to the gentiles and glorious in the house of Israel.

They returned to Nazareth and Jesus lived there until the fifteenth year of Tiberius Caesar's reign. Herod was tetrarch of Galilee and Pontus Pilate was governor of Judah when John began preaching repentance and baptizing in the Jordan River. The people questioned if John the Baptist was the Christ, and John told them that one will follow him and he will baptize not with water but with fire and the Holy Spirit.

Before John rebuked Herod and was imprisoned, Jesus arrived at the Jordan River. The clouds were torn and a voice descended from heaven when John baptized Jesus. The Spirit lead Jesus into the desert were he was tempted by the devil for forty days, and then to the synagogues of Galilee where he taught the people. While he was teaching at the Sea of Galilee he saw Simon, a fisherman. Simon had worked all day but had collected no fish, when Jesus told him to cast his nets. When Simon retracted the nets they tore from the weight of all the fish and Jesus told Simon that he will now be a fisher of men.

Jesus went to pray on the mountainside and when he returned he called on his twelve Apostles, Simon whom he named Peter, Andrew his brother, James, John, Philip, Bartholomew, Matthew, Thomas, James, Simon and Judas Iscariot, they gathered and Jesus taught them the beatitudes. Jesus and his disciples continued to minister and heal the people throughout Judah, when they arrived in Nain Jesus encountered a funeral procession, he touched the dead boy and his life was restored. Then Jesus sent out his Apostles to preach the gospel and heal the people, during that time Jesus told several parables and performed many miracles.

Jesus and the Apostles setout for Jerusalem, he told his disciples that he would be betrayed there. Jesus arrived at the temple and rebuked the people for making God's house of prayer into a den of robbers. Judas Iscariot agreed to hand Jesus over to the priests who wanted to arrest Jesus. Jesus and the Apostles prepared for the Passover meal and when they were finished Judas identified Jesus with a kiss and the chief priest restrained him.

The priests took Jesus before Pilate the governor; who found Jesus had done nothing wrong so he sent him to King Herod. Herod sent Jesus back to Pilate who wanted to release him, but the people insisted that he be put to death. Simon of Cyrene carried the cross behind Jesus who was crucified between to criminals. Jesus prayed for the people and told God that they know not what they are doing. The dead body of Jesus was taken off the cross, wrapped in linen, buried in a tomb that was sealed with a stone. On the morning after the Sabbath Mary and Mary Magdalene went to the tomb, they found that the stone had been rolled back and two men with garments like lighting stood before them. They asked the woman: "why do you look for the living among the 
dead?" (Luke 24:5) Then Jesus appeared to the eleven Apostles (Judas Iscariot killed himself because of his gilt) in Jerusalem, and told them what was written in the scriptures, he blessed them and then ascended to heaven.

John

"In the beginning was the Word, and the Word was with God, and the Word was God. He was with God in the beginning. Through him all things were made; without him nothing was made that has been made. In him was life, and that life was the light of all people. The light shines in the darkness, and the darkness has not overcome it... The Word became flesh and made his dwelling among us. We have seen his glory, the glory of the one and only [Son], who came from the Father, full of grace and truth." (John1 1-14)

From Jerusalem came priests and Levites to question John the Baptist, who told them that he was not the Christ. The priests refused to believe that he was just an ordinary man so John told them: "I am the voice of one calling in the desert, 'Make straight the way for the Lord' (Isaiah 40:3)." (John1 1-23) John told them that a Lamb of God exists before them and the priests saw him when Jesus came to the Jordan River. God spoke to John and confirmed that Jesus was the Son of God, the messiah.

Jesus gathered his disciples and they set out for Jerusalem, when they arrived at the temple Jesus found merchants selling sheep and doves and trading money. Jesus was displeased and rebuked the merchants driving them out of the Lords house. The merchants questioned Jesus' authority to do such a thing and he answered: "Destroy this temple and I will raise it again in three days." The Jews disbelieved him and said it took them forty years to build the temple, but after Jesus had risen from the dead they understood Jesus' metaphor and knew it was his body that he spoke of.

The disciples and Jesus went to the Sea of Galilee, after Jesus fed the five-thousand people who came to hear him teach from only five loaves of bread and two fish, he told them that he was the bread of God who came from heaven and he who eats of this bread shall never hunger unto eternity.

While in Judah for the Feast of Tabernacles Jesus went to the Mount of Olives, there the Pharisees had an adulterous woman, hoping to trap Jesus they asked him what they should do with her. The law says that she should be stoned, and Jesus said let the one with no sin cast the first stone. Not one Pharisee was able to condemn her, Jesus wrote her sin in the sand where it could be washed away, and she was forgiven.

Jesus and the disciples returned to Jerusalem for the Passover, upon his arrival to the city a great crowd of people gathered to welcome the King of Israel, they waved palm branches and sang: "Hosanna! Blessed is he who comes in the name of the Lord! Blessed is the king of Israel!" (John 12:13) Jesus washed the feet of his disciples and fed them bread and wine while he told them what the days ahead would bring. Jesus prayed for himself, for his disciples and for all believers, and then he was arrested and sentenced to be crucified. Jesus died on the cross an innocent man and rose three days later to speak with his disciples. Jesus told them that the father sent him, and now he is sending his disciples to receive the Holy Spirit and forgive the people of their sins. 
Jesus appeared to Peter who had denied him three times before his death and asked Peter three times if he loved him, Peter answered "Lord, you know all things; you know that I Love you." (John 21:17) Then Jesus asked Peter to feed his sheep and told him that his death would glorify God.

\section{Acts (Acts of the Apostles)}

The Apostles returned from the Mount of Olives to Jerusalem, they prayed along with Mary the mother of Jesus and his brothers. Matthias joined the disciples and continued their apostolic ministry. On the day of Pentecost the Holy Spirit dwelled among the Apostles and the Word of God was spoken in the tongue of Jews from every nation under heaven. Peter urged the people to repent and be baptized in the name of Jesus Christ for the forgiveness of their sins, and he promised them that they would receive the gift of the Holy Spirit.

The believers were one in heart and mind, they shared their possessions and there were no needy persons among them. Those who owned land took the sales form their land and placed it at the feet of the Apostles, who distributed it to all those who had little. The believers would meet at Solomon's Colonnade and the people would bring the sick into the streets hoping to fall under Peter's passing shadow so they might be healed. Apostles blessed many before they were arrested and imprisoned by the Sadducees, but an angel of the Lord freed them and requested they preach in the temple courts. The high priest and the elders arrived to question the Apostles and they were furious at what they heard and wanted them dead, but a Pharisee and teacher of the law named Gamaliel pleaded with the high priest. Gamaliel said that if the Apostles teachings are of human origin it will undoubtedly fail, but if it is from God there is nothing you can do to restrain it. The high priest agreed and the Apostles were freed.

Stephen spoke before the Sanhedrin and told them to accept the Holy Spirit; he reminded them that the Prophets had said that the Lord does not live in houses made from men, heaven is his throne. On that day persecution broke out on the church at Jerusalem and Saul had Stephen stoned to death, but heaven opened for Stephen and he saw Jesus at the right hand of God. The Apostles scattered across the land and Saul followed, destroying the church house by house. While on his way to Damascus a light from heaven surrounded Saul and a voice asked why he was persecuting him. Saul asked who the voice was and Jesus said it was he, and he told Saul to enter the city and wait. The lord spoke to Ananias and told him to find Saul from Tarsus and restore his sight, because he is my chosen instrument to deliver the Lord's name to the Gentiles, their kings and the house of Israel. Saul was baptized and gathered with the Apostles in Damascus where he preached in the synagogues that Jesus is the Son of God. Saul returned to Jerusalem and preached there, when his life was threatened by Grecian Jews he was taken to Caesarea and he departed for Tarsus.

Throughout Judah, Galilee and Samaria the church strengthened and Peter brought the Word of God to the Gentiles and baptized them. Not long after King Herod had James put to death, and Peter was imprisoned, but the Lord sent an angel who opened the door for Peter.

Saul, Barnabas and John sailed to Cyprus and they proclaimed the Word of God, in Salamis, Perga, Attalia, Pisidian Antioch, Iconium, Lycaonian, Lystra, Derbe. After parting with Barnabas 
and John, Paul along with Silas continued preaching in the regions of Phrygia, Galatia, Syria and Cilicia. Paul had a vision about Macedonia so along with Silas and Timothy they preached throughout Macedonia and Phipolis, Apollonia, Thessalonica and Athens. After Athens, Paul went to Corinth and then to Cenchrea and Ephesus, where he stayed for three years until he went to Jerusalem. Paul narrowly escaped imprisonment in Jerusalem and he stood trial before King Agrippa in Caesarea before he set sail for Rome to stand in the court of Caesar. When Paul arrived in Rome he preached under guard to the Jews and anyone who asked of him.

\section{Romans}

The book of Romans is a letter written by the Apostle Paul to the church in Rome.

"Paul, a servant of Christ Jesus, called to be an apostle and set apart for the gospel of God-the gospel he promised beforehand through his prophets in the Holy Scriptures regarding his Son, who as to his earthly life was a descendant of David, and who through the Spirit of holiness was appointed the Son of God in power by his resurrection from the dead: Jesus Christ our Lord. Through him we received grace and apostleship to call all the Gentiles to faith and obedience for his name's sake. And you also are among those Gentiles who are called to belong to Jesus Christ."

"To all in Rome who are loved by God and called to be his holy people: Grace and peace to you from God our Father and from the Lord Jesus Christ." (Romans 1:1-7)

Paul writes to the Romans that salvation has been granted by God through the Lord Jesus Christ for both Jews and Gentiles alike, and they shall live by faith. Circumcision is meaningless if one does not obey the law, and if one obeys the law is it not like he is circumcised? God's kindness leads to repentance therefore do not pass judgments on others. The invisible God has laid wrath upon ungodly behavior and those who are senseless, faithless, heartless and ruthless.

Paul reminds the Jews that their forefather Abraham was not credited for his works but his faith in the Lord. Therefore the Israelites have peace with God because we have been justified through faith. Paul tells the Roman church that God demonstrated his love through Christ Jesus; he sacrificed his son who was innocent for our trespasses. "Shall we go on sinning so that grace may increase? By no means! We are those who have died to sin; how can we live in it any longer? Or don't you know that all of us who were baptized into Christ Jesus were baptized into his death? We were therefore buried with him through baptism into death in order that, just as Christ was raised from the dead through the glory of the Father, we too may live a new life." (Romans 6:1-4) We have become free from sin but slaves to God, the wages of $\sin$ is death but the blessing of God is eternal life through Jesus Christ.

Paul encourages the Romans to offer their bodies as a living sacrifices to the Lord as an act of worship, those who are in Christ form one body of several members. Be faithful in prayer and share with God's people in need, pray for those who persecute you and rejoice with those who love God so through one heart you may praise the Lord. 
The Letter to the Romans is ended when Paul tells them that he is convinced that they, his brothers in Rome, are righteous and complete with knowledge and they will teach one another. Following the work Paul is engaged with in Jerusalem along with the saints, he hopes to visit Rome on his path to Spain. And finally Paul passes greetings from the numerous churches of Christ.

\section{Corinthians}

The book of 1 Corinthians is the first letter written by the Apostle Paul to the church he established in Corinth.

"Grace and peace to you from God our father and the Lord Jesus Christ." (1 Corinthians 1:3)

Paul writes that he thanks God for the church in Corinth; he knows that they have been blessed with knowledge and the spirit of the Lord. However, Paul is disappointed to have heard while in Ephesus that division has formed from within the church. Some say they follow Paul, some Apollos, some Cephas, and yet others say Jesus Christ. Paul tells them that Christ is not divided and Paul did not die on a cross for their sins, they were baptized into the name of Jesus Christ and it is he that endures forever. Paul reminds the Corinthians that when he taught them he proclaimed the news of Jesus Christ the risen Lord and God's power through the Holy Spirit. Paul says that he simply planted a seed and God made it grow into a church.

Paul then continues to teach the Corinthians, about Christian marriage, disputes among believers, sexual immortality, food sacrificed to idols, and the obligations of an Apostle of Christ. Paul warns the church that although our forefathers stood under the cloud of God and passed through the sea with Moses, the Lord was displeased with them for their lack of faith and evil desires and he destroyed many of them and scattered the remainder across the earth. Abstain from idolatry and partake in the cup that is the Lords blood, the loaf of bread that is the body of Christ unites us. You can not sit at both the Lord's Table and that of the demons.

Paul instructs the Corinthians on proper worship, suggesting that when the believers congregate they should have hymns, words of instruction, a revelation or interpretation in order to develop the church. Paul concludes his letter by reiterating the gospel that he preached to them earlier regarding the significance of the death and resurrection of Jesus Christ. Adding that he will stay with the Corinthians at the end of his journey through Macedonia.

\section{Corinthians}

The book of 2 Corinthians is a letter that followed the Apostle Paul's first which was met with certain criticism by the church in Corinth.

"Grace and peace to you from God our father and the Lord Jesus Christ." (2 Corinthians 1:2)

Paul appeals to the church and asks them not to lose heart, and be blinded as to not see the gospel of their age. It is through God's mercy that we have the ministry and the light of the gospel 
and the glory of Jesus is the image of God. Our treasure is enclosed in jars of clay and inside the believers so that the life of Jesus may be revealed in man.

Paul concludes his letter by encouraging perfection among the faithful, he urges them to be one in mind and the peace and love of the Lord Jesus will surround them.

\section{Galatians}

The book of Galatians is a letter written by the Apostle Paul to the churches established in Galatia.

"Grace and peace to you from God our Father and the Lord Jesus Christ, who gave himself for our sins to rescue us from the present evil age, according to the will of our God and Father, to whom be glory for ever and ever. Amen." (Galatians 1: 3-5)

Paul writes in his letter to the Galatians that he is upset that they have turned to another gospel and questions why they have done such a thing, knowing what the Lord has revealed to them. Paul told them that he disagreed with peter regarding gentile circumcision, and man is not justified by observing the law but through faith. Paul argues that he has died through the Law so that he may live for God. "I have been crucified with Christ and I no longer live, but Christ lives in me. The life I now live in the body, I live by faith in the Son of God, who loved me and gave himself for me. I do not set aside the grace of God, for if righteousness could be gained through the law, Christ died for nothing!" (Galatians 2:20-21)

Through faith in Jesus Christ we are all Sons of God, Paul writes to the gentiles who were slaves to false gods before the Lord made himself known to them. Jesus Christ has freed us through faith, which is expressed in love. Therefore love your neighbor as yourself and you will inherit the Kingdom of Heaven.

\section{Ephesians}

The book of Ephesians is a letter written by the Apostle Paul to the saints in Ephesus.

"Praise be to the God and Father of our Lord Jesus Christ, who has blessed us in the heavenly realms with every spiritual blessing in Christ. For he chose us in him before the creation of the world to be holy and blameless in his sight. In love he predestined us for adoption to sonship through Jesus Christ, in accordance with his pleasure and will-to the praise of his glorious grace, which he has freely given us in the One he loves." (Ephesians 1:3-6)

Paul describes to the saints that redemption was gained through the blood of Jesus Christ and the forgiveness of sins is in accordance with God's grace. It is God who is rich in mercy and he made dead men, those who followed the ways of the world and followed earthly rulers alive through their faith in Jesus Christ.

The mystery of the Lord was made known to Paul through revelation, this mystery was not released to earlier generation as the Holy Spirit has granted to the Apostles and the prophets. Paul writes that Gentiles will become one body with Israel and share the grace of God. "For you 
were once darkness, but now you are light in the Lord. Live as children of light (for the fruit of the light consists in all goodness, righteousness and truth)." (Ephesians 5:8-9)

Paul instructs the Ephesians on Christian relations between, Husbands and their Wives, Children and their Parents and Slaves and their Masters always treating the other with grace and love as you are treated by God the father.

\section{Philippians}

The book of Philippians is a letter written by the Apostle Paul to the saints, overseers and deacons in Philippi.

"Grace and peace to you from God our Father and the Lord Jesus Christ. I thank my God every time I remember you. In all my prayers for all of you, I always pray with joy because of your partnership in the gospel from the first day until now, being confident of this, that he who began a good work in you will carry it on to completion until the day of Christ Jesus." (Philippians 1:2-5)

Paul requests those at Philippi to mimic Jesus Christ's humility, and learn from his life. Do not act on vain desires but consider others above yourself and concern yourself with them. God lowered himself to be man and not any man, but a servant. He gave his Son to death, on a cross, and he exalted him in heaven.

Paul writes of his desire to know Jesus and to share in his suffering, to become like him in death and attain the resurrection. The citizenship of the believer resides in heaven, and we wait for our savior the Lord Jesus Christ.

"Rejoice in the Lord always. I will say it again: Rejoice! Let your gentleness be evident to all. The Lord is near. Do not be anxious about anything, but in every situation, by prayer and petition, with thanksgiving, present your requests to God. And the peace of God, which transcends all understanding, will guard your hearts and your minds in Christ Jesus." (Philippians 4:4-7)

\section{Colossians}

The book of Colossians is a letter written by the Apostle Paul to the brothers in Christ in Colosse.

"The Son is the image of the invisible God, the firstborn over all creation. For in him all things were created: things in heaven and on earth, visible and invisible, whether thrones or powers or rulers or authorities; all things have been created through him and for him. He is before all things, and in him all things hold together. And he is the head of the body, the church; he is the beginning and the firstborn from among the dead, so that in everything he might have the supremacy. For God was pleased to have all his fullness dwell in him, and through him to reconcile to himself all things, whether things on earth or things in heaven, by making peace through his blood, shed on the cross." (Colossians 1:15-20) 
Paul describes his labor for the church, and proclaims that his desire to reveal the mystery of God the father and his Son Jesus Christ to those who once resided in the dark but know shine in the light of the Lord comes from the Lord. Paul teaches the brothers in Colosse about proper Christian living and where their thoughts should be paid.

"Set your minds on things above, not on earthly things. For you died, and your life is now hidden with Christ in God. When Christ, who is your life, appears, then you also will appear with him in glory." (Colossians 3:2-4)

\section{Thessalonians}

The book of 1 Thessalonians is the first letter written by the Apostle Paul to the church of the Thessalonians.

"For the Lord himself will come down from heaven, with a loud command, with the voice of the archangel and with the trumpet call of God, and the dead in Christ will rise first. After that, we who are still alive and are left will be caught up together with them in the clouds to meet the Lord in the air. And so we will be with the Lord forever." (1 Thessalonians 4:16-17)

Paul encourages the Thessalonians to put faith and love on as a breastplate, because God appoint us to suffer but to receive salvation thought Jesus Christ. And they are asked to prepare themselves because the day of the Lord is unknown it will creep like a thief in the night.

\section{Thessalonians}

The book of 2 Thessalonians is the second letter written by the Apostle Paul to the church of the Thessalonians.

Paul warns the Thessalonians that the day of the Lord has not yet come, it will be known when the rebellion occurs, the lawless man will be revealed when he fills the temple and proclaims himself to be god. The Lord Jesus will destroy him with his words and the splendor of his presents. The Lord has chosen the Thessalonians to be saved by the grace of God. 


\section{Appendix C}

\section{Qur’an}

\section{Sura 1 The Opening (Al-Fatiha)}

"In the name of Allah, Most Gracious, Most Merciful. Praise be to Allah, the Cherisher and Sustainer of the worlds; Most Gracious, Most Merciful; Master of the Day of Judgment. Thee do we worship, and Thine aid we seek. Show us the straight way, The way of those on whom Thou hast bestowed Thy Grace, those whose (portion) is not wrath, and who go not astray."

\section{Sura 2 The Cow (Al-Baqarah)}

In the name of Allah, the Compassionate, Most Merciful. This is the book which guides those who fear God. Those who believe in the unseen God and his revelation establish prayer and have certain faith in the Hereafter (Heaven), they will attain salvation. Those who reject faith, have been blinded, their disease of deception is known to Allah who surrounds them like a dark cloud and troughs lighting to instill fear in them. Guard yourselves against evil; for a hell fire fueled with men and stone and awaits those disbelieve the revelation. Gardens with flowing rivers giving life to fruit will be seen and tasted by the faithful, who do good in the eyes of Allah.

How is it possible for one to deny Allah who gave life to the lifeless and who will bring you to death and raise you again to Him. Allah enlightens many and confounds none but the transgressors. He has created all that there is on the earth and shaped the sky into seven heavens. Allah taught Adam the names of all that exists and Adam recited theses names to the angels. Adam was told to dwell with his wife in paradise and eat anything you choose but that which blossoms from the forbidden tree, but Satan tempted Adam and they were expelled from the garden. (Torah: Genesis 2:15-25, 3:1-24 where Satan tempts Eve) Adam repented for the wrong he had committed and God the merciful accepted his repentance.

Israel, fulfill your covenant with me and I will fulfill mine with you, hear my revelation which confirms your scriptures. Seek Allah with patients and prayer, remember we exalted you above all nations and opened the Red sea to deliver you from the land of Pharaoh. (Torah: Exodus 14:15-29) Moses was appointed for forty nights to receive the scripture and you adopted the calf. (Torah: Exodus 32) Those who rejected Allah will became inmates of hells fire, but those who repent are forgiven. Remember when Moses requested water for his people, and when his staff struck the rock a stream flowed for each of the twelve tribes. (Torah: Exodus 15:22-27, Numbers 20:5-12, 21:16-18) Jews, Christians and whoever believes in Allah to the end of days and does as he has commanded shall have no fear or regret they will be rewarded by the Lord. Moses was given the scriptures (Torah) (Torah: Exodus 20:1-18), and the Lord sent Jesus son of Mary (New Testament: Matthew 1:18-25, Luke 2:4-7) with miracles and strength of the Holy Spirit, but you reject the messengers that do not suit your desires. And when the lord sent revelation (Qur'an) which confirmed the Torah and the Gospels you knowingly rejected it. Who are the enemies of Allah, his Angels, the messengers he sent and Gabriel who reveled the Qur'an to Muhammad, 
those who do not believe the revelation he has sent. To Allah belongs the east and the west, whichever way you turn you shall find Allah.

To Allah belongs the dominion of the heavens and the earth, establish prayer and surrender yourself to Allah you shall enter the garden. Remember Abraham who was tried by

commandments of the Lord (Torah: Genesis 22:1-12) and was appointed the leader of mankind. Abraham and Ishmael raised the foundations of a house (Ka'ba at Makkah) to assemble, walk around and bow down to worship the Lord. Only the foolish will renounce the faith of Abraham, we chose him in the world and he shall be among the righteous in the hereafter. Upon the death of Jacob he asked his children 'What will you worship when I am gone?' (Sura 2:133) They responded the God of your forefathers Abraham, Ishmael and Isaac. (Torah: Genesis 16, 21:1-3)

"Say (Muslims): We believe in Allah and in that which had been revealed to us, and in that which was revealed to Abraham, Ishmael, Isaac, Jacob and the tribes, and in that which was given to Moses and Jesus, and in that which was given to the prophets from the Lord, we do not make any distinction between any of them, and to Allah we have surrendered ourselves." (Sura 2:136)

Baptism is from Allah, receive it for it is He who baptizes and He we serve. (New Testament: Matthew 3:13) When asked why the Qibla has been changed (direction of prayer shifted from Jerusalem to the Ka'ba at Makkah), answer to Allah belongs the east and the west he guides those He will to the straight path. We have seen Muhammad turn towards heaven to receive guidance form Allah, now you shall turn toward the Inviolable Sanctuary (Ka'ba at Makkah) wherever you are. "Each one (Abrahamic faith) has a direction to which he turns; therefore vie with one another in good works. Wherever you may be, Allah will bring you all together. Surely Allah is over all things." (Sura 2:148) Those who believe in Allah seek help in steadfast prayer and be patient; Allah will try your patients with fear and famine. As-Safa and al-Marwa (two small hills to the east of the Ka'ba) are among the sacred symbols of Allah and it is no sin while on the Hajj or Umra (pilgrimages) to walk between them and the Ka'ba.

"In the creation of the heavens and the earth; in the alternation of the night and day; in the sailing of ships through the ocean for the benefit of mankind; in the water which Allah sends down from the sky and with which He revives the earth after its death, and dispersing over it all kinds of beasts; in the ordinance of the winds and clouds that are driven between earth and sky: are signs for people who understand." (Sura 2:164)

Those who conceal portions of the revelation that Allah has sent shall fill their bellies with fire, and Allah will forget them on the Day of Resurrection. Righteousness is not found when you turn to the east or west but through faith in Allah, the last day, the angles, prophets and the scripture. Those who believe shall fast so you may learn self-restraint. "The month of Ramadan is that in which the Qur'an was revealed, a guidance to mankind and clear proofs of the guidance and the distinction (distinguishing right from wrong); therefore whoever of you is present in the month, he shall fast therein, and whoever is sick or upon a journey, then (he shall fast) a (like) number of other days; Allah desires not hardship for you, and (He desires) that you should complete the number and that you should exalt the greatness of Allah for His having guided you and that you may give thanks." (Sura 2:185) Eat and drink until the white thread becomes distinct and then refrain until the black thread of dusk. It is lawful for you to go onto your wives during the night of the fast, they are a garment for you as you are to them. 
Fight if you must for the sake of Allah but do not be the first to attack, God does not favor aggressors. If you are subject to an attack retaliate with a similar force, but do not fight during the sacred month or in the precinct of the Inviolable Sanctuary (Ka'ba at Makkah).

Give generously to the cause of Allah, and partake in the pilgrimages, if you are prevented, sent only offerings you can afford. Allah loves the doers of good. During the Hajj season seek the bounty of the Lord and remember He who gave you guidance on earth and life apart from hell fire in the hereafter. Do not walk in the footsteps of Satan; he is an enemy to you. Nor shall you ignore that which has been revealed to you. In the shadow of a cloud Allah will descend among all his angles and all shall be returned to him. (New Testament: Revelation 10:1, 14:14-16)

"For the disbelievers the life if this world is adorned; and thus they mock at believers. Yet those who fear Allah will be above them on the Day of Judgment. Allah gives without measure to whomsoever He will. Mankind were once one nation with one religion. And Allah sent to them prophets, to give them good news and warning, and with them he sent down the Scripture [Torah, New Testament, Qur'an] with the truth, that it might judge disputes between mankind. And only those whom (the scripture) was given differed concerning it, after clear signs had come to them, through hatred of one another. And Allah by his will guided those who believed to the truth of what they had disputed. Allah guides whom He will to the straight path. Or do you think that you will enter the garden while untouched the like of (the suffering which was endured by) those who were before you? Affliction and adversity befell them, and they were shaken as though with an earthquake, until the Messenger and those who believed along with him said: 'When will the help of Allah come?' Assuredly, the help of Allah is near." (Sura 2:212-214)

Do not marry those who do not believe (in Islam) for they will call you into the fire. If a man divorces his wife she must refrain from marring again for three months, during this time the man should contemplate if he should return to his wife. Divorce must be pronounced twice, and husbands shall let their wife go in kindness and must not retain anything they have given to their wife.

"Think of the leaders of the children of Israel, how they demanded of one of their prophets after (the death of) Moses: 'Raise up for us a king' they (their council of elders) said, (Torah: 1 Samuel 8:1-21) 'and we will fight for the cause of Allah. He replied: 'What if you refuse to fight, when ordered to do so?' 'Why should we refuse to fight for the cause of Allah, they replied. 'when we and all of our children have been driven away from our habitations? - but when they were ordered to fight, they all refused, accept a few of them. And Allah is aware of the wrongdoers. Their prophet said to them 'Allah has appointed Saul to be your king.' But they replied: 'Should he be given the kingship, when we are more deserving of it then he? (Torah: 1 Samuel 10:17-27) Besides he is not rich at all.' He said: Allah has chosen him to rule over you, and increase him in knowledge and stature. Allah gives His sovereignty to whom He will. He is All-Embracing, AllKnowing. Their prophets said to them: 'The sign of his kingship is that there shall come to you the ark wherein is peace of reassurance from your Lord, and a remnant of that which the house of Moses and the house of Aaron left behind, the angels bearing it. (Torah: 1 Samuel 4:1-10, 6:1-21, 7:1) Behold: in this shall be a sign for you, if you are believers. And when Saul marched out with his army, he said: Allah will put you to the test by means of a river: whoever, therefore, drinks from it shall not be of me, and whoever does not drink shall be of me, except him who takes a sip out of 
the hollow of his hand. But they all drank of it, except a few of them. And when he crossed it together with those who believed him, they said: 'We have no power on this day to face Goliath and his soldiers.' But those of them who knew that they would meet their Lord replied: 'Many a small company has defeated a mighty company by Allah's leave. Allah is with those who endure with patience. When they met Goliath and his soldiers they cried: 'Our Lord bestow on us steadfastness. Make our feet firm, and help us against the disbelieving people.' By Allah's will they routed them. David slew Goliath, (Torah: 1 Samuel 17:1-51) and Allah bestowed on him the Kingship and wisdom and taught him what He pleased. (Torah: 2 Samuel 2:1-7) Had Allah not defeated some by the might of others, the earth would have been utterly corrupted. But Allah is bountiful to His creatures. These are the signs of Allah. We recite them to you with truth, and most surely you are one of the messengers. Of those messengers We have exalted some above others. To some Allah spoke directly; others He raised to lofty status. We gave Jesus son of Mary clear signs, and strengthened him with the Holy Spirit." (Sura 2:246-253)

Allah is the heavens and the earth, the one living, eternal God. His throne embraces the heavens and the earth and he brings them out of darkness and into the light. Those who disbelieve shall be taken from light to dwell in the fire.

When the kingdom had been bestowed upon Abraham, Nimrod (Torah: Genesis 10:8) argued with him he clamed the Lord grants life and death, by choosing those who are slain and those who are spared. (Torah: Genesis 22:1-12) Abraham asked the Lord to restore life that that which is dead. Allah called on Abraham to slaughter four birds and distribute them among the hills, when you have fulfilled my request call upon the birds. When they return, know that Allah is mighty and wise.

"(Muhammad) it is not for you to guide them. Allah gives guidance to whom He will. Whatever good thing you spend, it is for your own soul, and you shall do so only for Allah's sake. And whatever good you spend, it will be repaid to you in full, and you will not be wronged." (Sura 2:272)

"The Messenger [Muhammad] believes in what has been revealed to him by his Lord, and so do the believers. They all believe in Allah and His angels, His scriptures and His messengers: 'We make no distinction between any of His messengers' - and they say: 'We hear and obey. Grant us your forgiveness, our Lord; to Thee is the eventual course." (Sura 2:285) 


\section{Bibliography}

Armstrong, Karen. A History of God. London: Alfred A. Knopf, Inc., 1999.

Cimok, Fatih. Hagia Spohia. Istanbul: A Turizm Yayinlari, 1995.

Finney, Paul. The Invisible God. New York: Oxford University Press, 1994.

Frye, Northrop. The Great Code. Toronto: Academic Press, 1982.

Gedal, Najib. Geometric Analysis of the Ka'ba (Al-Sharifa). Riyadh: King Saud University, 1999.

Goodenough, Erwin R. Jewish Symbols in the Greco-Roman Period. New York: Bollingen Foundation, 1964.

Gutmann, Joseph. The Dura-Europus Synagogue: a re-evaluation (1932-1992). Atlanta: Scholars Press, 1992.

Gutmann, Joseph. No Graven Images. New York: KTAV Publishing House, Inc., 1971.

Halbout Du Tanney, Dominique. Istanbul Seen By Matrajci. Istanbul: Dost Yayinlari, 1996.

Hopkins, Clark. The Discovery of Dura-Europos. New Haven: Yale University Press, 1979.

Karatani, Kojin. Architecture as Metaphor. Cambridge: MIT Press, 1995.

King, Geoffrey R. D. The Mosque of Bab al-Mardum and the Islamic building tradition. Toledo: Actas del Congreso Internacional, 1999.

Kirimtayif, Suleyman. Converted Byzantine Churches in Istanbul. Istanbul: Ege Yayinlari, 2001.

Kraeling, Carl H. The Synagogue. New Haven: Yale University Press, 1979.

Krautheimer, Richard. Early Christian and Byzantine Architecture. New York: Penguin Press, 1986.

Mainstone, Rowland. Hagia Sophia. London: Thames and Hudson, 1988.

Mark, Robert. Hagia Sophia: From the Age of Justinian to the Present. New York: Cambridge University Press, 1992.

Nasr, Seyyed Hossein. Islamic Art and Spirituality. Albany: State University of New York Press, 1987.

Pelaez del Rosal, Jesus. The Synagogue. Cordoba: Ediciones el Almendro, 2003. 
Perkins, Ann. The Art of Dura-Europos. London: Oxford University Press, 1973.

Peters, F.E. Judaism, Christianity and Islam. New Jersey: Princeton University Press, 1990.

Plato. Timaeus and Critias. New York: Penguin Books, 1977.

Rostovtzeff, M. Dura-Europos and its Art. Oxford: Clarendon Press, 1938.

The Holy Bible (NIV). Grand Rapids: Zondervan Bible Publishers, 1987.

The Holy Qur'an. Istanbul: Acar Matbaacilik Yayincilik Hizmetleri, 2002.

The Torah. New York: Henry Holt and Company, 2004.

Oxtoby, Willard. World Religions. Don Mills: Oxford University Press, 2002.

Vico, Giambattista. The New Science of Giambattista Vico. New York: Cornell University Press, 1948.

Verkerk, Dorothy. Early Medieval Bible Illumination and the Ashburnham Pentateuch. Cambridge: Cambridge University Press, 2004.

White, Michael. The Social Origins of Christian Architecture. Valley Forge: Trinity Press International, 1990.

Wischnitzer, Rachel. The Messianic Theme in the Paintings of the Dura Synagogue. Chicago: University of Chicago Press, 1948. 